
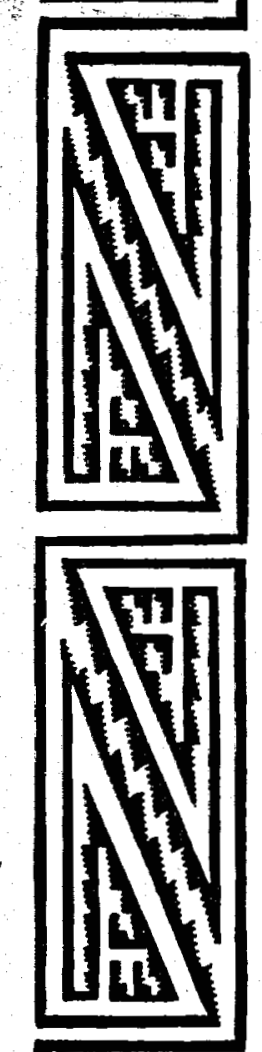

\title{
NEW MEXICO STATE UNIVERSITY CAMPUS GEOTHERMAL DEMONSTRATION PROJECT
}

\author{
Roy A. Cunniff \\ Lokesh Chaturvedi \\ Conrad Keyes
}

July 1981

New Mexico Energy Research and Development Program 


\section{DISCLAIMER}

This report was prepared as an account of work sponsored by an agency of the United States Government. Neither the United States Government nor any agency Thereof, nor any of their employees, makes any warranty, express or implied, or assumes any legal liability or responsibility for the accuracy, completeness, or usefulness of any information, apparatus, product, or process disclosed, or represents that its use would not infringe privately owned rights. Reference herein to any specific commercial product, process, or service by trade name, trademark, manufacturer, or otherwise does not necessarily constitute or imply its endorsement, recommendation, or favoring by the United States Government or any agency thereof. The views and opinions of authors expressed herein do not necessarily state or reflect those of the United States Government or any agency thereof. 


\section{DISCLAIMER}

Portions of this document may be illegible in electronic image products. Images are produced from the best available original document. 


\section{NOTICE}

This report was sponsored by the State of New Mexico. Neither the State of New Mexico nor any agency thereof, nor any of their employees makes any warranty, expressed or implied, or assumes any legal liability or responsibility for any third party's use of the results of such information, apparatus, product or process disclosed in this report, or represents that its use by such third party would not infringe privately owned rights.

The New Mexico Energy Research and Development Program is funded by the New Mexico Energy and Minerals Department, P.0. Box 2770, Santa Fe, MM 87501.

Research projects are administered by the New Mexico Energy Research and Development Institute. 


\section{NEW MEXICO STATE UNIVERSITY CAMPUS \\ $z=$ \\ GEOTHERMAL DEMONSTRATION PROJECT}

(An Engineering Construction Design and Economic Evaluation)

Final Technical Report

$(2 / 25 / 80-4 / 24 / 81)$

Principal Investigators:

Roy A. Cunniff

Physical Science Laboratory

Lokesh Chaturved1, PhD. and

Conrad Keyes, PhD.

Civil Engineering Department

New Mexico State University

Las Cruces, New Mexico 88003

\section{Authors:}

\section{Roy A. Cunniff \\ Eddie Ferguson and \\ James Archey}

Physical Science Laboratory

New Mexico S'tate University

Las Cruces, New Mexico 88003

July 1981

The work from which this material is drawn was conducted with the support of the New Mexico Energy and Minerals Department and the New Mexico Energy Institute at New Mexico State University. However, the author remains solely responsible for the content of this material. 
U 
This report provides a detailed engineering construction cost estimate and economic evaluation of low temperature geothermal energy application for the New Mexico State University Campus. Included are results from controlled experiments to acquire design data, design calculations and parameters, detailed cost estimates, and a comprehensive cost and benefit analysis.

Detailed designs are given for a system using $140-145^{\circ} \mathrm{F}$ geothermal water to displece 79 billion BTU per year of natural gas now being burned to generate steam. This savings represents a displacement of 44-46 percent of NMSU central plant natural gas consumption, or 32 to 35 percent of total NMSU natural gas consumption. The report forms the bas is for the system construction phase with work scheduled to commence in July 1981, and target on-stream date of February 1982. 


\section{ACKNOWLEDGEMENTS}

This work was carried out under an award from the New Mexico Energy and Minerals Department (END). The authors wish to thank Mr. Pat Rodriquez and Mr. George Scudella of that department for their valuable advice and assistance.

A taam of graduate and undergraduate students in the College of Engineering at NMSU supplemented the full-time staff and students in the Physical Science Laboratory in performing detailed work. The authors wish to thank Dr. Fernando Cadena who provided the intellectual insight and leadership in solving difficult problems of the gas separation and geothermal disposal operations. He wes ably assisted by Fe Padilla and Mary Clanton, who also played a key role in the overall design work, especially the Outdoor Pool. Dr. Dave Blanchard and his crew of dedicated students provided the detailed field surveys for this work. Dr. Lokesh Chaturvedi and Dr. Conrad Keyes were instrumental in the aquifer evaluation stage of this project, with key assistance from George Mitchell of the Civil.Engineering Department and Dick Lohse of the NMEI staff, with outstanding support from Charles Houghton of PSL and Larry Blount.

Our own crew of dedicated and hard working students made an immeasureable contribution. George Pringle, Don Porter, Susan Crain, Bud Be1l, Dave Cates, and Clara Pando worked long hours on the project, and made significant contributions to the engineering design calculations.

The authors especially want to thank Mrs. Candace Smit, and Darlene Bassford and her staff in the Physical Science Laboratory Word Processing Section for providing administrative support. In addition, Bud Allen and his drafting section played a key role.

A special thank you is given to Martin Whalen and the staff of the Physical Plant Department for their assistance and support. 


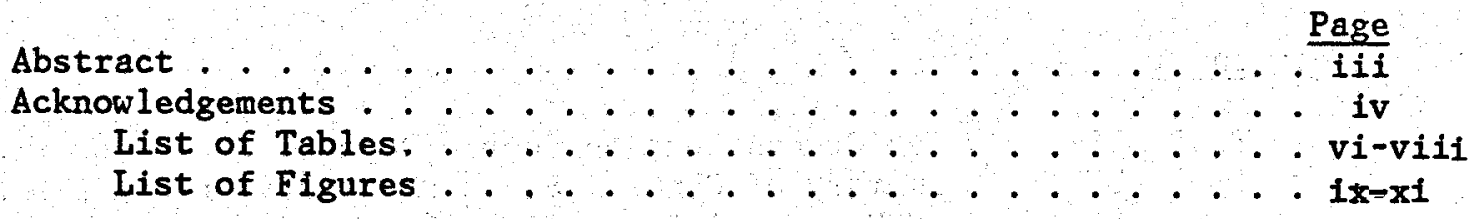

Section I: PROJECT OVERVIEW . . . . . . . . . . . . 1

Section II: NMSU NATURAL GAS CONSUMPTION AND CENTRAL BOILER

PLANT EFFICIENCY $\cdots \ldots \ldots \ldots+\cdots$

Section III: INSTRUMENTATION AND DATA ACQUISITION PLAN, AND

DATA SUMMARY . . . . . . . . . . . . . . 27

Section IV: OUTDOOR SWIMMING POOL. ............ 45

Section V: PIPELINE DESIGN. _.............. 63

Section VI: GAS SEPARATOR DESIGN . . . . . . . . . . 91

Section VII: HOT WATER STORAGE TANK DESIGN. $\ldots \ldots \ldots$

Section VIII: HEAT EXCHANGER DESIGN. . . . . . . . . . . 131

Section IX: INSTRUMENTATION AND CONTROLS DESIGN. . . . . 143

Section X: GEOTHERMAL DISPOSAL SYSTEM DESIGN. . . . . . . 153

Section XI: COST BENEFIT ANALYSIS. . . . . . . . . . 183

Section XII: FUTURE EXPANSION . . . . . . . . . . . 215

Appendices

A $\quad 48$-Hour Flow Test, Jan $81 \ldots \ldots . \ldots . . . \ldots$. . . . . .

B 48-Hour Flow Test, Dec $80 \ldots \ldots . . \ldots \ldots$...... . B-1

C Pump Performance. ................ . . . 


\section{List of Tables}

Section II

Table II-1

Table II-2

Table II-3

Table II -4

Table II -5

Table II-6

Table II -7
Las Cruces Heating Degree Days. . . . . . . . . 10

Summary of Central Steam Plant Efficiency . . . . 11 NMSU Central Steam Plant Boiler

Operating Efficiency. . . . . . . . . . . . . 12

NMSU Building Estimated Steam Usage . . . . . . . 15

Summary of NMSU Domestic Hot Water Uses . . . . . 16

Other Non-Heating Season Uses of Steam. . . . . . 19

Steam Using Equipment in Ag Building and

Biology Building. . . . . . . . . . . . 20

\section{Section III}

Table III-1

\section{Section IV}

Table IV-1

Table IV-2

Table IV-3

Table IV-4

Table IV-5

Table IV-6

\section{Section V}

Table V-1

Table V-2

Table $V-3$

Table $V-4$

Table V-5

Table V-6

Table V-7

\section{Section VI}

Table VI-1

Table VI-2

Table VI-3

Table VI -4

Table VI-5

\section{Section VII}

Table VII -1

Table VII-2

Table VII-3
Summary of Data and Measurements on

Target Buildings. . . . . . . . . . . . 31

Outdoor Pool Heating Load .... . . . . . . . 49

Outdoor Pool Design Heating Load. . . . . . . . . 50

Calculations of Outdoor Pool Heating Loads. . . . 51

Swimming Pool Weather Data. . . . . . . . . . 57

Wind Summary. . . . . . . . . . . . . . . . 60

NMSU Campus Weather Data. . . . . . . . . 62

Detailed Cost Estimates .. . . . . . . . 73

Transmission Pipeline Design Parameters . . . . . 78

Heat Loss Calculations. . . . . . . . . . . . . 80

Temperature Losses, Minimum Flow Condition. . . 83

Cost Estimates for Fittings for Transmission

Pipeline. . . . . . . . . . . . . . . . . 85

Technical Specification, Johns-Manville

TEMPTITE. . . . . . . . . . . . . . . . . . . . 87

Technical Specification, Ameron BONDSTRAND. . . 89

Gas Collection Rate Tests . . . . . . . . . 92

Geothermal Well Field Subsurface Pressures. . . . 95

Gas Composition, Separated from Liquid. . . . . . 96

Gas Composition, Dissolved in Liquid. . . . . . . 97

Maximum Estimate Gas Separation . . . . . . . 100

Summary of Hot Water Demand . . . . . . . . . 107

Hourly Peak Hot Water Demand, by Building . . . 109

Hourly Peak Hot Water Demand, by Building . . . . 110 


\section{List of Tables (cont.)}

Page

Table VII-4

Table VII-5

Section VIII

Table VIII-1

Table VIII-2

\section{Section IX}

Table IX-1

Section X

Table $X-1$

Table $X-2$

Table $X-3$

Table $X-4$

Table X-5

Table $X-6$

Table X-7

\section{Section XI}

Table XI-1

Table XI-2

Table XI-3

Table XI-4

Table XI-5

Table XI -6

Table XI-7

Table XI-8

Table XI-9

Table XI-10

Table XI-11

Table XI-12

Table XI-13

Table XI-14

Table XI-15

Table XI-16

Table XI-17

Table XI-18

Table XI-19

Table XI-20

Table XI-21
Analysis of Outdoor Pool Water. . . . . . . 133

Heat Exchangers . . . . . . . . . . . . . 135

Composite Hourly Hot Water Demand . . . . . . 111

Composite Average Hourly Hot Water Consumption. - 112

Instrumentation and Control Package

(Preliminary) . . . . . . . . . 151

Geothermal Water Quality. . . . . . . . 166

Well Water Analysis . . . . . . . . . 167

We1l Water Analysis . . . . . . . . . . 168

Well Water Analyses . . . . . . . . . . 169

Geothermal Water Analysis PG-2. . . . . . . 170

Conductivity Data, NMSU Geothermal Wells. . . . . 172

Well Data, Las Cruces Wells and Campus Wells. . 179

Total Cost of NMSU Campus Geothermal Project. . . 184

Installed Capital Equipment Cost Summary. . . . 185

Gas Separator Cost Estimate ... . . . . . 186

Hot Weter Storage Tank Cost Estimate. . . . . . . 187

Well Pump Specification and Cost Estimate . . . . 188

Pump House Cost Estimate. . . . . . . . . . . 190

Primary Heat Exchanger Cost Estimate. . . . . . 191

Equipment Building Cost Estimate. . . . . . . 192

Building Retrofit Cost. . . . . . . . . . . 193

Preliminary Cost Estimate, Water Treatment. . . 195

Projected Maintenance Significant Components. . . 198

Projected Depreciation Cost for Significant

Components. . . . . . . . . . . . . 199

Projected Annual Operating Expenses . . . . . 200

Mid Case Projections for Industrial Use Natural

Gas Prices. . . . . . . . . . . . .. . 202

Natural Gas Purchase Prices . . . . . . . . 203

Possible Price Growth Scenarios . . . . . . . . 205

Compounded Price Growth Indices . . . . . . . . 205

Possible Future Costs and Cost Savings. . . . . . 208

Possible Net Annual Surplus . . . . . . . . 209

Possible Pay-off Period . . . . . . . . . . . 211

Air Pollution Reduction . . . . . . . . . 212 


\section{List of Tables (cont.)}

\section{Section XII}

Page

Table XII-1

Future Expansion Options. . . . . . . . . . 220

Table XII-2

Future Expansion Cost \& Benefits. . . . . . . . . 221

Table XII-3

Summary of Usage, NMSU Central Plant System . . . 222

Appendix A

Table A-1

Drawdown in Observation Well, 1/25/81 . . . . A-6

Table A-2

Drawdown in Observation Well, $1 / 26 / 81$. . . . . A-7

Table A-3

Total Drawdown in Observation Well. . . . . . A-8

\section{Appendix B}

Table B-1

Pump Test Data (Drawdown in PG-1) . . . . . . . B-4

Table B-2

Pump Test Data (Drawdown in Observation Wel1). . B-5

\section{Appendix C}

None 
Section I

Figure I-1

Figure I-2

\section{Section II}

Figure II-1

Figure II -2

Figure II-3

\section{Section III}

Figure III-1

Figure III-2

Figure III-3

Figure III-4

Figure III-5

Figure III-6

Figure III-7

Figure III-8

Figure III-9

Figure III-10

Section IV

None

\section{Section V}

Figure V-1

Figure V-2

Figure V-3

Figure $V-4$

\section{Section VI}

Figure VI-1

Figure VI-2

Figure VI-3

Figure VI-4
NMSU Campus Geothermal Project. . . . . . . . 2

NMSU Campus Geothermal System . . . . . . 3
NMSU Natura1 Gas Consumption. . . . . . . . 9

Campus Natural Gas Offsets, Jan - Jun, 1980 . . . 24

Campus Natural Gas Offsets, Ju1 - Dec, $1980 \ldots 25$

Temperature/Flow Conversion Chart ... . . . 33

Regents Row Condensate Flow .......... 36

Activity Center Condensate Flow . . . . . . . 37

Rhodes, Garrett, Hamiel, Condensate Flow. . . 38

WRC Condensate Flow ............... . . 39

Corbett Condensate Flow . . . . . . . . . . 40

Garcia Hell Condensate Flow . . . . . . . . 41

Alumn1 Condensate Flow. . . . . . . ..... 4 42

PSL Condensate Flow . . . . . . . . . 43

Meat Laboratory Condensate Flow . . . . . . . 44

Geothermel Project-Map. . . . . . ... 67

Campus Geothermal Pipeline System . . . . . 70

Domestic Water Lines . . . . . . . . . . . 71

Sketch of Hot Water Distribution System .... . 79

Schematic of Gas Separator Test Fixture . . . . 94 Gas Flow Rate vs. Discharge Back

Pressure, PG-1. . . . . . . . . . . . 99

Ges Separator System. . . . . . . . . . 104

Details of Controls of Gas Separator

System. . .............................. 105

Section VII

Figure VII-1 Composite Hot Water Demand. . . . . . . . . . 113

Figure VII-2 Detailed Schematic of Hot Water Storage Tank.

With Variable Level Water Intake. . . . . . . . 121

Figure VII-3 Schematic of Hot Water Storage Tank with

Auxiliary Emergency Heater and In-line

Pressure Balancing Pump . . . . . . . . . . 122 
Figure VII-4

Figure VII-5

Figure VII-6

Figure VII-7

Figure VII-8

Figure VII-9

Figure VII-10

Figure VII-11
Details of Auxilary Heater. . . . . . . . . 123

Alumni Average Flow . ............. . 124

Pan Am Average Flow . . . . . . . . . . . . 125

WRC Average Flow. . . . . . . . . . . . . ... 125

Regents Row Average Flow. . . . . . . . . . 126

Garcia Hall Average Flow. . . . . . . . . . . . . 127

Stadium Flow 30 Oct - 10 Nov, 1980. . . . . . 128

Stadium Flow 10 Nov - 16 Nov, 1980. . . . . . . 129

\section{Section VIII}

Figure VIII-1

Figure VIII-2

Figure VIII-3

Figure VIII-3

Figure VIII-5
Heat Exchanger Specification Sheet 1. . . . . . 137

Heat Exchanger Specification Sheet 2. . . . . 138

Heat Exchanger Specification Sheet 3. . . . . . . 139

Heat Exchanger Specification Sheet 4. . . . . . . 140

Schematic of Heat Exchanger Complex . . . . . . . 141

\section{Section IX}

Figure IX-1

Planning Schematic, Instrumentation and Controls Gas Separator Complex. . . . . . . . . . 147

Figure IX-2 Planning Schematic, Instrumentation and

Figure IX-3 Controls Heat Exchanger Complex . . . . . . . . 148 Planning Schematic, Instrumentation and Controls Hot Water Storage Tank . . . . . . . . 149

\section{Section X}

Figure $X-1$

Figure $X-2$

Figure $X-3$

Figure $X-4$

Figure $X-5$

Figure $X-6$

\section{Section XI}

Figure XI-1

Figure XI-2

\section{Appendix A}

Figure $A-1$

Figure $A-2$

Figure $A-3$

Figure $A-4$
Schematic of NMSU Golf Course Well . . . . . . 157

Survey of Golf Course Well. . . . . . . . . . . . 158 Golf Course Well Temperature Gradient

Measurements. . . . . . . . . . . . . . . . . . 163

NMSU Geothermal Disposal System Schematic . . . . 174 NMSU Geothermal Disposal System with Treatment

Ponds . . . . . . . . . . . . . . . . 176

Location Map of Wells . . . . . . . . . . . 178

NMSU Campus Cost to Produce Steam, FY 1978-1980 . 207

NMSU Central Plant Gas Consumption 1979-80 vs.

Estimated Potential Geothermal Offsets. . . . . 214

Locations of NMSU Geothermal Wells. . . . . . A-5

Semi-Log Plot of Drawdown vs. Time, PG-3. . . . A-9

U vs. W(u) Curve. . . . . . . . . . . . . . A-10

Log-Log plot of Drawdown vs $r^{2} / \tau$. . . . . . . A-11 
Appendix B

Figure B-1 Drawdown vs. Time, PG-1, 12/15-17/80. . . . . . B-6

Figure $B-2$

Drawdown vs. Time, Observation Well, 12/15-17/80. B-7

Appendix C

Figure C-1 Schematic of Peerless Pump. . . . . . . . C-5

Figure C-2 Peerless Pump Performance .......... . C-6 


\section{PROJECT OVERVIEW}

This project is designed to provide heated domestic water to 12 buildings on the NMSU campus. In the process, the geothermally heated water will displace a steam-heated water system, and will reduce natural gas consumption by an estimated 78,800 mcf per year (79 billion BTU per year of heat displacement). Pay-off period for this project in 1980 costs is estimated to be 4 to 6 years, with rapidly escalating natural gas prices expected to shorten this period.

Figure $I-1$ is an overall representation of the NMSU campus, depicting the geothermal well field on the East side of the campus, and the twelve buildings to be served by the system. The geothermal water will travel approximately one and one-half miles through an insulated pipeline to a heat exchanger complex. There, part of the domestic water system will be heated, and the spent geothermal water will be piped to a disposal well. In turn, the heated domestic water will be piped through an additional one and one-half miles of insulated pipeline to the end-use buildings.

Figure $I-2$ is a schematic representation of the overall system. The designed geothermal well flow rate will be $200-250$ gallons per minute (gpm) from one of the two existing geothermal wells. These wells have been flowed tested individually at 200-250 gpm, at a temperature of 141$145^{\circ} \mathrm{F}$, and also at a combined flow rate of $400 \mathrm{gFm}$. 


\section{NMSU CAMPUS GEOTHERMAL PROJECT}

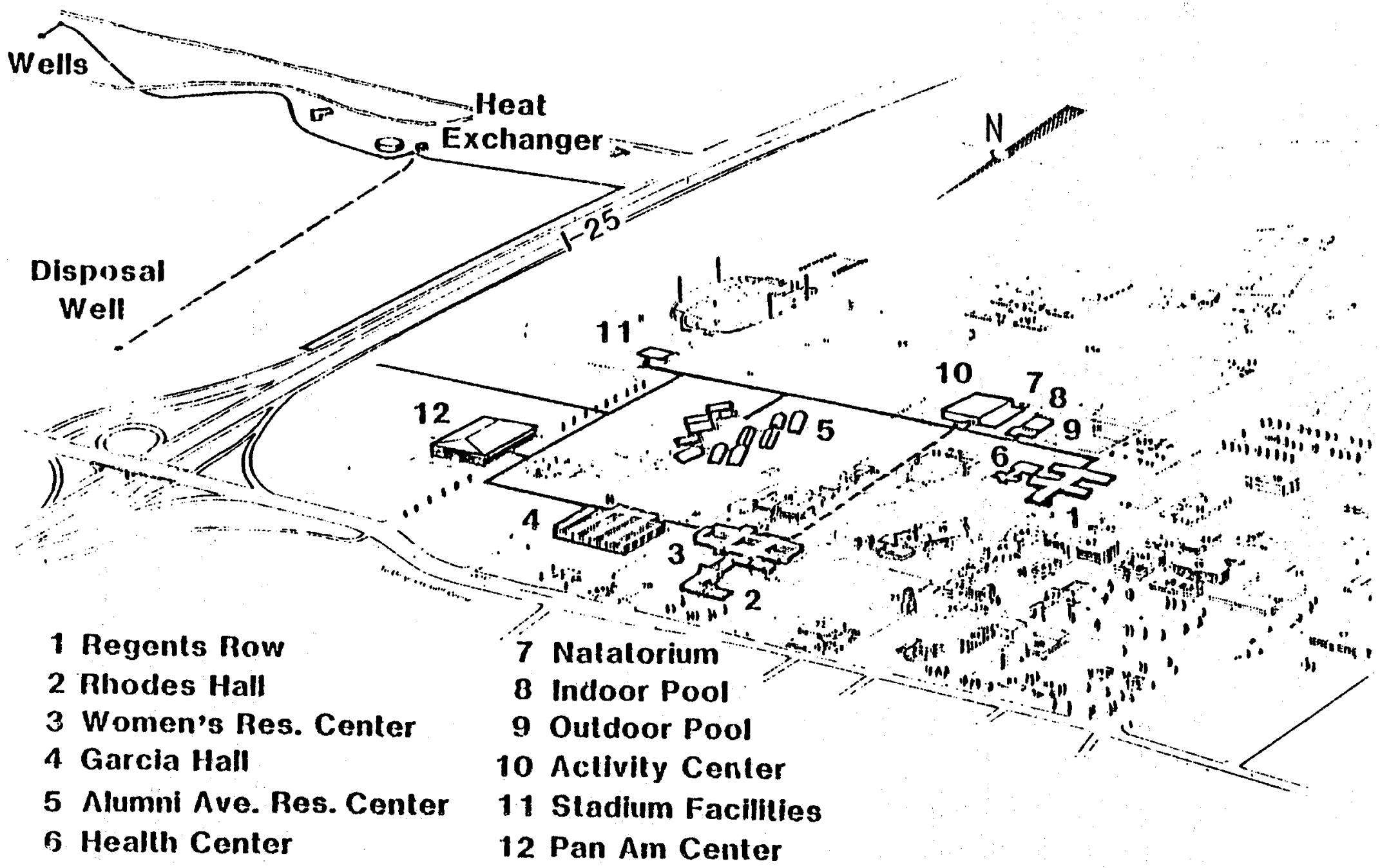

Figure I-1 


\section{NMSU CAMPUS GEOTHERMAL SYSTEM}

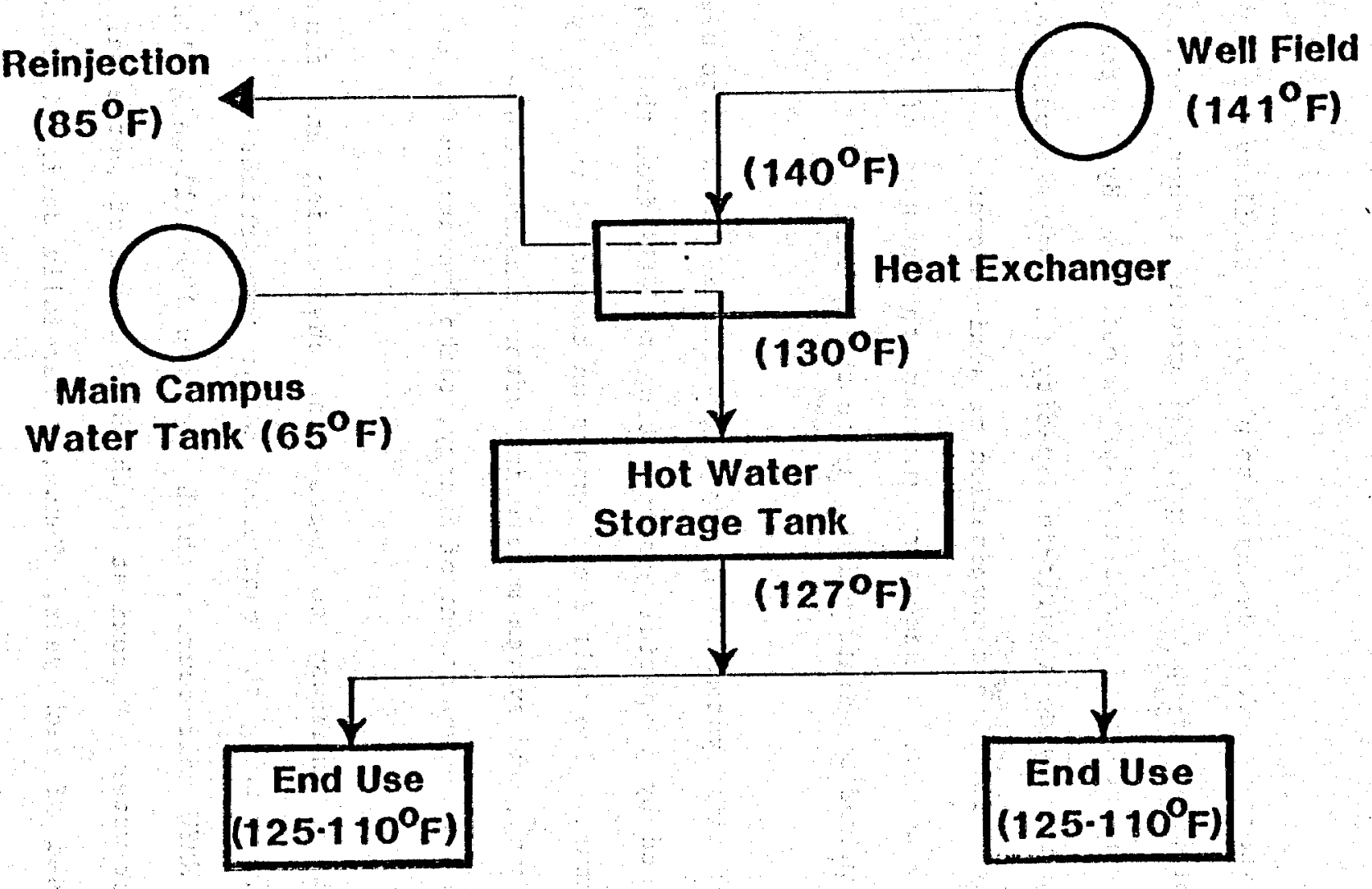

Figure I-2 
A full technical report is in preparation detailing the drilling and testing program for this well field. However, report details and conclusions for aquifer tests are contained in Appendices A and B to this report.

The hot water storage tank is designed to provide capability for peak flow of domestic hot water of up to $400 \mathrm{gpm}$, and provide a short-term storage capability in the event of temporary system outages. System components have been sized to provide a built-in capacity for future expansion. The completed system will have a combination of semi-automatic and automatic controls to reduce to a necessary minimum the number of full-time technicians required to maintain and operate the system.

Construction of this system using existing wells is scheduled to begin in July 1981, funded by a special appropriation to NMSU from the 1981 New Mexico Legislature. The well field expansion completed in January 1981, project management, and system monitoring after construction are funded by a grant from the US Department of Energy, Idaho Operations Office.

Follow-on work is underway to assess the engineering and financial implications of reusing the geothermal water for irrigation. Primary target is the NMSU golf course, which now uses 130 million gallons per year of domestic water. Approximately the same amount of geothermal water will be disposed of each year. Hence, a carefully designed series of laboratory tests and field experiments will provide data to assess cost factors and efficiency of alternative treatment methods. Concurrently, the research team will be assessing any short- or long-term potentially 
deleterious effects of the water on the golf course grass and shrubs.

Preliminary data also indicates the system could be expanded to encompass at least three other buildings, within current fund availability. The major elements of the system (pipeline, heat exchanger, and hot water storage tank) will be constructed to accommodate this early expansion, as well as providing capability for even larger future expansion. 
$\omega$

$\checkmark$ 


\section{NMSU NATURAL GAS CONSUMPTION AND CENTRAL BOILER PLANT EFFICIENCY}

\section{General}

The analysis of the NMSU natural gas consumption for generation of steam is drawn upon data available from the $66 \mathrm{th}, 67 \mathrm{th}$, and 68 th New Mexico fiscal years. These are the fiscal years from 1978 to 1979,1979 to 1980 , and 1980 to 1981 respectively. In addition data were extracted from available records concerning the efficiency of the central steam plant in the same time frames.

\section{Natural Gas Consumption}

a. The central steam plant at NMSU consumes 160,000 to 180,000 mef of natural gas per year. This gas is burned in the central boiler system to generate steam for use in the campus buildings. The central system is connected to some 50 buildings, of which 22 currently use steam only for heating in the winter time and some other institutional uses. The remaining 28 buildings require steam for both winter time heating and year round usage for domestic hot water service and for some specialized purposes. This study focused on the latter 28 buildings.

b. A major conservation program was instituted at NMSU after the oil embargo of 1973. The results of this program for the period 1978-1980 are depicted in Figure II-1. This figure supports the conclusion that a major conservation effort has resulted in significant decrease in natural gas consumption, with no loss of the essential services. The most striking evidence of this conservation program is obtained by 
comparing fiscal year 1978-1979 with fiscal year 1979-1980. It is noted that much of this decrease is the result of conservation, although some can be attributed to the warmer weather in the second year. In terms of heating degree days, as a measure of steam consumption, the winter of 1979-1980 was 2.5 per cent warmer than the previous winter. This would translate into a decreased consumption of at least 4250 mcf of natural gas. This conclusion is reinforced by comparing the results of monitoring for the next six months, which is the first part of the fiscal year 1980-81. Figure II-1 shows the three fiscal years, with the first half of the latest fiscal year, 80-81. The significance of this figure is that in spite of the increased coolness of the winter, the peak consumption is still almost 10 percent below a similar peak in the cold winter previously experienced in FY 78-79. The sharp dips in FY 79-80, and FY 80-81 in the November time frame reflect the management decision to terminate steam service to dormitories and non-essential buildings over the Christmas break for these years, and to reduce system steam pressure to $50 \mathrm{psig}$ in this low-demand period. 


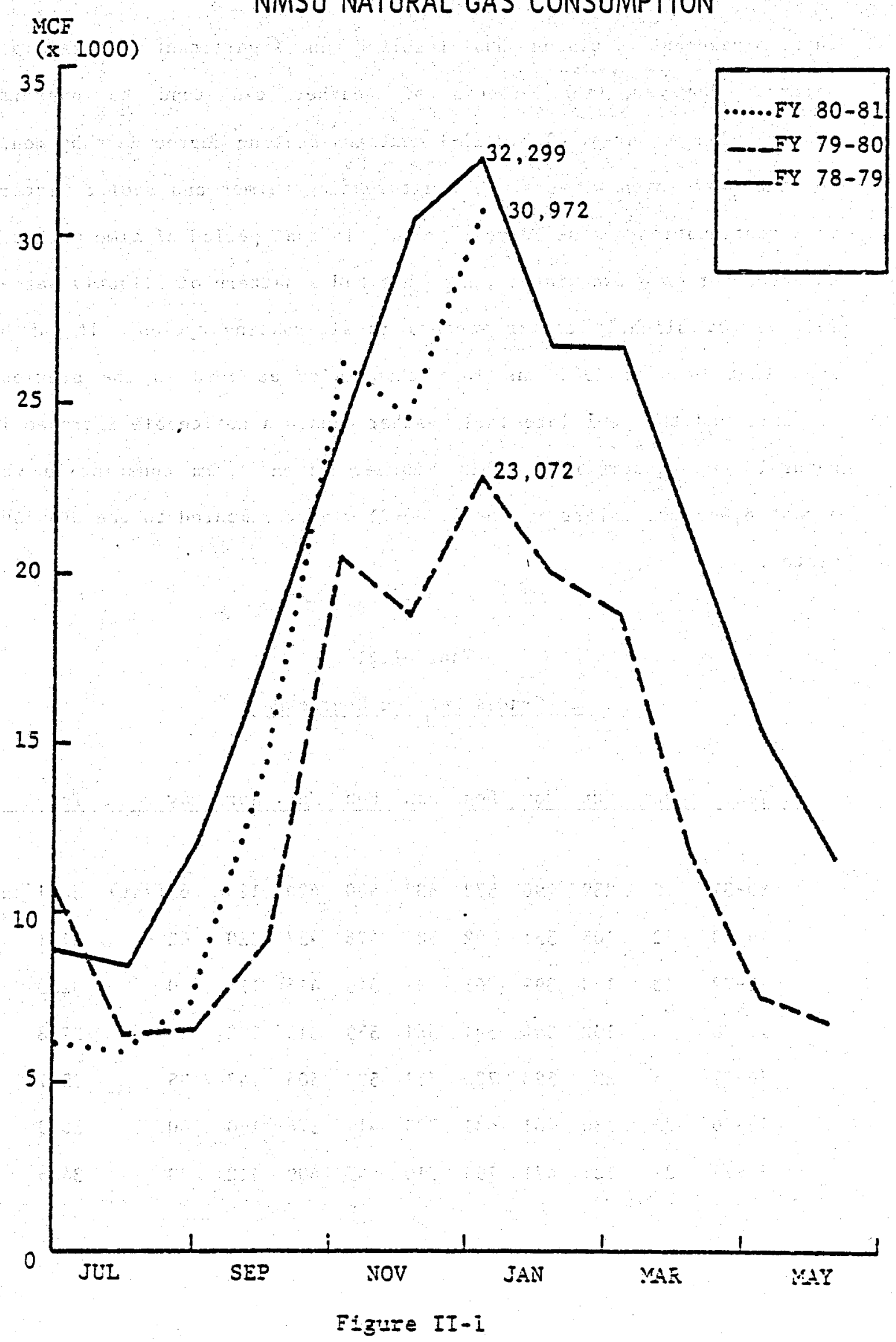


This management decision has resulted in significant natural gas savings. However, the effects of weather can tend to override conservation measures. Table II-1 contains heating degree days by month for the past seven winters. The alternating warmer and cooler winters is a continuation of the 30-year trend. In that period of time with the exception of only two winters, NMSU has had a pattern of slightly warmer followed by slightly cooler winters in alternating cycles. It can be seen that October 1980 was more than twice as cold as the previous October, and the cool late fall weather caused a noticeable increase in natural gas consumption. This weather-driven steam consumption was almost 8,000 mcf larger in the FY $80-81$ winter compared to the previous winter.

Table II-1

Las Cruces Heating Degree Days

Year Sept Oct Nov Dec Jan Feb Mar Apr May

Total

$\begin{array}{lrlllllllll}80-81 & 2 & 239 & 496 & 572 & 637 & 480 & 420 & 120 & 65 \text { (est) } & 3031 \text { (est) } \\ 79-80 & 22 & 105 & 551 & 702 & 586 & 476 & 457 & 220 & 62 & 3181 \\ 78-79 & 18 & 140 & 399 & 761 & 801 & 545 & 416 & 173 & 0 & 3253 \\ 77-78 & 0 & 102 & 384 & 591 & 661 & 559 & 319 & 122 & 50 & 2788 \\ 76-77 & 5 & 233 & 598 & 786 & 711 & 527 & 505 & 147 & 35 & 3547 \\ 75-76 & 25 & 130 & 461 & 681 & 739 & 417 & 376 & 160 & 40 & 3029 \\ 74-75 & 27 & 121 & 471 & 795 & 710 & 547 & 409 & 312 & 73 & 3465\end{array}$


c. In considering the seasonal usage of stean for 50 buildings, compared with the norm over the year of only 28 buildings with steam service connected, it would be expected that the central steam plant operating efficiency would vary from month to month. In addition, as a conservation measure, the administration also controls the steam pressure in the lines so as to reduce pressure in low demand periods and increase it in high demand periods. This is a practical engineering consideration, in that the higher pressure is required when all buildings are in service because of the need to push the steam through a much greater distance of pipeline throughout the campus. Table II-2 is a summary of 1978,1979 , and 1980 central steam plant efficiency.

Table II -2

Summary of Central Steam Plant Efficiency

YEAR HIGH LOW MONTHLY AVERAGE

$\begin{array}{llll}1978 & 89 & 77 & 81.5 \\ 1979 & 91 & 73 & 81.3 \\ 1980 & 85 & 65.6 & 77.5\end{array}$

Table II-3 provides data for each month of these years. In 1980 , the significant shift occured; the low was $65.6 \%$ and the high was $85 \%$. The trend has been toward decreasing efficiency of the central plant as attempts were made to reduce steam pressure and limit service. 
Table II-3

NMSU Central Steam Plant Boiler Operating Efficiency (\%)

\begin{tabular}{llll} 
MONTH & 1978 & $\underline{1979}$ & 1980 \\
\hline & & & \\
January & 80 & 85 & 85 \\
February & 79 & 91 & 81 \\
March & 78 & 84.3 & 78.9 \\
April & 77 & 81.9 & 79.5 \\
May & 78 & 74.6 & 70.3 \\
June & 79 & 73.0 & 65.6 \\
July & 87 & 76.9 & 76.3 \\
August & 89 & 78 & 79.5 \\
September & 83 & 77.6 & 79.5 \\
October & 83 & 79.0 & 79.9 \\
November & 86 & 84.0 & 76.5 \\
December & 80 & 83.0 & 80.0
\end{tabular}

$\begin{array}{llll}\text { Monthly Average } & 81.5 & 81.3 & 77.5\end{array}$ 
The plant was designed to have all 50 buildings operating simultaneously with higher pressure; as a consequence, when service is terminated to some buildings, and lower than designed operating pressures are used, the overall efficiency decreases. This becomes a tradeoff, then, in that the decreased efficiency necessitates larger natural gas consumption per $1000 \mathrm{lbs} / \mathrm{steam}$, whereas the higher efficiency would normally mean lower energy consumption per unit of steam (per 1000 lbs). In fact, the total decrease in steam consumption means that fuel conservation has been obtained. This decrease consumption is not as large as desired, but to obtain higher efficiencies and reduced consumption, major changes are necessary.

d. With a measure of the central boiler plant efficiency, it is possible to attain a first assumption as to the overall system efficiency. This overall efficiency would consider the efficiency of the system from the point of consumption of natural gas in the boiler to the provision of heat to the end-use buildings. It must consider not only the central boiler efficiency, but also distribution system losses throughout the system, the end use conversion efficiency in which steam is used to heat water for fan-forced systems, or hot water systems, and the overall condensate losses in the system. Precise data were not available for this system. Hence, the initial assumption was made based upon a design analysis done at the L'EGGS hosiery plant in Las Cruces. The L'EGGS plant, which is a single building, had a $70 \%$ central boiler efficiency, and overall system efficiency of $58 \%$. In considering the widely disbursed distribution at NMSU campus, it was expected that the overall system efficiency for central steam plant would range from 40 
to $60 \%$. At the outset, it was not known what factor to use, so a range of overall efficiencies was assumed ranging from 40 to 50 to $60 \%$.

In looking at the heat consumed for domestic hot water in the 12 buildings that use hot water year round, a determination was made that $40 \%$ efficiency was representative. Table II-4 depicts the natural gas used, and condensate produced for the 12 target buildings in an array of system efficiencies. The remaining 16 buildings were then analyzed to determine required steam consumption. 
Table II-4

Estimated Major Building Steam Usage

\begin{tabular}{|c|c|c|c|c|c|c|c|c|c|c|c|c|c|c|c|}
\hline FLOW & Buirnitc & $\begin{array}{l}\text { FLOW METER } \\
\text { CORRECTION }\end{array}$ & $\begin{array}{l}\text { PEAK } \\
\text { FLOW }\end{array}$ & $\begin{array}{l}\text { AVG } \\
\text { FLOW }\end{array}$ & $\begin{array}{l}\text { ADJUSTED } \\
\text { AVG FLOW }\end{array}$ & $\begin{array}{l}\text { PEAK } \\
\text { TEMP }\end{array}$ & $\begin{array}{l}\text { AVG } \\
\text { TEMP }\end{array}$ & $\begin{array}{l}\text { YEARLYY } \\
\text { USAGE }\end{array}$ & & TUSTED $\mathrm{F}$ & $\begin{array}{l}\text { NATURAI } \\
\text { ELOW }\end{array}$ & GAS OFFS & ET/YEAR & ONDENSA & \\
\hline $2^{\prime \prime}$ & $\begin{array}{l}\text { ACTIVITY } \\
\text { CENTER }\end{array}$ & +2.5 & 30 & 3 & 5.5 & 150 & 145 & 365 & 1927 & 3212 & 4818 & 0.229 & 1880 & 3133 & 4700 \\
\hline \multirow[t]{2}{*}{$1 \frac{1}{210}$} & ALIMINI & +2.0 & 75 & 16 & 18.0 & 140 & 135 & 247 & 3735 & 6224 & 9337 & 0.375 & 3081 & 5135 & 7702.5 \\
\hline & $\begin{array}{l}\text { ALIUMNI } \\
\text { SIMHAER }\end{array}$ & +2.0 & 40 & 15 & 17.0 & 140 & 133 & 85 & 1179 & 1965 & 2948 & 0.129 & 1060 & 1767 & 2650 \\
\hline $3^{14}$ & $\begin{array}{l}\text { FOOTBALL. } \\
\text { STADIUM }\end{array}$ & +6.5 & 45 & 10 & 16.5 & 140 & 140 & 120 & 1782 & 2970 & 4455 & 0.106 & 869 & 1448 & 2173 \\
\hline $2 \frac{k}{2}$ & GARCIA & +4.0 & 60 & 17 & 21.0 & 140 & 140 & 247 & 4668 & 7781 & 11671 & 0.146 & 1199 & 1998 & 2998 \\
\hline $1 \frac{1}{2}$ & PAN AM & +2.0 & 29 & 3 & 5.0 & 140 & 138 & 365 & 1599 & 2665 & 3997 & 0.0715 & 588 & 980 & 1470 \\
\hline \multirow[t]{4}{*}{$3 "$} & OUTROOR & o & 80 & 80 & 80 & 80 & 80 & 210 & 2016 & 3360 & 5040 & 0.304 & 2497 & 4162 & 6243 \\
\hline & POOL. & 0 & 200 & 200 & 200 & 80 & 80 & 210 & $(5040)$ & (8415) & $(12600)$ & $(0.760)$ & $(6243)$ & 10405 & 15608 \\
\hline & $\begin{array}{l}\text { INDOOR } \\
\text { POOL \& }\end{array}$ & 0 & $18 *$ & $18 *$ & $18 \%$ & 80 & 80 & 210 & 204 & 340 & \multicolumn{5}{|c|}{511 (Indoor included in outdoor pool) } \\
\hline & NATATORIU & o & $10 \%$ & $3^{*}$ & $3 *$ & 140 & 130 & 210 & 492 & 819 & 1229 & & & & \\
\hline
\end{tabular}

* Estimated flow 


\section{Other Hot Water Users}

a. In addition to the twelve target buildings, an inspection and analysis were performed for all other uses of steam during the non-space heating season. Key data acquired are summarized as follows:

Table II -5

Summary of NMSU Domestic Hot Water Users

$\begin{array}{cccc}\text { Type Building } & \begin{array}{c}\text { Quantity of } \\ \text { Buildings }\end{array} & \begin{array}{c}\text { Not Water Faucets } \\ \text { Hot of }\end{array} & \begin{array}{c}\text { Domestic Hot Wat } \\ \text { Temperature }\end{array} \\ \text { Dormatories } & 5 & 2,078 & 125-130^{\circ} \mathrm{F} \\ \text { Other Buildings } & \underline{7} & \underline{269} & 125-130^{\circ} \mathrm{F} \\ \quad \text { Sub-total } & 12 & 2,347 & \end{array}$

Admin. Buildings

and Classrooms

16

453

$60-135^{\circ} \mathrm{F}$

TOTALS

28

2,800

A preliminary conclusion is that the twelve target buildings represented $84 \%$ of the in-service hot water faucets, and probably at least $84 \%$ of the steam-produced hot water consumed on the NMSU Campus. These totals exclude 12 buildings which have electric water heaters, and two which contain a solar hot water system. Also of interest is that the actual temperature of the domestic hot water system in the 16 buildings ranged from $60^{\circ} \mathrm{F}$ (essentially cold water) to $104^{\circ} \mathrm{F}$ for the Agriculture building, and to $135^{\circ} \mathrm{F}$ for other buildings. Because the demand is for low temperature water, which currently requires high temperature (and costly) steam to produce, these buildings represent an attractive target for a non-steam alternative. 
With a known hot water faucet inventory, and an estimate of frequency of use of these administrative hot water systems, a major conclusion is that steam is unnecessarily being wasted in attempting to provide such limited peak and short-demand usage. Since it is necessary to provide an insulated steam line to every one of these 16 dispersed buildings, each of which uses hot water only intermittently during scheduled laboratory sessions, the use of steam for this purpose appears to be costly and ineffective. This conclusion was reinforced by the facts discovered in an attempt to measure faucet water temperature. With the exception of the Meat Lab, Biology, and Corbett Center it was necessary to let the hot water faucet run for 10-15 minutes in order to get warm water. Among other implications is that water is being wasted in an attempt to get warm water. It would appear that every building in this 16-building category would be well-served by a small 30-gallon or so electric water heater. None of the individual hot water demands was large enough to justify a steam heat exchanger.

\section{Specialized Uses of Steam}

In addition to domestic hot water service, other buildings use steam for specialized operation. These uses are summarized in the following paragraphs, and are further quantified in Table II-6.

a. The PSL building uses steam throughout the year. In the summertime, when steam provides the heating side to the double duct hot and cold system, with chilled water on the cool side, this steam is required for system balance. Wintertime usage of steam is for space heating with the cold side being ambient air. 
b. For Corbett Center the steam is required for the double duct system year around, but also for the cafeteria where it is used for a steam-operated dishwasher and for some jacketed-kettle kitchen equipment.

c. For the Meat Lab, the steam is piped to a heat exchanger, where it is used in steam coils to heat water to $180^{\circ} \mathrm{F}$ for usage in sanitary cleanup operations. Also, live steam is used in blanching operations.

d. In the biology laboratories, steam is used to operate a steam-driven still for distilling water for use in controlled experiments. This still was designed to operate at a 100 psig; when the overall system pressure is kept at $50 \mathrm{psig}$ as an economy measure, this steam still operates in a less efficient range. In fact, the central system pressure could be reduced even further to satisfy other building needs. For example PSL and Corbett systems have the steam pressure reduced to 7.5 psig for use in the building heating systems. This biology/chemistry still is the pacing factor for overall system steam pressure.

e. The steam is also used in the Agricultural building in some walk-in controlled humidity chambers. This usage is typical of steam process applications years ago when natural gas prices were a fraction of what they are today. 


\section{Other Non-Heating Season Uses of Steam}

BUILDING

Corbett Center

Biology Department

Chemistry

Agricultural Building

Plant Pathology

Botany and Entomology

Plant Pathology

\section{USES}

Steam operated dishwasher

Steam kettles

Hot water

$50 \mathrm{gpm}$ still ( $30 \mathrm{gpm}$ @ $50 \mathrm{psi}$ )

(45 gpm (a) $100 \mathrm{psi}$ )

5 autoclaves ( 7.5 psi steam)

2 dishwashers ( 7.5 psi steam)

Steam still (not in service)

2 autoclaves, 1 Barnstead still

1 autoclave, 1 with steam

cleaning hose

4 walk-in humidity chambers

1 autoclave

1 steam humidifier walk-in box

Meat Lab
Steam-fired blanching system, to scald hogs. 
Table II-7

Steam Using Equipment in Ag Building and Biology Building

\section{Agricultural Building}

4 steam humidity rooms

Room 250

Scanlon Morris (Ohio Chemical \& Surgical Equipment Company)

Madison, Wisconsin

Mod. 非420E

Ser. 非17151

Room 252

Steam humidifier for walk-in

\section{Biology}

American Sterilizer Company Erie, Penn.

Type $16 \times 24$ Dress. Sterilizer

Ser. 非 196518

Steam supply 35 to 60 lbs. $35-60$ psia

American Sterilizer Company

Type 1624 Dress.

Ser. 非 157763

Elec. KW9 $220 \mathrm{~V} 40.9$ amps $35-60$ psia

\section{Agricultural Building}

Plant Pathology

American Sterilizer Company

Type $20 \times 36$ formula sterilizer

Ser. 非194098 steam supply 35 to 60

American Sterilizer Company

Ser. 非2004450 35-60 psia

Barnstead Water Still

Model \#TD-5

Serial 非1796

American Sterilizer Company

Type $10 \times 12 \times 22$ instrument

Ser. 非196062 35-60 lbs. 


\section{Chemistry}

10 live steam outlets for heating flammable liquids

1 each Barnstead still $5 \mathrm{gal} / \mathrm{hr}$

1 Ohio Scanlon-Morris 20.0 psia sterilizer

\section{Biology}

Barnstead Mod. 非 0766

Ser. 非 490589

Oper. Pressure 33 lbs. 115V (valve)

$55 \mathrm{lbs} / \mathrm{hr}$

Barnstead Mod. \#0767

Ser. 非91264

Oper. Pressure 33 Ibs. 115V (valve)

Heinicke Instrument Co.

Hollywood, Florida

Mod. \#0108

Ser. \#08090-73

$115 / 230 \mathrm{~V}$ 


\section{Other Hot Water Use}

Total steam consumption also was estimated for those other 16 buildings which have some type of domestic hot water service provided by steam. In aggregate, these buildings have a total peak demand hot water need of not more than $60 \mathrm{gpm}$ if one-third the faucets were operated simultaneously. Even this limited use is probably an overestimate of need. The typical faucet is in a lab with one or two other faucets and the lab probably is used infrequently several times a week. Under these circumstances of limited use, the average daily consumption of these buildings in aggregate has to be less than any of the larger dorms. In considering the fact that there is practically no evening, weekend, or holiday use of these labs, the conclusion reached is that these domestic hot water systems account for not more than 2,000 to 3,000 mcf per year of natural gas consumption (or 0.8 to 1.2 percent of annual central boiler plant consumption of natural gas). Even this small amount of steam represents $\$ 8,500$ to $\$ 13,000$ per year in terms of 1980 costs, which is a small but significant target for conservation. In this regard, it is suspected that many of these hot water users originally were terminated in the conservation effort in 1975-76. Subsequently, service has been quietly restored. If a rigorous re-examination were concluded of such users, it is possible that hot water service is not essential for many of these buildings. In addition, for other buildings, such as the Agriculture building, the total load is being handled by a very inefficient steam boiler, and a more efficient electric hot water heater would provide overall cost savings. 


\section{Estimated Displaceable Steam For Hot Water Use}

In looking at these various usages of steam, estimates were made as to the total steam consumption for each of these uses. This assumption was then added to the steam consumption for hot water heat. The results of this analysis indicate that an unknown fraction of steam consumption resulted. This unknown fraction could only be additional system losses that were not otherwise identified. These unknown losses were then prorated equally across all of the various users to derive the natural gas consumption attributable to each one of the end uses. Figures II-8 and II-9 shown the results of this analysis on a month-by-month basis. Significantly, this analysis indicates that $78,000 \mathrm{mcf} / \mathrm{year}$ of natural gas are used for heating water for use in the 12 target buildings. The analysis further leads to preliminary conclusions as to what could be done for the other buildings so as to close the central steam plant for all but the heating season, which runs from approximately 15 November to 15 April each year. 


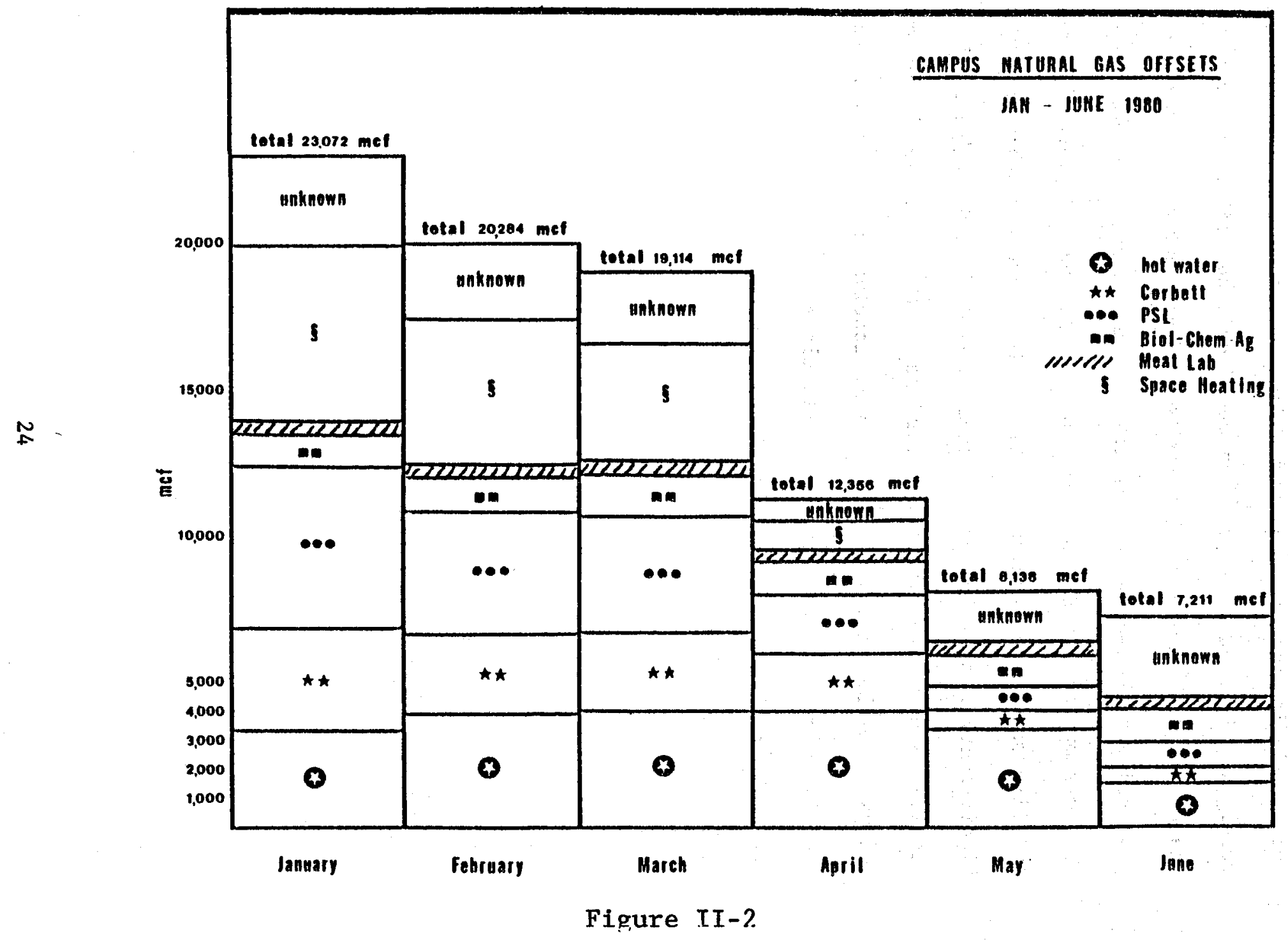




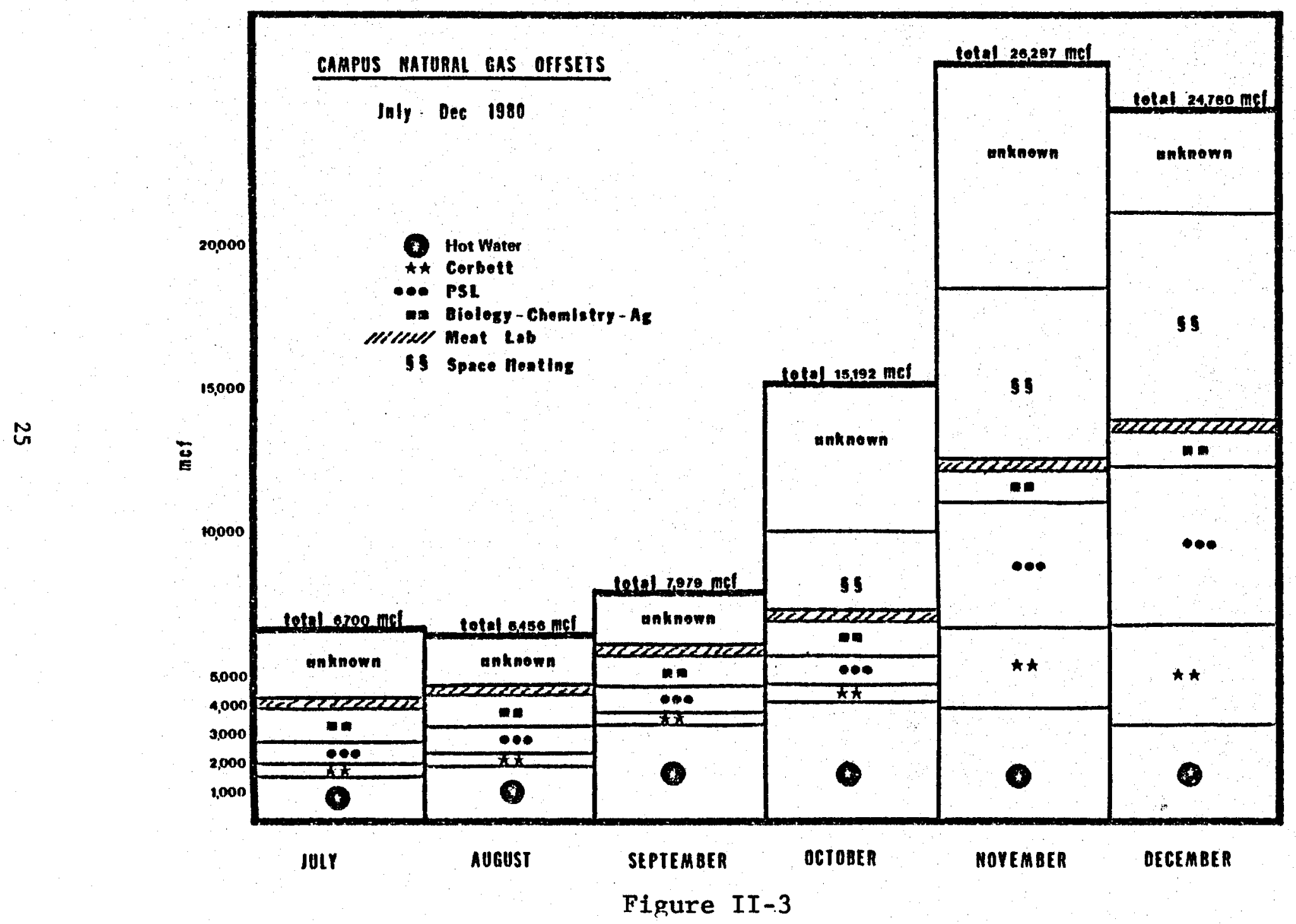


$\bullet$ 


\section{INSTRUMENTATION AND DATA ACQUISITION PLAN, AND DATA SUMMARY}

\section{General}

In order to assess the key engineering data needed for system design, a methodology was required to evaluate the kind and type of information necessary. From an overview of the central plant system, it was determined that the target buildings for the geothermal application all had a common feature -- a steam coil heat exchanger, which was connected to the fresh water system. The fresh water was heated by the steam, circulated throughout the building to end-use fixtures such as washing machines, showers, and wash basins, with a closed loop back to the heat exchanger. The existence of this particular plumbing system in each of the target buildings made it appropriate to devise an instrumentation scheme to gather the key data.

\section{Key Data Elements}

a. The geothermal heat system had to be capable of meeting the peak demand as well as the system average demand. This demand is expressed in terms of flow rate of hot water at a specific temperature. Hence, for the geothermal supplied heat, it was essential to determine the peak and average flow rate in gallons per minute of hot water, and the temperatures at which this flow rate of water was delivered.

b. From the data relative to hot water demand, it was essential that the geothermal delivery system be sized to accommodate the pressure drop resulting from friction losses in the pipeline, as well as 
providing sufficient margin for possible system expansion. Therefore, it was necessary to know the type of materials for use in this concept system.

c. In order to determine the natural gas offsets that potentially could be supplied by the geothermal system, it was essential to gain some appreciation as to the amount of steam being used for each of the target buildings. It has been previously determined that the use of central plant efficiencies was an imprecise guide to this aspect. Hence, some means was necessary to measure actual steam consumption in each of these buildings. The most readily available measure is the measurement of steam condensate flow; from this data one can derive the amount of steam in pounds per hour as used for that particular application.

\section{Data Acquisition Scheme}

a. To measure flow rates, use was made of turbine flow meters procured from Hoffer Flow Control, Inc. In order to size the flow meters for procurement, it was necessary to make a tentative estimate of the probable peak flow rates that the flow meters would experience. This assessment considered the size of the installed plumbing in each of the target buildings. The peak flow rates were estimated by using standard civil engineering factors from construction handbooks which provided estimates on average and peak flow as a function of the number of showers, wash basins, lavatories, etc. Based on these factors, a decision was made to procure three different flow meters as follows: 1 each 1.5-inch, 1 each 2-inch, and 1 each 2.5-inch. These three flow meters were supplemented by two flow meters borrowed on long term loan 
from the NASA White Sands Test Facility. Thus, the capability existed to monitor five buildings concurrently.

b. In order to translate the flow meter values into digital data and to acquire a permanent record, each flow meter required a companion flow converter. These are electronic devices which convert the pulse from the flow meter into a digital signal which can then be translated into gallons of flow.

c. Temperature transducers provide the easiest and least expensive means to acquire hot water temperatures. After some experimentation, it was determined that an accurate record could be acquired by taping the temperature transducer to the outside of exposed metal piping, and then enclosing the bond with insulation.

d. To acquire a permanent record of flow rates and temperatures, it was necessary to purchase flow and temperature recorders. With capability for five simultaneous flow measurements, and five or more temperature measurements, is was essential that at least ten flow and temperature recorders be procured. The model selected was the linear strip chart recorder manufactured by Linear Instruments.

e. Concerning values for steam condensate flow, coordination was made with the Physical Plant Department. To meet their needs and also to provide project data, a series of hot water condensate meters were purchased and installed by the Physical Plant Department. 
These hot water meters measure the flow rate of the steam condensate in each of the target buildings. In addition, for two potential target buildings, use was made of electrical mechanical recorder which merely recorded the condensate pump cycles. To determine flow rate, the capacity of the pump was measured, and then a timed interval of pump cycles could be translated into a condensate flow rate. These installations were placed in the Physical Science Laboratory and the Meat Laboratory.

\section{Monitoring}

Table III-1 provides a summary of the data and measurements that were made on each of the target buildings. The various end-use buildings were monitored for periods up to nine months in some cases. In other cases, the monitoring period was restricted to 15 to 20 days of representative use. The monitoring equipment was relocated from building to building in order to gain broad coverage as well as time-specific coverage for special events. As can be seen, the noticable omission of monitoring equipment was on Rhodes-Garrett-Hamiel dormitory. This dormitory is an older building, which is really a composite of three separate buildings each one with a separate equipment room. In order to acquire precise data it would have been necessary to install the temperature flow rate and condensate meters on each one of the three separate buildings. Because of the limited availability of test and measuring equipment, determination was made that consumption for this small dormitory could be estimated based upon a correlation between standard engineering factors and the measured data acquired on the other buildings. 
Table III-1

August 1 through Dec. 12

Days Monitored

\begin{tabular}{lccc} 
& & & \\
BUILDING & FLOW & TEMP & CONDENSATE \\
\hline Activity & 24 & 44 & 119 \\
Alumni & 35 & 35 & 134 \\
Corbett & - & - & 134 \\
Football Stadium & 23 & 43 & - \\
Garcia & 56 & 56 & 128 \\
Pan Am & 37 & 51 & 134 \\
PSL & - & - & 134 \\
Regents & 14 & 14 & 134 \\
R-G-H & - & - & 134 \\
WRC & 47 & 47 & 134 \\
Outdoor Pool & 50 & 50 & 134 \\
Indoor Pool \& Natatorium & - & - & 134 \\
\hline
\end{tabular}




\section{Hot Water Demand Temperature}

One of the key factors that was determined early in the data acquisition scheme was that the hot water system currently installed delivers water hotter than is needed for the end use applications. With the exception of the special purpose buildings (the Meat Laboratory, the cafeteria and Corbett Center), the domestic hot water can meet all human needs if a sufficient volume of water at $108^{\circ} \mathrm{F}$ can be supplied. Because of system design, and a need to maintain steam system pressure at relatively efficient levels, it was found that without exception all the target building hot water systems were being heated within the range of 115 $140^{\circ} \mathrm{F}$. Cold water then is used to cool the hot water to a comfortably warm temperature. Since the geothermal system will deliver water in the range of $115-125^{\circ} \mathrm{F}$, higher flow rates would be needed if the temperature were somewhat lower than currently supplied. Figure III-1 shows the correlation between flow rate and temperature currently demanded, and the correspondingly higher flow if lesser temperature water is supplied.

The major conclusion, however, is that the geothermal system can supply water with high enough temperature to be substituted for the uses described herein. 


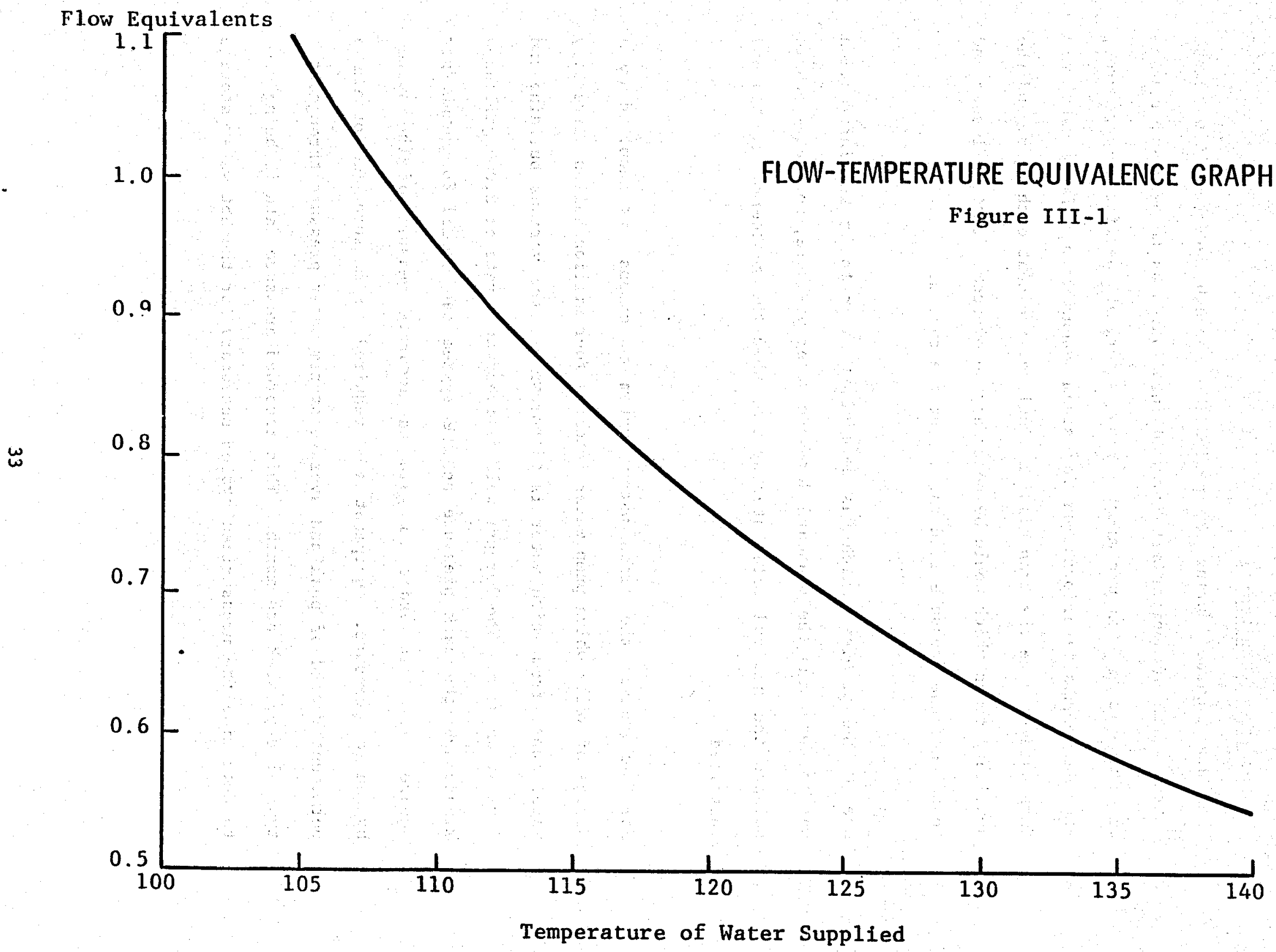




\section{Results of Monitoring}

The data acquired during the period May through December 1980 (eight months worth of monitoring) provided information as to peak and average flow rate in gallons per minute of hot water, at specific temperatures, and the requisite information for steam consumption. These data were then used to size the transmission pipeline, the heat exchanger, and the auxiliary pumps which would be necessary to overcome friction losses and to balance the pressure load throughout the system.

One of the problems which was determined later to be key information was to determine the standard domestic water pressure, so that we could balance the hot and cold water systems when the geothermal system was installed.

For background, the fresh water system on campus is supplied by a series of wells which pump water into the four million gallon university water tank, from which water is withdrawn for the various building and irrigation uses. The largest well delivers at a rate of 2,000 gallons a minute and the back pressure on the system can exceed 80 pounds per square inch. In order to gain an accurate measure of the system hydraulic pressure, equipment was required to measure and obtain a permanent record of peak and average system water pressure throughout a typical day, week and month. This recorded pressure data is being used to determine the pressurized system necessary for the hot water storage tank. 


\section{Data Records}

Figures III-2 through III-10 depict the record of steam condensate (hence steam) in each of the target buildings for which steam condensate was measured. These figures highlight some of the major problems associated with totalizing hot water meters. The meters measure and record (totalize) the flow of condensed steam at temperatures in the range of $180-210^{\circ} \mathrm{F}$. If the condensate trap in the steam line "chatters" or spasms, live steam can flash through the condensate line, and damage the flow meter, or cause erroneous readings.

In addition, the very high temperatures can result in errorous data, or premature meter failure. As a result of such problems, a relatively accurate record was obtained only during the non-heating season. However, when steam pressure was increased to $100 \mathrm{psig}$ at the start of the heating season, most of the hot water meters (condensate meters) recorded misleading or inaccurate data.

Key data acquired from the comparison instrumentation (cold water flow meters and temperature recorders) is summarized and charted in Section VII of this report, which contains design calculations for the hot water storage tank which is designed to provide a load-leveling effect for peak and minimum flow conditions. 


\section{REGENTS ROW CONDENSATE FLOW}

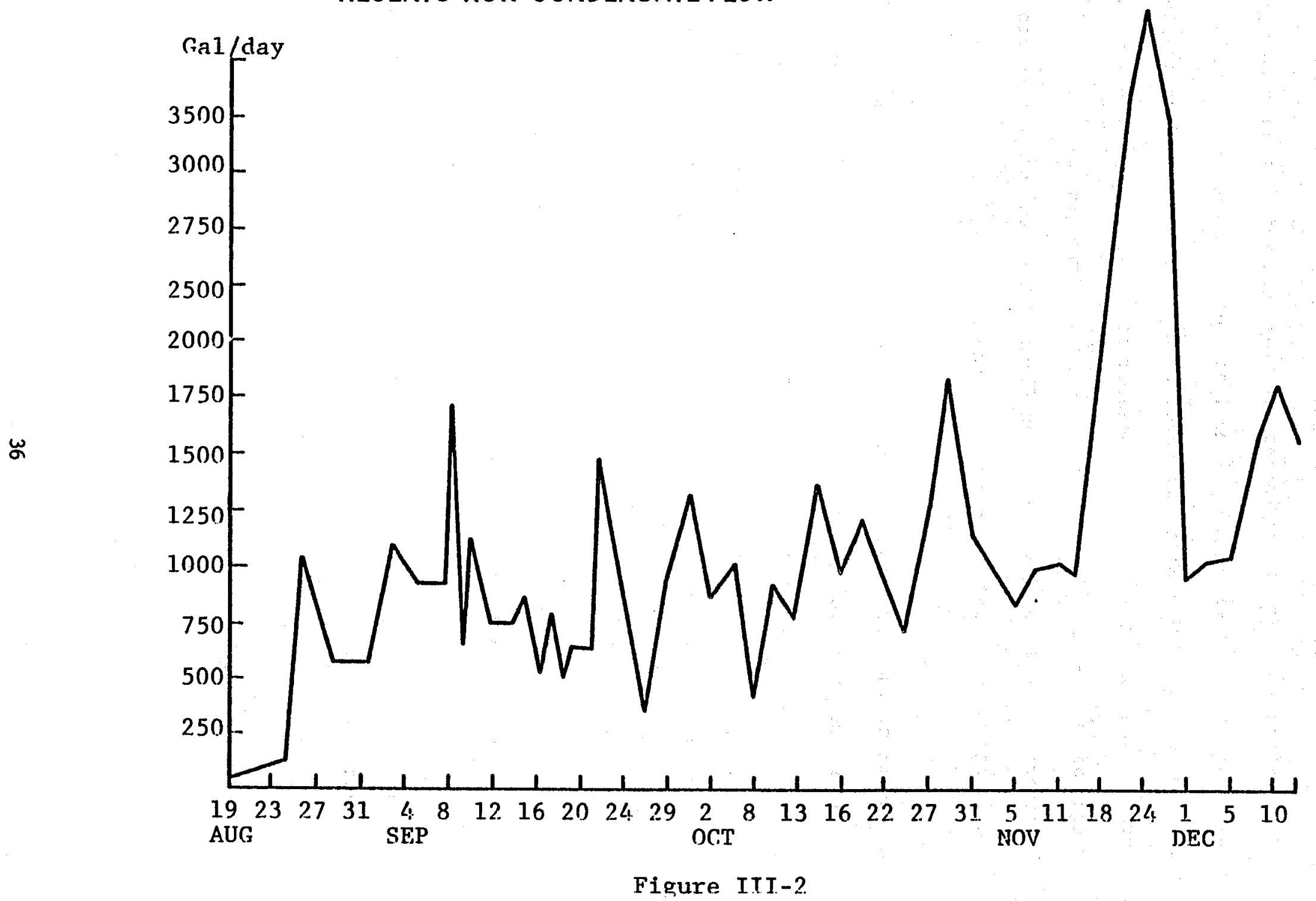


$\stackrel{\omega}{\omega}$

\section{ACTIVITY CENTER CONDENSATE FLOW}

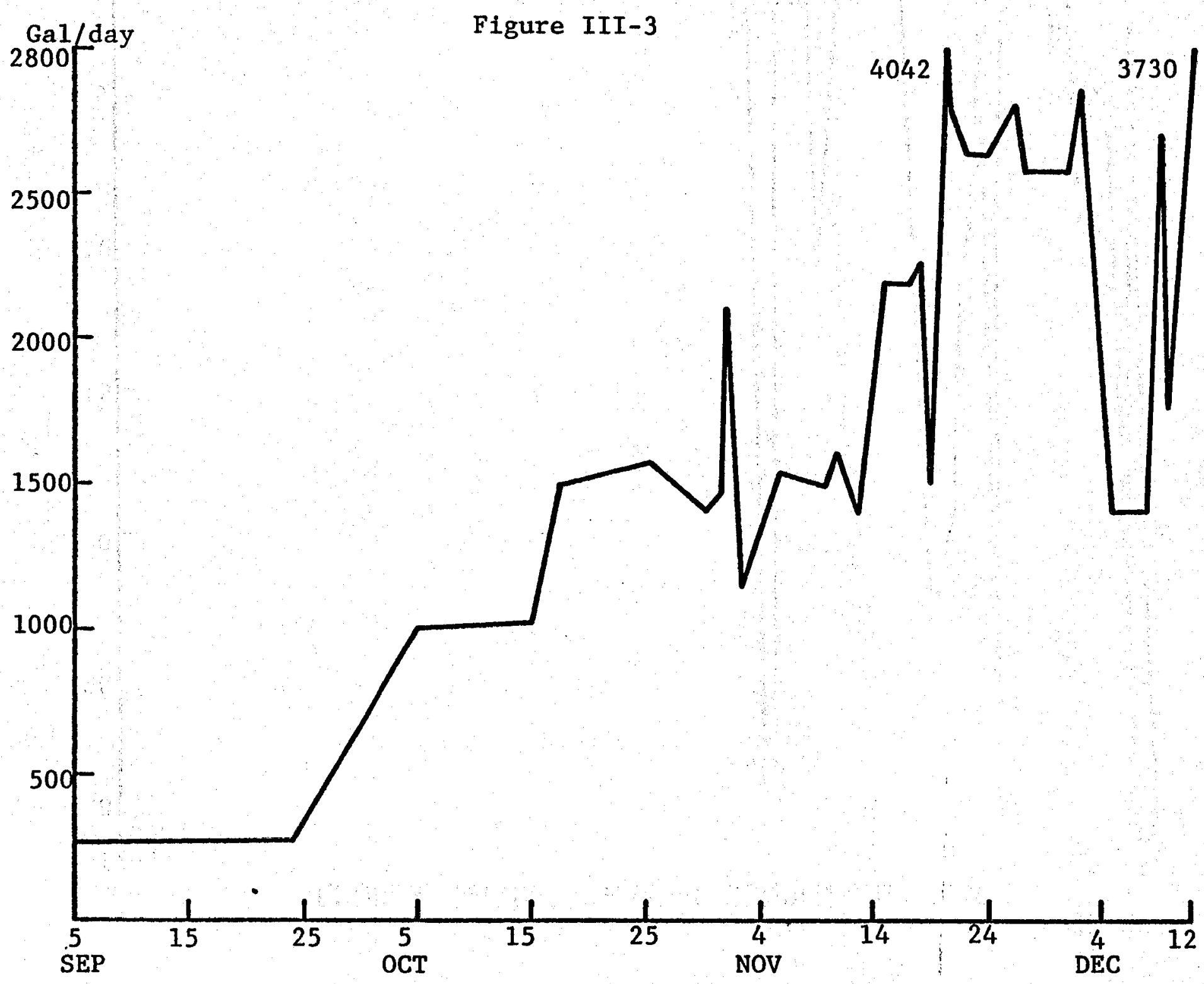


RHODES, GARRETT, HAMIEL CONDENSATE FLOW

$\omega_{\infty}$

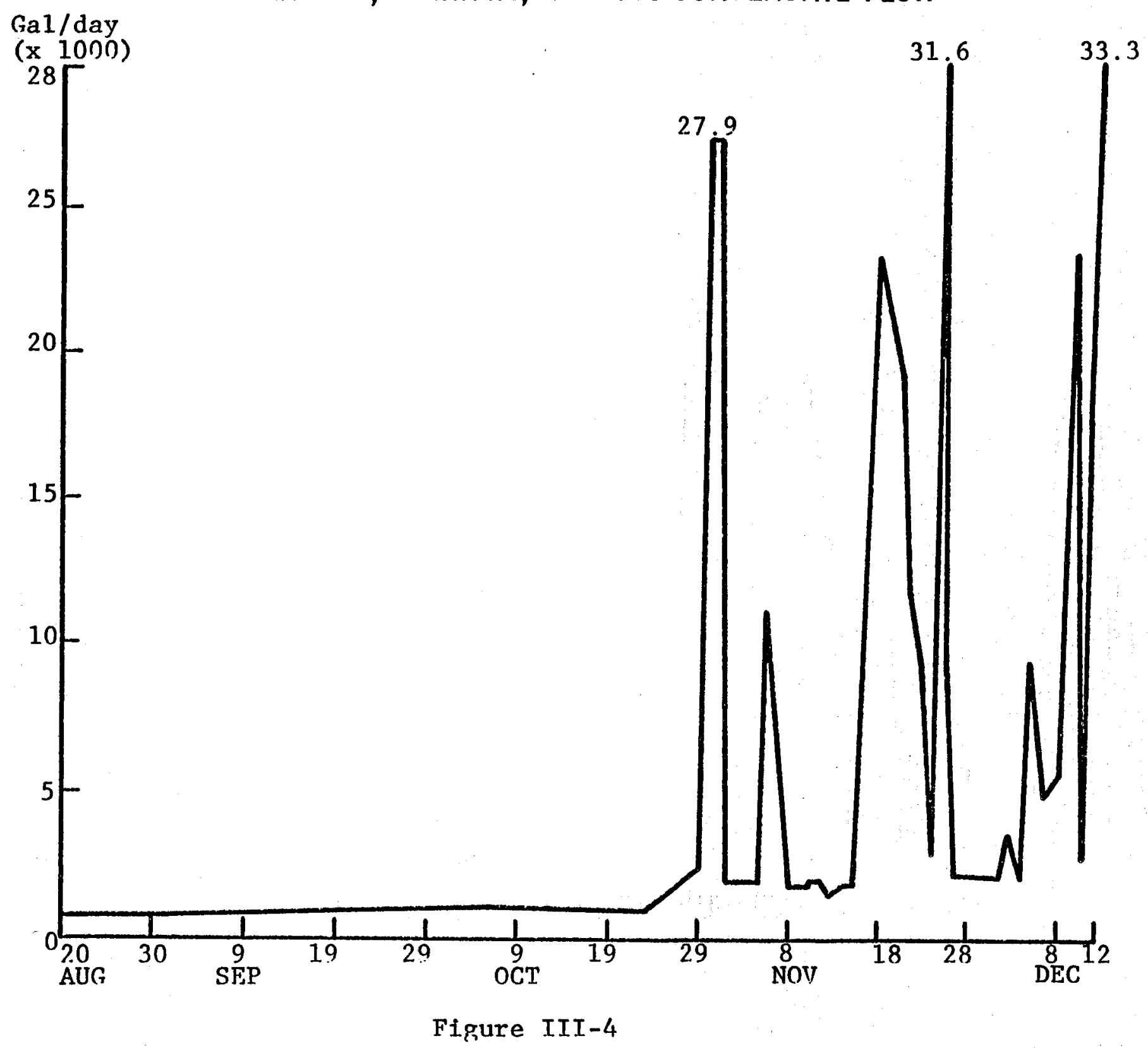




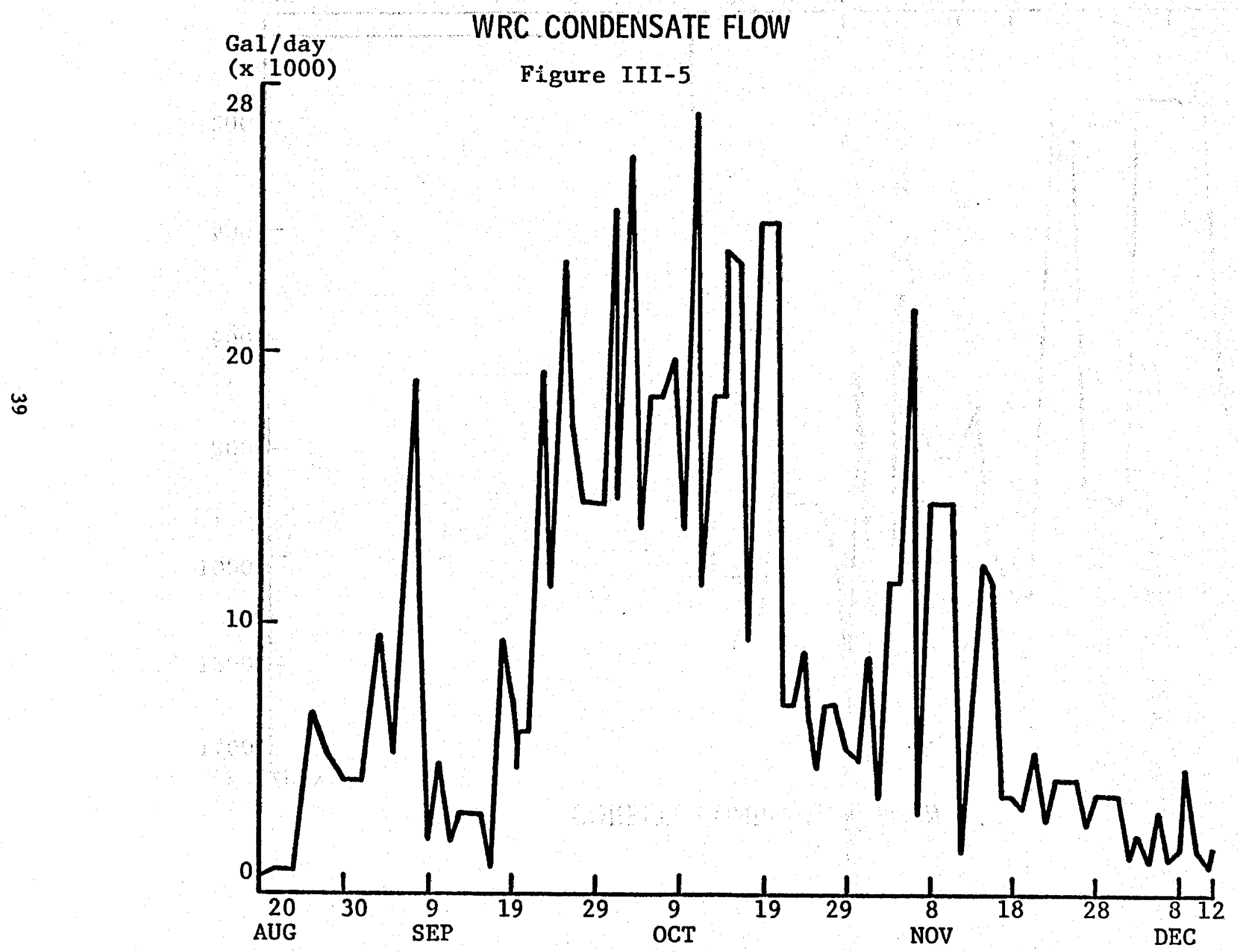




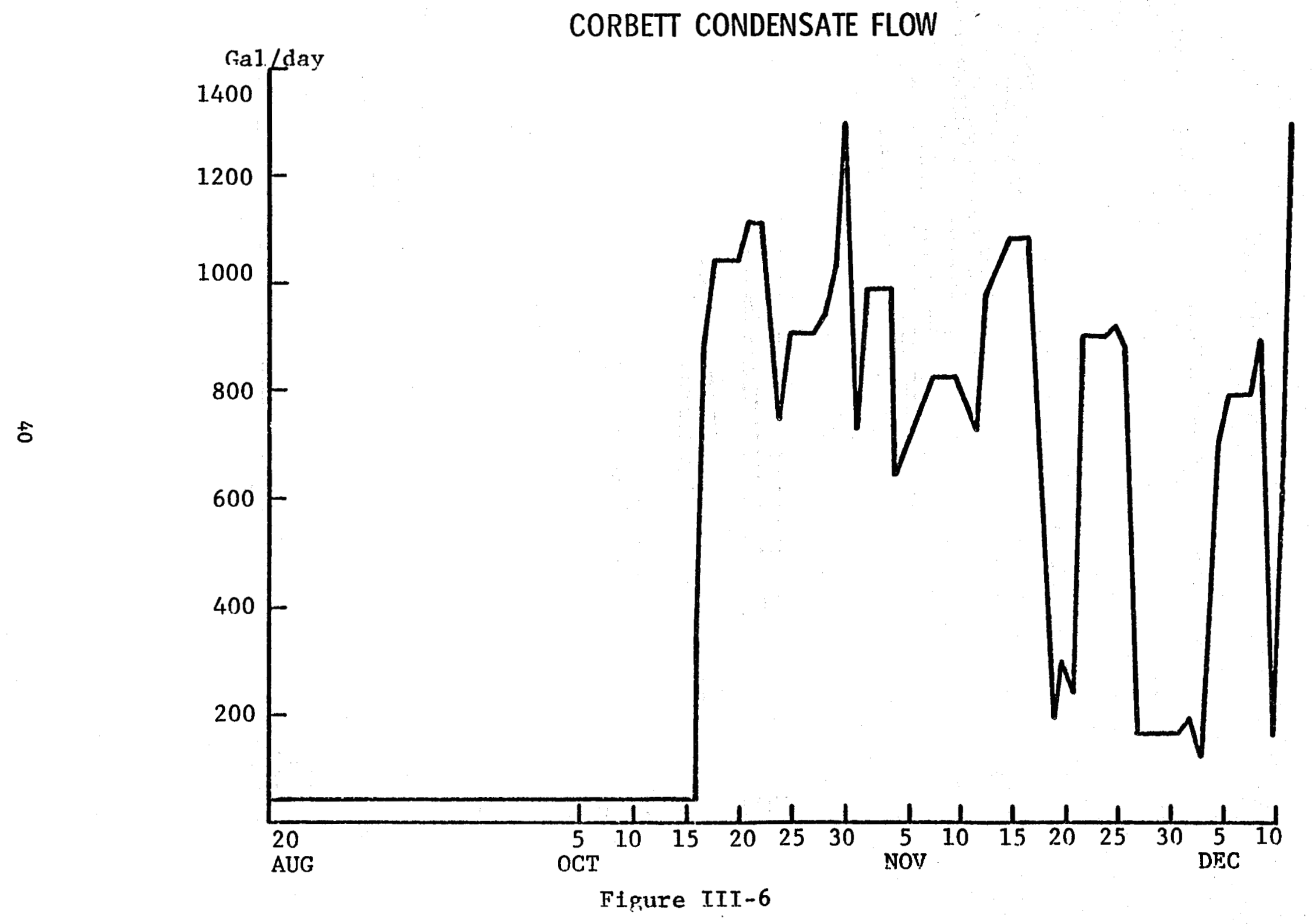




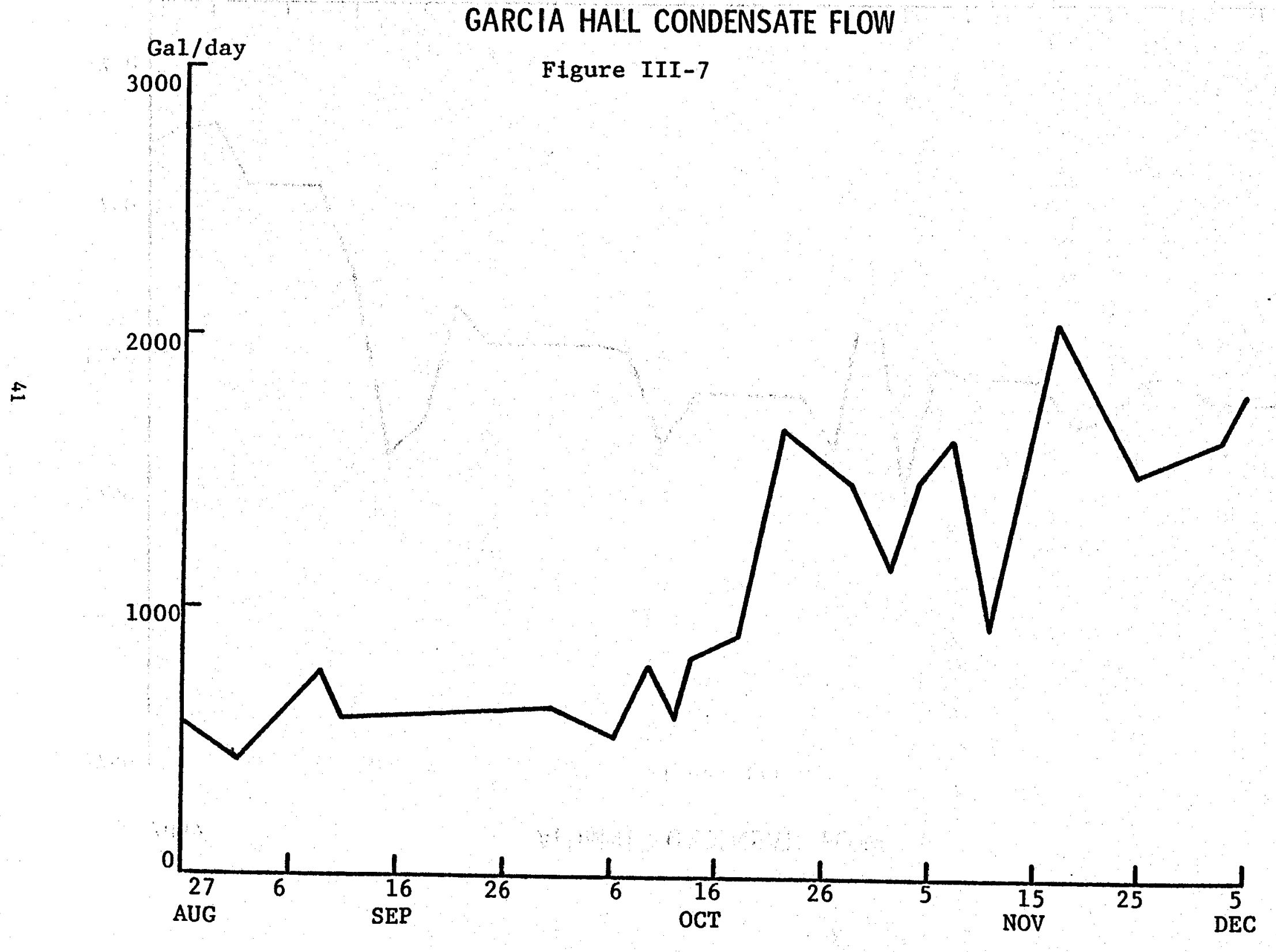




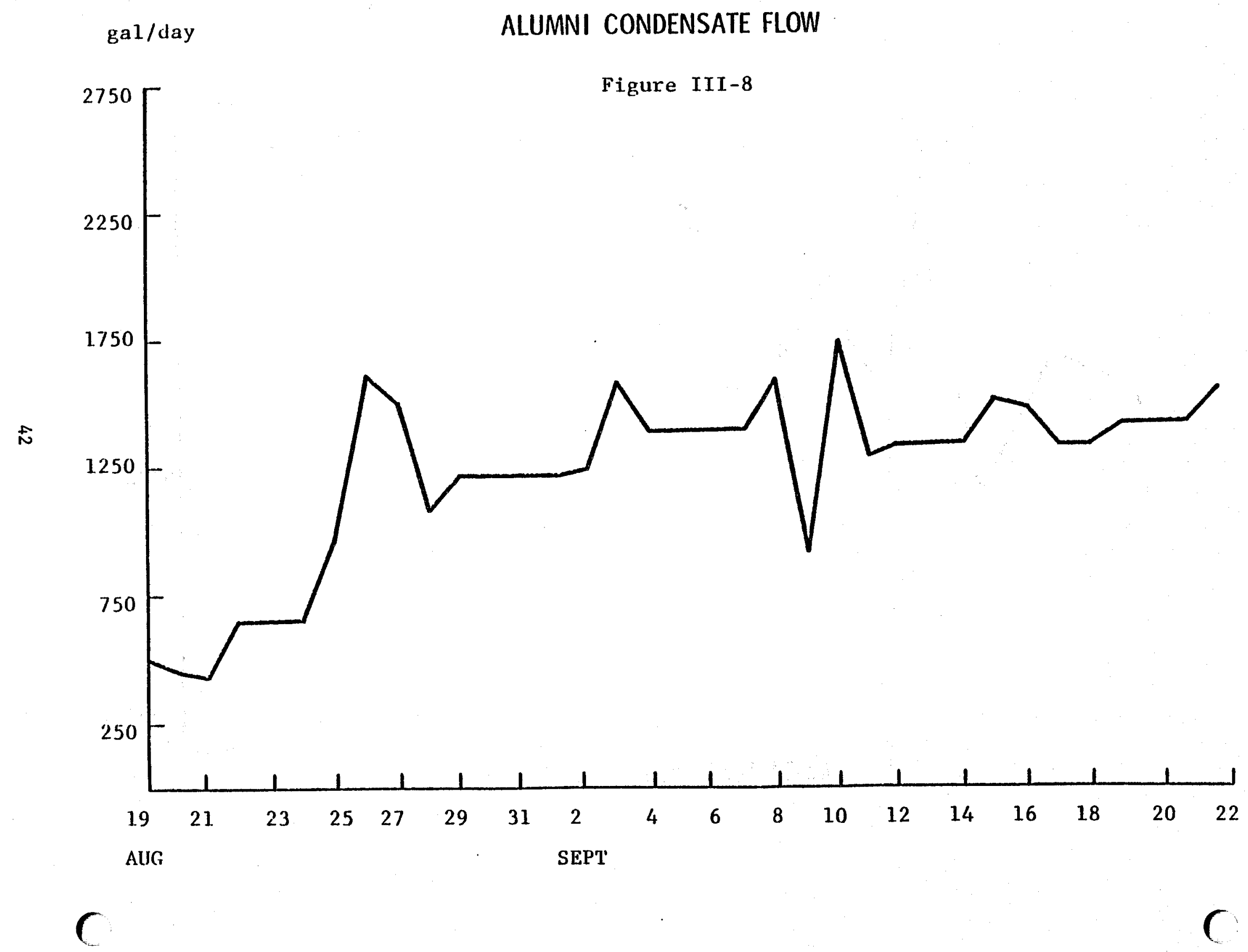




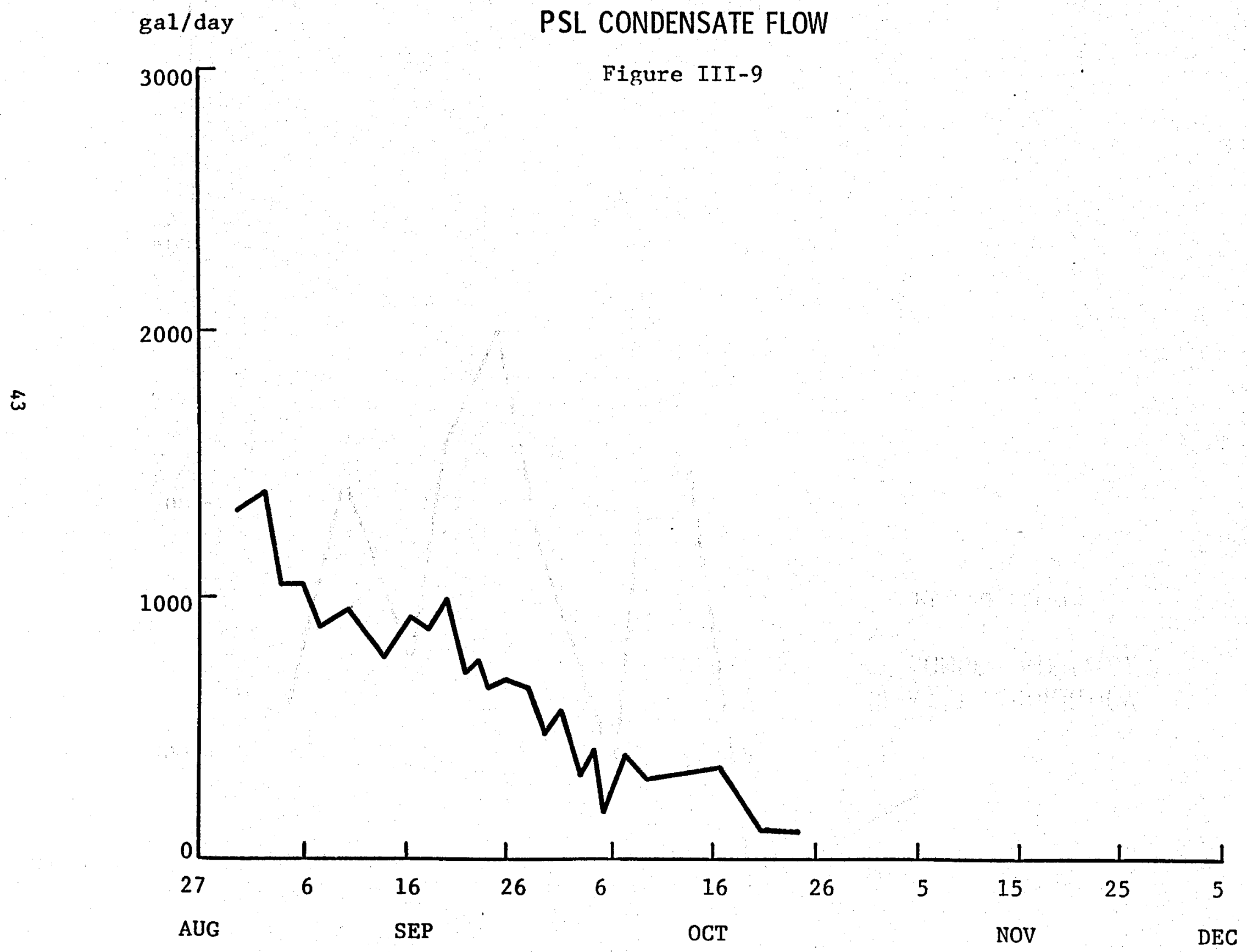




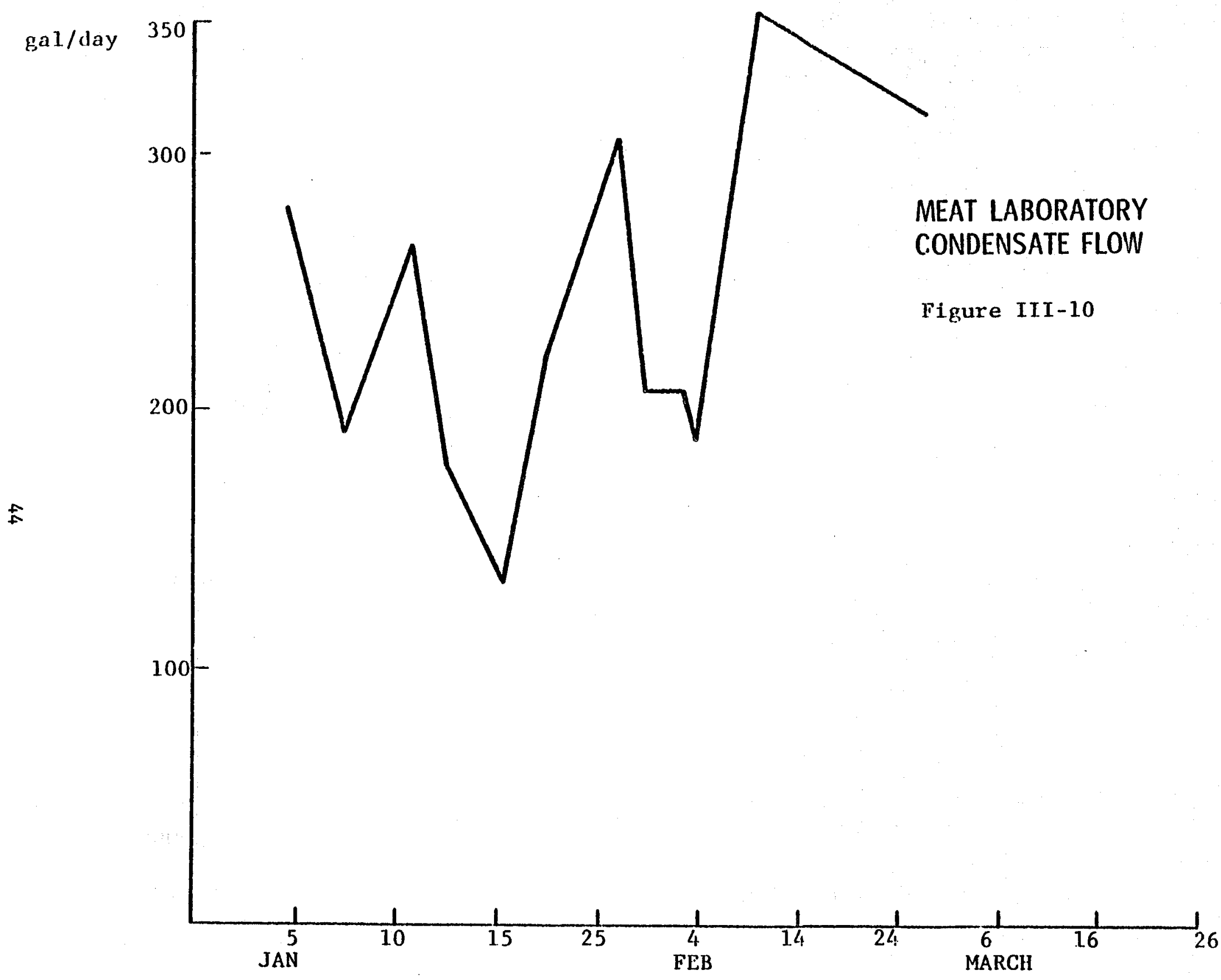




\section{Section IV}

\section{OUTDOOR SWIMMING POOL}

\section{General}

The NMSU Outdoor Swimming Pool is a 550,000 gallon pool which is used for instructional and recreational purposes. This pool is connected physically to the Natatorium Complex, which also houses the indoor pool. On the East side, the pool is connected with the Activity Center.

\section{Operations}

Because the pool is uncovered, it is open only during the warmer months of the year. Normally, the pool opens in late April and closes in mid-October. This period of time enables scheduling of instructional swimming classes the last six weeks of the Spring Semester, during the summer sessions, and the first six weeks of the Fall Semester. In a typical session, the pool and supporting staff will provide lessons for 18 scheduled classes, and 480 students per week. An additional 200 to 400 students and faculty members use the pool for recreation on a regular basis. This pool also is used heavily on a fee basis by the general public in the summer months, because Las Cruces has a relatively small number of large swimming pools.

\section{Heating Season}

In order to extend the swimming season to gain the instructional uses, the pool is heated in April, May, September, and October each year. 
The heating system is a steam heat exchanger, with the normal swimming pool recirculation system used to provide the circulation through the heat exchanger. As an economy measure, NMSU also purchased an insulated pool cover, which is manually stretched over the pool at night and during inclement weather to reduce heat losses. In a typical yearly usage pattern, the pool will use approximately the equivalent of 1200 MCF of natural gas. In terms of 1980 steam costs, this steam operating cost was $\$ 9,100$.

\section{Construction Factors}

The pool is surrounded on three sides by walls, which are 10-12 feet high. On the north side, a low wall provides partial blockage of winds, but a 4-feet high truck gate provides an easy entrance for cool northerly winds. Adequate space exists to install a separate heat exchanger required for conversion of the heating system to geothermal energy.

\section{Assessment of Heat Load}

To measure the heating load, a turbine flowmeter and recorder were installed. Water temperature measurements were available from an existing thermo-well installation. To check the accuracy of this temperature gauge, a separate temperature transducer and recorder also were installed. This test equipment was left in place from September thru pool-closing, just before Thanksgiving. To determine the efficiency of the steam heat exchanger, a condensate meter was installed to record actual steam consumption. 
The customary swimming pool season normally resulted in the pool being closed during the coldest months from 15 October through 15 April. Part of the design objective was to assess the economic feasibility of keeping the pool open year-around. It was believed that extrapolation of moderate weather data would lead to a potential danger of undersizing the heating system. This could be compensated by an engineering overdesign, but this solution would be inherently expensive and could lead to wasting geothermal energy.

Coordination with the NMSU Athletic Department and the Physical Plant Department resulted in an extension of the heating season until the end of November. This plan was placed into effect in late September. Thus, we had two months of heating season in which to gather data. A separate instrumentation and data collection scheme was devised.

\section{Special Instrumentation System}

The research team had an available empirical methodology for estimating the heating load for outdoor pools. The methodology was developed by Joseph Farber, President of Solar Research Systems, Costa Mesa, Calif., and is as follows:

$$
\begin{aligned}
\mathrm{qh}= & (0.2+0.3 \mathrm{~V})(\mathrm{tw}-\mathrm{ta})+23.75+184.6\left(0.2 \mathrm{~V}+0.06 \mathrm{~V}^{2}\right)-0.8 \mathrm{I} \\
\mathrm{qh} & =\text { heat load in } \mathrm{BTU} / \mathrm{ft}^{2}-\mathrm{hr} \\
\mathrm{V} & =\text { wind velocity in mph; } \\
\mathrm{tw} & =\text { desired temp of water }{ }^{\circ} ; \\
\mathrm{ta} & =\text { avg temp of air, }{ }^{\circ} \mathrm{F} \\
I & =\text { solar radiation on horizontal surface BTU/ft } \mathrm{ft}^{2} \mathrm{hr}
\end{aligned}
$$

To use the methodology, it is necessary to know or estimate wind velocity, ambient air temperature, relative humidity at the pool surface, water 
temperature, solar insolation, and pool design. This methodology has no provision for an insulated pool cover. Thus, to acquire data for this methodology, the research team installed a 24-hour recording temperature monitoring device, and two wind velocity measurement devices which sample and record wind speed and direction every six minutes. These automatic data collections were supplemented by acquiring relative humidity four times daily. In addition, we had our data collection set-up for poól temperature, recirculation rate, and steam consumption. Moreover, pool supervisory personnel developed a continuous record of swimming pool usage and the periods of time the pool was covered.

\section{Analysis of Data}

Based upon historical records available to the Physical Plant Department, and historical weather data developed by $\mathrm{Dr}$. Norm Malm of the NMSU Weather Station, a trial balance was made on an estimated heating load. From these calculations, it was determined that a best-fit correlation could be made only if the NMSU "normals" for wind velocity were artificially reduced to 25 percent of actual. A reduction of this magnitude is consistent with the sheltering effect of the pool, surrounded by walls on three sides, and the insulated pool cover.

After two months of data collection and analysis, an excellent correlation was made between the empirical formula and the actual heating load as determined from steam consumption. As was anticipated, the velocity and direction of the wind have the largest effect on heating load, with relative humidity playing a lesser role. Black body radiation and night-time losses were almost eliminated by use of the insulated pool cover. 
Based on analysis of data collected, a superior methodology was developed to estimate heating loads for the period December - mid-April when the steam system was disconnected. From these data, it was determined that applying a reducing factor to wind velocity would permit a correlation sufficiently close for engineering design. We could not depend on 20-year or 30-year "normals" for wind velocity, however, because these normals are not indicative of actual values at the pool deck. Accordingly, a decision was made to leave the wind velocity recorders in place until June 1981. We would then use the actual wind data to calculate a month-by-month heating load for an entire heating year. A summary of calculated and actual heating loads is contained in the following table.

Table IV-1

Outdoor Pool Heating Load

\begin{tabular}{|c|c|c|c|}
\hline \multicolumn{4}{|c|}{ ACTUAL MONTHLY } \\
\hline September & $\frac{2.94 \times 10^{8}}{2.94}$ & $\begin{array}{c}\text { negligible; abnormally } \\
\text { warm weather }\end{array}$ & $4.1 \times 10^{5}$ \\
\hline $\begin{array}{l}\text { October } \\
\text { November }\end{array}$ & $\begin{array}{l}3.09 \times 10^{8} \\
2.554 \times 10^{8}\end{array}$ & $\begin{array}{l}3.089 \times 10^{8} \\
2.591 \times 10^{8}\end{array}$ & $\begin{array}{l}4.1 \times 10^{5} \\
4.1 \times 10^{5}\end{array}$ \\
\hline December & $4.43 \times 10^{8}$ & not heated (pool closed) & $6 \times 10^{5}$ \\
\hline January & $4.84 \times 10^{8}$ & not heated (pool closed) & $6.5 \times 10^{5}$ \\
\hline bruary & $5.48 \times 10^{8}$ & not heated (pool clos & $8.1 \times 10^{5}$ \\
\hline $\operatorname{arch}$ & $4.88 \times 10^{8}$ & not heated (pool clo & $6.6 \times 10^{5}$ \\
\hline ril & $5.45 \times 10^{8}$ & not heated (pool clo & $7.6 \times 10^{5}$ \\
\hline
\end{tabular}

\section{Engineering Design}

From data and observations, it was determined that the heat load would necessitate a heat-exchanger large enough to accommodate a flow of up to $200 \mathrm{gpm}$ of geothermal water, and a like volume of recirculating pool water. Using the estimated geothermally heated water temperature of 
$125^{\circ} \mathrm{F}$, and a counterflow plate-type heat exchanger, we could attain a constant pool temperature of $80^{\circ} \mathrm{F}$. This design optimizes on a $20^{\circ} \mathrm{F}$ approach temperature across the heat exchanger. This design would still provide required heating if the geothermal water temperature dropped as low as $115^{\circ} \mathrm{F}$. Moreover, this heat exchanger would be amply sized to handle the heating load in the normal seasonal usage thru 15 October, but also would enable the system to provide service if operational and instructional needs created a demand for an extended season. To be compatible with the heavily chlorinated swimming pool water, the heat exchanger would be constructed of titanium-clad stainless steel. A price quotation was obtained from several prospective vendors -- see Section VIII.

Based on a probable heat load of 0.4 to 1.0 million BTU's per hour, a flow rate of $80 \mathrm{gpm}$ of $125^{\circ}$ water is required. The conceptual design selected for use analysis is a $110 \mathrm{gpm}$ plate-type exchanger, which provides a safety margin and a built-in basis for possible expansion. Required and available loads are depicted in the following table:

Table IV-2

Outdoor Pool Design Heating Load

\begin{tabular}{cc} 
FLOW RATE & MONTHLY LOAD AVAILABLE \\
\hline 80 & $5.76 \times 10^{8} \mathrm{BTU}$ \\
100 & $7.2 \times 10^{8} \mathrm{BTU}$ \\
110 & $7.9 \times 10^{8} \mathrm{BTU}$
\end{tabular}

LOAD REQUIRED

3 to $5 \times 10^{8}$ BTU Peak load Safety factor of $50 \%$ over design. 
Table IV-3

\section{Calculations of heating loads for outdoor pool}

OUTDOOR POOL HEAT LOAD

\section{September}

\section{Using September weather data}

$$
\begin{aligned}
& \mathrm{I}=85.34 \mathrm{BTU} / \mathrm{ft}^{2}-\mathrm{hr} \\
& \text { Avg Temp }=71.9^{\circ} \mathrm{F} \\
& \text { Avg Wind Speed }=6.2 \mathrm{mph} \\
& \mathrm{V}=0.25(6.2)=1.55 \mathrm{mph} \\
& q_{h}=(0.2+0.3 V)\left(t_{w}-t_{a}\right)+23.75+184.6\left(0.2 V+0.06 V^{2}\right)-0.8 I \\
& q_{h}=(0.2+0.3(1.55))(80-71.9)+23.75+184.6\left(0.2(1.55)+0.06(1.55)^{2}\right) \\
& -0.8(85.34) \\
& q_{h}=44.70 \mathrm{BTU} / \mathrm{ft}^{2}-\mathrm{hr} \\
& q=44.70(9148)=4.09 \times 10^{5} \mathrm{BTU} / \mathrm{hr} \\
& q_{\text {day }}=9.81 \times 10^{6} \mathrm{BTU} / \mathrm{day} \\
& q_{\text {month }}=2.94 \times 10^{8} \mathrm{BTU} / \text { month }
\end{aligned}
$$


Table IV-3 (continued)

OUTDOOR POOL HEAT LOAD

October

Using October Flow and Temp Data

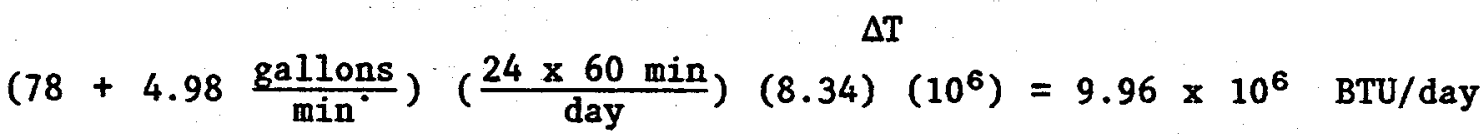

for October $3.089 \times 10^{8} \mathrm{BTU} / \mathrm{MONTH}$ 


\section{Table IV-3 (continued)}

OUTDOOR POOL HEAT LOAD

\section{October}

\section{Using October weather data}

$$
\begin{aligned}
& I=69.64 \mathrm{BTU} / \mathrm{ft}^{2}-\mathrm{hr} \\
& \text { Avg Temp }=57.8^{\circ} \\
& \text { Avg Wind Speed }=2.985 \mathrm{mph}
\end{aligned}
$$

$$
\begin{aligned}
& V=0.424(2.985)-1.266 \mathrm{mph} \\
& q_{h}=(0.2+0.3 V)\left(t_{w}-t_{a}\right)+23.75+184.6\left(0.2 V+0.06 V^{2}\right)-0.8 I \\
& q_{h}=[0.2+(0.3)(1.266)](80-57.8)+23.75+ \\
& 184.6\left[0.2(1.266)+0.06(1.266)^{2}\right]-0.8(69.64) \\
& q_{h}=12.872+23.75+64.493-55.712 \\
& q_{h}=45.403 \mathrm{BTU} / \mathrm{ft}^{2}-\mathrm{hr} \\
& q=\left(45.403 \mathrm{BTU} / \mathrm{ft}^{2}-\mathrm{hr}\right)\left(9148 \mathrm{ft}^{2}\right)=4.154 \times 10^{5} \mathrm{BTU} / \mathrm{hr} \\
& q_{\text {day }}=\left(4.154 \times 10^{5} \mathrm{BTU} / \mathrm{hr}\right)(24 \mathrm{hr} / \text { day })=9.968 \times 10^{6} \mathrm{BTU} / \mathrm{day} \\
& q_{\text {month }}=3.09 \times 10^{8} \mathrm{BTU} / \text { month }
\end{aligned}
$$


Table IV-3 (continued)

\section{CALCULATION OF WIND CORRECTION FACTOR}

\section{$\underline{\text { from October data }}$}

$2.985 \mathrm{mph}=$ avg wind speed (from Station F Wind Summary) Sept. 30 thru Nov. 3

$$
\begin{aligned}
& 57.8^{\circ} \mathrm{F}=\text { avg temp (from Climatological Summary - NOAANWS) } \\
& q_{h}=(0.2+0.3 V)\left(t_{w}-t_{a}\right)+23.75+184.6\left(0.2 V+0.06 V^{2}\right)-0.8 I \\
& q_{h}=45.391 \frac{B T U}{\mathrm{ft}^{2}-h r} \text { (from flow data) } \\
& 45.391=(0.2+0.3 V)(80-57.8)+23.75+184.6\left(0.2 V+0.06 V^{2}\right)-0.8(69.64) \\
& V^{2}+3.9346 V=6.583 \text { Solve for } V \\
& \mathrm{~V}=1.267 \mathrm{mph} \\
& \mathrm{V}_{\text {actual }}=2.985 \mathrm{mph} \\
& \text { Correction factor (for October) }=\frac{1.267}{2.985}=\underline{\underline{0.424}}
\end{aligned}
$$


Table IV-3 (continued)

\section{OUTDOOR POOL HEAT LOAD}

November

Using November Flow and Temp Data

$(78+4.98) \frac{24 \times 60 \mathrm{~min}}{\text { day }}(8.34)(10)=9.966 \times 10^{6} \mathrm{BTU} / \mathrm{day}$

for November $2.591 \times 10^{8} \mathrm{BTU} /$ month 


\section{Table IV-3 (continued)}

OUTDOOR POOL HEAT LOAD

November

\section{Using November Weather Data}

$$
\begin{aligned}
& I=53.56 \mathrm{BTU} / \mathrm{ft}^{2}-\mathrm{hr} \\
& \text { Avg. Temp }=48.3^{\circ} \\
& \text { Avg Wind Speed }=2.75 \mathrm{mph}
\end{aligned}
$$

$$
\begin{aligned}
& \text { Wind blockage (pool cover) } 64 \% \\
& V=0.36(2.75)=1.0 \mathrm{mph} \\
& q_{h}=(0.2+0.3 V)\left(t_{w}-t_{a}\right)+23.75+184.6\left(0.2 V+0.06 V^{2}\right)-0.8 I \\
& q_{h}=(0.2+0.3(1.0))(80-48.3)+23.75+184.6\left(0.2(1.0)+0.06(1.0)^{2}\right) \\
& -0.8(53.56) \\
& q_{h}=15.85+23.75+47.996-42.848 \\
& q_{h}=44.748 \mathrm{BTU} / \mathrm{ft}^{2}-\mathrm{hr} \\
& \mathrm{q}=44.748\left(9148 \mathrm{ft}^{2}\right)=4.094 \times 10^{5} \mathrm{BTU} / \mathrm{hr} \\
& q_{\text {day }}=0.982 \times 10^{7} \mathrm{BTU} / \mathrm{day}
\end{aligned}
$$$$
q_{\text {month }}=2.554 \times 10^{8} \mathrm{BTU} / \text { month }
$$ 
OUTDOOR POOL HEAT LOAD

\section{December}

Using weather data

$$
\begin{aligned}
& I=45.62 \mathrm{BTU} / \mathrm{ft}^{2}-\mathrm{hr} \\
& \text { Avg Temp }=46.3^{\circ} \mathrm{F} \\
& \text { Avg Wind Speed }=3.3 \mathrm{mph}
\end{aligned}
$$

Wind blockage assumed $64 \%$

$V=0.36(3.3)=1.19 \mathrm{mph}$

$$
\begin{aligned}
q_{h} & =(0.2+0.3(1.19))(80-46.3)+23.75+184.6(0.2(1.19) \\
& \left.+0.06(1.19)^{2}\right)-0.8(46.3)
\end{aligned}
$$

$q_{h}=65.08 \mathrm{BTU} / \mathrm{ft}^{2}-\mathrm{hr}$

$\mathrm{q}=65.08\left(9148 \mathrm{ft}^{2}\right)=5.95 \times 10^{5} \mathrm{BTU} / \mathrm{hr}$

$q_{\text {day }}=1.43 \times 10^{7} \mathrm{BTU} / \mathrm{day}$

$q_{\text {month }}=4.43 \times 10^{8} \mathrm{BTU} /$ month for December 


\section{Table IV-3 (continued)}

OUTDOOR POOL HEAT LOAD

\section{January}

Using weather data

$$
\begin{aligned}
& \mathrm{I}=50.43 \mathrm{BTU} / \mathrm{ft}^{2}-\mathrm{hr} \\
& \text { Avg Temp }=43.9^{\circ} \mathrm{F} \\
& \text { Avg Wind Speed }=3.6 \mathrm{mph}
\end{aligned}
$$

Wind blockage assumed $64 \%$

$\mathrm{V}=0.36(3.6)=1.29 \mathrm{mph}$

$$
\begin{aligned}
& q_{h}=(0.2+0.3(1.19))(80-46.3)+23.75+184.6(0.2(1.29) \\
& \left.\quad+0.06(1.29)^{2}\right)-0.8(46.3) \\
& q_{h}=70.66 \mathrm{BTU} / \mathrm{ft}^{2}-\mathrm{hr} \\
& q=70.66(9148 \mathrm{ft} 2)=4.46 \times 10^{5} \text { BTU/hr } \\
& q_{\text {day }}=1.55 \times 10^{7} \mathrm{BTU} / \text { day } \\
& \mathrm{q}_{\text {month }}=4.81 \times 10^{8} \text { BTU/month for January }
\end{aligned}
$$




$$
\text { Table IV-4 }
$$

Swimming Pool Weather Data

SWIMMING POOL DATA

WEATHER

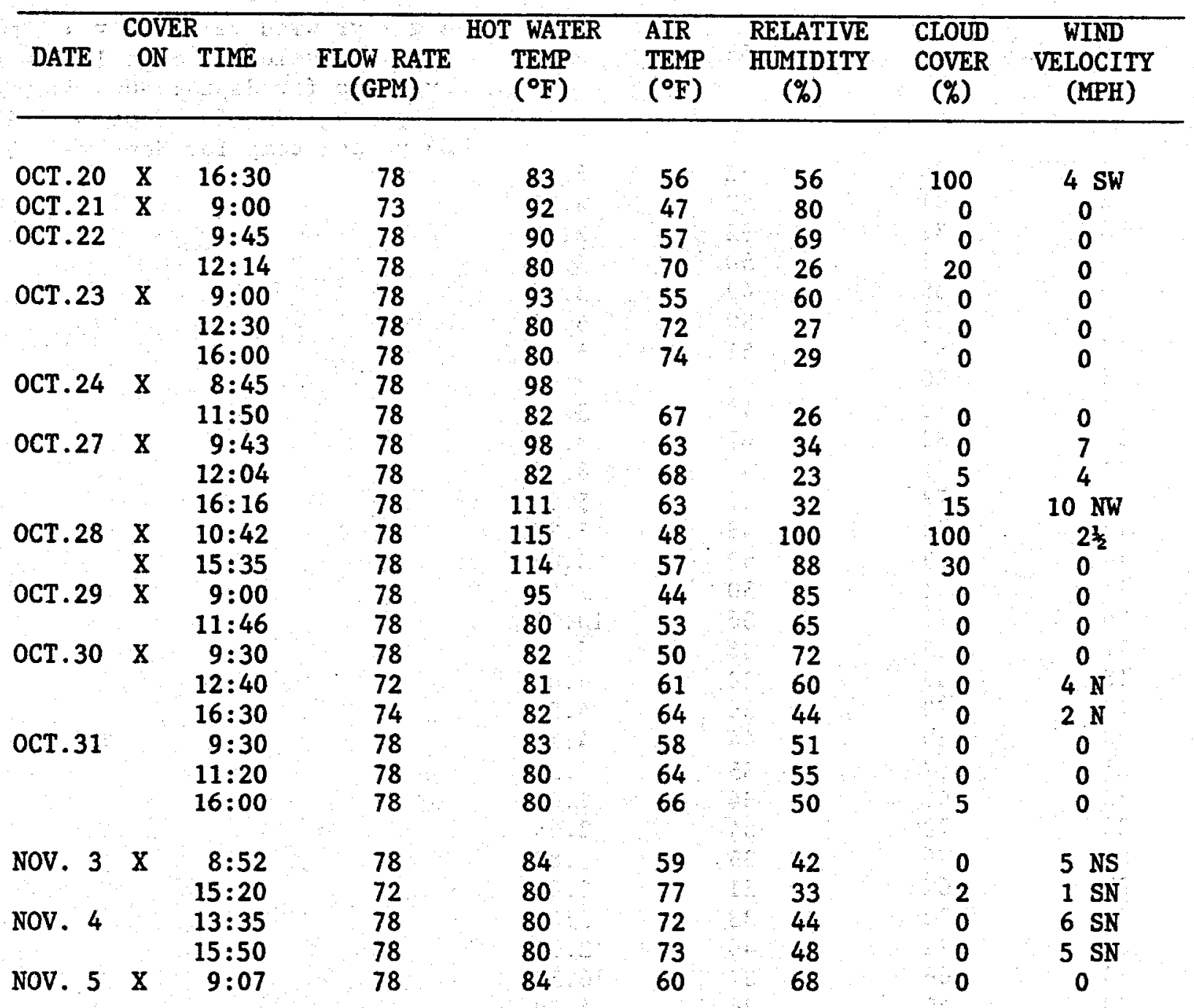


Table IV-5

Wind Summary

\begin{tabular}{|c|c|c|c|}
\hline DATE & $\begin{array}{l}\text { HIGH TEMP } \\
{ }^{\circ} \mathrm{F}\end{array}$ & $\begin{array}{l}\text { LOW TEMP } \\
{ }^{\circ} \mathrm{F}\end{array}$ & $\begin{array}{r}\text { WIND } \\
\text { VELOCI } \\
\text { mph }\end{array}$ \\
\hline 30 SEPT & 86 & 55 & 4.28 \\
\hline $1 \mathrm{OCT}$ & 88 & 52 & 6 \\
\hline 2 & 91 & 52 & $\begin{array}{l}0.41 \\
4.25\end{array}$ \\
\hline 3 & 82 & 52 & 12.90 \\
\hline 4 & 81 & 50 & 3.58 \\
\hline 5 & 86 & 49 & 3.96 \\
\hline 6 & 87 & 50 & 4.55 \\
\hline 7 & 83 & 51 & 6.13 \\
\hline 8 & 80 & 49 & 3.66 \\
\hline 9 & 82 & 47 & 3.37 \\
\hline 10 & 82 & 47 & 3.58 \\
\hline 11 & 81 & 43 & 8.96 \\
\hline 12 & 78 & 47 & 5.06 \\
\hline 13 & 78 & 48 & 3.87 \\
\hline 14 & 79 & 50 & 3.66 \\
\hline 15 & 81 & 50 & 7.54 \\
\hline 16 & 76 & 36 & 10.23 \\
\hline 17 & 65 & 36 & 6.47 \\
\hline 18 & 69 & 38 & 4.08 \\
\hline 19 & 70 & 36 & 4.81 \\
\hline 20 & 60 & 44 & 4.22 \\
\hline 21 & 57 & 35 & 4.21 \\
\hline 22 & 63 & 34 & 2.66 \\
\hline 23 & 73 & 34 & 2.65 \\
\hline 24 & 76 & 35 & 3.83 \\
\hline 25 & 67 & 31 & 2.89 \\
\hline 26 & 72 & 33 & 3.64 \\
\hline 27 & 72 & 46 & 12.74 \\
\hline 28 & 66 & 37 & 16.52 \\
\hline 29 & 45 & 26 & 4.30 \\
\hline 30 & 55 & 26 & 2.70 \\
\hline 31 & 65 & 29 & 3.00 \\
\hline
\end{tabular}

Avg 7 yr wind velocity $=4.3 \mathrm{mph}$

Avg wind velocity Sept $1980=6.2$

Avg temp for Sept $1980=71.9^{\circ}$

7 yr avg temp for Sept $=71.7^{\circ}$

$84 \mathrm{yr}$ avg temp for Sept $=71.5^{\circ}$

4.25

12.90

3.58

4.55

6.13

3.66

3.58

8.96

5.06

3.87

3.66

7.54

0.23

6.47

4.08

4.81

4.22

4.21

2.65

3.83

2.89

3.64

12.74

4.30

2.70

3.00

Avg 7 yr wind velocity $=4.2 \mathrm{mph}$

Avg wind velocity Oct $1980=7.3$

Avg temp for Oct $1980=57.8^{\circ}$

7 yr avg temp for oct $=60.8^{\circ}$

84 yr avg temp for Oct $=60.6^{\circ}$

$\begin{array}{llll}1 \text { NOV } & 69 & 37 & 3.05 \\ 2 & 73 & 34 & 2.99 \\ 3 & 75 & 35 & 3.19 \\ 4 & 80 & 38 & 4.05 \\ 5 & 74 & 37 & 3.32 \\ 6 & 77 & 38 & 2.61 \\ 7 & 79 & 37 & 3.07 \\ 8 & 82 & 33 & 2.78 \\ & & & 60\end{array}$


Table IV-5 (cont.)

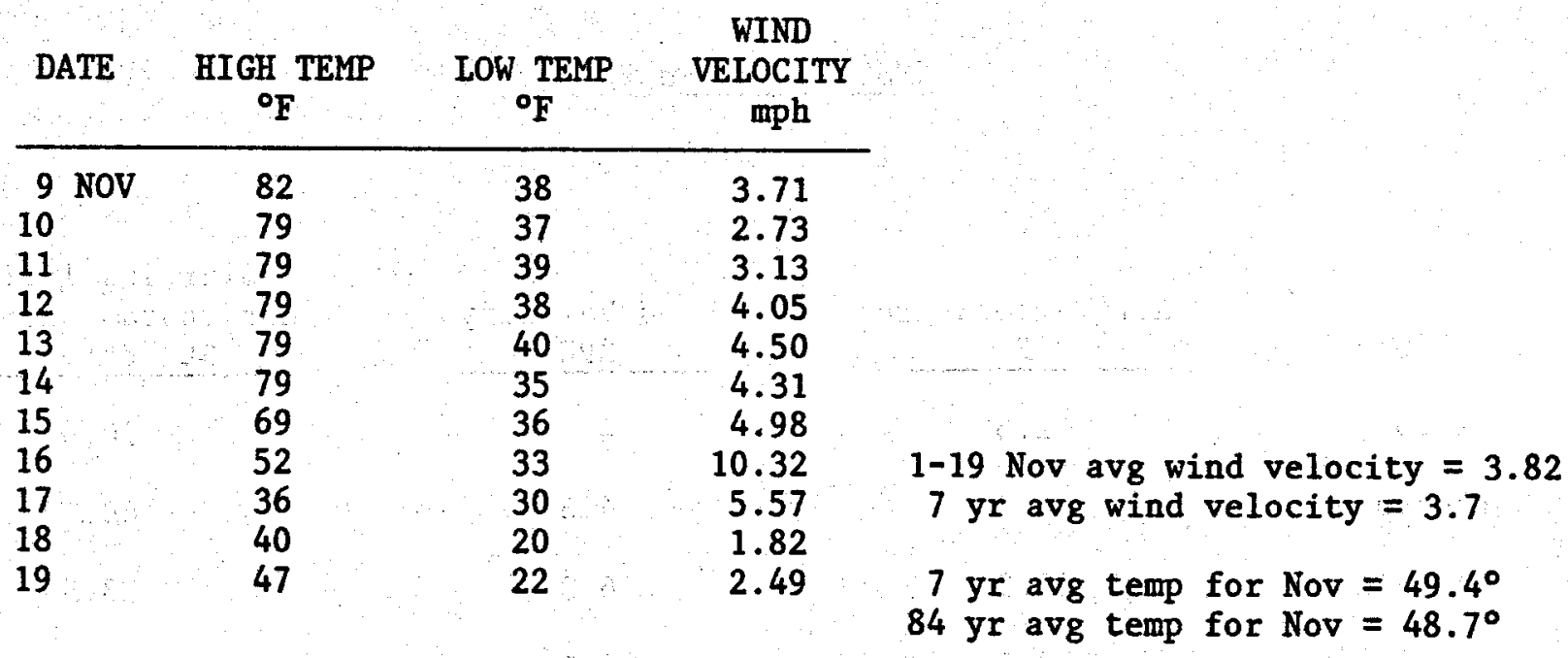


Table IV-6

NMSU Campus Weather Data

$$
\text { (1970 - } 1977 \text { Average) }
$$

\begin{tabular}{|c|c|c|c|}
\hline Month & $\begin{array}{c}\text { Air Temperature } \\
{ }^{\circ} \mathrm{F}\end{array}$ & $\begin{array}{c}\text { Wind Velocity } \\
\text { MPH } \\
\end{array}$ & $\begin{array}{c}\text { Solar Insolation } \\
\text { Horizontal surface } \\
\text { Btu/Ft } \mathrm{Ft}^{2}-\mathrm{Hr} \\
\end{array}$ \\
\hline January & 42.6 & 4.6 & 50.43 \\
\hline February & 46.7 & 4.6 & 60.72 \\
\hline March & 53.2 & 6.3 & 78.59 \\
\hline April & 58.5 & 6.5 & 96.54 \\
\hline May & 67.2 & 5.7 & 95.32 \\
\hline June & 76.8 & 5.1 & 111.68 \\
\hline July & 79.7 & 4.9 & 103.24 \\
\hline August & 77.5 & 4.2 & 96.82 \\
\hline September & 71.7 & 4.3 & 85.34 \\
\hline October & 60.8 & 4.2 & 69.64 \\
\hline November & 49.4 & 3.7 & 53.56 \\
\hline December & 43.0 & 4.3 & 45.62 \\
\hline
\end{tabular}




\section{PIPELINE DESIGN}

\section{General}

A number of different routes for piping the geothermal hot water to a heat exchanger, reinjection well and hot water storage tank complex were considered. The primary factors influencing the various piping schemes are cost, damage to the environment, pipe length, and maintenance of the maximum feasible hydraulic head.

\section{Design Overview}

The basic design to utilize the energy of the geothermal hot water is to pipe the geothermal water from the well to a heat exchanger. The heat exchanger will heat water drawn from the existing campus water system. This system runs from the four-million gallon water tank, under the frontage road east of I-25 and through a culvert under I-25 onto the various buildings on campus.

A flow of 200-250 gallons per minute of geothermal water at a temperature of about $140^{\circ} \mathrm{F}$ will feed the heat exchanger in a counter-flow method, The geothermal exhaust water from the heat exchanger will have a temperature of about $70^{\circ} \mathrm{F}$ and will be reinjected into the geothermal aquifer. Fresh water from the four million gallon tank campus water line will enter the heat exchanger at the rate of 200-250 gallons per minute at a temperature of about $60^{\circ} \mathrm{F}$ and leave at a temperature of about $130^{\circ} \mathrm{F}$. This hot potable water will then be piped directly to the campus buildings that require the supply. The buildings 
to be provided with hot water from the geothermal project will be the Alumni Avenue, Regent's Row, Garcia, Womens' Residence Center, and Rhodes-Garrett-Hamiel dormitories, and the Pan Am Center, Activity Center, Natatorium complex, Memorial Football Stadium, and the Student Health Center, and the Outdoor Instructional Pool.

The location of the heat exchanger, reinjection well and hot water storage tank complex will determine the length of pipe from the geothermal well to the complex. Two locations were analyzed for the complex.

The preferred location is in the vicinity of the four million gallon water tank. To blend with surroundings, the complex can be buried in that area, or located to the north-west side of the existing four-million gallon water tank. This location will screen the complex from the University Center. This location has the advantage of preserving the maximum hydraulic head and thereby saving in the cost of distributing the hot fresh water to the campus. It is also the shortest distance from the geothermal well to a heat exchanger, reinjection well and hot water storage tank complex.

Two different pipeline routes were selected for closer analysis to bring the geothermal hot water to the heat exchanger. These two were selected from seven separate routes evaluated on the basis of length of pipeline and potential damage to the environment. 
Route 2 (see map Figure $V-1$ ) was selected because it is a more direct route to the heat exchanger complex, and passes close to the President's new residence. This has the advantage of making additional geothermal hot water available to the new residence at a minimum cost in piping.

Description: Route 2 would follow Geothermal Drive from the well to the intersection with the existing powerline service road. At this point the pipeline would follow the contours at the side of an arroyo in a northwesterly direction until intersecting an existing road that runs east-west on the crest of the hills. The cross-country distance from road to road is about 1,400 feet, and the pipeline can be placed in a manner such that the construction would not be apparent from the University Center. When reaching the crestline road, the pipeline would follow the road to the parking lot of the University Center and turn to intersect with the trench carrying the existing waterline from the four million gallon tank to the Rodeo Arena. The geothermal hot water pipeline would follow this existing waterline to the heat exchanger complex.

Route 4 (see map, Figure V-1) was selected because of minimum environmental impact, while minimizing distance and cost. This route makes maximum use of terrain slopes, and provides optimal locations for a gas separator.

Description: From PW-1 west on Geothermal Drive to vicinity of plugged well; thence NW bypassing the University Center; then west along lowest portion of slope to $H / E$ complex vicinity of 4 million gallon water tank. 
a. Geothermal usage loop for golf course would head NW into golf course, across \#14 fairway, entering ravine east of No. 2 tee. Branch off to interconnect with golf course pump house and disposal system.

b. Heated domestic water would be in same trench as geothermal water; at the ravine the domestic hot water pipeline would be oriented westnorth-west, cutting across $\# 16$ and $\# 17$ fairway, and run west along road between $\# 17$ green and 非18 tee, and then enter the utility tunnel under I-25.

\section{Selection of Route}

After reviewing the distance, cost, construction impact on ecology, and esthetic consideration, Route 4 was selected as the primary route. This route was then surveyed for exact location and construction elevation profiles. Cost estimates were then made based solely on this route. Final route selection as coordinated with the Physical Plant Department, is likely to be a modification of Route 1, connecting to Route 4, and connecting with Route 2 at the heat exchanger. If approval is granted by the Highway Department, the route would pass under Interstate 25 through the south arroyo underpass, rather than the north utility underpass as shown on Figure $\mathrm{V}-1$. 
C

C

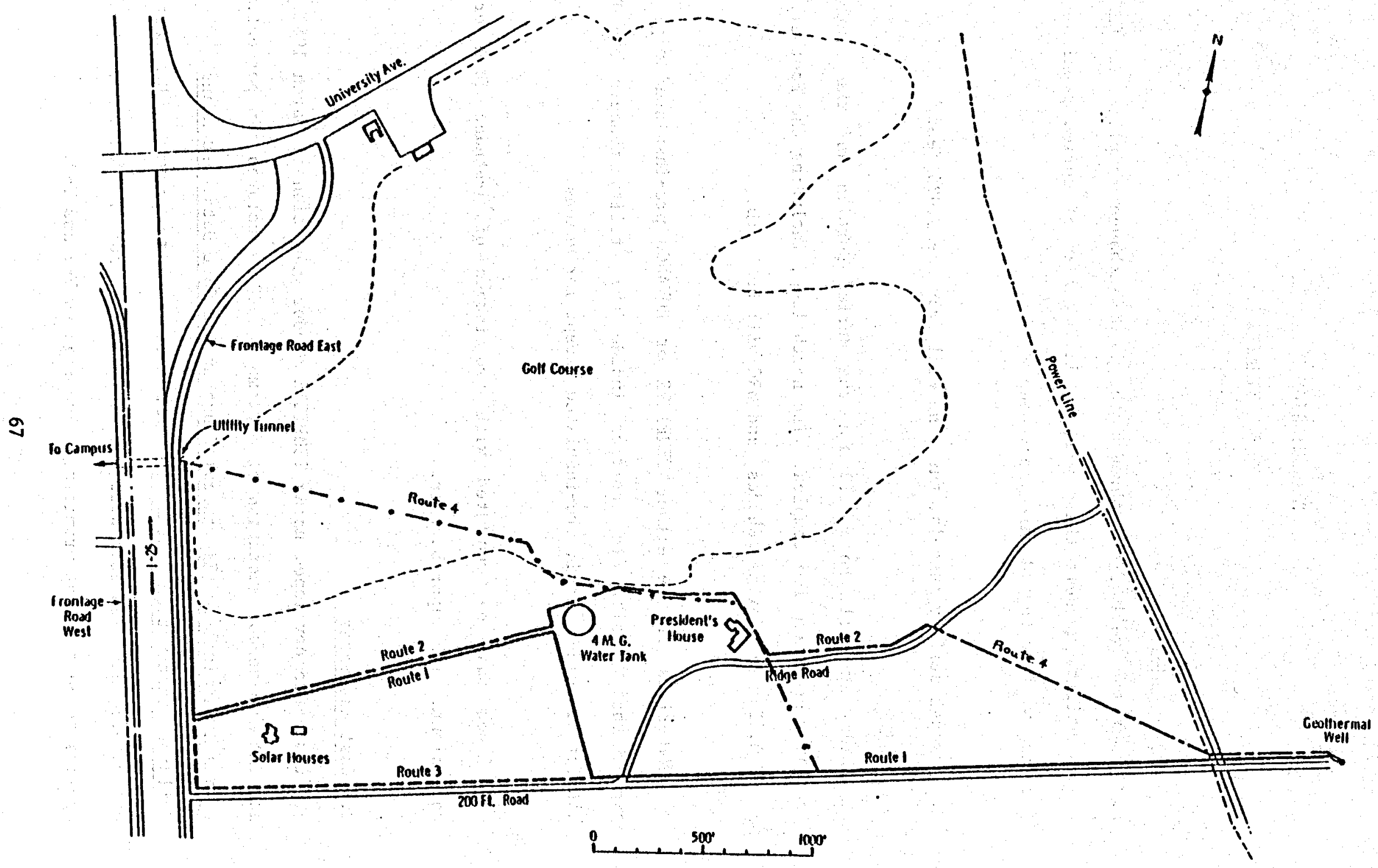

CAMPUS GEOTHERMAL PROJECT EAST OF 1-25 


\section{TRANSMISSION PIPELINE}

\section{COST ESTIMATES}

\section{Assumptions}

a. From the well field through the heat exchange complex, to the campus utility tunnels there will be 11,744 feet of buried pipeline. The line will be buried three feet deep.

b. Through utility tunnels, the line will traverse 5,025 feet.

c. Line size will be 6" ID for the buried portion and the south loop to the Natatorium complex. The north loop, including the Football Stadium, Pan Am, Garcia, Rhodes, and WRC will be 4" ID.

d. Materials can be either TEMPTITE or ROVANCO pre-insulated pipe, except that possibly the portion inside the utility tunnels could consist of welded steel, pre-insulated except for unions.

e. Lines must be insulated with two inches of urethane foam or equivalent, with vapor barrier.

\section{Cost Estimates}

a. Cost were developed using TEMPTITE vendor quotation of March 1981, and ROVANCO vendor quotation of September 1980, escalated ten percent. (Means Mechanical and Electrical Construction Cost Data, and Means Building Construction Cost Data, 1981 were used to provide 1982 cost estimate.) Detailed estimates are provided only for the Route $\$$, which appears to be the most promising. See Figures $\mathrm{V}-2$ and $\mathrm{V}-3$. 
b. Consideration was given only to the use of TEMPTITE or ROVANCO for the buried portion, because our earlier work ruled out as too costly the use of other alternatives. For the utility tunnel portion, cost estimates also were developed for a ROVANCO pre-insulted steel pipe which can be welded, or a welded steel pipeline which would require separately installed insulation. 


\section{CAMPUS GEOTHERMAL PIPELINE SYSTEM}

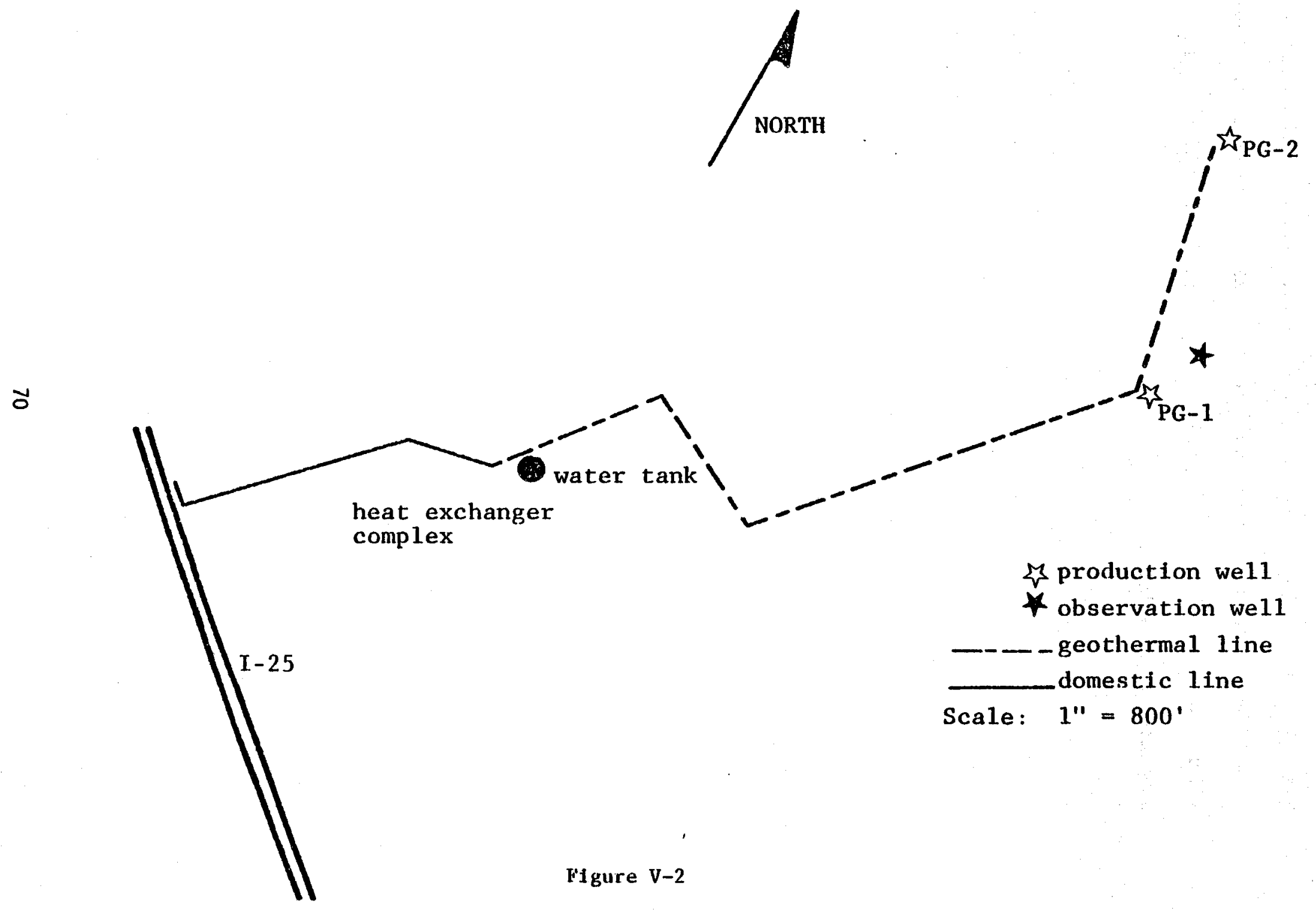




\section{DOMESTIC WATER LINES}

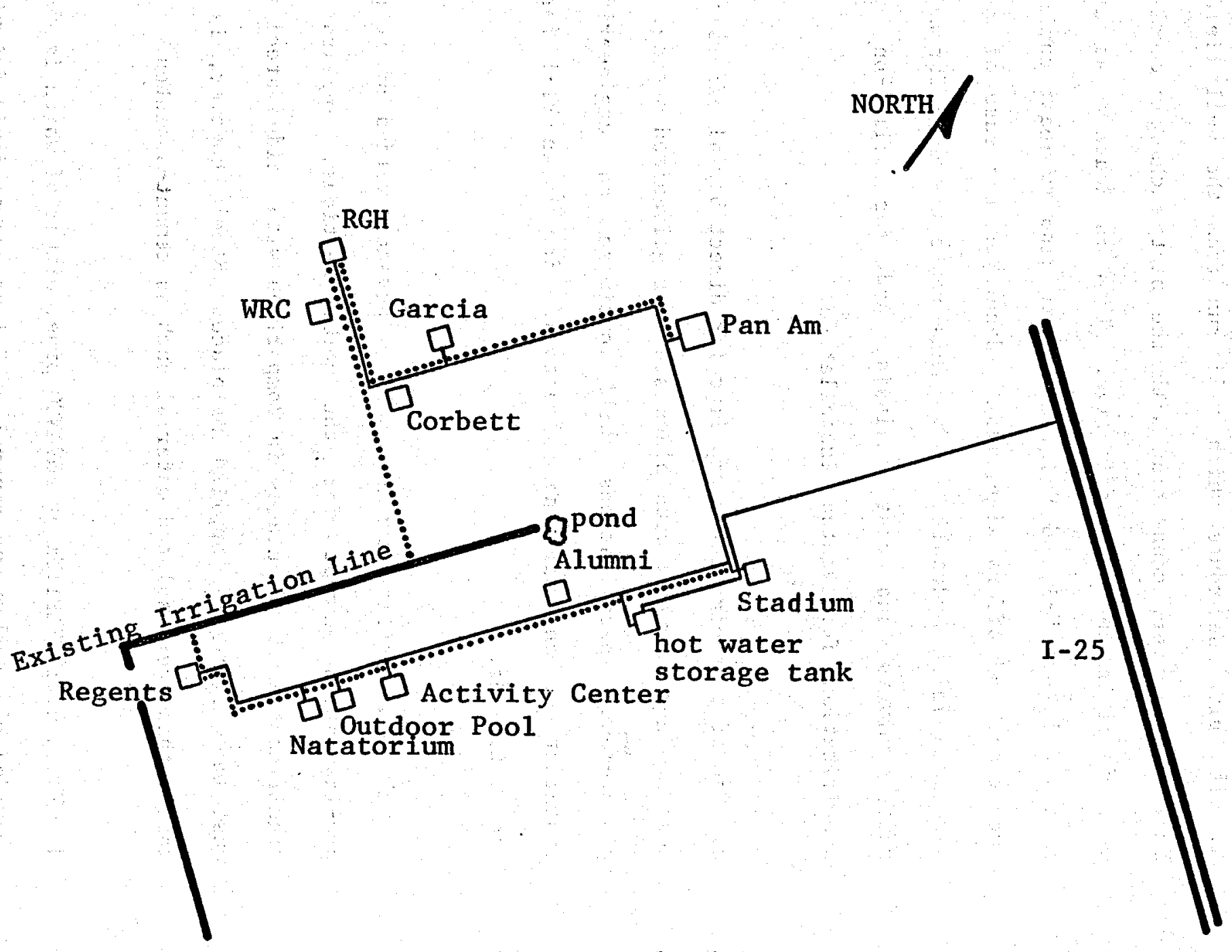

.......... Bleed lines

Scale $1^{\prime \prime}=800^{\prime}$

F1gure V-3 


\section{DESIGN CONCLUSIONS}

a. The pipeline route which will run from the well field past the University Center, connecting with the heat exchanger complex, is the most feasible and cost effective. This is Route 4 as depicted on attached Figure $V-1$ and $V-2$. This route also is least environmentally impacting, and offers significant advantages for ease of construction and maintaining hydraulic head. This route was used for all detailed route surveys and cost analysis, and for follow-on contractual specifications for eventual installation.

b. Use of a pre-insulated pipeline for direct burial offers significant cost savings compared with black steel or galvanized piping. The final procurement specifications will optimize on engineering, cost, installation, and maintenance factors. See Table VI-1 for detailed cost estimates.

c. For the utility tunnel, use of Rovanco welded steel pipe, with pre-insulation except for the weld sections, appears to offer significant cost advantages in comparison with welded steel pipe which must have insulation applied in place. Steel, however, is much more costly than pre-insulated material such as cement-asbestos.

d. The use of TEMPTITE or ROVANCO pipe, either of which is epoxy lined, provides clean flow and minimal head loss due to fluid friction. Based on roughness factors as provided by the vendors, and assuming ROVANCO steel or regular steel pipe for the tunnel section, head loss data have been estimated. These head loss data can be seen in Table $\mathrm{V}-2$. A review of this head loss data indicates that head gain due to decreasing 
elevation more than offsets the head loss due to fluid friction, except for a portion of the line between the gas separator and the University Center, which is a high point in the pipeline route. In-line pressure assist boost pumps will be required for the domestic water from the storage tank, for the pressurized hot water system, for the outlet from the gas separator, and for the disposal system.

\section{Table $V-1$}

\section{Detailed Cost Estimates}

(1) Well field to heat exchanger, 6-inch pipeline, 4,216 feet and 1130 feet of 4-inch pipe.

a. 6-inch pipeline, 4216 feet

\begin{tabular}{lrr} 
COST/FOOT & TEMPTITE & ROVANCO \\
\hline Material & 10.68 & 13.08 \\
Installation & 5.00 & 5.00 \\
Burial & 3.05 & 3.05 \\
Total/foot & 18.73 & 21.13 \\
Sub Total & $\$ 78,965.68$ & $\$ 89,084.08$
\end{tabular}

b. 4-inch pipeline, 1130 feet

\begin{tabular}{lrr} 
COST/FOOT & TEMPTITE & ROVANCO \\
\hline Material & 9.58 & 10.35 \\
Installation & 5.00 & 5.00 \\
Burial & 3.05 & 3.05 \\
Total/foot & 17.63 & 18.40 \\
Sub Total & $\$ 19,921.90$ & $\$ 20,792.00$
\end{tabular}

(2) Heat Exchanger to hot water storage tank, 4334 feet of 6 -inch pipe.

\begin{tabular}{lrr} 
COST/FOOT & TEMPTITE & $\frac{\text { ROVANCO }}{13.08}$ \\
\hline Material & 10.68 & 5.00 \\
Installation & 5.00 & 3.05 \\
Burial & 3.05 & 21.13 \\
Total/foot & 18.73 & \\
Sub Total & $\$ 81,175.82$ & $\$ 91,577.42$
\end{tabular}


Table V-1 (continued)

(3) Hot water storage tank to tunnel system, 2064 feet of 4-inch pipe.

\begin{tabular}{lrr} 
COST/FOOT & TEMPTITE & ROVANCO \\
\hline Material & 9.58 & 10.35 \\
Installation & 5.00 & 5.00 \\
Burial & 3.05 & 3.05 \\
Total/foot & 17.63 & 18.40 \\
Subtotal Cost & $\$ 36,388.32$ & $\$ 37,977.60$
\end{tabular}

(4) Total Cost, utility tunnel portion, assuming TEMPTITE or ROVANCO installation cost for thrust blocks and pipe hangers are equivalent to the burial cost.

$\begin{array}{lrr} & \text { TEMPTITE } & \text { ROVANCO } \\ \text { 6-inch }(2175 \text { feet }) & \$ 40,737.75 & \$ 45,957.75 \\ \text { 4-inch }(2850 \text { feet }) & \$ 50,245.50 & 52,440.00 \\ \text { Total } & \$ 90,983.25 & \$ 98,397.75\end{array}$

(5) Total Cost using TEMPTITE or ROVANCO

\begin{tabular}{lrr} 
Wells to Heat Exchanger & $\frac{\text { TEMPTITE }}{\text { ROVANCO }}$ \\
$\begin{array}{l}\text { Heat Exchange to Hot } \\
\text { Water Storage Tank }\end{array}$ & $\$ 98,887.58$ & $\$ 109,876.08$ \\
$\begin{array}{l}\text { Hot Water Storage } \\
\text { Tank to Tunnels }\end{array}$ & $36,175.82$ & $\$ 91,577.42$ \\
$\begin{array}{l}\text { Tunnel System to } \\
\text { User Buildings }\end{array}$ & $\frac{90,983.25}{\$ 307,424.97}$ & $37,977.60$ \\
& $\$ 30,397.75$ \\
\hline
\end{tabular}

Cost Analysis, Other Materials in tunnel

(1) Tunnel system to users (2175 feet of 6-inch pipe and 2850 feet of 4-inch pipe), comparing standard steel versus Rovanco steel.

a. 6-inch steel pipeline (2175 feet)

\begin{tabular}{lcr} 
COST/FOOT & ROVANCO-S & STANDARD-S \\
\cline { 2 - 2 } & 19.90 & 6.25 \\
Installation & 13.15 & 13.15 \\
Burial & $-0-$ & 22.43 \\
Total/foot & 33.05 & 41.13 \\
Sub Total & $\$ 71,883.75$ & $\$ 90,980.25$
\end{tabular}


Table $V-1$ (continued)

b. 4-inch steel pipeline, (2350 feet)

\begin{tabular}{lrr} 
COST/FOOT & ROVANCO-S & STANDARD-S \\
\hline Material & 13.72 & 3.46 \\
Installation & 8.90 & 8.90 \\
Burial & $-0-$ & 29.36 \\
Total/foot & 22.62 & 29.36 \\
Sub Total & $\$ 64,467.00$ & $\$ 83,676.00$
\end{tabular}

c. Total cost, utility portion, comparing ROVANCO steel with standard steel

$\frac{\text { ROVANCO-S }}{\$ 136,350.75} \quad \frac{\text { STANDARD-S }}{\$ 174,656.25}$

(2) Total pipeline cost (using standard or ROVANCO steel in tunnels) vs. Temptite or ROVANCO for total system.

\section{Buried}

Utility tunnel

(1) TEMPTITE only

(2) ROVANCO only

(3) TEMPTITE and ROVANCO Steel

(4) TEMPTITE and STANDARD Steel

(5) ROVANCO and STANDARD Steel

\section{TEMPTITE}

$\$ 216,451.72$

$90,983.25$

ROVANCO-S

$\$ 239,431.10$ $\$ 136,350.75$

$=\$ 307,434.97$

$=\$ 337,828.85$

$=\$ 352,802.47$

$=\$ 391,107.97$

$=\$ 414,087.35$

STANDARD-S

$\$ 174,656.25$

.


Conclusions :

1. TEMPTITE apparently is the most cost effective.

2. Probable installed cost is as follows:

a. From previous calculations, pipeline is: $\$ 307,434.97$

b. Interconnecting portion .

(1) 20 ea MOA, 6-inch @ $\$ 92.95=\$ 1,859.00$

(2) 10 ea MOA, 4-inch \& $\$ 82.23=822.30$

(3) Installation cost @ $\$ 8.05 / \mathrm{ft} .=805.00$

c. From previous calculation, fitting cost $=10,054.48$

$\$ 320,975.75$

d. Bleed System cost is

$=\quad 2,596.98$

$\$ 323,572.73$

e. Contingency cost

$26,421.00$

TOTAL

$\$ 350,000.00$

3. A competitve manufacturer (Ameron BONDSTRAND) has submitted a price quotation and specifications which appear to be extremely competitive with TEMPTITE for the utility tunnel portion. Final procurement decision will be based on Total Installed Cost, life expectancy and maintenance considerations. 
HEAD LOSSES

In anticipation of the retrofit requirements to replace the steamheated domestic hot water system by a geothermal domestic hot water system, it is essential to consider any possible pressure differences in the individual buildings caused by changing the systems. The current system provides enough pressure in the hot water lines to deliver the water to the most distant hydraulic point in the individual building. The question is whether the geothermal system presently envisioned will be able to provide sufficient pressure in the hot water line to move the water to the most distant point.

In the determination of the deliverable pressure head at each building the following was taken into consideration: 1) the elevation head and 2) head losses due to the piping employed in the transportation of the water from the geothermal source to the building. The difference in elevation between the stored geothermally generated hot water (near the four million gallon water tank) and the individual campus buildings will give a positive pressure head. The head losses in the system will be generated due to the pipe used to carry the water. Pipe losses are calculated based on the size of the pipe used and the projected flow. The difference between the positive elevation head and the negative pipe losses will yield a deliverable head to each building.

Table $\mathrm{V}-2$ depicts the results of head loss calculations based on measured and estimated flow rates, the fluid friction losses for TEMPTITE or ROVANCO, and the surveyed construction profile for elevation head changes. 
Table $\mathrm{V}-2$

Transmission Pipeline Design Parameters

\begin{tabular}{|c|c|c|c|c|c|c|c|c|c|}
\hline EQUIPMENT & SEGMENT & $\begin{array}{c}\text { DISTANCE } \\
\text { (FEET) }\end{array}$ & $\begin{array}{c}\text { PIPE } \\
\text { DIAMETER } \\
\text { (INCIIES) } \\
\end{array}$ & $\begin{array}{l}\text { PEAK FLOW } \\
\text { (GPM) }\end{array}$ & $\begin{array}{c}\text { ELEVATION } \\
\text { CHANGE (FT) }\end{array}$ & $\begin{array}{l}\text { FRICTION } \\
\text { LOSS (FT) } \\
\end{array}$ & $\begin{array}{c}\text { PUMP } \\
\text { BOOST (FT) }\end{array}$ & $\begin{array}{l}\text { CUHULATIVE } \\
\text { HEAD (FEET) }\end{array}$ & $\begin{array}{c}\text { CONSUMED } \\
\text { FLOW (GPM) } \\
\end{array}$ \\
\hline Wells & $A-B$ & 1130 & 4 & 200 & +51 & -4 & +92 & 139 & \\
\hline & $C-D$ & 2306 & 6 & 200 & +55 & -8 & +35 & 86 & \\
\hline & $\mathbf{D}-\mathbf{E}$ & 1884 & 6 & 200 & +73 & $-66^{2}$ & & 93 & \\
\hline Heat Exchanger & & $\mathbf{0}$ & N/A & 200 & +20 & -34 & +35 & 21 & \\
\hline $\begin{array}{l}\text { Hot Water } \\
\text { Storage Tank }\end{array}$ & & 0 & N/A & 200 & 0 & 69 & & 4 & \\
\hline & $F-G$ & 1714 & 4 & 180 & -8 & -27 & $169^{3}$ & 138 & $(30)^{4}$ \\
\hline & G - II & 1600 & 4 & 180 & +21 & -26 & & 133 & 60 \\
\hline NORTH & H $-\mathbf{I}$ & 600 & 4 & 120 & +10 & -5 & & 138 & 70 \\
\hline LOOP & $\mathbf{I}-\mathbf{J}$ & 50 & 4 & 50 & +1 & -1 & & 138 & 20 \\
\hline SOUTH & $M-N$ & 450 & 6 & 165 & +9 & -1 & & 205 & 110 \\
\hline LOOP & $N-0$ & 600 & 4 & 55 & +10 & -1 & & 214 & 55 \\
\hline
\end{tabular}

NOTES

1) Flow is retricted across a valve to force gas separation.

2) Flow constricted to provide flow pressure balancing between geothermal loop and domestic cold water loop from main storage tank into the heat exchanger.

3) Pump boost will be controlled against cold water main to balance line pressures between cold and hot water lines.

4) Represents peak flow at time of day not coincident with daily composite peak.

5) Hot water storage tank is vented to atmospheric pressure. 


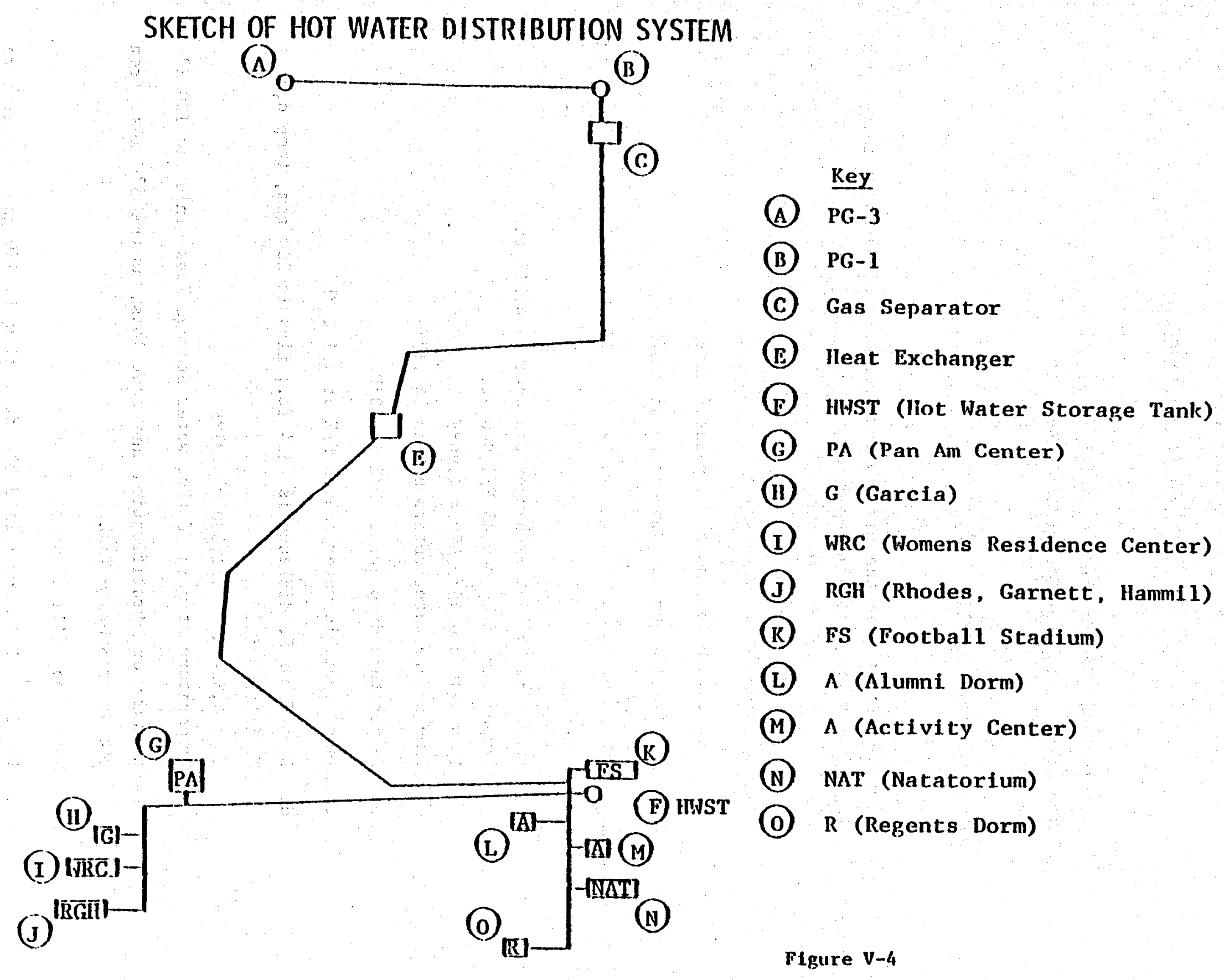


Table V-3

\section{Heat Loss Calculations}

(for reference, See Figure V-4, which is a sketch of the Hot Water Distribution System)

Heat losses for TEMPTITE

1. The temperature of the mixed water ( $P G-1$ and $P G-3$ ) as it leaves mix point at $\mathrm{PG}-1$ will be $145^{\circ} \mathrm{F}$.

2. Assumptions:

a. Temperature loss at gas separator, $2^{\circ} \mathrm{F}$

b. Flow is $200 \mathrm{gpm}$ at temperature of $143^{\circ} \mathrm{F}$

\section{Calculations}

a. From PG-1 to Heat exchanger distance is 4,216 ft.

Temperature drop $=0.45^{\circ} \mathrm{F} / 1,000 \mathrm{ft}$.

$\Delta \mathrm{T}=4216 \times 0.45 / 1,000=1.90^{\circ} \mathrm{F}$

Temp before water enters $\mathrm{H} / \mathrm{E}$ is $141.1^{\circ} \mathrm{F}$

b. Temperature drop across $\mathrm{H} / \mathrm{E}$ is $10^{\circ} \mathrm{F}$

c. Assume potable water leaves $\mathrm{H} / \mathrm{E}$ at $131.1^{\circ} \mathrm{F}$

d. Loop E to F; distance is $4334 \mathrm{ft}$. ; flow is $200 \mathrm{gpm}$, temp drop = $0.21 / 1,000 \mathrm{ft}$.

$\Delta \mathrm{T}=4,334 \times 0.21 / 1,000=0.91^{\circ} \mathrm{F}$

Temperature at point $\mathrm{F}$ (Hot water Storage Tank) inlet is $130.2^{\circ} \mathrm{F}$.

e. Because of stratification and heat loss, assume $5^{\circ} \mathrm{F}$ loss from Hot Water Storage Tank.

f. North Loop (Al1 4" pipe)

1) F to $\mathrm{H}$ distance is $3,314 \mathrm{ft}$; flow is $180 \mathrm{gpm}$, temperature drop $=0.13^{\circ} \mathrm{F} / 1,000 \mathrm{ft}$. 
$\Delta \mathrm{T}=3,314 \times 0.13 / 1,000=0.44^{\circ} \mathrm{F}$

Temperature point H (Garcia Dorm) is $125.2-0.44$, or $124.76^{\circ} \mathrm{F}$

2) H to I distance is $600 \mathrm{ft}$, flow is $120 \mathrm{gpm}$, temperature drop $=0.20^{\circ} \mathrm{F} / 1,000 \mathrm{ft}$.

$\Delta \mathrm{T}=600 \times 0.20 / 1,000-0.12^{\circ} \mathrm{F}$

Temperature at point I (WRC) is $124.76-0.12$, or $124.64^{\circ} \mathrm{F}$

3) I to $\mathrm{J}$, distance is $50 \mathrm{ft}$, flow is $50 \mathrm{gpm}$, temp drop = $0.45^{\circ} \mathrm{F} / 1,000 \mathrm{ft}$

$\Delta \mathrm{T}=50 \times 0.48 / 1,000=0.02^{\circ} \mathrm{F}$

Temperature at point $J$ (Rhodes Hall) is $124.64-0.02$, or $124.62^{\circ} \mathrm{F}$

g. South Loop (predominantly 6" pipe)

1. F to $\mathrm{K}$ distance is $200 \mathrm{ft}$, flow is $180 \mathrm{gpm}$, temperature drop $=0.13^{\circ} \mathrm{F} / 1,000 \mathrm{ft}$.

$\Delta \mathrm{T}=200 \times 0.13 / 1,000=0.03^{\circ} \mathrm{F}$ at point $\mathrm{K}$, temperature is $125.2-0.03$, or $125.17^{\circ} \mathrm{F}$

2. $K$ to $M$, distance is $1,725 \mathrm{ft}$. flow is $240 \mathrm{gpm}$, temp drop $=0.20^{\circ} \mathrm{F} / 1,000 \mathrm{ft}$.

$\Delta \mathrm{T}=1,725 \times 0.20 / 1,000=0.35^{\circ} \mathrm{F}$

at point $M$ (Activity Center) temperature is $125.17-0.35$

or $124.82^{\circ} \mathrm{F}$

3. $M$ to $\mathrm{N}$, distance is $450 \mathrm{ft}$. flow is $165 \mathrm{gpm}$, temp drop $=0.29^{\circ} \mathrm{F} / 1,000 \mathrm{ft}$.

$\Delta \mathrm{T}=450 \times 0.29 / 1,000=0.13^{\circ} \mathrm{F}$

at point $N$ (Natatorium) temperature is $124.82-0.13$, or $124.7^{\circ} \mathrm{F}$. 
Table V-3 (continued)

4. N to 0 , distance is $600 \mathrm{ft}$. flow is $55 \mathrm{gpm}$, temp. drop $=0.43^{\circ} \mathrm{F} / 1,000 \mathrm{ft}$.

$\Delta \mathrm{T}=600 \times 0.43 / 1,000=0.26^{\circ} \mathrm{F}$

at point $\mathrm{O}$ (Regents $\mathrm{Hall}$ ) temperature is $124.7-0.26$, or $124.45^{\circ} \mathrm{F}$

4. The previous calculations are for peak flow conditions. A design conclusion is that, given the validity of assumptions concerning probable heat loss in the gas separator, the heat exchanger, and the hot water storage tank, the system can deliver hot water to end users at $120-125^{\circ} \mathrm{F}$ under peak flow conditions. The worst case is the condition that exists during night time and holiday usage, when a minimum flow of $20 \mathrm{gpm}$ is expected. Using the methodology for peak flow conditions, the following table depicts possible end-use temperature under minimum flow conditions. 
Table $\mathrm{V}-4$

Temperature Loss, Minimum Flow Condition $(20 \mathrm{gpm})$

$\begin{array}{llccc}\text { From: } & \begin{array}{l}\text { Segment } \\ \begin{array}{l}\text { Storage Tank } \\ \text { to Rhodes }\end{array}\end{array} \underbrace{\text { Temp }\left({ }^{\circ} \mathrm{F}\right)} & \frac{\begin{array}{c}\text { Temp } \\ \text { Loss }\left({ }^{\circ} \mathrm{F}\right)\end{array}}{125.2} & 4.72 & \begin{array}{c}\text { End-Use } \\ \text { Temperature }{ }^{\circ} \mathrm{F}\end{array} \\ \text { From: } & \begin{array}{l}\text { Storage Tank } \\ \text { to Regents }\end{array} & 125.2 & 120.5 & \\ & & 5.93 & 115.2\end{array}$

These calculations are predicated on a bleed system which would allow a small volume of water to be siphoned from the building hot water circulation loop, and routed to a separate bleed water disposal system, which also would connect with the exit water from the outdoor pool heat exchange. In aggregate, building bleed off would total $80 \mathrm{gpm}$ in the four to six hour period when night time usage is at a minimum. 
As can be seen, the probably end-use temperature at Regents Dorm is approximately $115^{\circ} \mathrm{F}$. This is the expected temperature in the middle of the night, during a portion of the year when the outdoor pool heat exchanger is not required to be in service. Even this low temperature, however, is well above the $108^{\circ} \mathrm{F}$ temperature required for showers and lavatories. Even then, the system will respond with increased temperatures when peak flow conditions are experienced at 6:00-7:00 am daily. Thus, there appears to be minimal risk of students being exposed to cold showers when the system is operational.

One other area of concern is temperature stratification. (See also the discussion in Section VII of this report.) The design incorporates several features to attempt to overcome this stratification, to include a bottom manifold inlet, a recirculating system with bottom manifold inlet, and a floating head intake for the in-line circulating pump. With these design features acting in concert to provide constant mixing of the 20,000 to 60,000 gallons of water in the tank, stratification can be minimized. During prolonged low demand periods, however, such as Christmas vacation, it is possible that the system will require a temperature "charge" through use of a large volume bleed, or a one-shot boost from the stand-by natural gas fired boilers. 
Table V-5

Cost Estimates Fittings for Transmission Pipeline

SIZE

UNIT PRICE UNIT PRICE QTY.* TEMPTITE ROVANCO

4" $90^{\circ} \mathrm{EL}$

25.88

50.00

15

250.00

129.40

4 4" $45^{\circ} \mathrm{EL}$

25.88

47.00

15

235.00

129.40

4" TEE

32.20

74.00

296.00

128.00

4" FLANGE

16.44

30.00

600.00

328.80

4" REDUCER

52.79

70.00

280.00

211.16

6" $90^{\circ} \mathrm{E}$

70.80

69.10

8

552.80

566.40

6" $\quad 45^{\circ} \mathrm{EL}$

70.80

62.48

3

187.44

212.40

6" TEE

92.80

102.00

8

816.00

741.52

6" FLANGE

32.50

90.00

19

$1,710.00$

617.50

6" REDUCER TEES 72.33

120.00

5

$\frac{600.00}{\$ 5,527.24} \frac{361.65}{\$ 3,427.03}$

Assuming insulation and installation of the insulation will double cost.

Total Estimate

$\underline{\$ 10,054}$

$\$ 6,854$ 


\section{BLEED SYSTEM}

\section{General}

Thus far, design factors have considered only the existing openloop system, which transports domestic hot water to the 12 target buildings end users. However, a further modification is necessary in order to avoid a system "lock-up" condition during night-time limitedusage periods. This "lock-up" condition is of concern, because maximum temperature losses will occur when the system is at low or zero-flow condition. Hence, a system of low-volume bleeds is envisioned, which would provide a minimum flow of at least ten gallons per minute through each of the target buildings. The various bleed systems would be interconnected and would discharge into the campus irrigation water system. In addition, the system would capture the used hot water from a separate heat exchanger for utilization in warming the outdoor swimming pool. In concept, the bleed system lines would be uninsulated, lowestcost piping, which would consequently require minimal installation and maintenance costs.

Estimated Cost of Bleed System Materials

$5000 \mathrm{ft}$. of 2 -inch PVC pipe C 50\%/ft.: $\$ 2,500$

12 tees @ $\$ 1.79$ each:

50 ells @ $\$ 1.51$ each: 75

Total 
Table V-6

\section{Technical Specifications, Johns-Manville TEMPTITE}

Pipe: Epoxy lined asbestos - cement lined corrisive resistant pipe. Asbestos cement pipe will be light, rugged autoclaved cured. Pipe must be able to withstand application up to $210^{\circ} \mathrm{F}$.

Insulation: Polyurethane foam bonded between a lined casing and core. Must be able to be capped at both ends with water and heat resistant end seals to ensure complete encasement... to maintain high thermal efficiency. $1 \frac{1}{2}$ inch minimum thickness.

Epoxy lining - shall be composed of a $100 \%$ solids system, containing no solvents or diluents. The lining shall be centrigufally cast onto the interior core pipe wall to produce a continuous film of uniform thickness containing no uncoated areas, no thin spots, no runs, and no sags. The complete system shall be cured for 30 minutes at a temperature of between $170^{\circ} \mathrm{F}$ and $200^{\circ} \mathrm{F}$. A dye may or may not be used to color the lining.

$\begin{array}{ll}\text { Lining Properties: } & \\ \text { Lining adhesion } & 400 \mathrm{psi} \\ \text { Hazen-Williams C value } & 150 \mathrm{p} \\ \text { Temperature limitations } & 35^{\circ} \mathrm{F}-210^{\circ} \mathrm{F} \\ \text { Minimum lining Barcol hardness } & 40 \\ \text { Minimum lining thickness } & 12 \mathrm{mils} \\ \text { Modulus of elasticity } & 0.7 \times 10 \mathrm{psi} \\ \text { Tensile strength (min.) } & 10,000 \mathrm{psi} \\ \text { Elongation at tensile failure } & 0.7 \text { to } 1.7 \% \\ \text { Operating Pressure } & 0-150 \mathrm{psi} \\ \text { Conductivity } \mathrm{k} \text { value } & 0.16\end{array}$


Fittings: All fittings shall be cast iron pressure fittings RING-TITE bells conforming to AWWA standard $c-110$ or welded steel fusion coated epoxy lined with Ring-Tite mechanical ends per AWWA-C201, C-209 modified, C-207, C-206.

Vapor barrier - autoclave cured asbestos - cement ensuring complete seal of insulation from outside water and moisture.

\begin{tabular}{|c|c|c|c|c|}
\hline \multicolumn{2}{|c|}{ Nominal diameter } & \multirow[t]{2}{*}{ Standard lengths } & \multicolumn{2}{|c|}{ Weight } \\
\hline in. & $\mathrm{mm}$ & & $1 \mathrm{~b} / \mathrm{ft}$ & $\mathrm{kg} / \mathrm{m}$ \\
\hline 3 & 80 & $10^{\prime}$ & $13.2^{\frac{x}{x}}$ & $19.8^{\frac{t}{t}}$ \\
\hline 4 & 100 & $10^{\circ}$ & $19.3^{\circ}$ & $28.95^{*}$ \\
\hline 6 & 150 & $13^{\prime}$ & $23.1^{*}$ & $34.65 *$ \\
\hline 8 & 200 & $13^{\prime}$ & $39.9 *$ & $59.85 *$ \\
\hline
\end{tabular}

Short lengths (I)

\begin{tabular}{ccc} 
MOA & MEE \\
\hline $3^{\prime \prime}$ & $3^{\prime}-3^{\prime \prime}$ & $6^{\prime}-9^{\prime \prime}$ \\
$4^{\prime \prime}$ & $3^{\prime}-3^{\prime \prime}$ & $6^{\prime}-9^{\prime \prime}$ \\
$6^{\prime \prime}$ & $6^{\prime}-6^{\prime \prime}$ & $6^{\prime}-6^{\prime \prime}$ \\
$8^{\prime \prime}$ & $6^{\prime}-6^{\prime \prime}$ & $6^{\prime}-6^{\prime \prime}$ \\
$* \quad$ including coupling
\end{tabular}


Technical Specifications, Ameron BONDSTRAND

Pipe: Filament-wound using continuous glass filaments and epoxy resins to provide a strong, uniform matrix through the entire wall. Pipe must be able to withstand application up to $210^{\circ} \mathrm{F}$.

Insulation: Polyurethane foam bonded between a lined casing and core. Must be able to be capped at both ends with water and heat resistant end seals to ensure complete encasement ... to maintain high thermal

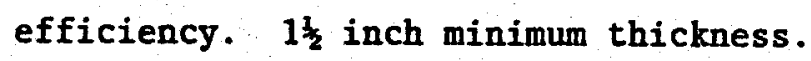

Epoxy lining: Due to the properties of the BONDSTRAND an epoxy lining is not required.

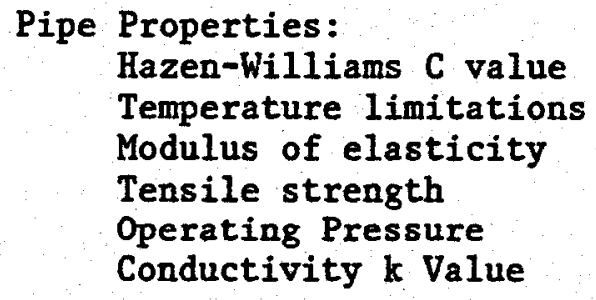

Pipe Properties:

Hazen-Williams C value Temperature limitations Modulus of elasticity Operating Pressure Conductivity k Value

Fittings: all fittings shall be manufactured of the same material as the pipe, meeting the same specifications.

Vapor barrier - aluminum outer casing ensuring complete seal of insulation from outside water and moisture. 
Table V-7 (continued)

Pipe sizes and weights

\begin{tabular}{crrrr}
\multicolumn{2}{r}{ Nominal diameter } & Standard lengths* & \multicolumn{2}{c}{ Weight } \\
\hline in. & $\mathrm{mm}$ & & \multicolumn{1}{c}{ lb/ft } & $\mathrm{kg} / \mathrm{m}$ \\
\hline 2 & 50 & $30^{\circ}$ & 0.8 & 1.2 \\
3 & 80 & $30^{\circ}$ & 1.2 & 1.8 \\
4 & 100 & $30^{\circ}$ & 1.9 & 2.8 \\
6 & 150 & $30^{\circ}$ & 3.0 & 4.5 \\
\hline
\end{tabular}

* These lengths can be ordered from factory also in $10^{\prime}$ and $20^{\prime}$, but due to ease of field cutting this may or may not be taken advantage of. 


\section{GAS SEPARATOR DESIGN}

\section{General}

During the ten-day test in July 1980, observations were made of the fact that small gas bubbles were separating from the fluid at the discharge pipe. The pump supplier attributed sub-standard pump performance to the presence of gas in the geothermal water. The possible presence of this gas, moreover, poses a major problem to efficient heat exchanger operation, because the gas will tend to separate in the heat exchanger because of pressure and temperature drops, thus resulting in two-phase flow. Even if the gas is vented continuously, a sharply reduced heat exchanger efficiency could result.

\section{Description of Data}

Controlled experiments were conducted on 23 October, and again on December 16, 1980, to acquire gas and water samples for analysis, and to determine gas flow rates. Data acquired is depicted in Table VI-1. A sketch of the field test set-up is contained in Figure VI-1. 
Table VI-1

Gas Collection Rate Tests Dec. 16, 1980

(after pump was reinstalled with downhole gas separator)

\begin{tabular}{|c|c|c|c|c|c|c|c|c|}
\hline TIME & $\begin{array}{c}\text { PRESSURE } \\
1\end{array}$ & $\begin{array}{l}\text { PRESSURE } \\
2\end{array}$ & $\Delta P$ & TIME & $\begin{array}{l}\text { FLOW } \\
\text { (GPM) }\end{array}$ & $\begin{array}{l}\mathrm{H} \\
\text { (IN) }\end{array}$ & $\begin{array}{c}\text { VOL } \\
\left(\mathrm{IN}^{3}\right)\end{array}$ & $\begin{array}{c}\text { RATE } \\
\left(\mathrm{IN}^{3} / \mathrm{MIN}\right)\end{array}$ \\
\hline \multirow[t]{4}{*}{$7: 30 \mathrm{AM}$} & 70 & 2 & 68 & $6 \mathrm{~min}$ & 156 & $30^{\prime \prime}$ & 235.5 & 47.1 \\
\hline & 75 & 6 & 69 & $12 \mathrm{~min} 45 \mathrm{sec}$ & $=136$ & $15^{\prime \prime}$ & 117.75 & 9.24 \\
\hline & 70 & 10 & 60 & $10 \mathrm{~min}$ & 156 & $2^{\prime \prime}$ & 15.7 & 1.57 \\
\hline & 47 & 3 & 44 & $6 \mathrm{~min} 18 \mathrm{sec}$ & $=187$ & $30^{\prime \prime}$ & 235.5 & 37.3 \\
\hline $8: 30$ & 48 & 5 & 43 & $24 \mathrm{~min}$ & 179 & $30^{\prime \prime}$ & 235.5 & 9.8125 \\
\hline $11: 15$ & 47 & 2 & 45 & $3 \mathrm{~min} 37 \mathrm{sec}$ & $=188$ & $30^{\prime \prime}$ & 235.5 & 65.12 \\
\hline $11: 20 A M$ & 15 & 2 & 13 & $33 \mathrm{~min} 15 \mathrm{sec}$ & 213 & $27^{\prime \prime}$ & 211.95 & 6.374 \\
\hline & & $V=\frac{D^{2}}{4}$ & & & & & & \\
\hline
\end{tabular}

Pressure 1: Pump back-pressure

Pressure 2: Pressure on down-stream side of expansion valve

Time: Time duration of test

H: Height of gas in gas-separator trap 
Use was made of a specially manufactured gas trap, fabricated and installed per Figure VI-1. In order to collect gas in the gas separator, the geothermal fluid flow rate was constricted to establish a back pressure in the system of approximately $40 \mathrm{psig}$. (This is equivalent to expected normal system operating pressure.) The constriction valve then acts as an expansion valve, allowing the fluid to transition sharply from 40 psig to roughly $2-4$ psig. This large pressure differential causes rapid expansion, hence separation, of the gas.

Initially, the gas accumulation rate at 4 psig was approximately 15-20 $\mathrm{in}^{3} / \mathrm{min}$, but this rate increased to $30 \mathrm{in}^{3} / \mathrm{min}$. when the flow was diverted to bypass the turbine flowmeter. The conclusion reached was that the rapidly moving turbine blades acted to homogenize the fluid so that the entrained gas bubbles were so finely divided so as to reduce effective separation of the gas from the water.

At a geothermal fluid flow rate of $170 \mathrm{gpm}$, the gas separator collected gas at a rate of 30 cubic inches per minute at 4 psig. The gas fraction in the fluid is then calculated as follows:

$\begin{aligned} \frac{\text { Gas Volume }}{\text { Fluid Volume }} & =\frac{30 \mathrm{in}^{3} \div 1728 \mathrm{in}^{3} / \mathrm{ft}^{3}}{170 \mathrm{gal} \times 7.48 \mathrm{ft}^{3} / \mathrm{gal}^{2}} \\ \text { Gas Fraction } & =0.00136 \% \text { at } 4 \mathrm{psig}\end{aligned}$

Water and gas samples were collected. Gas samples were acquired by two methods. Use was made of the gas trap, and four containers were filled. 


\section{NMSU CAMPUS GEOTHERMAL WELL \\ SCHEMATIC OF GAS SEPARATOR}

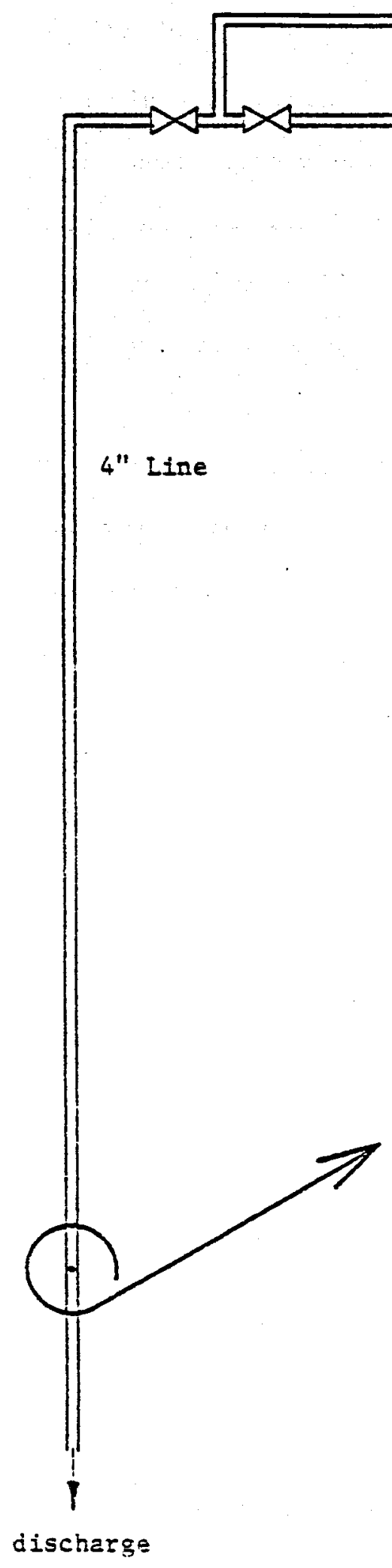

PUNP

HOUSE

Detalled Schematic

Gas Separa:or

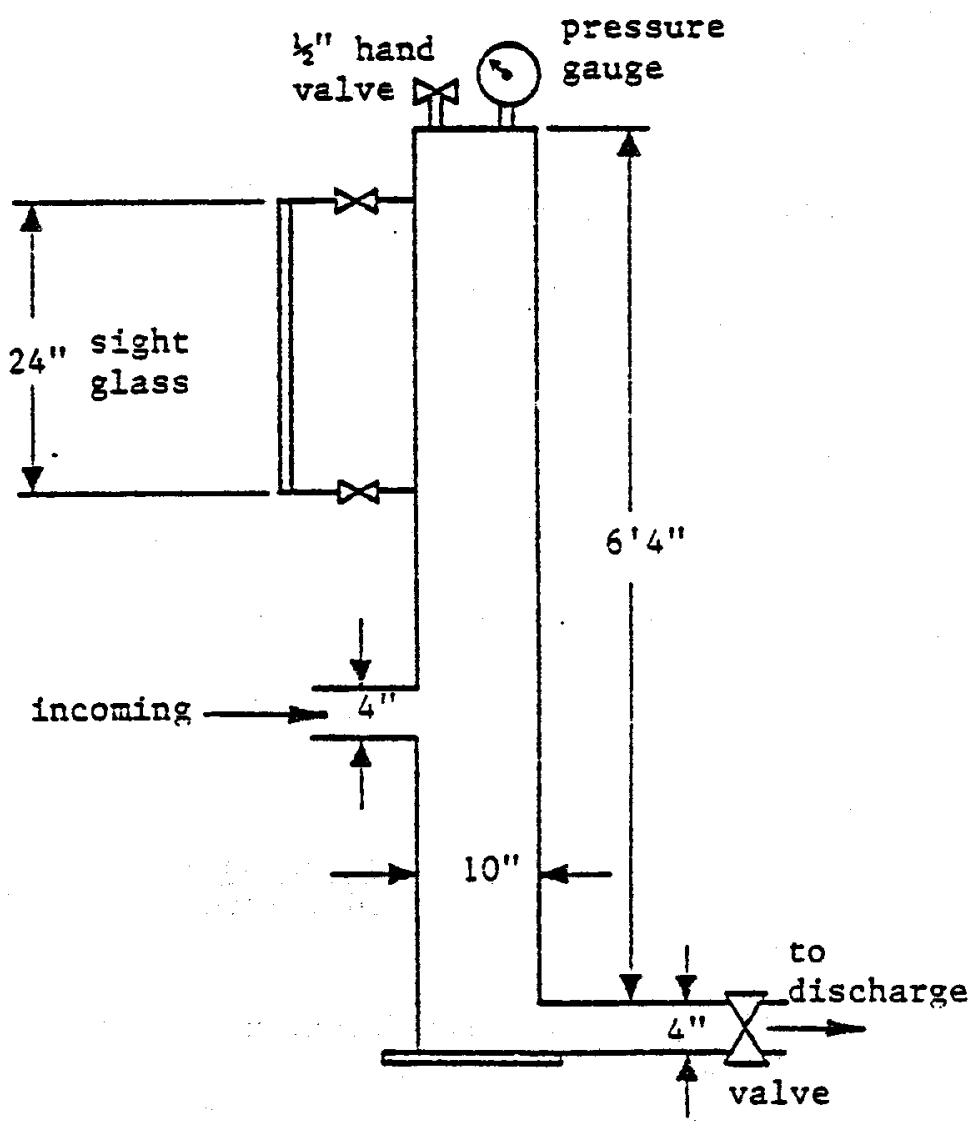

Figure VI-1 
In addition, a pressure vessel was evacuated to minus 26 inches of mercury, and was then filled by connecting it to the gas separator. This pressure vessel contained roughly 26 cubic feet of gas at 24 psig.

From the behavior of the gas separator mechanisms, our theory is that the gas is in solution in the water under pressure from the hydrostatic head. Part of this pressure is released as the water is passed through the 17 stages of the pump, by action of the pump impellors. At ground surface, when the fluid experiences a sudden drop in pressure the gas separates from the water.

A rough approximation of this underground pressure can be calculated based on hydrostatic pressures. By assuming the geothermal water originates from a zone at the mid-point of the well screen, the approximate hydrostatic pressure is as defined in Table VI-2.

Table, VI-2

Geothermal Well Field Subsurface Pressures

static Water Depth to Mid-point Net Hydrostatic Sub-surface Well level (feet) of screen (feet) Head (feet) Pressure (psia)

$\begin{array}{lllll}\text { PG-1 } & 328 & 775 & 447 & 165-235 \\ \text { PG-3 } & 382 & 800 & 418 & 140-225\end{array}$

Hence, the sub-surface liquid contains dissolved gas under high pressure. When this pressure is released, the compressible gas will tend to separate from the non-compressible liquid. 


\section{Follow-on Analyses}

a. Gas Composition. Gas samples were analyzed by three methods; namely gas chromatograph, mass spectrometer, and molecular analysis. Results from a gas chromatograph analysis performed by Dr. Gary Eiceman of NMSU indicate the dissolved gas (collected after separation from the liquid) has the following composition.

\section{Table VI-3}

Gas Composition, Separated from Liquid

$\begin{array}{ccc}\frac{\text { Gas }}{\mathrm{N}_{2}} & \frac{\% \text { by volume (range) }}{4 \text { by volume (mid-point) }} & \frac{\%}{\mathrm{CO}_{2}} \\ \mathrm{O}_{2} & 45.5-47.2 & 46.02 \\ \mathrm{He} & 52-57 & 54.88 \\ & (\text { trace) } & \text { (trace) }\end{array}$

b. A pressurized water sample also was obtained by a researcher Carl Bernhardt, from New Mexico Institute of Mining and Technology. He analyzed samples for the amount of gas remaining in solution, prior to the pressure differential separation mechanism. Two samples were analyzed from Well PG-1, and one sample from PG-2 (President's Well). Results of this analysis are contained in Table VI-4. 
Table VI-4

Gas Composition, Dissolved in Liquid

(Preliminary Values)

Composition, moles per liter

Composition $\mathrm{mg} / \mathrm{l}$

$\begin{array}{llllllll}\text { Gas } & \text { PG-1(非)* } & \text { PG-1(非) } & \text { PG-2 } & \text { PG-1(非)* } & \text { PG-1(非) } & \text { PG-2 } \\ \mathrm{CO}_{2} & 8 \times 10^{-4} & 8.5 \times 10^{-3} & 7.3 \times 10^{-3} & 352 & 374 & 321 \\ \mathrm{~N}_{2} & 3.3 \times 10^{-4} & 5.2 \times 10^{-4} & 5.2 \times 10^{-3} & 9.24 & 14.56 & 14.56 \\ \text { Argon } & 6.4 \times 10^{-6} & 8.5 \times 10^{-6} & 9.3 \times 10^{-6} & 0.256 & 0.34 & 0.372 \\ \text { Neon } & 5.2 \times 10^{-6} & 4.7 \times 10^{-6} & 7.1 \times 10^{-6} & 0.105 & 0.188 & 0.284 \\ \text { Helium } & 1.3 \times 10^{-6} & 5.1 \times 10^{-6} & 5.2 \times 10^{-6} & 0.005 & 0.0204 & 0.0208 \\ 0_{2} & 6.6 \times 10^{-7} & 1.3 \times 10^{-6} & 7.2 \times 10^{-7} & 0.021 & 0.042 & 0.023 \\ \text { Krypton } 4.8 \times 10^{-10} & 5.1 \times 10^{-10} & 3.1 \times 10^{-10} & 4.0 \times 10^{-5} & 4.3 \times 10^{-5} & 2.6 \times 10^{-5}\end{array}$

* Sample \#1 from PG-1 had been allowed to stand for several hours in a glass bottle, and it is believed that part of the gases escaped.

c. From theoretical inorganic carbon and $\mathrm{pH}$ analysis of the fresh geothermal fluid, considering dissolved and suspended materials, the pressurized water should contain approximately $150 \mathrm{mg} / 1$ of $\mathrm{CO}_{2} \mathrm{gas}$, plus carbon tied up in bicarbonates and carbonic acid. This amount of $\mathrm{CO}_{2}$ is consistent with the estimate based on total molecular carbon present, but is lower than the actual values measured by Carl Bernhardt. It is reported that some $\mathrm{CO}_{2}$ is lost to the atmosphere before the analysis. This is reflected in a steady $\mathrm{pH}$ increase until equilibrium is reached. (The $\mathrm{pH}$ of the solution increases from an initial 6.80 to approximately 8.35 at equilibrium). Hence, the expected amount of $\mathrm{CO}_{2}$, which will separate at the gas separator, is in the range of $130-150 \mathrm{mg} / 1$.

d. From the controlled gas-separation tests conducted using the apparatus depicted in Figure VI-1, several conclusions have been 
formulated. Figure VI-2 is a plot of gas separation rate versus back pressure. Also depicted by a star is the single datum obtained before the down-hole gas separator was installed. This gas separator was recommended by the pump supplier as needed to improve pump efficiency, and to facilitate gas separation. From available data as depicted in Figure VI-2, the down-hole gas separator appears to offer negligible improvement in controlling gas separation, since the gas generation rate at the surface remained effectively unchanged by the use of the gas separator. Also of significance, the energy required to pump the water thru the down-hole separator resulted in a small but significant decrease in overall pump efficiency. For design purposes, the controlled experiments lead to the conclusion that an increase in back pressure, and a corresponding increase in the magnitude of the pressure drop across the orifice (constriction valve) will result in maximizing the rate of gas separation. From the data, the rate of gas separation is more strongly affected by the size of the pressure drop, but the best rate of separation is obtained where the final pressure is slightly above atmospheric pressure. If these conclusions are correct, the desired state is to obtain a back pressure at the entrance to the gas separator of 80 to 100 psig (consistent with overall energy needs of the well pump needed to provide this back pressure) and to allow the fluid to rapidly expand to atmospheric pressure. 


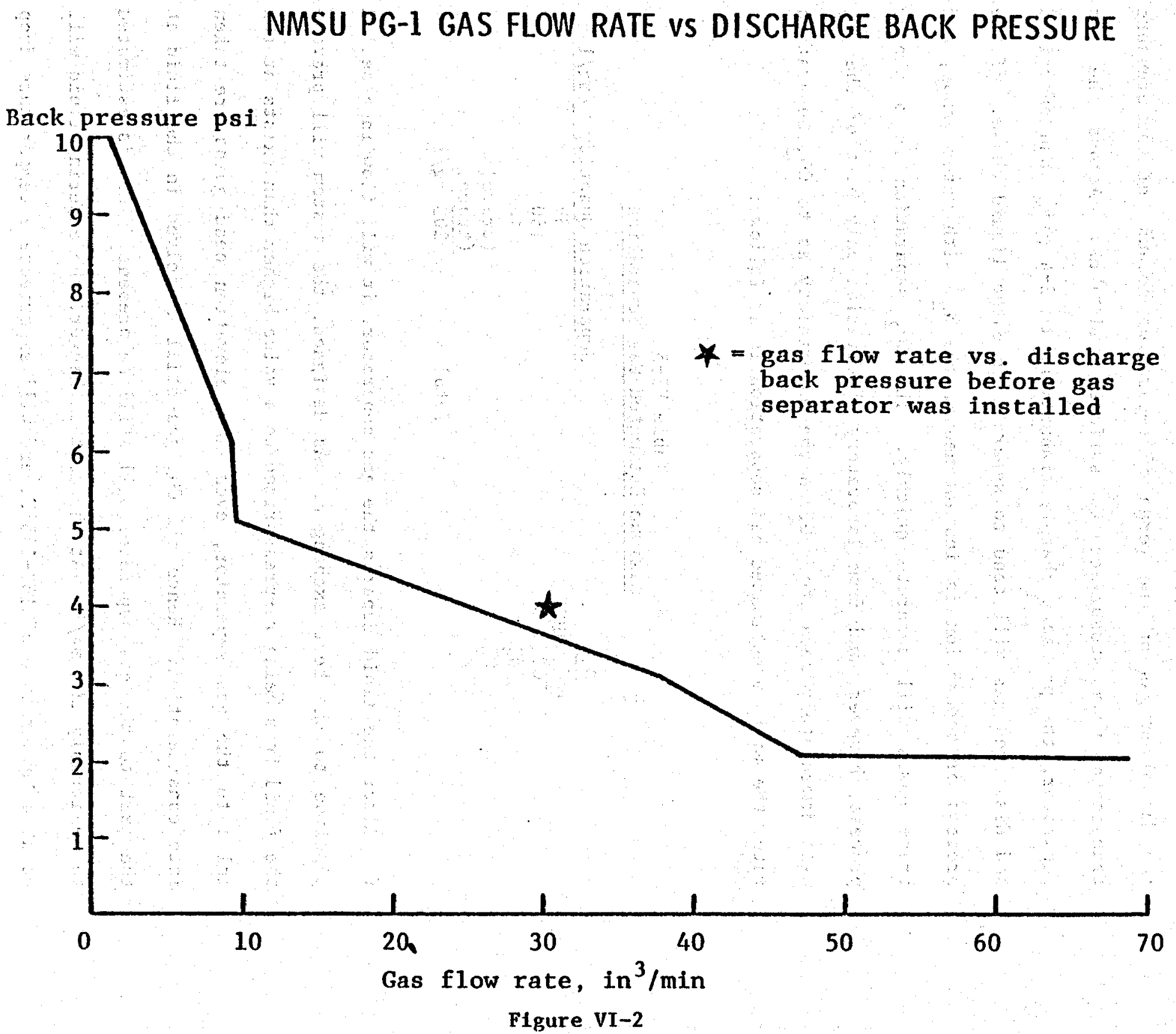


e. At the gas separator, the entering fluid is water at roughly 80 psig, with some of the dissolved gas already separated, and the rest of the dissolved gas on the verge of separation because of the pressure transition from subsurface to surface conditions. Across the gas separator, the pressure sharply transitions to $2-4 \mathrm{psig}$, and entrained and dissolved gas will tend to separate from the liquid phase. If the process of separation is instantaneous, the $\mathrm{N}_{2}$, with water vapor, and trace gases will separate quickly. The $\mathrm{CO}_{2}$ separation is a slower process, however, and from laboratory observation only part of the $\mathrm{CO}_{2}$ will immediately separate. Given the uncertainty as to $\mathrm{CO}_{2}$ separation rate, the maximum estimated gas separation is as follows:

Table VI-5

Maximum Estimated Gas Separation
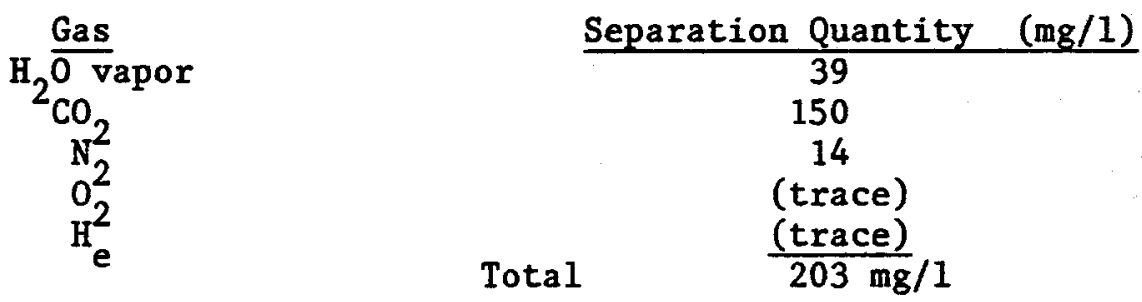

f. After the fluid departs the gas separator, it will flow in a sealed pipeline to the heat exchanger. As designed, the system will prevent the fluid from being re-pressurized to a value higher than exists at the inlet to the gas separator, even when elevation head gains are taken into consideration. Hence all $\mathrm{CO}_{2}$ gas still dissolved in the fluid at the exit to the gas separator will still be present. This is estimated to be roughly $200 \mathrm{mg} / \mathrm{l}$. At the heat exchanger, the entering fluid will be at a temperature of $140-145^{\circ} \mathrm{F}$, and will experience a temperature drop of approximately $70^{\circ} \mathrm{F}$ and a pressure drop of 15 psig. Since $\mathrm{CO}_{2}$ solubility decreases with the pressure drop, and increases with 
temperature drop, the net effect must be a combination of the two offsetting tendencies.

The solubility increase resulting from cooling the water is an order-ofapproximately three times as large as the solubility decreases attributable to the pressure drop across the heat exchanger. Hence, the $\mathrm{CO}_{2}$ will tend to remain in solution, thus precluding two-phase flow across the exchanger.

8. Follow-on tests. As part of the aquifer evaluation, and also to facilitate examination of the gas separation hypothesis, a second major test of the well pump is planned. This test will consist of an auxiliary engine, which should permit pumping at a rate of up to $350 \mathrm{gpm}$ with 40 psig back pressure, or higher back pressure at reduced flow rates. This equipment is designed to provide a back pressure of at least 60 psig at a flow rate of $200 \mathrm{gpm}$. These parameters are specified because the final design specifies a needed flow rate of $200 \mathrm{gpm}$, and the back pressure must be high enough to permit maximum gas separation. This test will be conducted in May or early June 1981.

\section{Design of Gas Separator Mechanism \\ a. Design Parameters}

(1) The tank should be of significant volume to handle $200 \mathrm{gpm}$ of fluid, and retain sufficient vapor volume to facilitate gas separation.

(2) Constant liquid volume should be available to provide a water level at a minimum of four feet of water over the pump suction on the discharge line. 
(3) Since the tank should be maintained slightly above atmospheric pressure, a gas vent valve system must be installed to allow gas to vent freely from the system.

(4) The tank will handle flow from either well, and provision must be made for well pump cut-off if the liquid level rises above a preset maximum.

(5) Elevation head will be available from the outlet of the gas separator to the heat exchanger, so that the pressure drop across the heat exchanger can be accommodated. However, minor fluctuations in well pump output, and the need to provide constant head above the gas separator discharge, necessitate a small in-line pump.

(6) It is desirable that all, or as many as practicable, of the controls and mechanical items be co-located. The logical and desirable location is immediately adjacent to the gas separator.

(7) The gas separator and attendant valve and fittings must be insulated, and buried. This burial is both for insulation purposes, elevation head purposes, and esthetic reasons.

\section{b. Preliminary Design}

(1) An epoxy coated interior, steel tank, 12 feet in diameter and 6 feet long will satisfy the minimum requirements. This tank will be buried with the 12-foot axis vertical. Figure VI-3 is a simplified drawing of this installation. The tank will be insulated with 2-inches of polyurethane foam sprayed on before burial. Vapor barriers will be Diathon or equivalent.

(2) The tank will be installed adjacent to the pump house for well PG-1, and located approximately 30 feet to the west, alongside Geothermal Road. Taking advantage of natural terrain features, the elevation will 
minimize burial depth requirements for the gas separator discharge lines which must exit approximately eleven feet below normal grade.

(3) To facilitate location of controls, for insulation purposes, and for physical security, the tank will be enclosed by an equipment well on one end. This well is 12 feet wide, 12 feet deep, and 12 feet long. Access will be through a roof hatch. The bottom and three side walls will be pre-cast (tilt-slab) concrete, coated with a vapor barrier before installation. The fourth wall, abutting the gas separator tank, will be concrete block. All pumps, pneumatic valves, connections to both wells, and gas separator inlet and outlet pipes will be located in the equipment well. In addition, an inspection port for the gas separator will be accessible from the equipment well.

(4) Concerning controls, Figure VI-3 and VI-4 are a schematic of the system, depicting major controls. Not depicted are manual isolation valves, check valves, and other minor system controls. Those will be finalized as part of the procurement package.

(5) This preliminary design will be reviewed and refined as necessary and appropriate following completion of the final gas separator test in May, 1981. 


\section{GAS SEPARATOR}
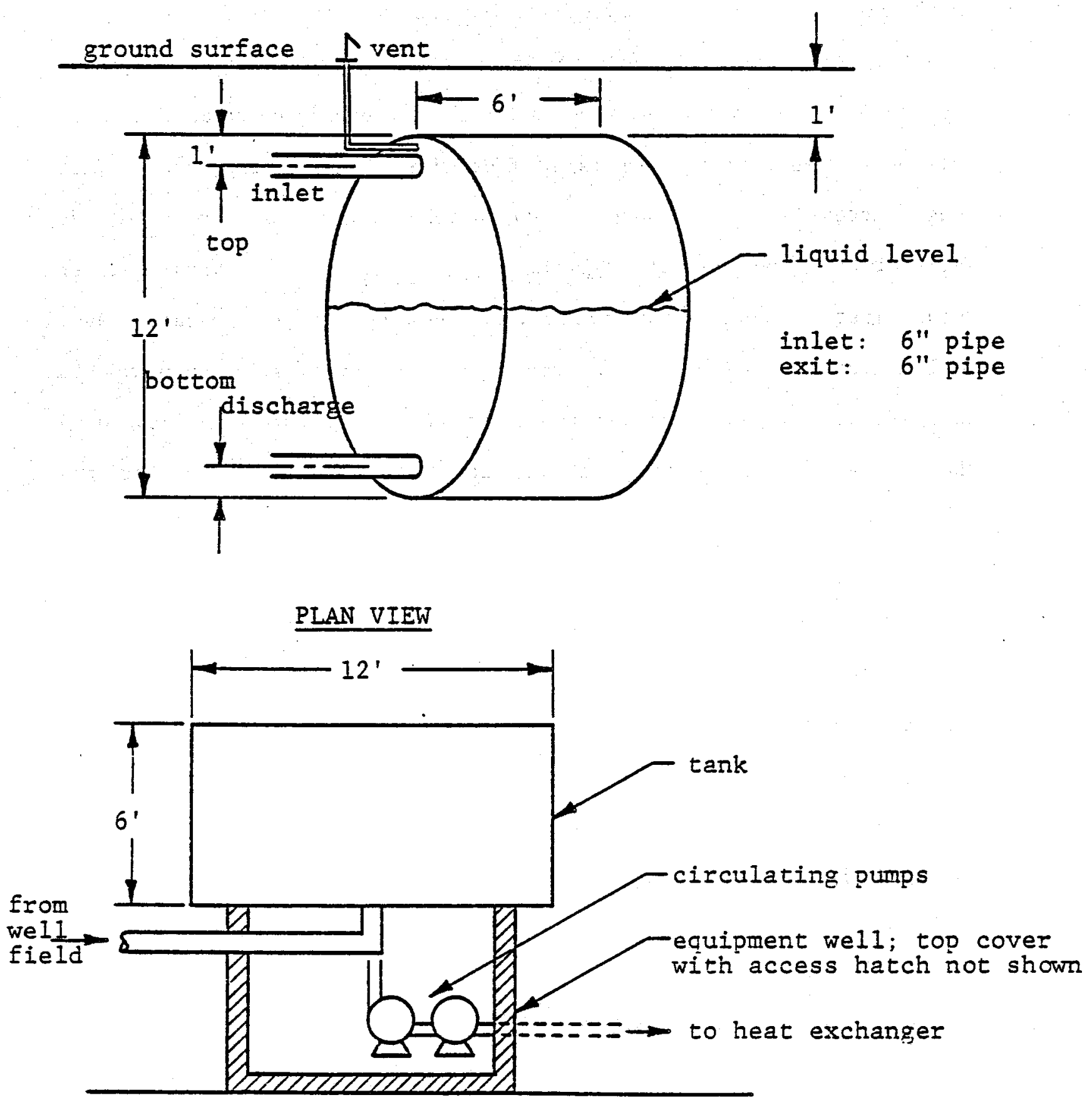

Geothermal Drive

Figure VI-3 


\section{DETAILS OF CONTROLS OF GAS SEPARATOR SYSTEM}

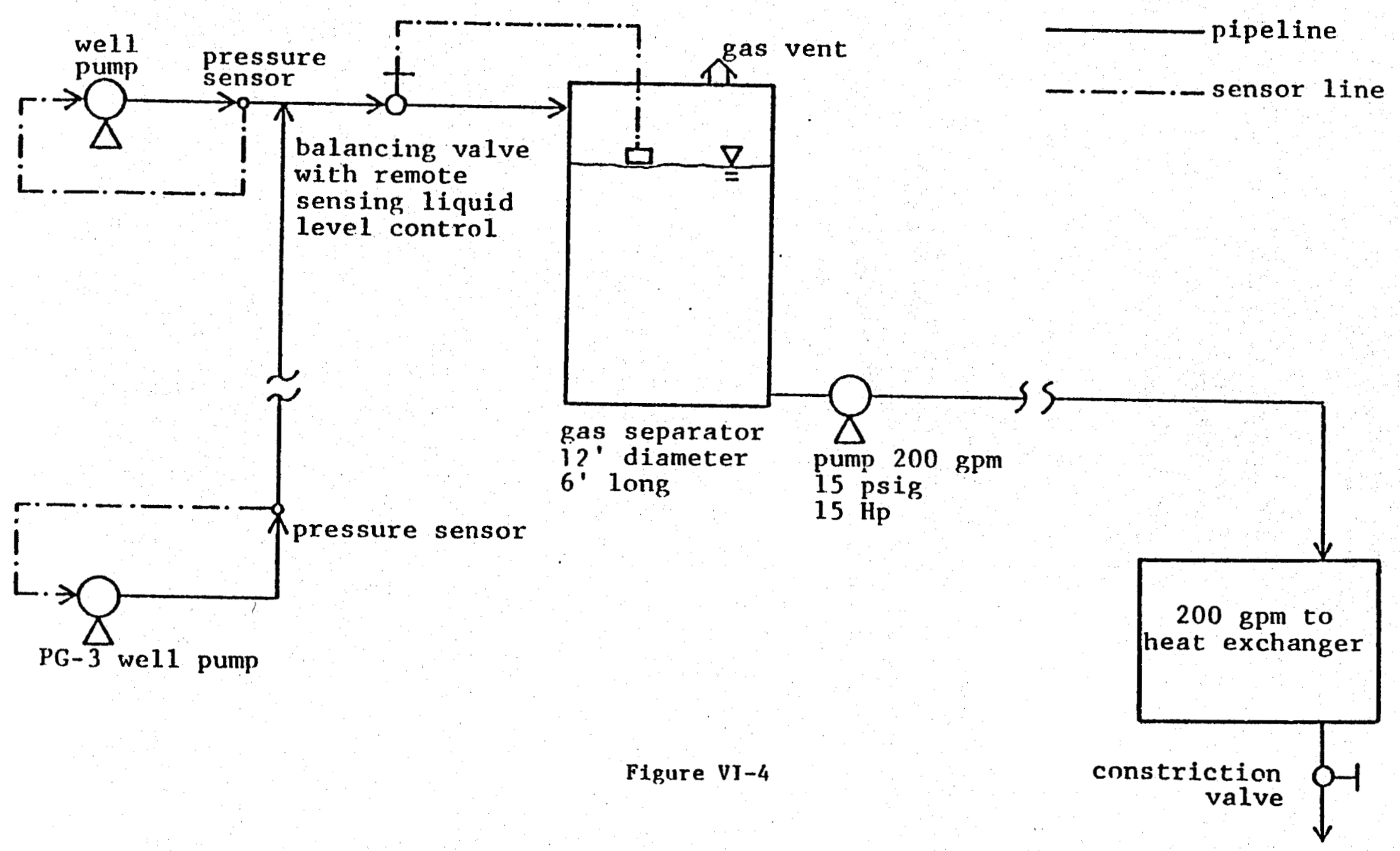




\section{Section VII}

\section{HOT WATER STORAGE TANK DESIGN}

\section{General}

From the analysis of peak and average flow rates in the 12 target buildings, a pattern has been established. With the exception of the outdoor pool, a cyclic consumption pattern exists. For a brief period, one to four hours in duration, the consumption is at a sharp peak. For the balance of the day, consumption is almost uniform except for two minor early and late evening peak demand periods. This instrumented data collection indicates the peak consumption rate is $320-400$ gallons per minute, and the 24-hour average consumption is 145-225 gallons per minute. If the outdoor swimming pool is excluded, the peak is 320 gallons per minute, with an average rate of 145 gallons per minute (Ratio of peak to average flow rate of approximately 2.2). These data are summarized as follows:

\begin{tabular}{lcc} 
& \multicolumn{2}{c}{ Table VII-1 } \\
& $\frac{\text { Summary of Hot Water Demand }}{}$ \\
\cline { 2 - 3 } & $\frac{\text { COMPOSITE }}{400}$ & $\frac{\text { COMPOSITE, LESS POOL }}{320}$ \\
Peak & 109 & 29 \\
Minimum & 225 & 145
\end{tabular}

\section{Design Data}

Tables VII-2 and VII-3 provide the hourly peak hot water consumption for each of the target buildings. Figure VII-1 is a plot of the data. These data are then summarized, with peak composite hourly flow rates with and without the outdoor pool, in Table VII-4. In turn, Table VII-5 
is a derived set of data which depicts calculated hourly average rate, and hourly consumption, for the overall composite peak flow rates. For summaries of individual building daily flow patterns see Figures VII-6 through VII-12. 
Table VII-2

Hourly Peak Hot Water Demand, by Building

TIME OF

\begin{tabular}{|c|c|c|c|c|c|c|}
\hline DAY & ALUMNI & WRC & REGENTS & PAN AM & GARCIA & RHODES \\
\hline 0000 & 7 & 26 & 4 & 0 & 12 & 8 \\
\hline 0100 & 4 & 6 & 0 & 0 & 10 & 2 \\
\hline 0200 & 2 & 6 & 0 & 0 & 6 & 2 \\
\hline 0300 & 2 & 4 & 0 & 0 & 4 & 1 \\
\hline 0400 & 2 & 4 & 0 & 0 & 4 & 1 \\
\hline 0500 & 35 & 10 & 0 & 0 & 4 & 3 \\
\hline 0600 & 45 & 35 & 4 & 0 & 30 & 12 \\
\hline 0700 & 55 & 45 & 22 & 10 & 60 & 15 \\
\hline 0800 & 75 & 70 & 40 & 29 & 60 & 18 \\
\hline 0900 & 50 & 40 & 32 & 24 & 45 & 13 \\
\hline 1000 & 35 & 32 & 30 & 12 & 40 & 11 \\
\hline 1100 & 34 & 30 & 28 & 10 & 40 & 10 \\
\hline 1200 & 33 & 36 & 24 & 8 & 30 & 12 \\
\hline 1300 & 34 & 40 & 22 & 8 & 28 & 13 \\
\hline 1400 & 26 & 30 & 16 & 12 & 22 & 10 \\
\hline 1500 & 36 & 20 & 14 & 12 & 20 & 7 \\
\hline 1600 & 28 & 36 & 14 & 10 & 20 & 12 \\
\hline 1700 & 22 & 40 & 12 & 8 & 20 & 13 \\
\hline 1800 & 26 & 30 & 8 & 3 & 20 & 10 \\
\hline 1900 & 34 & 36 & 12 & 2 & 20 & 12 \\
\hline 2000 & 26 & 34 & 12 & 8 & 18 & 11 \\
\hline 2100 & 22 & 30 & 20 & 7 & 15 & 10 \\
\hline 2200 & 20 & 40 & 18 & 7 & 18 & 13 \\
\hline 2300 & 20 & 30 & 16 & 1 & 20 & 10 \\
\hline
\end{tabular}


Table VII-3

Hourly Peak Hot Water Demand, by Building

\begin{tabular}{|c|c|c|c|c|c|}
\hline $\begin{array}{l}\text { TIME OF } \\
\text { DAY }\end{array}$ & $\begin{array}{l}\text { ACTIVITY } \\
\text { CENTER } \\
\end{array}$ & $\begin{array}{l}\text { FOOTBALL } \\
\text { STADIUM }\end{array}$ & NATATORIUM & $\begin{array}{c}\text { INDOOR } \\
\text { POOL } \\
\end{array}$ & $\begin{array}{l}\text { OUTDOOR } \\
\text { POOL } \\
\end{array}$ \\
\hline 0000 & 0 & 0 & 0 & 18 & 80 \\
\hline 0100 & 0 & 0 & 0 & 18 & 80 \\
\hline 0200 & 0 & 0 & 0 & 18 & 80 \\
\hline 0300 & 0 & 0 & 0 & 18 & 80 \\
\hline 0400 & 0 & 0 & 0 & 18 & 80 \\
\hline 0500 & 0 & 0 & 0 & 18 & 80 \\
\hline 0600 & 0 & 0 & 0 & 18 & 80 \\
\hline 0700 & 0 & 0 & 0 & 18 & 80 \\
\hline 0800 & 10 & 0 & 0 & 18 & 80 \\
\hline 0900 & 10 & 0 & 8 & 18 & 80 \\
\hline 1000 & 30. & 0 & 3 & 18 & 80 \\
\hline 1100 & 20 & 0 & 3 & 18 & 80 \\
\hline 1200 & 15 & 6 & 5 & 18 & 80 \\
\hline 1300 & 15 & 20 & 10 & 18 & 80 \\
\hline 1400 & 15 & 10 & 8 & 18 & 80 \\
\hline 1500 & 10 & 14 & 5 & 18 & 80 \\
\hline 1600 & 7 & 25 & 3 & 18 & 80 \\
\hline 1700 & 6 & 45 & 3 & 18 & 80 \\
\hline 1800 & 4 & 7 & 3 & 18 & 80 \\
\hline 1900 & 3 & 7 & 3 & 18 & 80 \\
\hline 2000 & 3 & 7 & 0 & 18 & 80 \\
\hline 2100 & 1 & 7 & 0 & 18 & 80 \\
\hline 2200 & 0 & 22 & 0 & 18 & 80 \\
\hline 2300 & 0 & 7 & 0 & 18 & 80 \\
\hline
\end{tabular}


Table VII-4

Composite Hourly Water Demand

TIME OF

DAY

0000

0100

0200

0300

0400

0500

0600

0700

0800

0900

1000

1100

1200

1300

1400

1500

1600

1700

1800

1900

2000

2100

2200

2300

\section{COMPOSITE}

75

40

34

29

29

70

144

225

320

235

211

193

187

208

167

156

173

187

129

147

137

130

156

122
COMPOSITE INCLUDING OUTDOOR POOL

155

120

114

109

109

150

224

305

400

315

291

273

267

288

247

236

253

267

209

227

217

210

236

202 
Table VII-5

Composite Average Hourly Hot Water Consumption

\begin{tabular}{|c|c|c|c|}
\hline $\begin{array}{l}\text { TIME OF } \\
\text { DAY }\end{array}$ & $\begin{array}{l}\text { OUTFLOW HOURLY } \\
\text { AVERAGE (GPM) }\end{array}$ & $\begin{array}{l}\text { NET INFLOW } \\
\text { (GPM) }\end{array}$ & $\begin{array}{l}\text { NET HOURIY } \\
\text { CONSUMPTION (GALS) }\end{array}$ \\
\hline $2400-0100$ & 140 & +90 & +5400 \\
\hline $0100-0200$ & 120 & +110 & +6600 \\
\hline $0200-0300$ & 115 & +115 & +6900 \\
\hline $0300-0400$ & 110 & +120 & +7200 \\
\hline $0400-0500$ & 130 & +100 & +6000 \\
\hline $0500-0600$ & 190 & +40 & +2400 \\
\hline $0600-0700$ & 270 & -40 & -2400 \\
\hline $0700-0800$ & 360 & -130 & -7800 \\
\hline $0800-0900$ & 365 & -135 & -8100 \\
\hline $0900-1000$ & 300 & -70 & -4200 \\
\hline $1000-1100$ & 285 & -65 & -3300 \\
\hline $1100-1200$ & 270 & -40 & -2400 \\
\hline $1200-1300$ & 280 & -50 & -3000 \\
\hline $1300-1400$ & 270 & -40 & -2400 \\
\hline $1400-1500$ & 260 & -30 & -1800 \\
\hline $1500-1600$ & 260 & -30 & -1800 \\
\hline $1600-1700$ & 260 & -30 & -1800 \\
\hline $1700-1800$ & 240 & -10 & -600 \\
\hline $1800-1900$ & 220 & +10 & +600 \\
\hline $1900-2000$ & 220 & +10 & +600 \\
\hline $2000-2100$ & 215 & +15 & +900 \\
\hline $2100-2200$ & 230 & -- & $\cdots$ \\
\hline $2200-2300$ & 220 & +10 & +600 \\
\hline \multirow[t]{3}{*}{$2300-2400$} & 180 & +50 & +3000 \\
\hline & & & $S+40,500$ \\
\hline & & & $s-39,600$ \\
\hline
\end{tabular}

Based on $200 \mathrm{gpm}$ constant flow from H/E, plus $30 \mathrm{gpm}$ from auxiliary emergency heater. 


\section{COMPOSITE HOT WATER DEMAND}

(gpm)

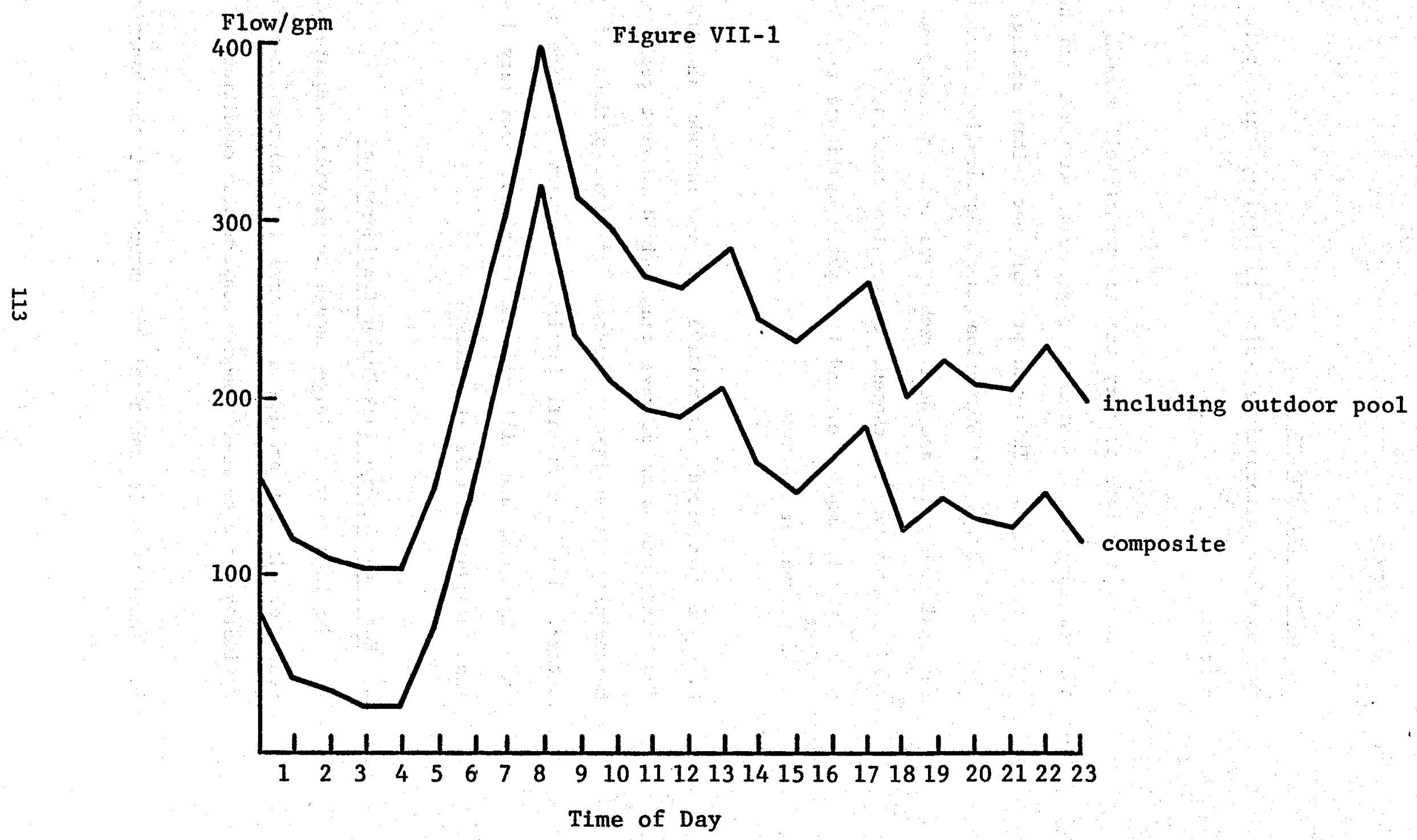




\section{Alternative Designs}

Two possible alternatives exist to satisfy this cyclic consumption pattern.

a. It is possible to vary the geothermal well pumping rate and flow through the entire system to meet peak, minimum, and hence average consumption needs. This concept would necessitate sizing and operating the well pumps, transmission and distribution system pipelines, recirculation pumps and heat exchangers to meet peak flow demands. If this alternative is chosen, the system construction cost would be prohibitively expensive, and the system would use peak capacity only 10-15 percent of the time.

b. The preferred alternative is to include in the system an insulated hot water storage tank, sized to meet peak demands, while maintaining an emergency reserve for short periods of minor system outage. This design will facilitate minimum effective size for pumps and pipelines, and will provide additional ancillary benefits. Our final design uses this alternative.

\section{Hot Water Storage Tank Design Considerations}

a. The tank must be large enough to provide adequate water to meet peak demands and provide a reserve for short-duration outages, yet optimally-sized to meet economic construction conditions.

b. Insulation is essential to assure that the beneficial heat is retained. 
c. Provision must be made for constant replenishment flow at some rate lower than the peak demand rate.

d. To balance hot and cold water service to the target buildings, the tank and distribution system must be capable of pressurization to 80 psig, or an alternative in-line pump used at the outlet of the storage tank to balance line pressures with the domestic cold water system.

e. To satisfy engineering requirements for sufficient head over the intake to the in-line pump, the pump suction line from the tank must have design provisions to assure continuous availability of at least four feet of static head above the pump inlet. In addition, the water in the tank will tend to stratify by temperature, with cooler water in the lowest portion. The design must make practical provision to guard against supply only from this cooler portion.

f. For back-up in periods of extended outages, provision must be made for emergency heat supply to heat cold water. Those outages are defined as a major failure in the wells or well pump, pipeline, or heat exchanger which require repair time more than a few hours in duration. Implicit in this design feature is a need to assure continuity of hot water supply for periods up to four days in duration. (Four days is assumed to be a realistic period of time in which the central boiler 
could be heated from a cold start to provide conventional service to the target buildings, if in future operations the central steam plant is shut down during the non-heating season.)

g. The storage tank must be sited contiguous to the existing utility tunnel system, at a location that currently has natural gas service, or to which natural gas service could be supplied at minimum cost.

\section{Hot Water Storage Tank Design}

From previous data, the peak demand is $400 \mathrm{gpm}$, average demand is $225 \mathrm{gpm}$, and minimum demand is $39 \mathrm{gpm}$.

To meet peak and average demand, the tank will be replenished by an in flow of $225 \mathrm{gpm}$, and this inflow will provide capacity for peak demands of $400 \mathrm{gpm}$. By setting the flow from the well field through the heat exchanger complex at $200 \mathrm{gpm}$, a need would exist for a make-up flow of 25-30 $\mathrm{gpm}$ from an auxiliary source. The well-field flow could be set at 225-230 $\mathrm{gpm}$, thus eliminating the need for the auxiliary source. However, the auxiliary flow is designed to keep one of the standby emergency boilers at constant temperature for quick reaction during night time or weekend emergency situations.

Given a constant inflow of hot water and a variable demand, the tank must be large enough to provide a reserve for limited duration emergencies, and to maintain a minimum static water level above the discharge pump. A tank capacity of 60,000 gallons will satisfy these conditions as defined in the following paragraphs. 
In reviewing the consequences of this design, the tank will be depleted during the time period from $6: 00$ am to $6: 00 \mathrm{pm}$ daily, and replenished during the period from $6: 00 \mathrm{pm}$ to $6: 00 \mathrm{am}$. With a starting capacity of 60,000 gallons, the lowest water level will be approximately 20,000 gallons. At this volume, the liquid level would be at least five feet of water over tank bottom, and four feet over pump inlet section; therefore this design objective is satisfied.

Should catastrophic failure occur in the supply system, the worst case is failure when the tank is least full. Under emergency conditions, supply to the outdoor pool will be terminated, so demand will be reduced. In the time-period from $6: 00 \mathrm{pm}$ to midnight, the average flow excluding the pool is $139 \mathrm{gpm}$. Thus, emergency conditions would provide approximately three hours of supply.

If failure occurs just prior to start of peak demand, the tank will provide a 15-hour reserve of hot water. Thus, the storage tank with a 60,000 gallon capacity will satisfy the design objective. Moreover, under any conditions, the tank will retain sufficient volume of hot water to permit a $2-3$ hour technician delay in completing minor repairs anywhere in the system. The automatic controls on the auxiliary heater are designed to provide quick reaction to a stoppage of in flow hot water, and the built-in reserve will allow time for a technician check of the system after automatic controls have been engaged.

A major design problem is the task of balancing the line pressure between the domestic cold water supply and the geothermal-supplied hot water. For the current system, this problem does not exist because the 
domestic hot water is supplied by a make-up cold water stream into the building heat exchanger, and water line pressures are automatically stabilized. However, for the new system, the hot and cold water systems are independent until the final building end-use consumption. Hence, a pressure balancing system is needed. A continuous pressure recorder was installed on the main domestic cold water line. Analysis of recorded data indicates that line pressure fluctuates in the range of 45 to 65 psig during operation of the main supply well. Our design makes use of a constant speed pump, designed to deliver up to $500 \mathrm{gpm}$ at 80 psig discharge pressure. This pump will exit into a balancing valve, and the valve will be controlled by a pressure sensor off the main domestic cold water line, with a reference pressure sensor in the new hot water line. The balancing valve will respond to pressure differential, and provide a variable flow of domestic hot water balanced to the domestic cold water system. Unused flow will be diverted back into the bottom of the storage tank. This recycling feature has the added advantage of causing a mixing action in the storage tank to overcome the tendency for the water in the tank to temperature stratify. To further control stratification, this recycle stream will feed into the bottom of the storage tank.

Also, to aid in overcoming the temperature stratification problem and to assure a maximum static head is maintained over the pump suction, the pump inlet will be a floating head type. This pump suction device is designed to provide draw-down of the presumably hotter water strata in the upper part of the tank. 
Auxiliary heaters, natural-gas fired, are required as emergency back-up. In concept, those heaters are sized to meet the average demand exclusive of the outdoor pool. As previously defined, a heater will be maintained in a ready condition constantly by using a small 25-30 gpm constant flow. For economy of scale, the design provides for two boilers, installed in parallel. Each boiler would have the capacity to handle $100 \mathrm{gpm}$ water, and a $60^{\circ} \mathrm{F}$ temperature rise at a load rating of 3.7 million BTU's per hour. As designed, the boilers would provide a total capacity of 7.5 million BTU's per hour, and would be capable of heating $200 \mathrm{gpm}$ of domestic cold water from $65^{\circ} \mathrm{F}$ to $125^{\circ} \mathrm{F}$, which is the desired tank temperature. The maximum heat load under emergency conditions with the outdoor pool service terminated is at average flow of $145 \mathrm{gpm}$. Under this condition,

$$
\begin{aligned}
\text { Heat Load } & =145 \mathrm{gpm} \times 60^{\circ} \mathrm{F} \times 8.34 \times 60 \mathrm{~min} / \mathrm{hr} 0.8 \mathrm{eff} \\
& =5.4 \mathrm{million} \mathrm{BTU} / \mathrm{hour}
\end{aligned}
$$

If the outdoor pool is included, average flow is $200 \mathrm{gpm}$, and

$$
\begin{aligned}
\text { Heat Load } & =200 \times 60 \times 8.34 \times 60 \cdot 0.8 \\
& =7.5 \text { million BTU/hour }
\end{aligned}
$$

Inflow for emergency operations would be governed by a liquid level sensor in the storage tank, designed to initiate flow through an auxiliary heater when the water level in the tank dropped to a pre-set distance above tank bottom. Output temperature from the boiler will be governed by temperature sensors in the output side, which will control flow to assure temperature minimums are met.

Because the tank is maintained at atmospheric pressure, it will tend to breath. During the 18-hour period of maximum demand flow (net draw down period) the tank will draw in ambient air. This air will be preheated 
by a ducting system routed past the natural gas heater. When the tank is refilling during the period 6:00 pm to 6:00 am daily, the air will exhaust through a vent. Under normal conditions, the maximum air flow during exhale or intake will not exceed five cubic feet per minute (CFM). Average airflow will be 2 to $4 \mathrm{cfm}$. This small volume of air can be easily handled in the complex. Heat loss during the venting cycle is expected to be minor.

Natural gas service for these boilers is in the tunnel complex, and can be extended to the hot water storage tank at minimum cost. Schematic representations of the hot water storage tank, the floating head pump suction, and the auxiliary heater are depicted in Figures VII-2, VII-3, and VII-4. The individual building hot water demand curves are plotted in Figures VII-5 through VII-11. 


\section{DETAILED SCHEMATIC HOT WATER STORAGE TANK} WITH VARIABLE LEVEL WATER INTAKE

Figure VII-2

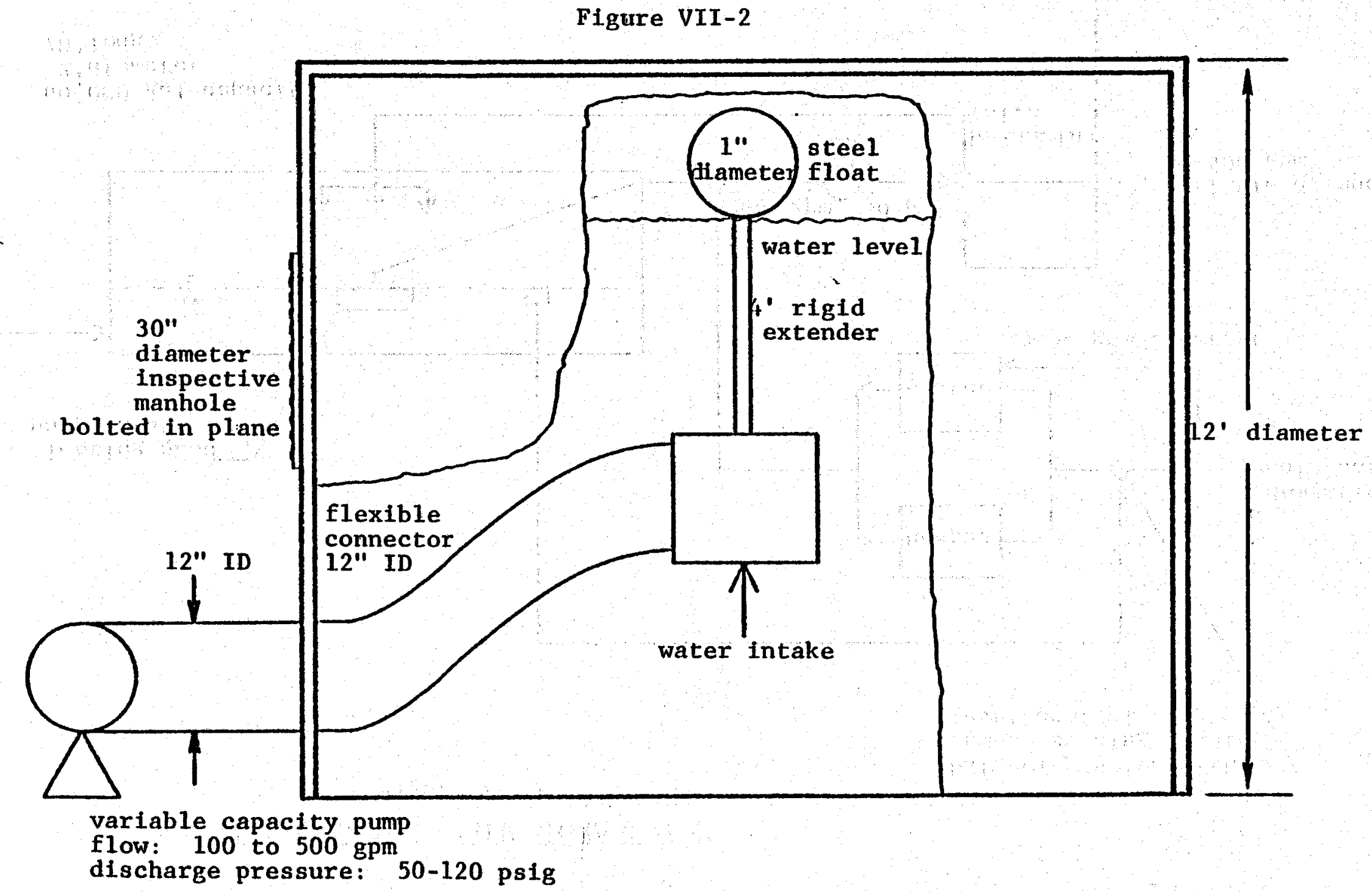




\section{DETAILS OF HOT WATER STORAGE TANK}

Figure VII-3

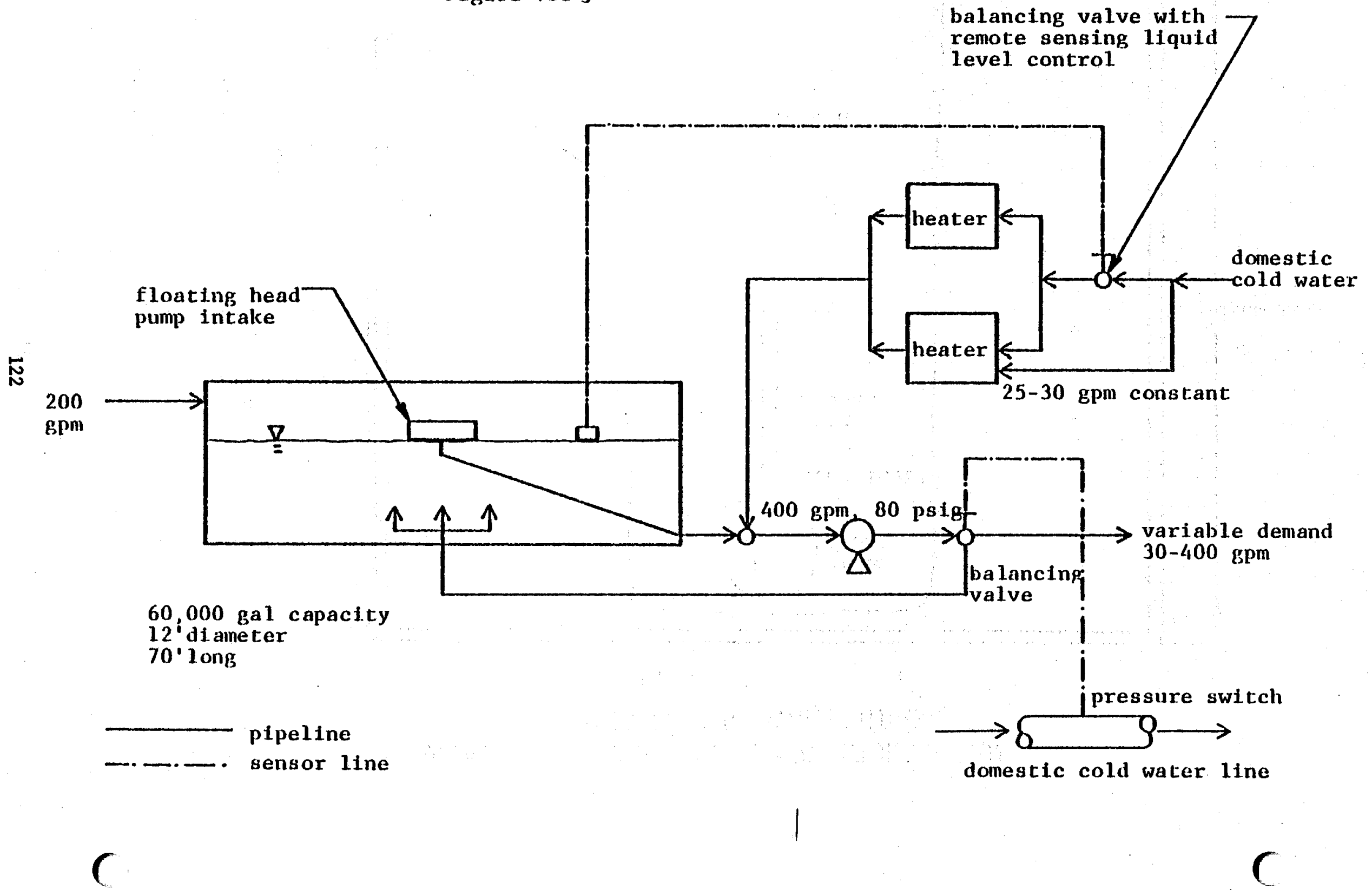




\section{DETAILS OF AUXILIARY HEATER \\ Figure VII-4}

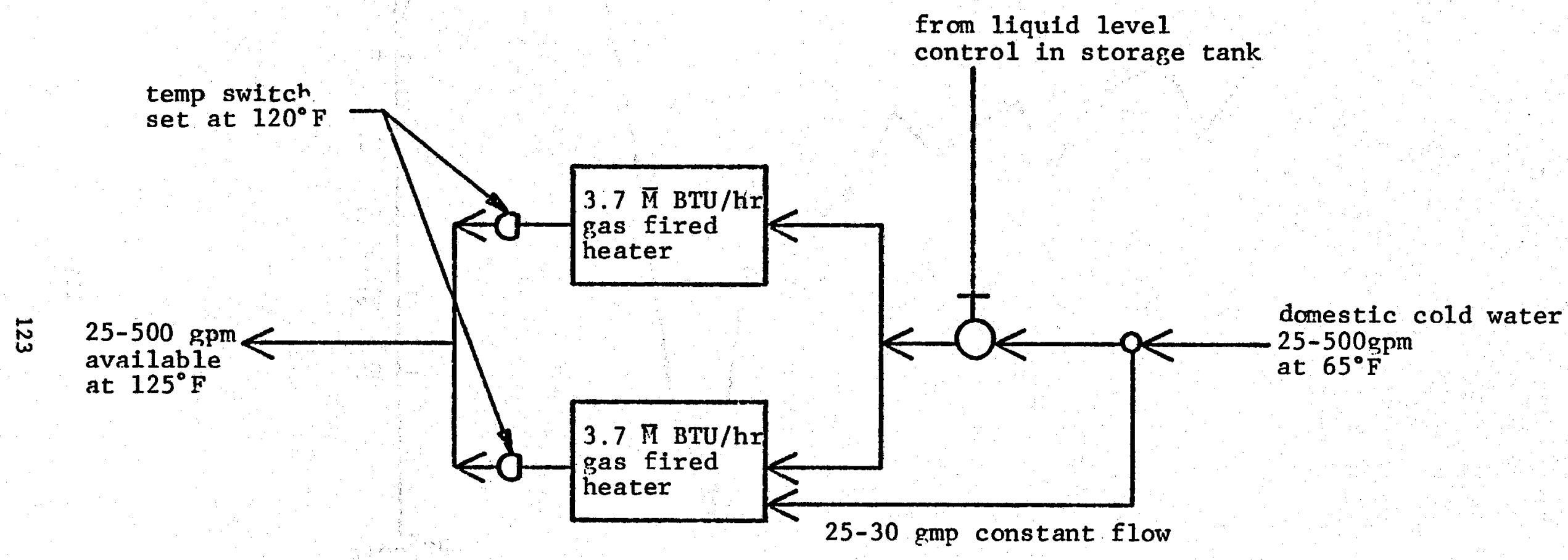


ALUMNI AVERAGE FLOW

ADJUSTED TO $125^{\circ} \mathrm{F}$

Figure VII-5

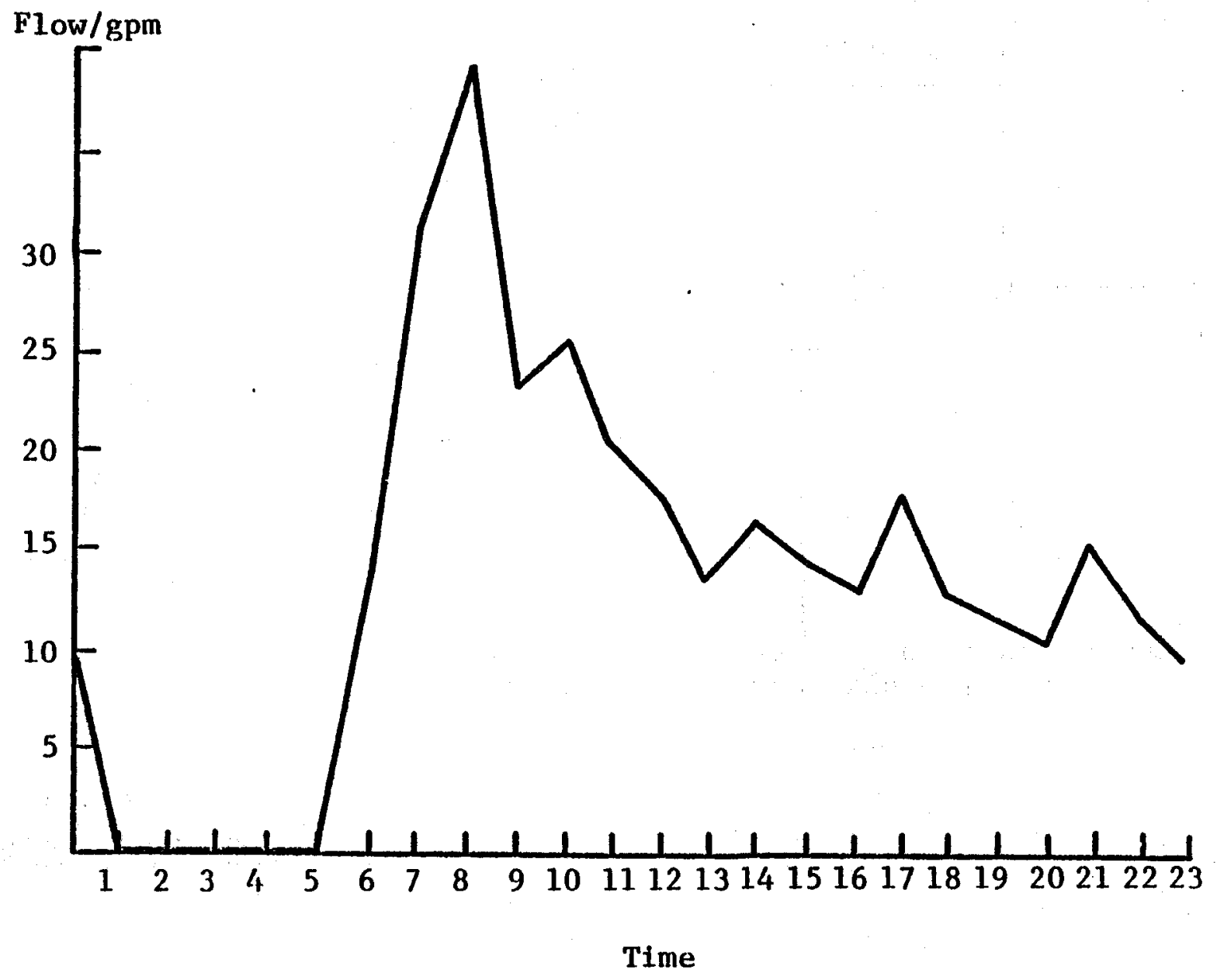




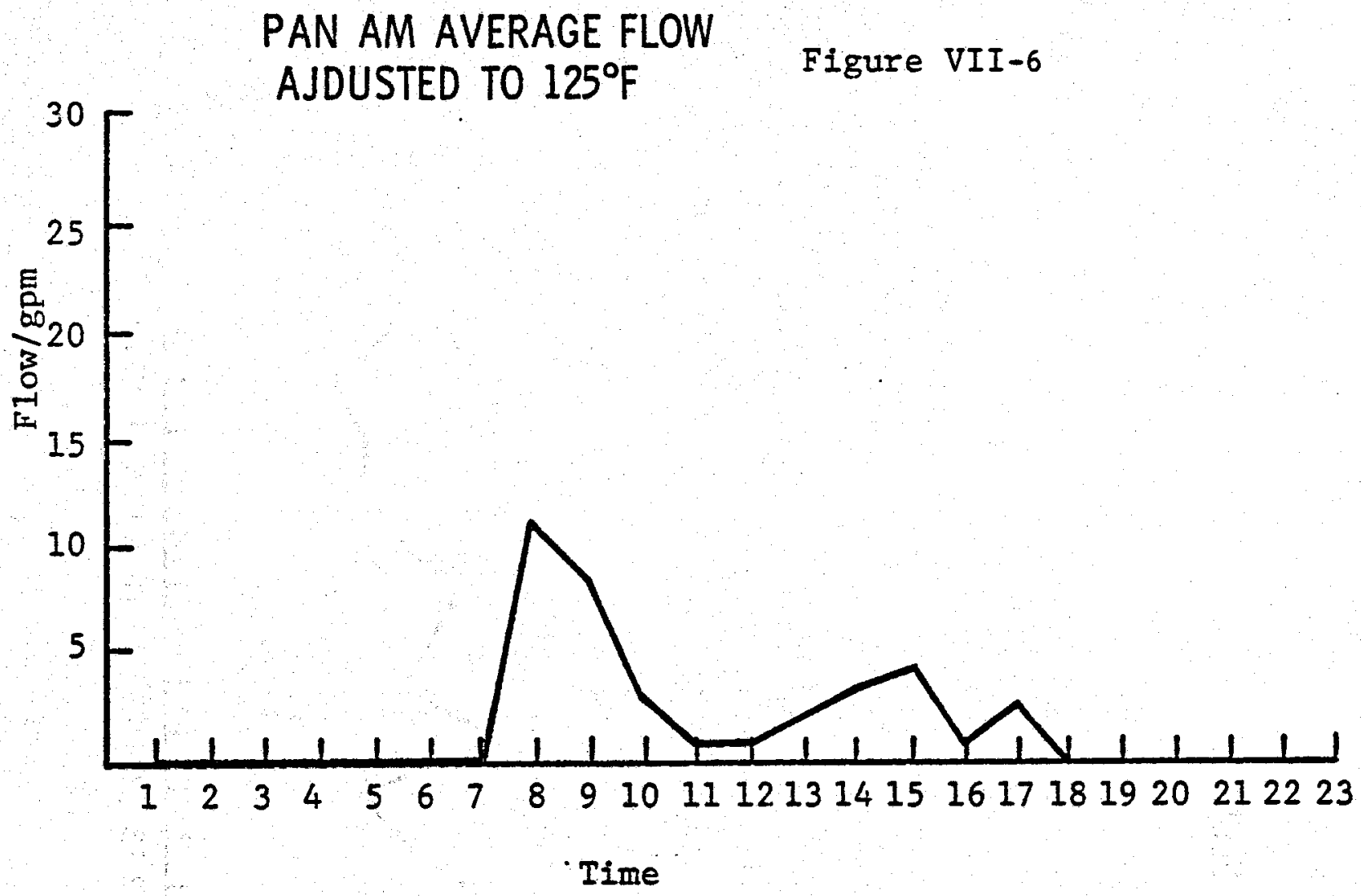

WRC AVERAGE FLOW

ADJUSTED TO $125^{\circ} \mathrm{F}$ - Figure VII-7

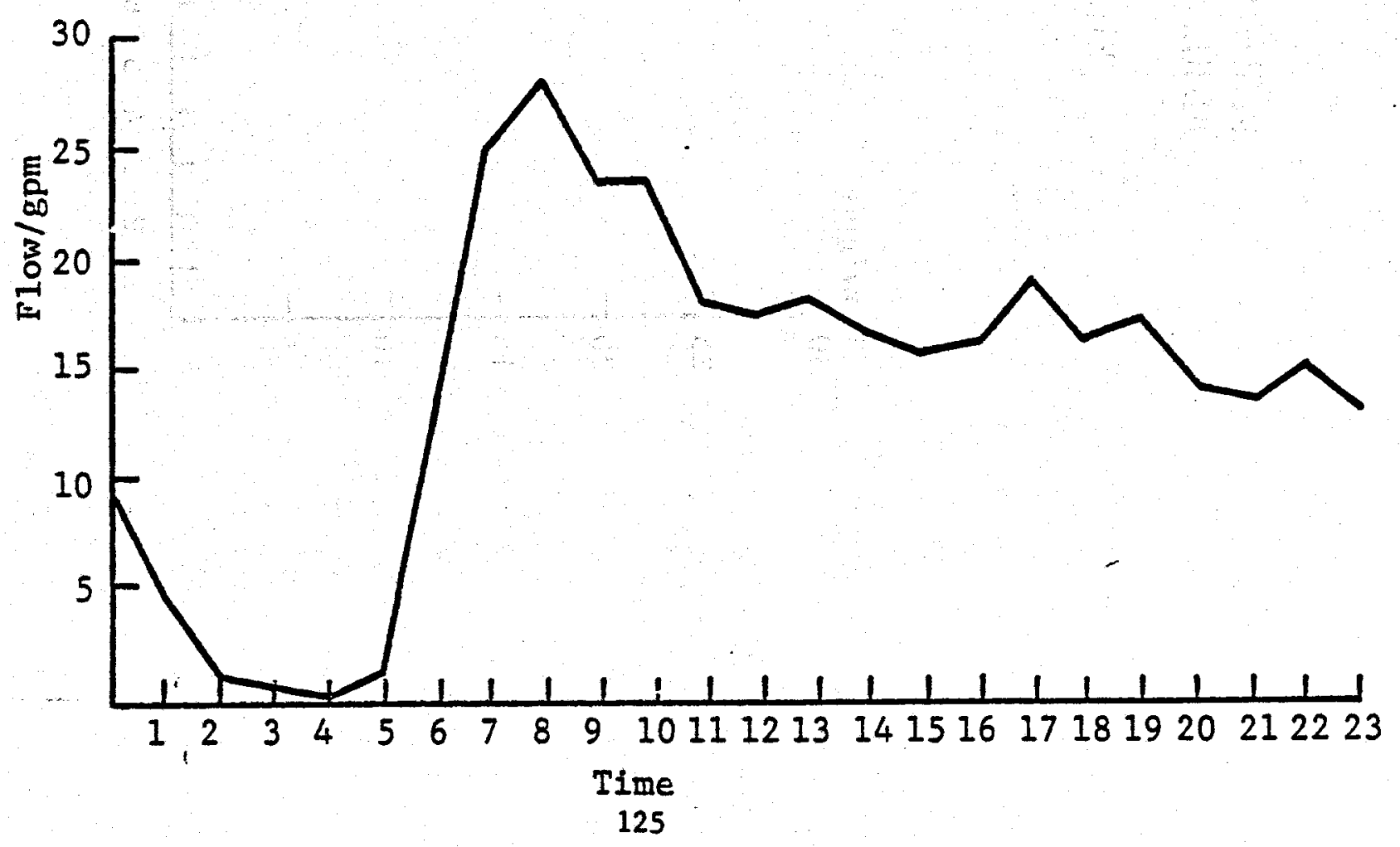


REGENTS ROW AVERAGE FLOW

ADJUSTED TO $125^{\circ} \mathrm{F}$

Figure VII-8

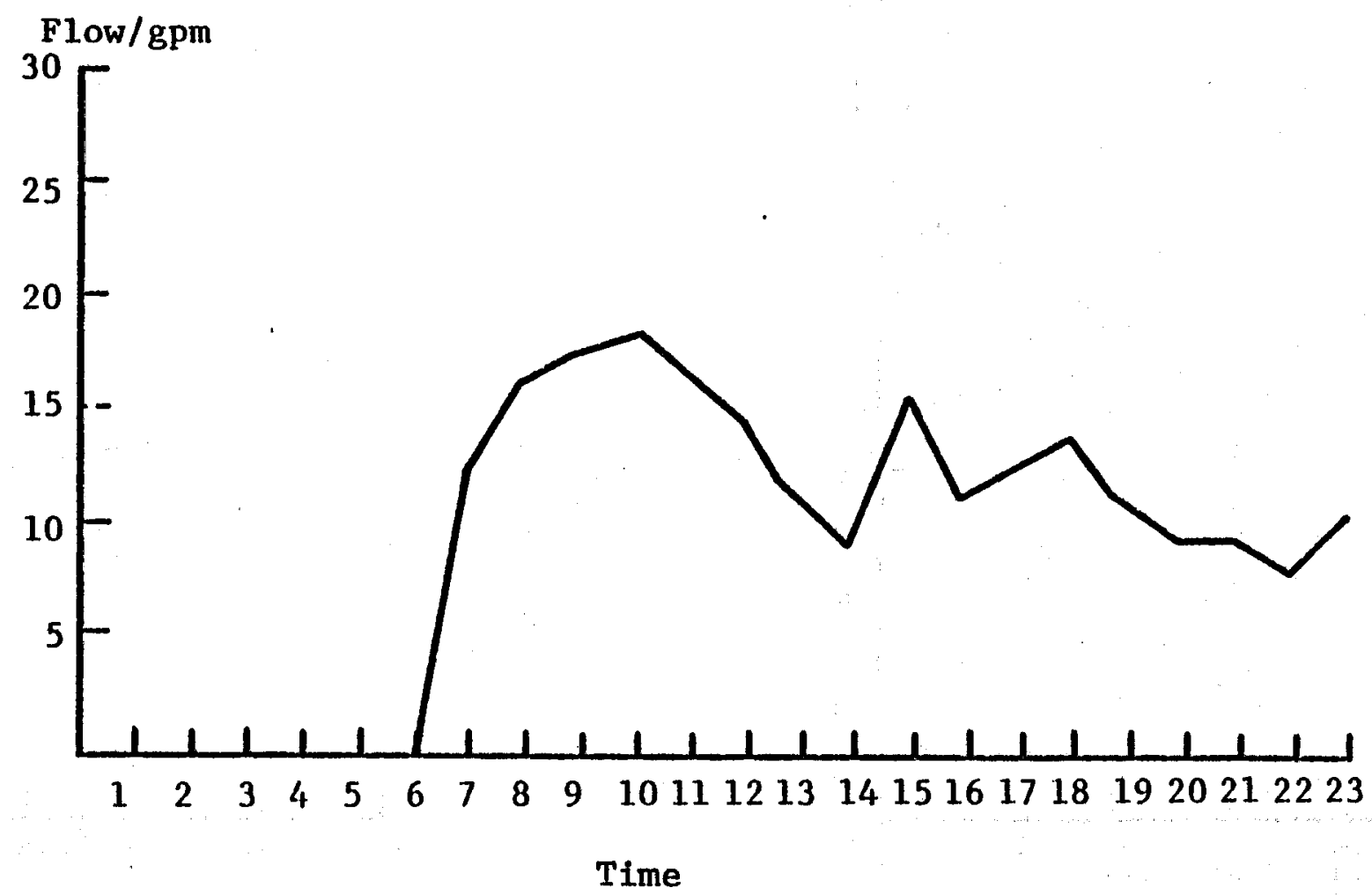


GARCIA HALL AVERAGE FLOW

ADJUSTED TO $125^{\circ} \mathrm{F}$

Figure VII-9

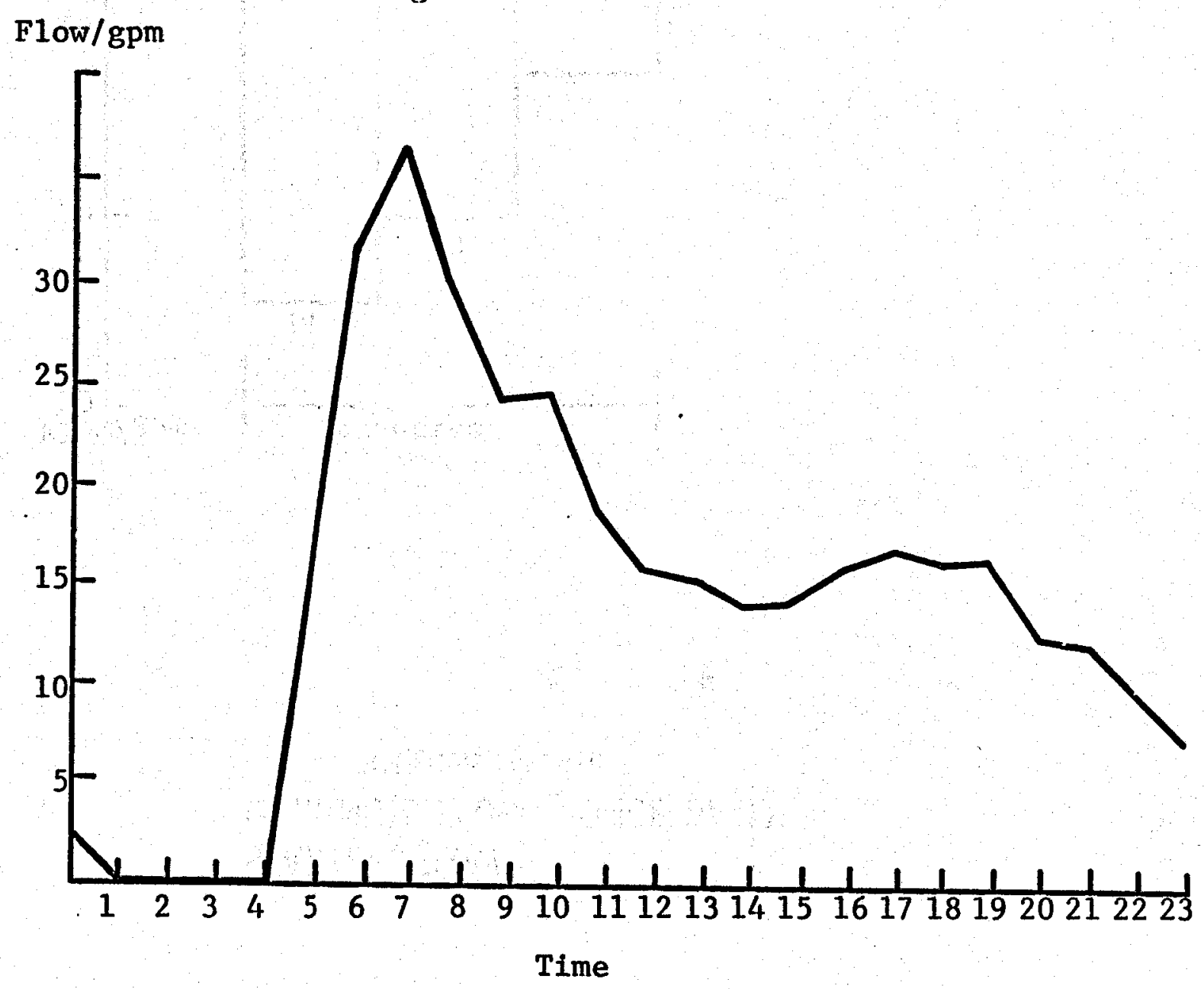


STADIUM FLOW

15 MINUTE FLOW - ONCE DAILY

Figure VII-10

స్ల

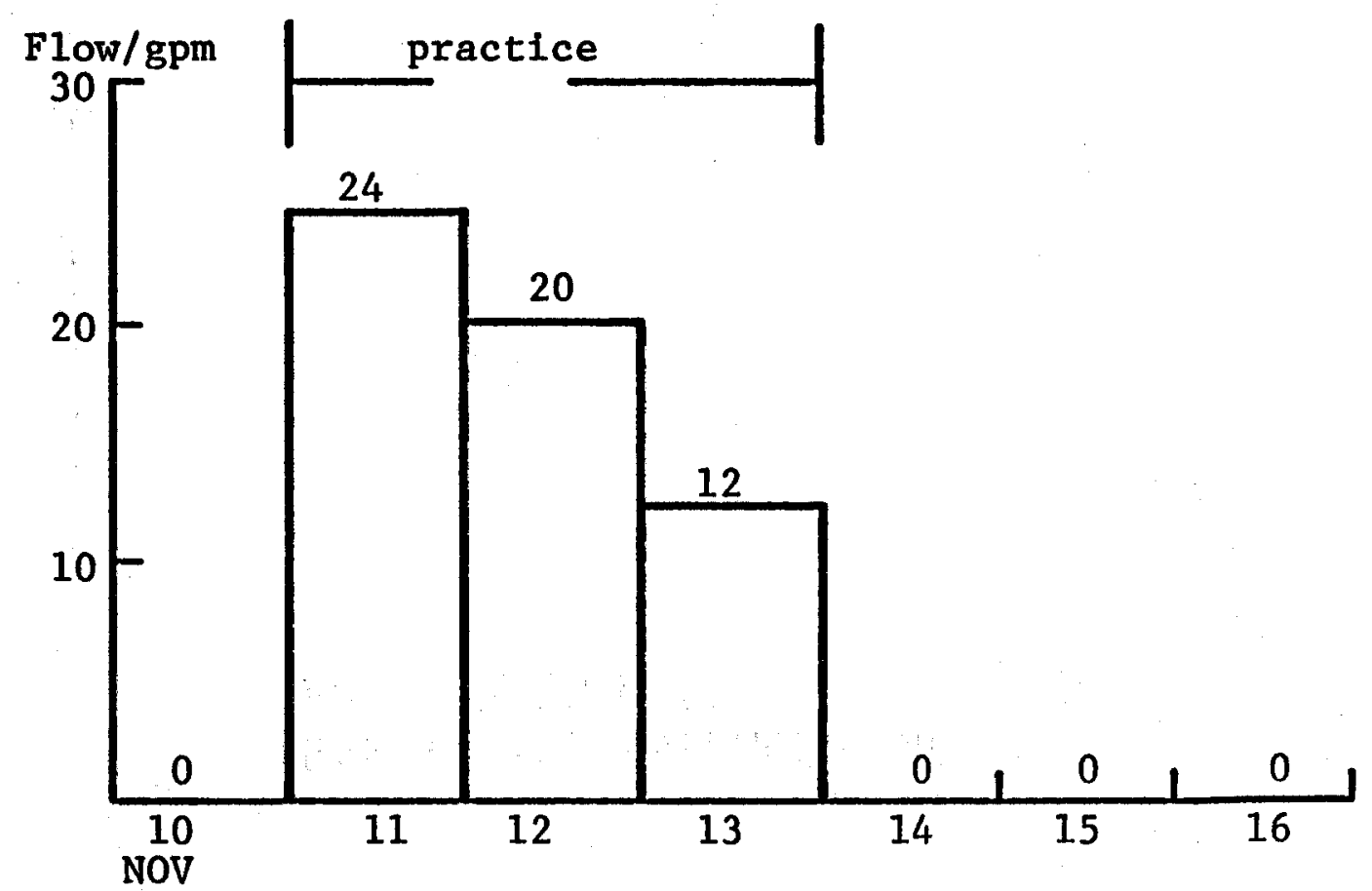




\section{STADIUM FLOW}

15 MINUTE PEAKS - ONCE DAILY

Figure VII-11

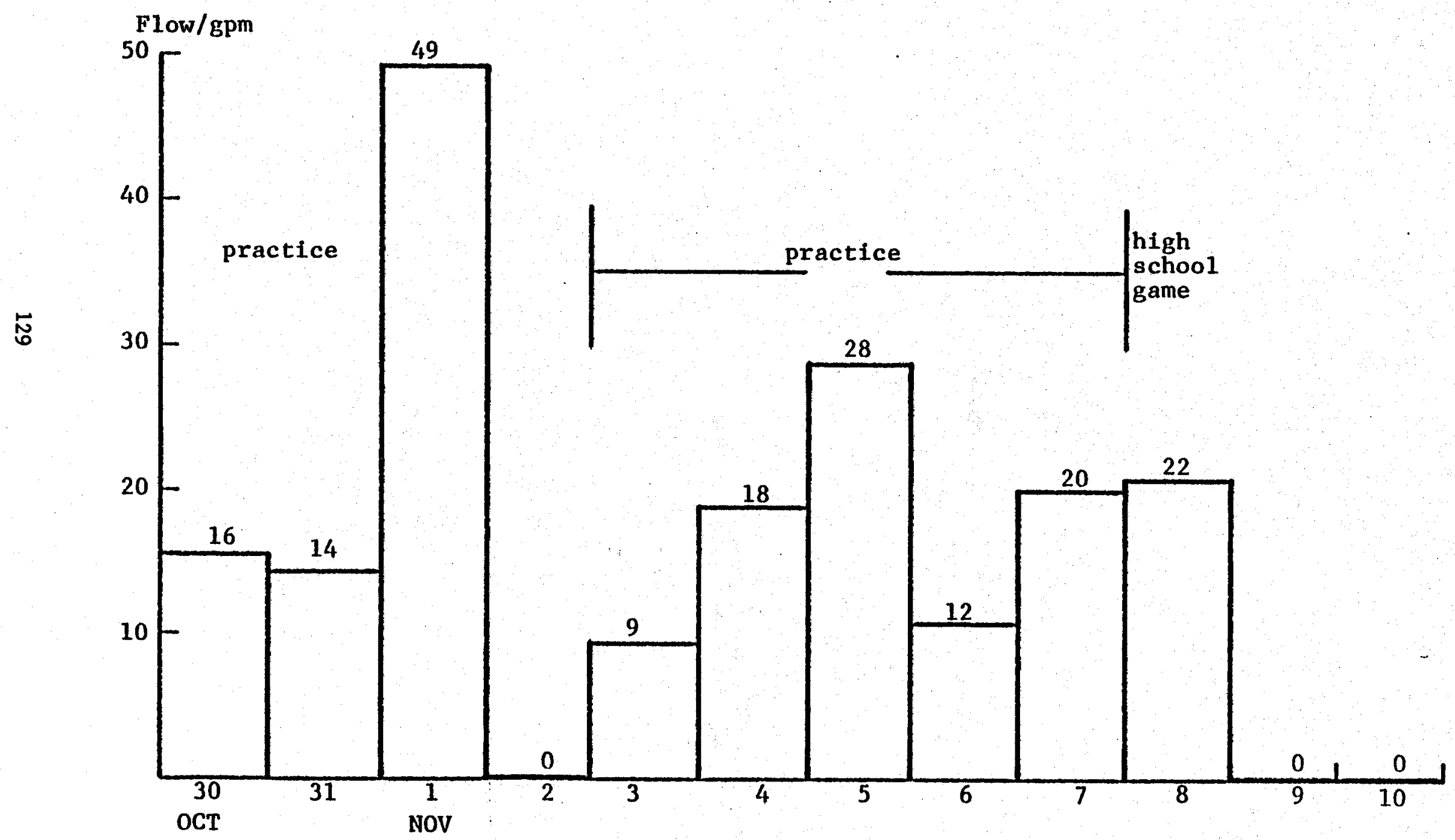


$\checkmark$ 


\section{HEAT EXCHANGER DESIGN}

\section{Alternate Concepts}

In order to achieve the maximum beneficial use of the heat available from the geothermal water, an efficient system of heat exchange between the cool potable water and the geothermally-heated water must be implemented. The design team considered piping the geothermal water directly to the user buildings, in a closed-loop recirculation system.

However, extending the geothermal direct loop to the campus buildings would necessitate a very costly return loop to the east to connect with the disposal systems, which must be on the east side of Intrastate Highway I-25. In addition, due to the chemical composition of the geothermal fluids, it would be impractical to transport the water directly to the heat exchangers in the user buildings to perform the temperature exchange between the cooler potable water and the hot geothermal water. The heat exchangers located in the individual buildings have not been designed to handle the potentially corrosive nature of the geothermal water. Therefore, it is imperative to implement a system of heat exchangers which will be capable of withstanding the corrosive geothermal waters and also provide efficient temperature exchange.

\section{Preferred Design}

To achieve the heat transfer needed, and to avoid the cost of a return loop to dispose of the spent geothermal water for direct building use, 
design plans place the heat exchanger in the vicinity of the four million gallon domestic water tank located on the East side of I-25, adjacent to the NMSU Golf Course.

The geothermal water will be piped directly to the heat exchanger site. There, potable water from the domestic water supply tank will be heated by the geothermal water. The spent geothermal water will then be transported to a disposal site. The potable hot water will be piped directly to the user buildings.

\section{Heat Exchanger Selection}

Choosing the proper heat exchanger to yield the maximum heat exchange and also be capable of withstanding the corrosive geothermal water requires careful study of model types and construction. Heat exchanger suppliers were contacted, and their cost and performance data resulted in a design decision to use plate-type exchangers. These are simple, reliable, and easily maintained units. It is true that a conventional shell-in-tube exchanger also is reliable and easy to maintain, particularly if the geothermal water is contained in the tube side. However, the plate-type exchanger is capable of a closer approach temperature for a given cost than is the shell and tube exchanger. Because getting the highest possible domestic water temperature for a given cost is the primary consideration, a decision was made to include only plate-type exchangers.

Another project consideration is the use of a heat exchanger at the MMSU Outdoor Pool. In order to maintain the pool water at a constant temperature, a heat exchange between the pool water and potable hot 
water must take place. The heat source for the pool is domestic hot water. In concept, the exchangers will use circulating pool water from the filter system, which will then be warmed by the domestic hot water. Consideration was given to warming the pool by direct inflow of warm water. Not only would this be insufficient, but more serious problems would arise.

For every gallon of warm water piped into the pool, an equal volume of pool water would require disposal. Since the outdoor pool heating load would require $80-100$ 8pm of warm water, then this amount of heavily chlorinated pool water would require disposal. Because of the condition of this swimming pool water, it would have to be flushed through the storm drains. Moreover, with such a continual mixing and diluting, the cost of chemicals to maintain health standards would be excessive. For those reasons, the design decision was to use a small, plate-type exchanger for the outdoor pool. Selection of materials is critical, since the outdoor pool water is potentially more corrosive than the geothermal water. Table VIII-1 is an analysis of the swimming pool water.

Table VIII-1

Analysis of Outdoor Pool Water

Swimming Pool Water Analysis

\begin{tabular}{|c|c|}
\hline $\begin{array}{l}\text { Date of Sampling } \\
\text { Date of Analysis }\end{array}$ & $\begin{array}{l}4 / 11 / 81 \\
4 / 15 / 81\end{array}$ \\
\hline $\begin{array}{l}\mathrm{pH} \\
\text { Conductivity } \\
\mathrm{Cl}_{+} \\
\mathrm{Na}_{+}^{+} \\
\mathrm{K}^{+} \\
\mathrm{Fe}_{++} \\
\mathrm{Ca}_{++}^{++} \\
\mathrm{Mg}^{+} \\
\text {TDS }\end{array}$ & $\begin{array}{l}6.64 \\
3.61 \mathrm{mmhos}^{\prime} / \mathrm{cm} \\
966 \mathrm{ppm}^{*} \\
480 \mathrm{ppm}^{*} \\
14 \mathrm{ppm}^{*} \\
\mathrm{nil}(<0.5 \mathrm{ppm})^{*} \\
212 \mathrm{ppm}^{*} \\
12.1 \mathrm{ppm}^{*} \\
2085 \mathrm{ppm}^{*}\end{array}$ \\
\hline
\end{tabular}




\section{Heat Exchanger Size and Cost}

Price quotations were obtained from possible suppliers, and the least cost and best performance quoted was from the Trantor Corporation. Summary description and technical specifications are attached. See Table VIII-1 and Figures VIII-1 through VIII-4.

\section{Heat Exchanger Building}

Although a single exchanger, capable of handling $200 \mathrm{gpm}$ of hot water, is needed, the design team felt that flexibility should be created for space for a second exchanger for possible future system expansion. Moreover, in-line circulation pumps are required on the cold water inlet side, and other controls and instrumentation are necessary. To meet these spatial requirements, a 300 square feet building is necessary. A cost estimate is included in Section XI, Cost and Benefits Analysis. Figure VIII-5 is a schematic representation of the heat exchanger complex. 
Table VIII-2

Heat Exchangers

Swimming Pool

\begin{tabular}{|c|c|c|c|c|c|c|}
\hline Mfg. & Model No. & Hot GPM & Cold GPM & Approach & Cost & Materis \\
\hline $\begin{array}{l}\text { Tranter } \\
\text { Tranter } \\
\text { Tranter } \\
\text { Tranter } \\
\text { Tranter } \\
\text { Tranter } \\
\text { Tranter }\end{array}$ & $\begin{array}{l}S-3-H J-18 \\
S-3-J H-29 \\
S-3-H P-34 \\
U X-216-H P-51 \\
U X-216-H P-62 \\
S-3-H J-9 \\
S-3-H J-9\end{array}$ & $\begin{array}{r}200 \\
200 \\
200 \\
200 \\
200 \\
75 \\
75\end{array}$ & $\begin{array}{l}300 \\
300 \\
300 \\
300 \\
300 \\
110 \\
110\end{array}$ & $\begin{array}{l}20^{\circ} \\
20^{\circ} \\
20^{\circ} \\
20^{\circ} \\
20^{\circ} \\
20^{\circ} \\
20^{\circ}\end{array}$ & $\begin{array}{l}2,808.00 \\
3,486.00 \\
3,895.00 \\
4,456.00 \\
4,994.00 \\
2,753.00 \\
4,431.00\end{array}$ & $\begin{array}{l}304 \text { S/S } \\
304 \mathrm{~S} / \mathrm{S} \\
304 \mathrm{~S} / \mathrm{S} \\
304 \mathrm{~S} / \mathrm{S} \\
304 \mathrm{~S} / \mathrm{S} \\
304 \mathrm{~S} / \mathrm{S} \\
\text { Titanium }\end{array}$ \\
\hline \multicolumn{7}{|c|}{ Primary (Titanium) } \\
\hline Mfg. & Model No. & Hot GP & Cold GPM & Approach & Cost & Mate \\
\hline $\begin{array}{l}\text { Tranter } \\
\text { Tranter } \\
\text { Tranter } \\
\text { Tranter } \\
\text { Tranter } \\
\text { Tranter }\end{array}$ & $\begin{array}{l}\mathrm{UX}-216-\mathrm{HP}-91 \\
\mathrm{UX}-216-\mathrm{HP}-179 \\
\mathrm{UX}-216-\mathrm{HP}-216 \\
\mathrm{UX}-416-\mathrm{HP}-250 \\
\mathrm{UX}-216-\mathrm{HP}-267 \\
\mathrm{UX}-416-\mathrm{HP}-376\end{array}$ & $\begin{array}{l}200 \\
400 \\
200 \\
400 \\
600 \\
600\end{array}$ & $\begin{array}{l}200 \\
400 \\
200 \\
400 \\
600 \\
600\end{array}$ & $\begin{array}{l}20^{\circ} \\
20^{\circ} \\
10^{\circ} \\
10^{\circ} \\
20^{\circ} \\
10^{\circ}\end{array}$ & $\begin{array}{l}14,701.00 \\
26,361.00 \\
31,613.00 \\
66,103.00 \\
37,982.00 \\
96,911.00\end{array}$ & $\begin{array}{l}\text { Titanium } \\
\text { Titanium } \\
\text { Titanium } \\
\text { Titanium } \\
\text { Titanium } \\
\text { Titanium }\end{array}$ \\
\hline
\end{tabular}

Mfg. Model No. Hot GPM Cold GPM Approach Cost Material

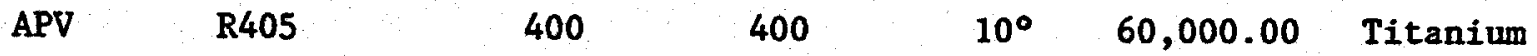

Optional Primary

(Shell-in-Tube)

Mfg. Model No. Hot GPM Cold GPM Approach Cost Material

Houston Counter-flow

Heat Floating Head

400

400

$10^{\circ} \mathrm{F}$

$83,000.00$

$304 \mathrm{~S} / \mathrm{S}$

Titanium

Hot 
Tranter SUPERCHANGER Model UX-216-HP-216 plate and frame type heat exchanger complete with 863.8 square feet of heat transfer surface, 216 plates fabricated of Titanium, nitrile gaskets, carbon steel guide bars, zinc plated carbon steel tie bolts and zinc treated carbon steel painted protective shroud. The plates are arranged for three (3) passes on the hot side and three (3) passes on the cold side and the unit is designed to perform in accordance with the attached specification sheet. The unit is supplied with one (1) four-inch Titanium straight, one (1) four-inch 316L straight, one (1) four-Inch Titanium elbow and one (1) four-1nch 316L elbow nozzles.

Tranter SUPERCEANGER Mode1 UX-416-EP-250 plate and frame type heat exchanger complete with 2028.8 square feet of heat transfer surface, 250 plates fabricated of Titanium, nitrile gaskets, carbon steel baked epoxy enamel painted frame, hard chrome plated carbon steel guide bars, zinc plated carbon steel tie bolts and zinc treated carbon steel painted protective shroud. The plates are arranged for three (3) passes on the hot side and three(3) passes on the cold side and the unit is designed to perform in accordance with the attached specification sheet. The unit is supplied with one (1) four-inch Titanium straight, one (1) four-inch 316L straight, one (1) four-inch Titanium elbow and one (1) four-inch $316 \mathrm{~L}$ elbow nozzles. 


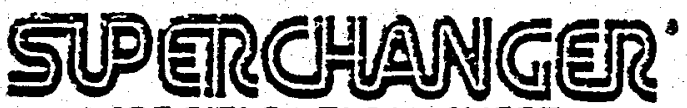 \\ SPECIFICATION SHEET}

CUSTOMER NEW MEXICO STATE UNIU

EOX 3 - FSL

LAS CRUECES, N. M. 88003
FROPOSAL NO. SC-10473-3=

ENGINEER- - C.F.

OATE-

MODEL NO. UX-21S

FRAME TYFE. HF

FATES FEF: UNIT 21S

MO. CF UNITS IN PARALLEI 1

MEAT TRANSFER AIEA GSI.B SQ.FT. PER UNIT

- PERFORMANCE

FLUTD CIRTLLATED

TOTAL FLCW RATE

LAIT FLOW RATE

SPECIFIE HEAT

SFECIFIC DFAUITY

THERMAL CONDUCTIUITY

UISCOSITY

THLET TEMPERA TULVE

CUTLET TEAFERATUFE

PRESGURE ERIPP

OFERATIMG RRESSURE

HEAT EXCHANGET

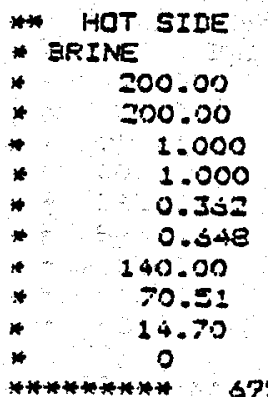

* COLL SIJE

* WATEF 200.00

200.00

0.799

0.794

$0.3=3$

0.723

50.00

150.00

14.75

14.7

67535.54 .0

$\rightarrow * * * * * * *$

GPM

CFM

BTU/LB.DEG.F

- BTU,HF _ET DES.F

- cop. at aug. temir

- CEG.F

CEE.F

* posia

fosto

BTU, HF

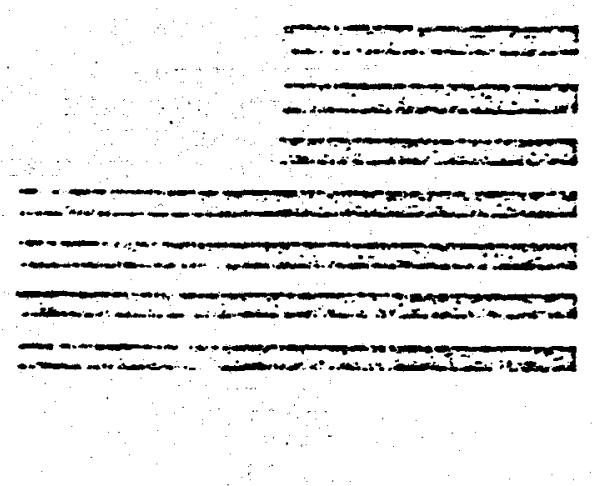

- REMATEKS

ERAR:S

BCLTS

* Mek

- titjizisl

* TIT

* CS epdXY paINTEj

- haRd ce flaiteI cs

* in flated cs

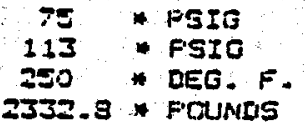

- Fisto

DEG. F.

PAINTED
LAIEI CS
CS

- - - -

Figure vIII-I

The SUPERCHANGER sertermsnes zuarantes as based an the aceuracy $\boldsymbol{f}$ ine aeta aresanted above. and the eustemers abulity io

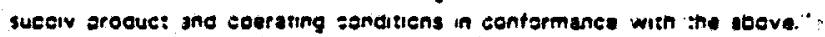




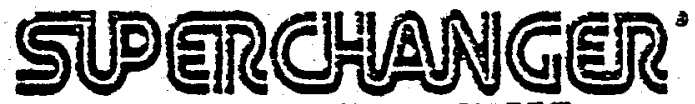 \\ SPECIFICATION SHEET}
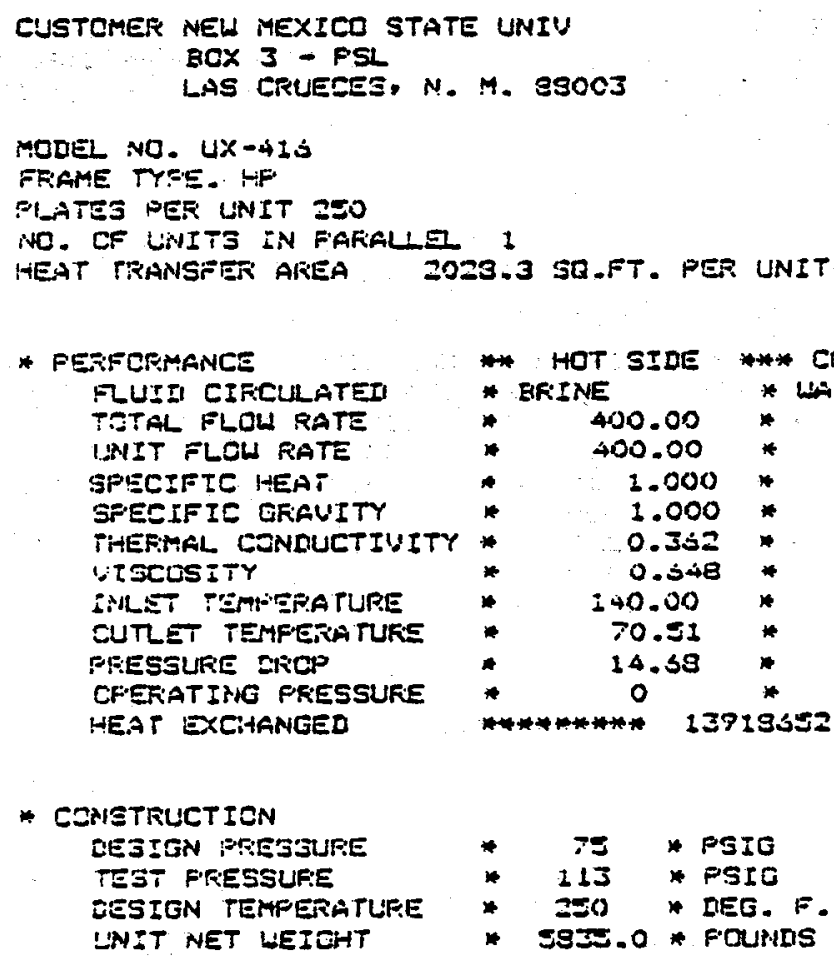

* Meir

* titijisl

* TET

* cs efoxy fainted

* hafil ca flatej cs

- zn plater cs
PRCPOSAL NO. SC-10473-32

ENGINEER-- C.P.

UATE-DO-O $46 \pm 230$

- Beirains

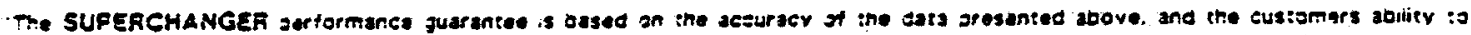

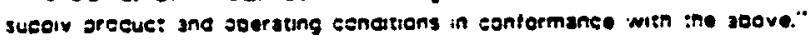

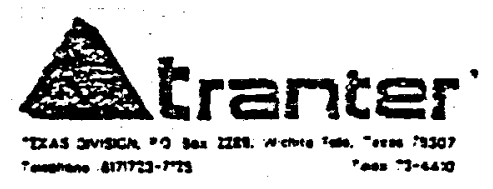




\section{SせP]}

EUSTOMER NEW MEXICO STATE UNIU

BOX 3 - PSL

LAS CRLEEES. N. M. 83003

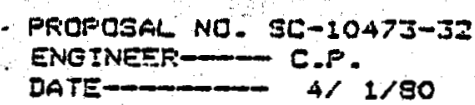

MOLE NO. UX-215

FFAKE TYFE. HP

DATES FER UNIT 210

ND. OF UNITS IN FAKALLE

HEAT TRANSFER AREA SUJ.8 SQ.FT. FER UNIT

* performance

FUII CIFCLLATED

TOTAL FLOL RATE

LNIT FLOL RATE

SPECIFIC HEAT

SFECIFIC GRAUITY

THERHAL CCNDUETIUITY

UISCESITY

ENLET TEMPEFATURE

CUTLET TERFERATUFE

FRESSURE DROP

OFERIATING PRESSURE

HEAT EXOHANGED

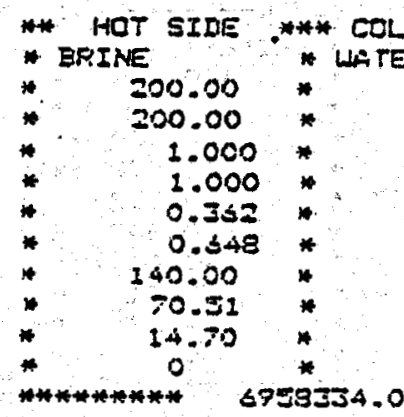
SIDE **
0.794
0.353

300.00 GFM

$200.00 * \mathrm{GFM}$

0.799 * ETU/LD.DEG.F

* C.f. at avg. tamf

B).00 + DES. F

130.00 HEE. F

14.73 * PSIS

0 * FGIC

* ecnstaliction

DESIEN PRESSURE

TEST FRESSURE

DESIGN TEMPERATURE

LNIT NET WEIGHT
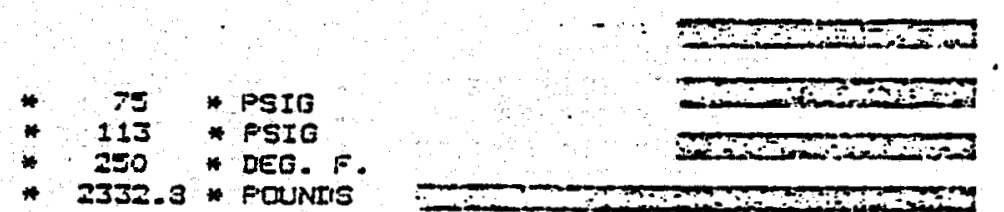

- Matefials

GASNETS

NOZZZLES

FLATES

FRAME

EARS

BOLTS
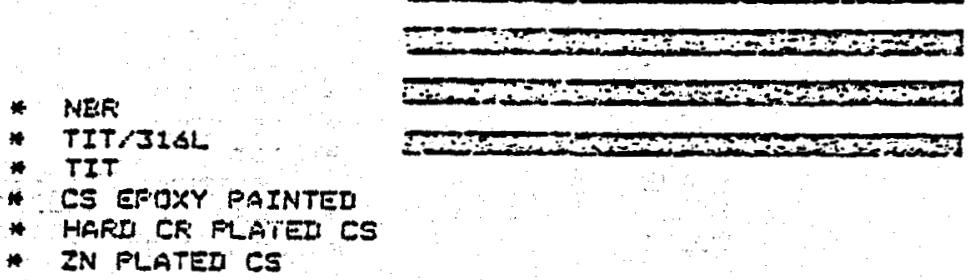

* remarks

EIgure VIII-3

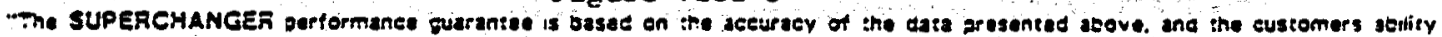
sucoly broduct and opeegting sanditions in esenformance with the above."

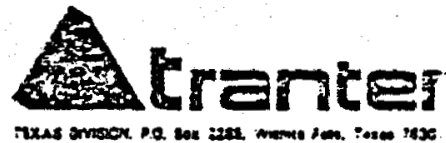




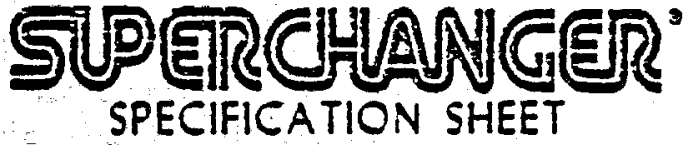

CUSTCMER NEW MEXICD STATE UNIU

EOX $3-F S t$

LAS CRUECES. N. M. G8003

- PROFOSAL NO. SC-10473-3Z

ENGINEER-D- C.P.

IATE- 4 - 1,90

MOLEL NO. UX-41S

FRAME TYEE. HP

PLATES PER LUNIT ZEO

NO. OF UNITS IN FARALLEI I

HEAT TRANSFER AREA 2023.3 SO.FT. PER UNIT

* feftrormance

RUID CIRCULATED

TOTAL FLOL RATE

LAIT FLOW RATE

SPECIFIC HEAT

SPECIFIC GRAUITY

THERMAL CONDUCTIUITY

UISCDSITY

INLET TEMTERATURE

CUTLET TEMFERATURE

FRESTLFE TROP

GFETATING FRESSURE

HEAT EXCHANGED

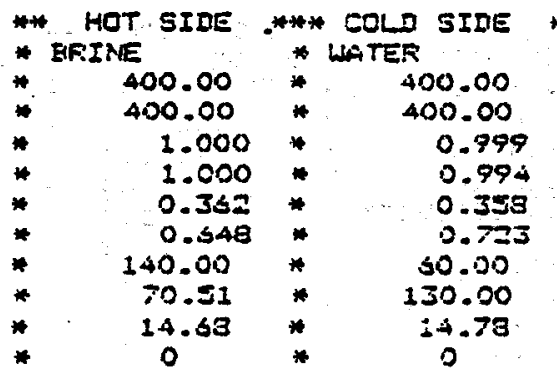

$* * * * * * * * * 13719552.0$
GPM

GPH

BTULS.DEG.F

- BTU.AHR.FT.DEg.F

* c.p. at aug. tenf

- DEj . F

- LEG. :

- Pegsa

FSIG

BTU $f$ :TR

- construction DESIGN PRESSUPE TEST FRESSUFE JESIGN TEMFERATURE UNIT NET WEIGHT

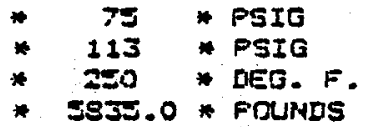
SESE. 0 * FOUNDS

* taer

* TITijisl

* TIT

* cs epoxy patnten

* hafi cé flated co

* in plated cs

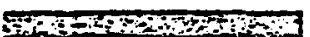

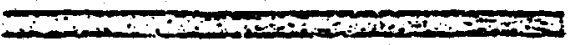

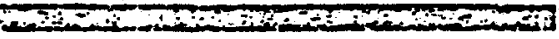

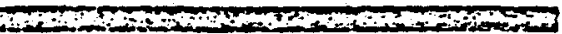

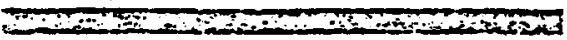

FLATES

FRAME

EAF:S

EOLTS

* remarks

Figure VIII-4

The SUPERCHANGER performance guarantes is bused on the aceursey of the sata gresented above. and the customars ablity supety proctuct and egerating candittons in sonformance with the ibove."

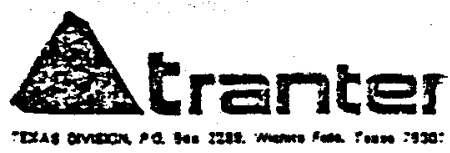




\section{SCHEMATIC OF HEAT EXCHANGE COMPLEX}

Figure VIII-5

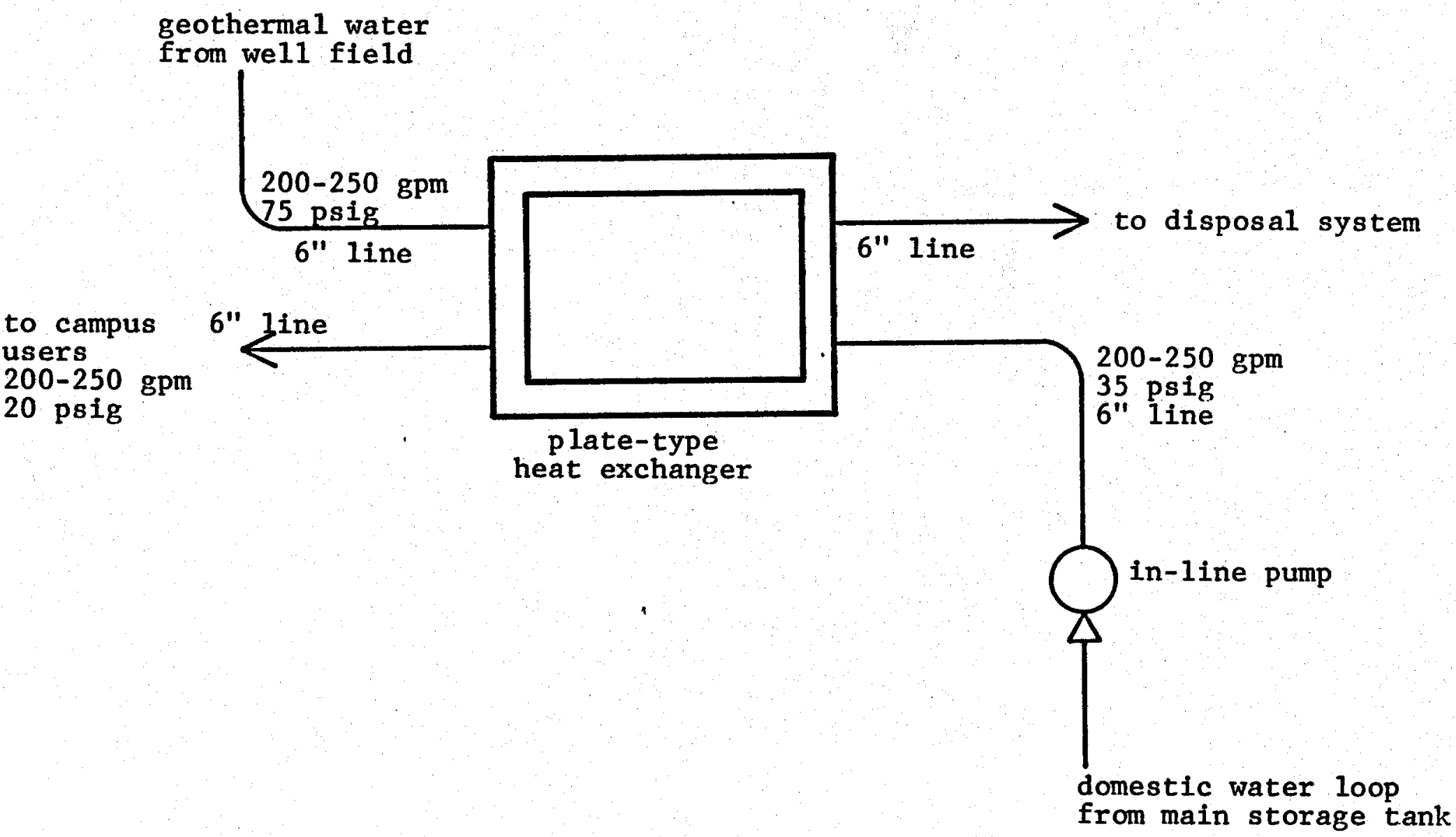




\section{Genera1}

A control system has been designed which makes maximum provision for local read-out and control for system testing and trouble-shooting, and to facilitate access for repairs. Concurrently, however, a need exists to have remote read-out and control, with a centralized automated system. This portion of the control system, moreover, must be compatible with the computerized control system now being designed for the NMSU Physical Plant Department (PPD) for overall control of steam, chill water, and domestic water systems. It is projected this new PPD system will be installed in the same time frame as the geothermal heating system.

The final design for the new PPD system is not expected to be available until late Apri1 1981. The geothermel system compatibility with this new system will then be adjusted, and final design for procurement of the geothermal system controls will be accomplished in early summer 1981 .

In order to provide continuity of operations, the system design Incorporates isolation valving and local data read-out for minor system malfunctions, to permit on-site technician repairs and trouble-shooting. In addition, the essential data elements are to be fed into a centralized computer processing unit for alarms and central control. 


\section{Design Concept}

a. Localized Control

(1) The well field controls will be colocated with the gas controls in the equipment well alongside the gas separator. However, each well pump also will be controlled by an external pressure sensor/switch which will stop the pump if line pressure exceeds a preset limit. This line pressure in turn will respond to a flow indicator/control valve, controlled by liquid level in the gas separator tank. A separate liquid level control will be installed for each well pump. Well pumps must be manually restarted after shut down. All system components at the gas separator complex will have isolation valving installed. In-line circulation pumps are installed in parallel, for 100 percent redundancy for out-of-service conditions. See Figure IX-1 for a schematic representation.

(2) Controls for the heat exchanger complex incorporates the critical functions for this part of the system. Rey parameters for temperature and flow of the inlet and outlet geothermal water, and the feed supply of domestic cold water are designed for both local and remote indication. Geothermal water flow through heat exchanger is controlled by a power-operated valve on the discharge side, to assure water-full condition in the exchanger. The cold water supply line has a local and remote flow indicator. The power valve for the cold water supply, however, is located at the downstream inlet to the hot water storage tank. Again, this is designed to provide water-full conditions in the heat exchanger. To provide a positive head in the cold water side, and to provide sufficient pressure to accommodate the pressure drop across the heat exchanger, two 15-hp in-line pumps are installed in parallel. This provides 100 percent installed redundancy in the event of single pump 
failure. Switch-over to the auxiliary pump is planned for local control, although an option exists for automatic switch with local verification. See Figure IX-2 for details.

(3) The hot water storage tank is the single most complex installation. (See also the section of this report which provides full details of the design.) Provisions are made for isolation valving for local repair and trouble shooting, and for semiautomatic controls for such feetures as the emergency standby gas fired boilers. Two in-line constant output pumps are installed in parallel on the output side of the storage tank. This provides 100 percent installed redundancy in the event of single pump fallure. Switch-over to the auxiliary pump is planned for local control, although an option exists for automatic switching with local verification. See Figure IX-3 for details.

(4) Local control only is designed for each separate building retrofit.

(5) To provide motive power for the power-operated valves, small air compressors will be installed at the gas separator and heat exchanger complexes to provide compressed air for the pneumatic valves. The location of the hot water storage tank facilitates a connecting line to the tunnel compressed air system.

\section{b. Remote Indication and Controls}

(1) The well-field and gas separator complex is designed for semiautomatic contro1. System shut-down is automatic in the event of component fallure. However, system restart requires local control. System shut-down w1ll be signaled to a control point by the flow indjcator control at the discharge side of the geothermal loop through the heat exchanger. Four temperature and two flow indicators will be 
transmitted from the heat exchanger complex to the centralized computer processing unit. Use will be made of 10- to 15-pair cable, to provide spare capability. Type of signal and details of this part of the system are dependent upon the design of the PPD Centralized Control System.

(2) From the hot water storage tank, three temperature and three flow signals will be transmitted to the centralized computer processing unit. Again, use will be made of 10- to 15-pair cable to provide spare signal capacity. Intent is to provide key parameters for signaling system malfunctions, and to provide capability for the central system to control flow, and to direct on-site visits for verification or repair of minor failures.

(3) Central Processing Unit - As envisioned, a maximum of 14 channels of information will be stored. If separate channels are required for alarms and controls, this total would increase to approximately 25 channels. Informal coordination with PPD, and with the engineering firm designing the PPD system indicates that adequate capability will exist for this data load. 


\section{PLANNING SCHEMATIC INSTRUMENTATION AND}

\section{CONTROLS GAS SEPARATOR COMPLEX}

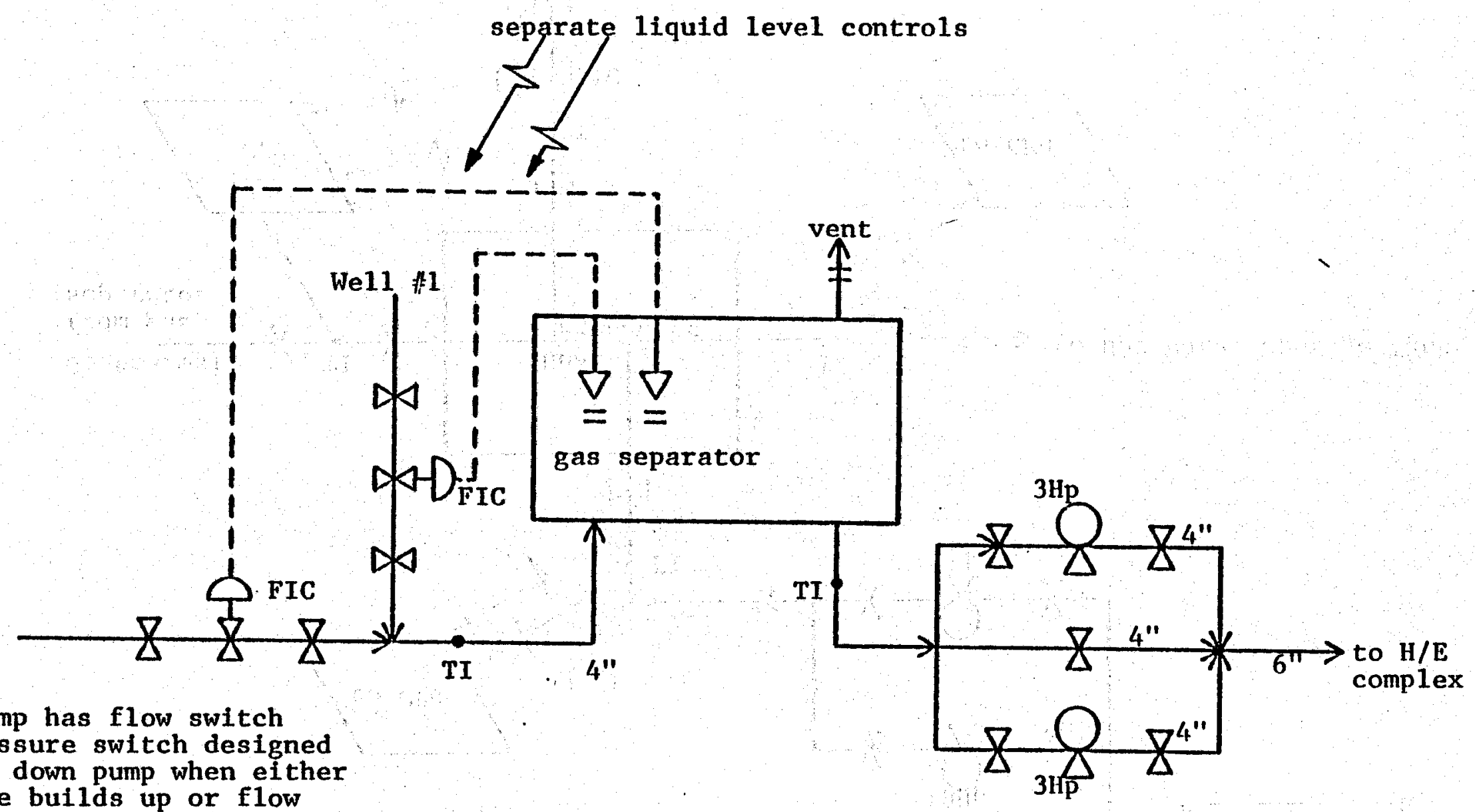

Note:

Each pump has flow switch

and pressure switch designed to shut down pump when either pressure builds up or flow

stops. These are connected

with pump control wiring. 
PLANNING SCHEMATIC INSTRUMENTATION AND CONTROLS HEAT EXCHANGER COMPLEX

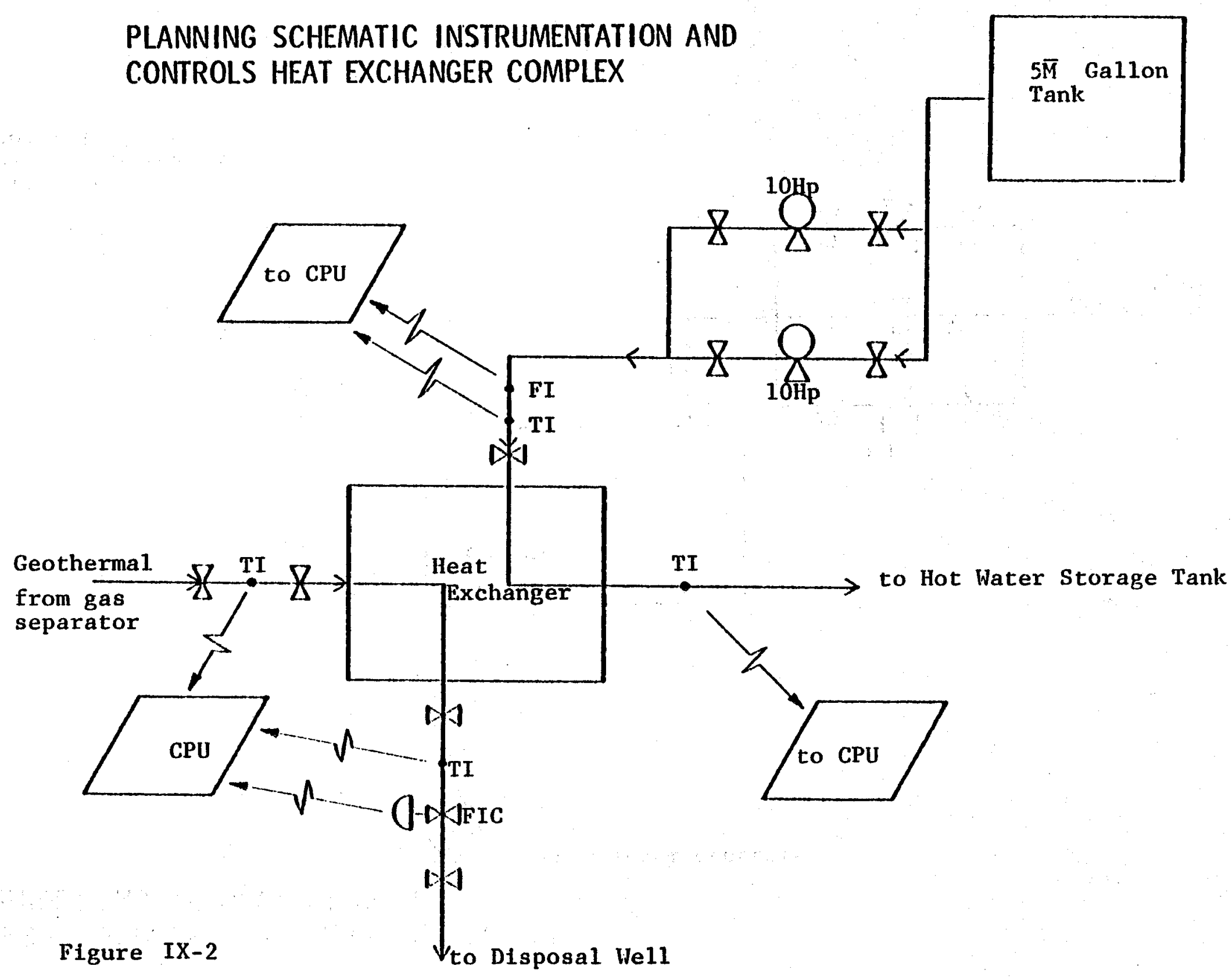




\section{PLANNING SCHEMATIC INSTRUMENTATION AND}

CONTROLS HOT WATER STORAGE TANK

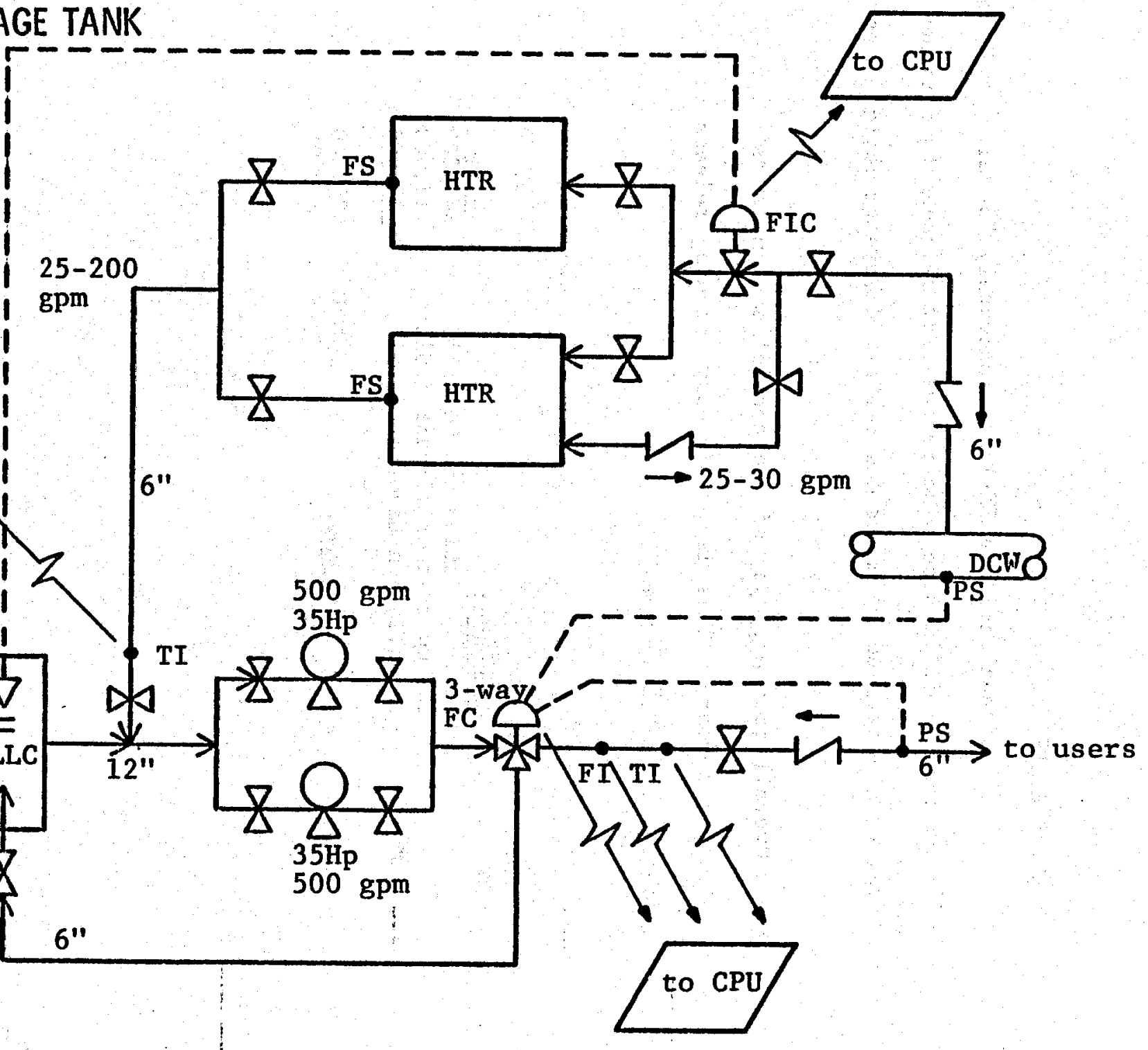




\section{Overall Summary}

a. As can be seen on Table IX-1, approximately 73 valves and controls will be installed, in pipe size ranges from 2 inches to 6 inches. This total will be revised after the centralized PPD system design is analysed.

b. Overall cost estimate of the control system is as defined in the following summary. This is preliminary, pending release of the design package on the PPD system.

Component Instrumentation and Controls 10,000 feet of 15-pair cable Installation Labor
Cost

$\$ \overline{49,200}$

15,000

25,000

Total $\$ 89,200$ 
Table IX-1

Instrumentation and Control Package

(Preliminary)

Approximate

Quantity

Cost

Liquid level controls

3

$\$ 1,500$

Flow indicator control

5

5,000

Flow indicator

1

1,000

Three way modulating valve

2 (1 spare)

3,000

Temperature indicators/sensors

9

1,000

Flow switch

2

500

Pressure switch

2

500

Pressure sensor

4

500

Vent valves

2

1,000

3 HP pumps

2 (1 installed spare)

3,000

10 HP pumps

4 (2 installed spares)

7,200

35 HP pumps

2 (1 installed spare)

5,000

Manual valves

35

17,500

Check valves

10

2,500

73

$\$ 49,200$ 


\section{Section $\mathrm{X}$}

\section{GEOTHERMAL DISPOSAL SYSTEM DESIGN}

\section{General}

A comprehensive program of Ilterature research, laboratory testing, and field experiments was conducted to solve the problem of use or disposal of the geothermal water. This section addresses the problem and defines follow-on research which will be completed to determine the economic feasibility of reuse of the geothermal water after heat is extracted, and to provide a foundation for the construction of the disposal system.

\section{Overa11 Objectives}

The final use of the geothermal water depends on several factors. Deposition and fouling of the heat exchangers must be minimized. After heat exchange, it would be preferable to use the water for irrigation of the golf course. If the water cannot be used for irrigation, a safe, acceptable disposal system becomes a necessity.

a. Several tentative solutions are under consideration for minimizing the fouling of the heat exchangers. Dilute sulfuric acid can be used to acidify the water to retain the solids in solution. An alternative substance, Monsanto Dequest 2000 or 2060 , could also be used to keep the solids in solution. A series of controlled laboratory tests is underway to test various chemical additives, to determine effectiveness and cost of the treatments. 
b. The acidification of the water to reduce heat exchanger fouling might facilitate follow-on use of the heated water for irrigation of the golf course.

If the golf course well cannot be used for disposal of the acidified water, the water will have to be treated to accumulate and dispose of residues, or a reinjection well will have to be drilled elsewhere.

\section{Alternative Design Concepts \\ a. Description}

(1) Use the existing golf course well, and in-place irrigation pipeline, to reinject the geothermal water after required treatment.

(2) Drill a new disposal well, in a portion of the aquifer contiguous with the University Center (President's house) we1l, and use this well for reinjection immediately after the geothermal water has passed through the primary heat exchanger.

(3) Treat the geothermal water to remove some portion of the dissolved solids, and use this weter for irrigation of the golf course.

\section{b. Assumptions}

(1) The golf course well will be approved as a disposal well either with waiver or unconditional use.

(2) Treatment of the geothermal water would remove 400 to $600 \mathrm{ppm}$ of dissolved solids. This treatment could be designed to gain water quality adequate for direct irrigation use on the golf course.

(3) Treatment of the water would require use of at least two treatment ponds, each one acre in area. In concept, the water would be treated with a chemical agent, which would cause precipitation of 
undesired solids. The water would then be pumped to the second pond, for further treatment before being reinjected or used for irrigation.

(4) An existing 6-inch transite irrigation pipeline could be rehabilitated for use as the treatment system circulation loop, connecting with the disposal well.

(5) If a new disposal well must be drilled, this well would be placed in the general vicinity of the heat exchanger complex, and would be 450-500 feet deep, capable of accepting up to $500 \mathrm{gpm}$ of reinjected fluid.

(6) Using either the existing well, with treatment ponds, or the possible new well, a large reinjection well pump would be required.

(7) Usable land is avallable for the required two or three, one-acre treatment ponds; and the location of these ponds will facilitate golf course use.

\section{Description of Golf Course Well}

Figure $X-1$ is a schematic representation of the NMSU Golf Course Well. This well was drilled in 1961 and was pumped continuously at 550-650 gpm for ten years. The water was moderately saline (1450-1650 ppm TDS) and appeared to get increasingly saline over the years of usage. The recorded water temperature during use was $24^{\circ} \mathrm{C}\left(75^{\circ} \mathrm{F}\right)$.

As can be noted from the Schlumberger $10 g$ and the schematic, the well was drilled to a depth of 607 feet. It was completed to a depth of 507 feet, with the lower 100-feet section of uncompleted well sealed off by $a$ spring-activated foot valve at 507 feet of depth. The screen section was designed with a series of stainless steel Johnson screens, interspersed with sections of blank casing. Screen section was placed at a depth range 
of 354 feet to 507 feet, with five separate screen sections totalling 83 linear feet of screen. The well was placed in an inactive status in 1971, and the pump was removed.

Figure X-2, which follows immediately after Figure X-1, is a copy of the Electrical $\log$ (Schlumberger) made for this well December, 1962. 
SCHEMATIC OF NMSU GOLF COURSE WELL

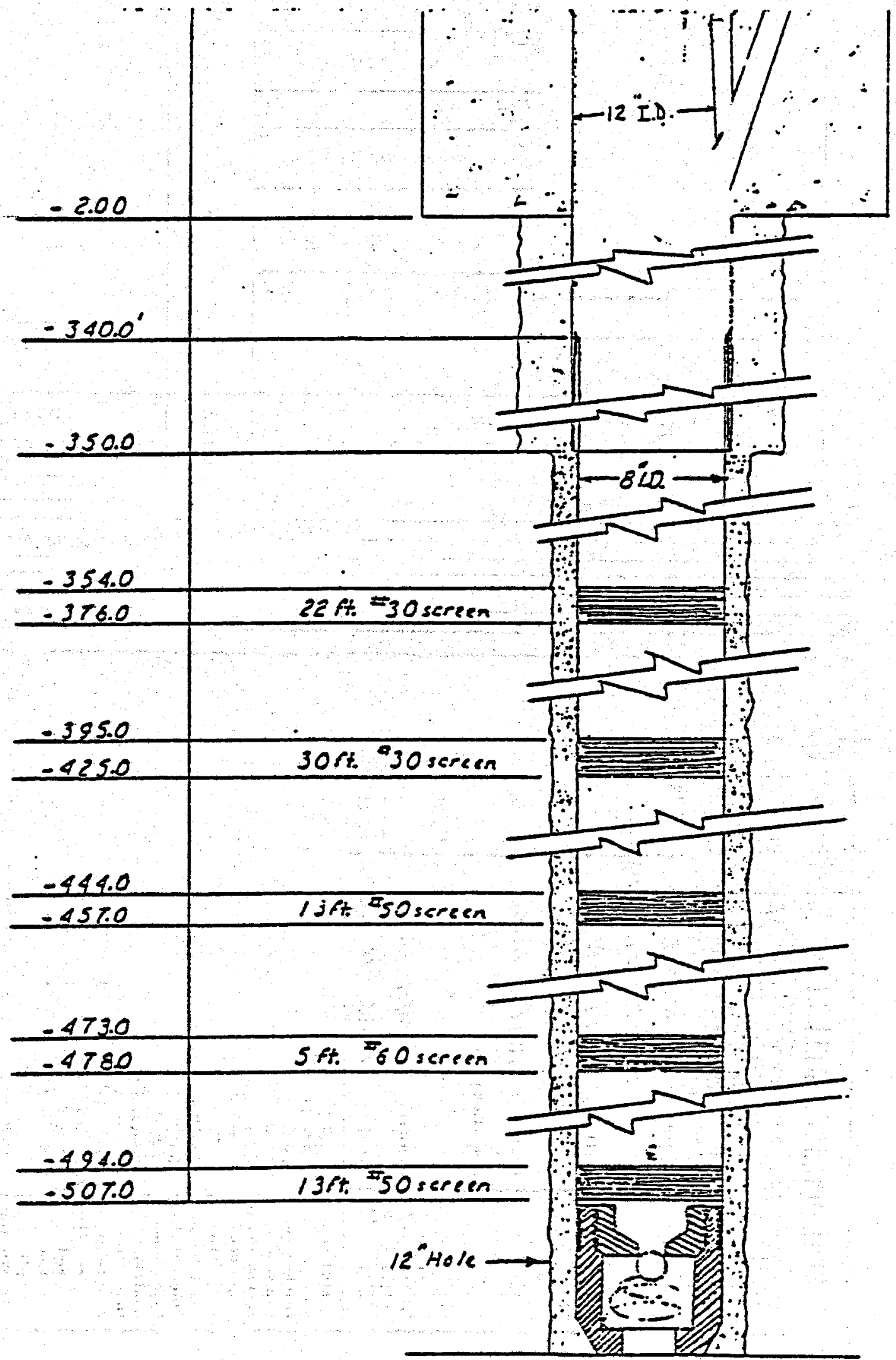

Figure $X-1$ 


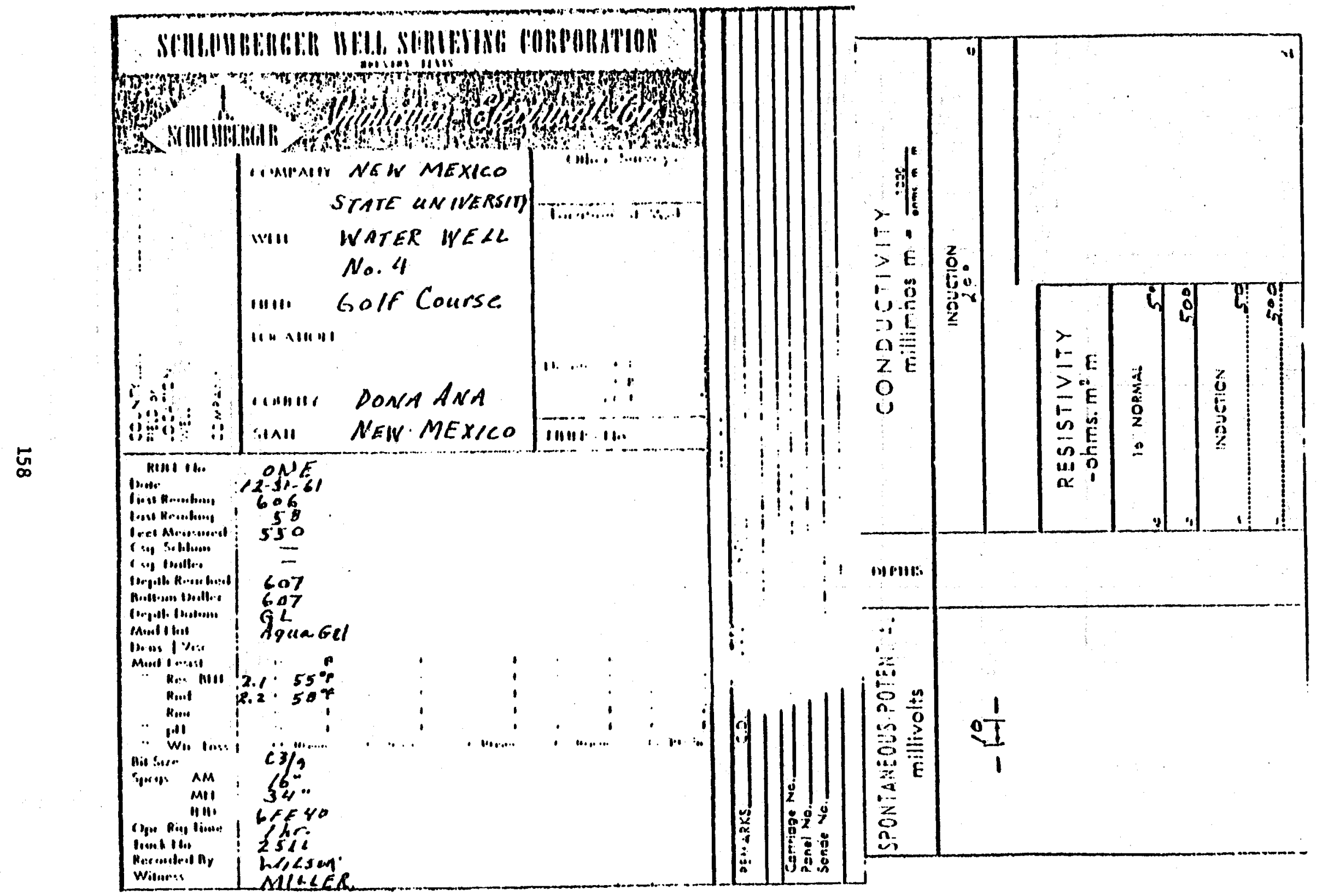




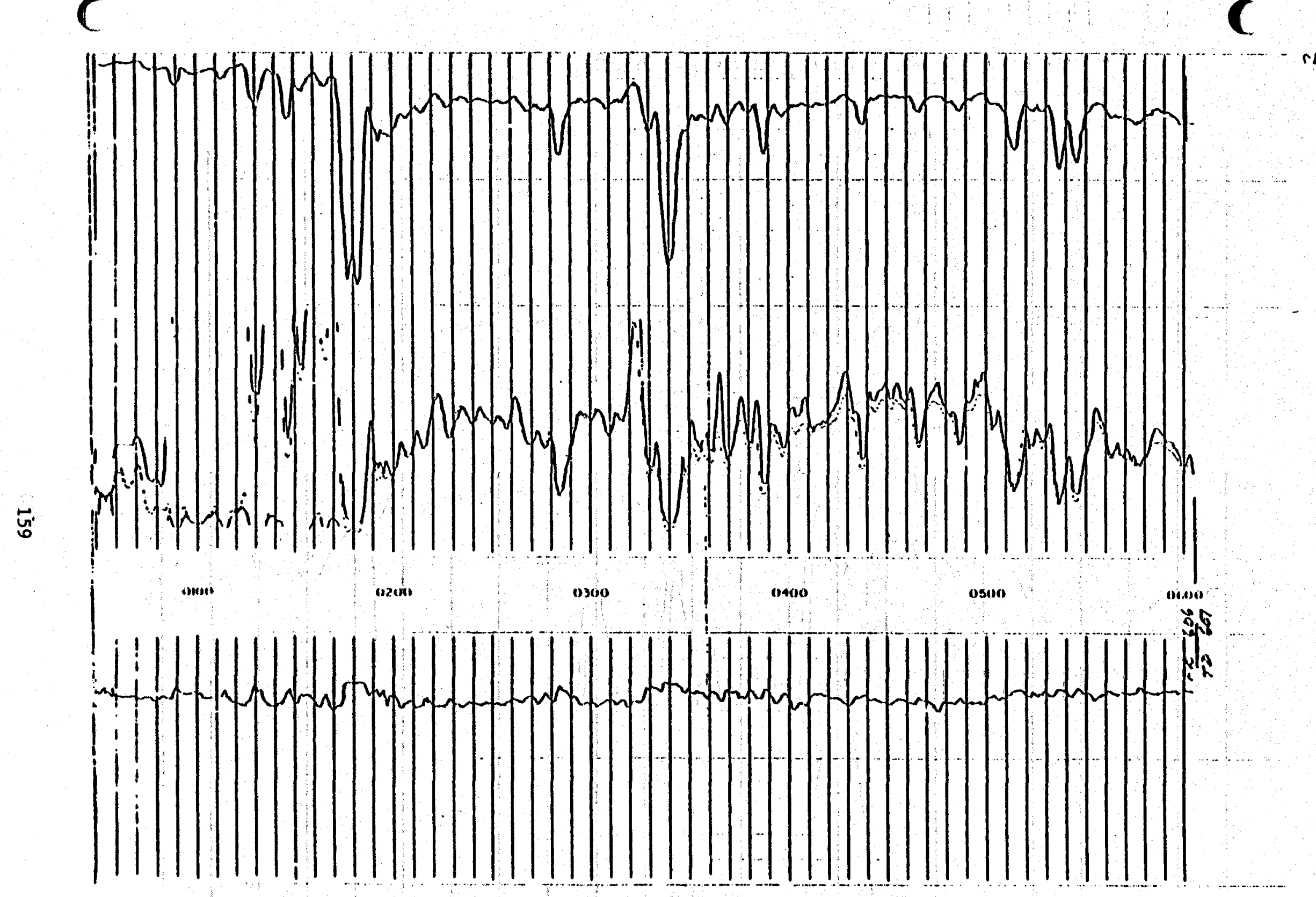

Figure $X-2$ (continued) 


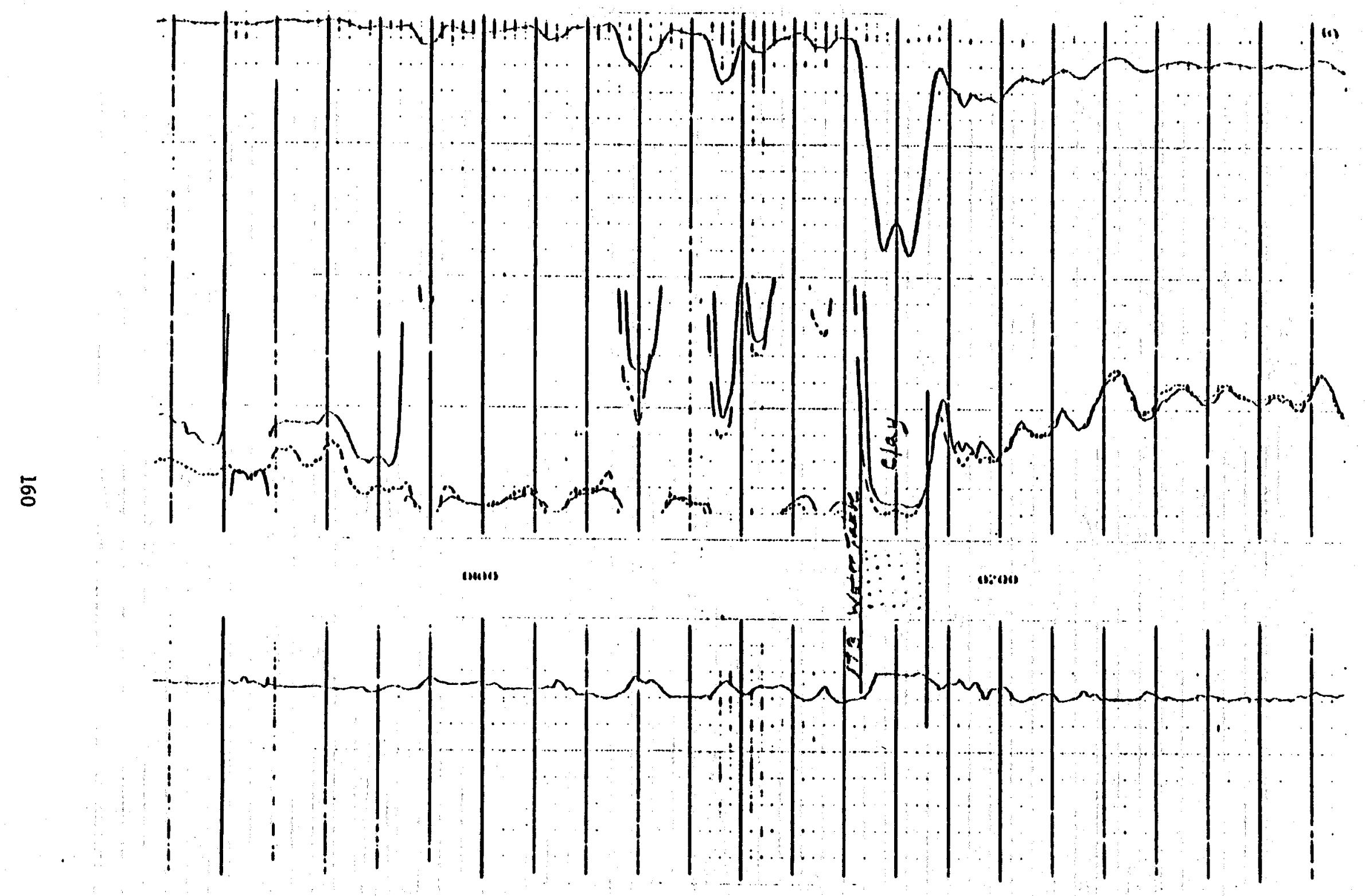

Figure $\mathrm{X}-2$ (continued) 


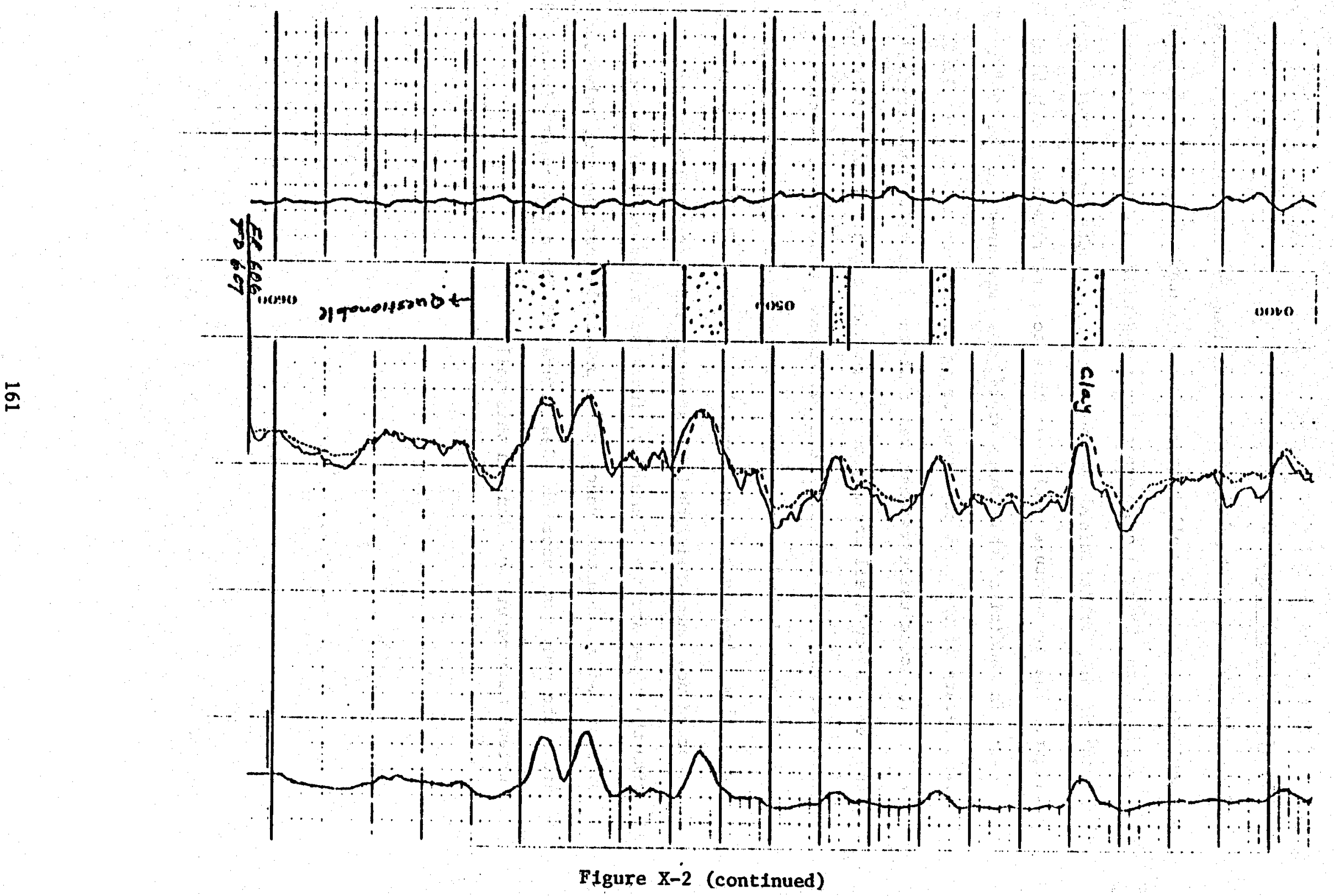




\section{Temperature Data}

Initial efforts to determine the conditions of this well for use as a geothermal disposal well centered around water quality and temperature measurements. Using a quick-reaction transducer, a down-hole temperature gradient $\log$ was obtained. Two interesting facts immediately came to light. The temperature probe was able to penetrate to a depth of 606 feet; in addition the temperature was measured to be $93^{\circ} \mathrm{F}$. The temperature of the well observed during production testing in 1962, was $75^{\circ} \mathrm{F}$. The conclusion reached was that the foot valve had corroded, and the well was open all the way to 606 feet of depth. We do not know when this foot valve was corroded to allow access to the lowest section. It is possible that the valve was rendered inoperative during the 10 -year period the well was in service. However, the fact that a higher temperature was recorded now, compared with 1961, suggests that warmer water is now mixing with the upper strata. Generally, increase in temperature is accompanied by increasing salinity. Hence, it is practable that the foot valve opened after the pump was recorded. See Figure X-3 for a representation of the current temperature gradient in this well. 


\section{GOLF COURSE WELL}

\section{TEMPERATURE GRADIENT MEASUREMENTS}

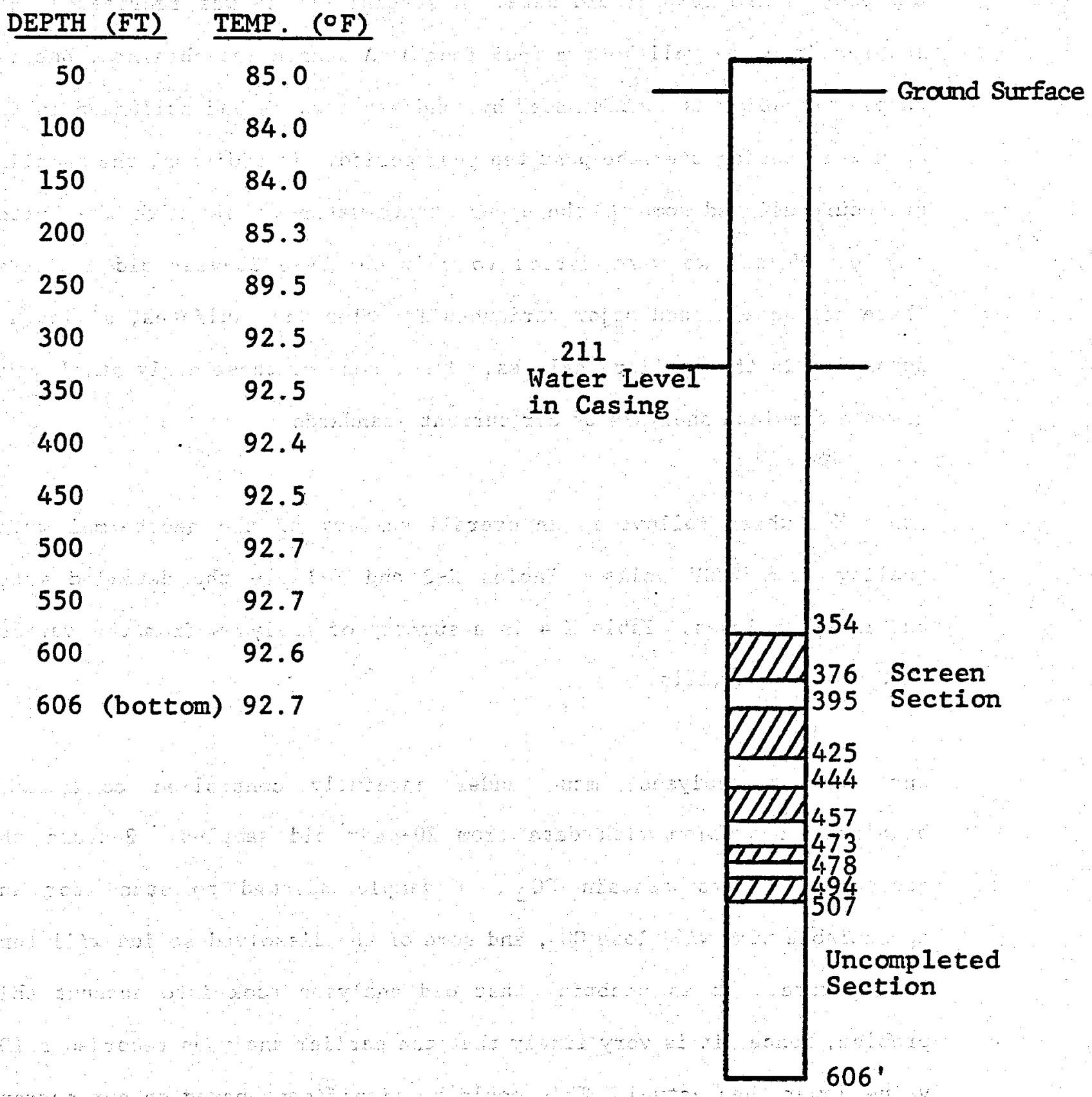

Figure $\mathrm{x}-3$ 


\section{Water Quality Analyses}

An effort was made to obtain a bottom-hole water sample, to test the currency of the 20-year old data. A special device was fabricated, and lowered into the well bottom (606 feet.) A sample was obtained, but the sample probably was contaminated by condensate which had collected in the open well casing over the past ten year period. In addition, the sampling procedure allowed some of the upper strata water to mix with the bottom sample. Hence, we were forced to rely on these 20-year old analyses. There are unexplained major variances in chlorides, sulfates, silica and potassium in the earlier analyses. Also, none of these early samples was given a complete analys is by our current standards.

Table X-1 which follows is an overall summary of the geothermal water quality from NMSU wells. Tables $X-2$ and $X-3$ are the detailed water chemistry analyses. Table $\mathrm{X}-4$ is a summary of anelyses from the various NMSU geothermal wells.

Our current analyses, made under carefully controlled conditions, highlight a problem with data from 20-year old samples. Because the geothermel waters contain $\mathrm{CO}_{2}$, a sample allowed to stand for any appreciable time will lose $\mathrm{CO}_{2}$, and some of the dissolved solids will tend to separate. It is doubtful that old analyses took into account this problem, hence, it is very likely that the earlier analyses recorded a TDS value lower than actual. This could be significant based on our current work. Before correcting waters analysis for the $\mathrm{CO}_{2}$ factor, the President's well was measured at $1704 \mathrm{ppm}$ TDS. The more rigorous analysis shows that correct value to be approximately $2070 \mathrm{ppm}$ TDS. Table X-5 is a 
comparison of the initial analysis on this we11, with the more vigorous analys is which take into account the $\mathrm{CO}_{2}$ mechanism.

As can be noted from Table X-1 the NMSU geothermal water is only moderately saline, and does meet standards for irrigation water. In fact, as discussed later in this section, controlled experiments are underway to determine if this water safety can be re-used as a source of water for the NMSU Golf Course. These experiments will require at least a year before valid conclusions can be made. For the interim, we plan to dispose of the water in the old golf course well is the best choice for a disposal well. 
Geothermal Water Quality

- Total dissolved solids: $2,000 \mathrm{mg} / 1$

- Primary standards exceeded: None

- Secondary standards exceeded (mg/1)

\section{Allowable : Measured}

Alkalinity

$30-500$

$505-512$

Sodium

200

$484-488$

Chlorides

250

$466-603$

Sulfates

250

292

Manganese

0.05

$0.05-0.11$

Iron

0.3

$0.43-0.78$

- See attached anelyses 
Table X-2

Water We11 Analyses

\section{Method}

Sampling

Date

$10 / 24 / 80$

$7 / 21 / 80$

$7 / 16 / 80$

Sampling

Date

$10 / 24 / 80$

$7 / 21 / 80$

$7 / 16 / 80$

Sampling

Date

$10 / 14 / 80$

$7 / 21 / 80$

$7 / 10 / 80$
Atomic Absorption

$\begin{array}{lll}\mathrm{Ca} & \mathrm{Mg} & \mathrm{Na} \\ (\mathrm{mg} / 1) & (\mathrm{mg} / 1) & (\mathrm{mg} / 1) \\ 75.6 & 19.0 & 445.0 \\ 75.3 & 19.0 & \end{array}$

$\mathrm{pH} \quad \mathrm{HCO}$

Co

$(\mathrm{mg} / 1)(\mathrm{mg} / 1)$

$6.85 \quad 616$

7.10

7.15

625

617

0

0

0

Total Hardness*

(mg/1 as $\mathrm{CaCO}$ )

248

246

249

\section{EDTA Titration}

$+4$

$\mathrm{Ca} \quad \mathrm{Mg}$

(mg/1) (mg/1)

$78.4: 12.7$

$77.6 \quad 12.7$

$78.8: \quad 12.7$

TDS Fe

(mg/1) (mg/1)

1936

1904

1913

\section{Total Alkalinity}

(mg/l as $\mathrm{CaCO}$ )

505

512

506

*Using EDTA Titration Results 
Table X-3

Water We1l Analyses

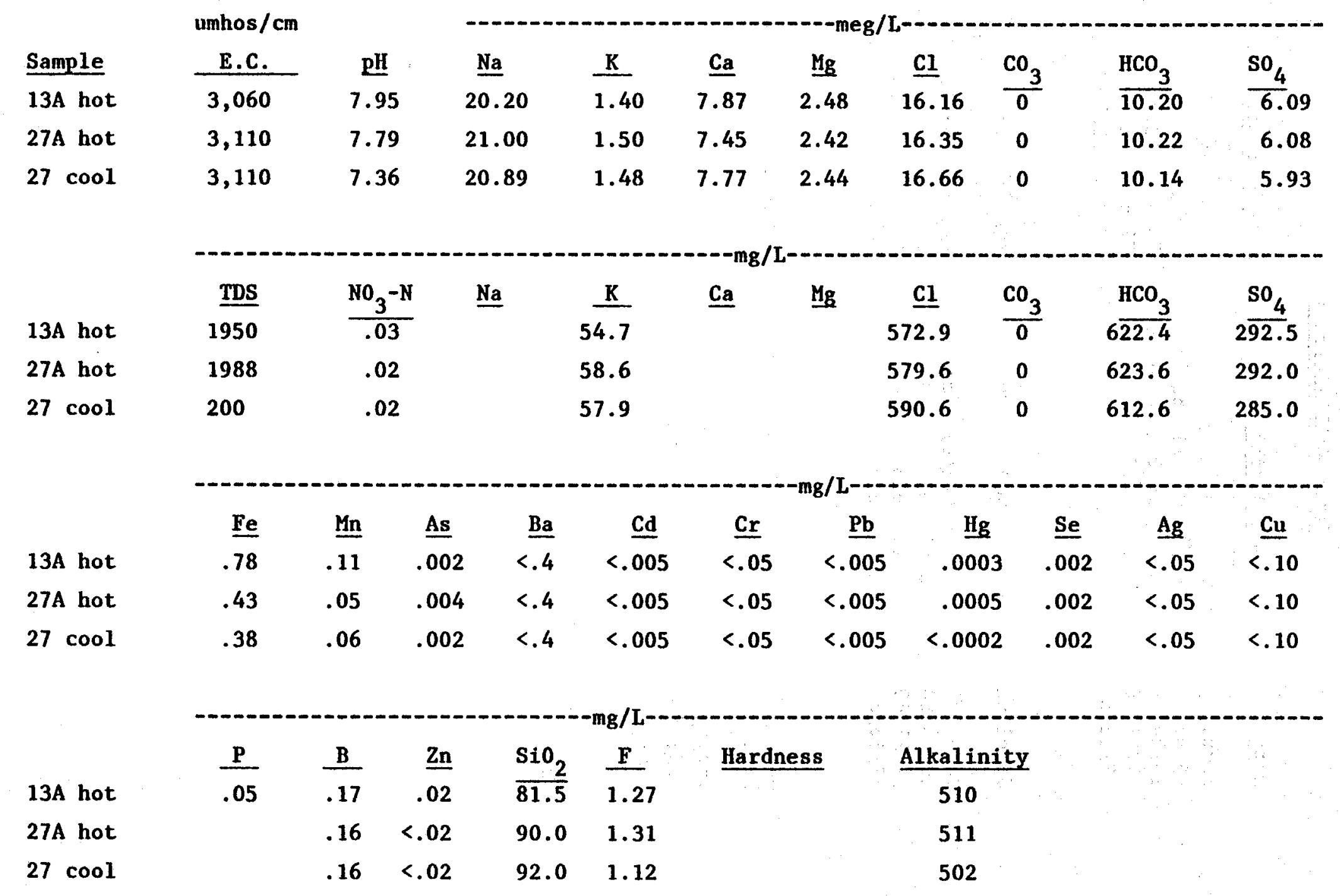


Table X-4

Well Water Analyses

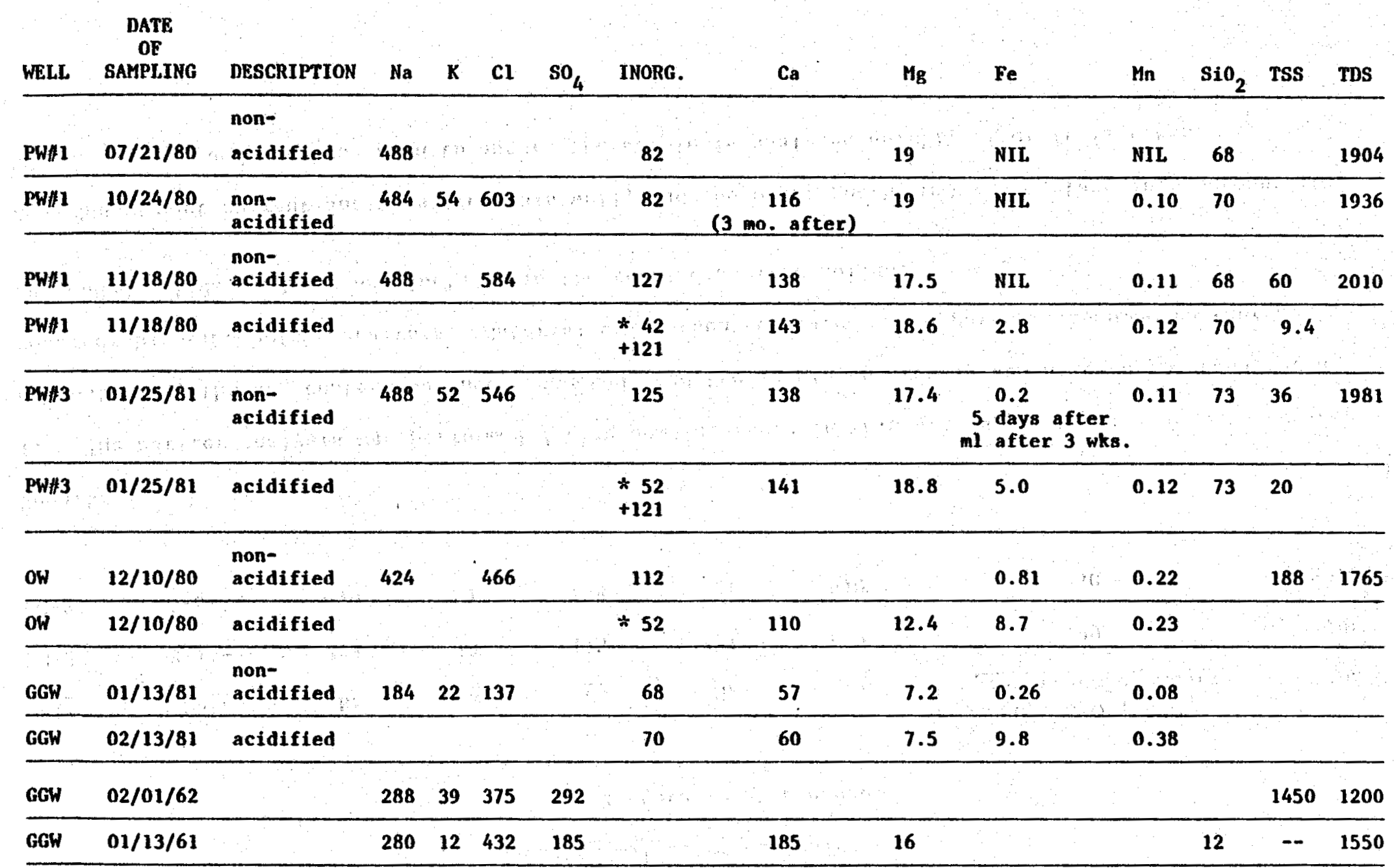

* IC analyzed $2 / 19 / 81$

Initially acidfied

+ Just acidified

NIL means below detection limit 
Table X-5

Geothermal Water Analysis

NMSU PG-2 (President's llouse)

\begin{tabular}{|c|c|c|c|c|c|c|c|c|}
\hline Well & Date & $\underline{\mathrm{Na}}$ & $\underline{\mathbf{K}}$ & $\underline{\mathrm{Ca}}$ & $\underline{M_{B}}$ & c1 & $\begin{array}{l}\mathrm{So}_{4}, \mathrm{SiO}_{2}, \mathrm{ICO}_{3} \\
\text { plus trace elements }\end{array}$ & IDS \\
\hline PG-2 & $8-14-79$ & 382 & 19 & 175 & 27 & 422 & 799 & 1704 \\
\hline PG-2 & $4-6-81$ & 450 & 51 & 188 & 21 & 610 & 750 & 2070 \\
\hline
\end{tabular}

\section{Remarks}

1. The earlier analysis was performed during pumping tests in this well shortly after it was completed. At that time, the $\mathrm{CO}_{2}$ content was not suspected, and the sample apparently was allowed to stand for a considerable time before analysis. Material which then separated was apparently assumed to represent suspended solids, and was not included in the total dissolved solids.

2. Subsequent current analyses from this well, and the other geothermal wells, take into account this $\mathrm{CO}_{2}$ mechanism, and care is taken to assure the sample is analyzed quickly after it is taken. 


\section{Reinjection Into Golf Course Well}

To confirm the engineering feasibility of the use of the golf course well for reinjection, down-hole photographs were obtained, and pumping tests were conducted. A conductivity test was then performed to demonstrate that this well is in the same aquifer as the other geothermal wells.

a. Down Hole Photographs

Before any intrusive tests were made, the well casing was visually Inspected. The visible portion of casing wes covered with rust and scale. Down hole photographs taken of the golf course well confirmed that there are no visible breaks in the casing down to 334 feet. Attempts were made to photograph the entire well to a depth of 505 feet, but the camera probe could not be inserted deeper than 334 feet. Scale was loosened by the camera probe, and fell into the casing, apparently creating a minor bridge at 334 feet of depth.

\section{b. Reinjection}

An injection test on the golf course well was conducted in February, 1981. The static water level in the well at test start was at 211 feet. A temporary connection was made to 6 -inch irrigation pipeline, and a turbine flow meter was installed. The irrigation system was then activated, and water at a known flow rate was pumped into the weil. This irrigation system draws upon the NMSU Campus domestic water supply system (370 ppm TDS). In1tially, at a flow rate of $470 \mathrm{gpm}$, back pressure in the irrigation system was 30 psig; there was zero back pressure in the well. At a flow rate of $250 \mathrm{gpm}$, the irrigation system had a back pressure of 70 psig; zero back pressure was recorded in the well. Static water level was determined by an anometer-type system, which had been calibrated in 
laboratory tests. The system consisted of 500 feet of $1 / 4-$ inch high pressure rubber hose, which was pressurized with air, and then connected to a pressure gauge. Water level was then measured by pressure differential by use of a pressure gauge. After 37 minutes of injection at approximately $470 \mathrm{gpm}$ the water level had risen to $64 \mathrm{feet}$. The flow was then reduced to $255 \mathrm{gPm}$ which caused the well to intake air. At an injection rate averaging $260 \mathrm{gpm}$ for 75 minutes the water level in the well stayed at a fairly constant 134 feet. The results of this test indicate that the golf course well has the ability to intake the injection rate proposed of $200 \mathrm{gpm}$ proposed for the disposal of the geothermal water.

\section{c. Conductivity Test}

The conductivity test was conducted to determine if all existing geothermal wells are producing from the same aquifer as the golf course well. Wells were interconnected by a continuous wire, and an electric current was passed through the wire. Resistance was measured by an ohm meter. Based on conductance values, it is concluded that the geothermal wells all are producing from the same aquifer. The following Table $X-6$ provides a summary of data, and within experimental limits of accuracy, the wells are producing from a single aquifer.

Table X-6

Conductivity Data, NMSU Geothermal Wells

\begin{tabular}{|c|c|c|}
\hline$\frac{\text { Well }}{\text { PG-1 }}$ & $\frac{\text { Depth (feet) }}{850}$ & $\frac{\text { Conductivity (mhos } / \mathrm{cm})}{3.11}$ \\
\hline $\begin{array}{l}\text { PG-2 } \\
\text { (University } \\
\text { Center Well }\end{array}$ & 500 & 3.17 \\
\hline
\end{tabular}

PG-3

860

3.16

Golf Course $\quad 606$

2.43 (Calculated from

Well

1961 water analysis) 


\section{Planned Disposal System}

a. Use of Golf Course Well. Figure $X-4$ is a schematic representation of the location of the golf course well, the existing transite irrigation pipeline, and pumping station, and the new heat exchanger complex. As can be seen, the heat exchanger can be connected with the irrigation pipeline in the vicinity of the pumping station, by installing approximately 600 feet of 6 -inch new transite piping. From an analysis of elevation head availability, less pressure drops through the system, sufficlent back pressure will be available at the outlet of the heat exchanger to provide motive force for the reinjection. This conclusion is reinforced by the results of the trial reinjection test. From observed data, the golf course well will accept easily up to $250 \mathrm{gpm}$ of fluid, and reinjunction occurs simply by the gravity resulting from the column of water cascading over the lip of the well. No reinjunction pump is necessary. 


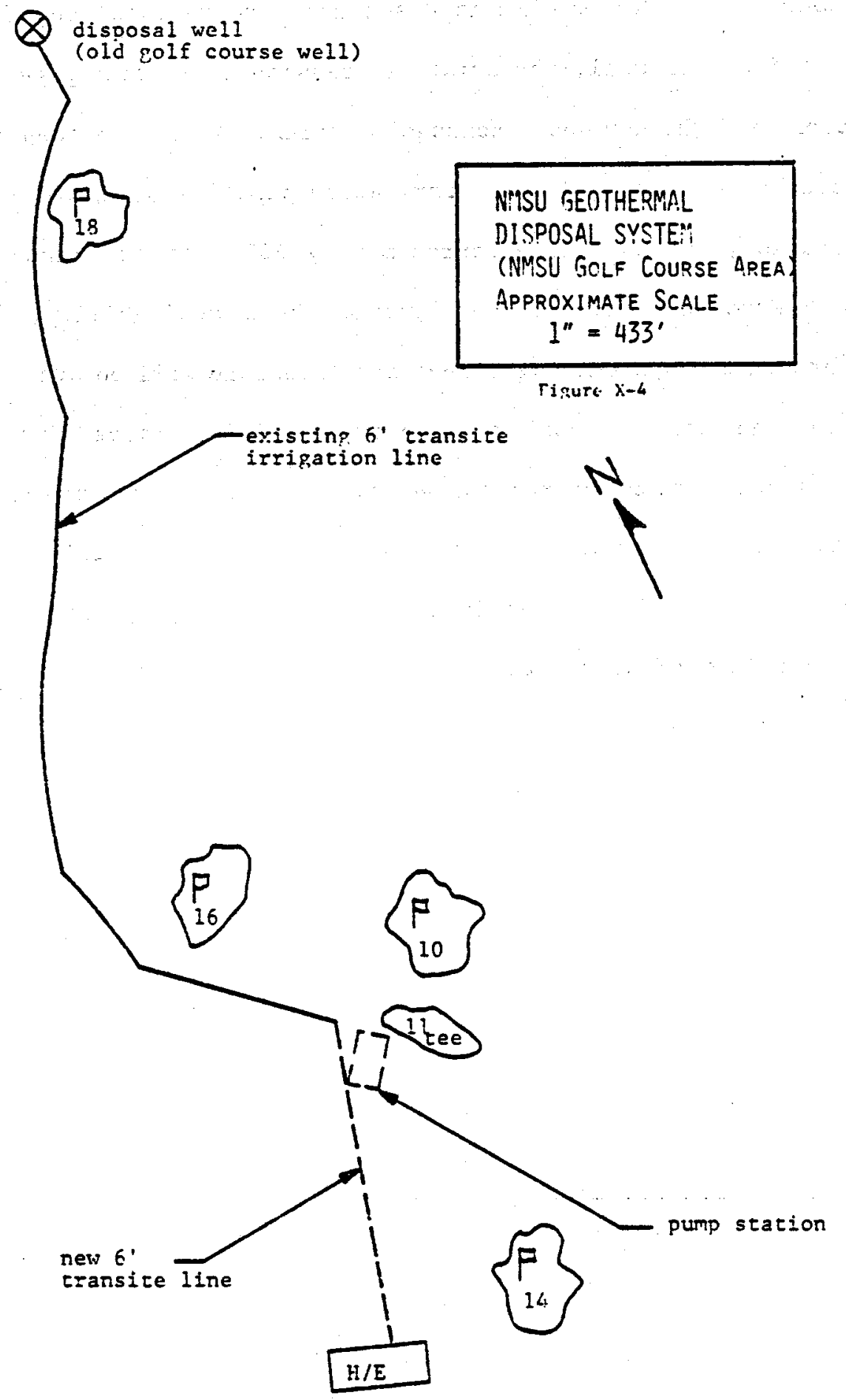


b. Disposal system with ponding. Figure $x-5$ illustrates the location of three treatment ponds, selected to obtain strategic use by the Golf Course. These are conceptual locations only, with final size and location to be determined by the Golf Course Superientendent. As can be noted, the three ponds would be interconnected with new transite piping, to allow the capability to use any two ponds simultaneously. In concept, one of the three ponds would be empty, in order to provide a means for sludge removal after precipitation of dissolved solids. It is emphasized that these are conceptual ponds only, because the ponds will be used only after controlled tests provide conclusive proof that treatment of geothermal water is economical, and that this treated water can be used for Golf Course irrigation without long-term deliterious affects on Golf Course fairways and other vegetation. A reinjection pump would be required to lift ponded water uphill to the disposal well.

c. Controlled test plots. In coordination with the Golf Course superintendent, locations have been selected for test plots. In concept, five or more test plots will be planted or sodded, and water from NMSU-PG-2 (University Center Well) will be used to irrigate the new sod. It is intended that at least two control plots will be used to determine effects of untreated water. Then, several test plots will be used to determine the utility of various chemical pre-treatments. Test plots would remain in place for a minimum of one full year, with a longer period desired. 


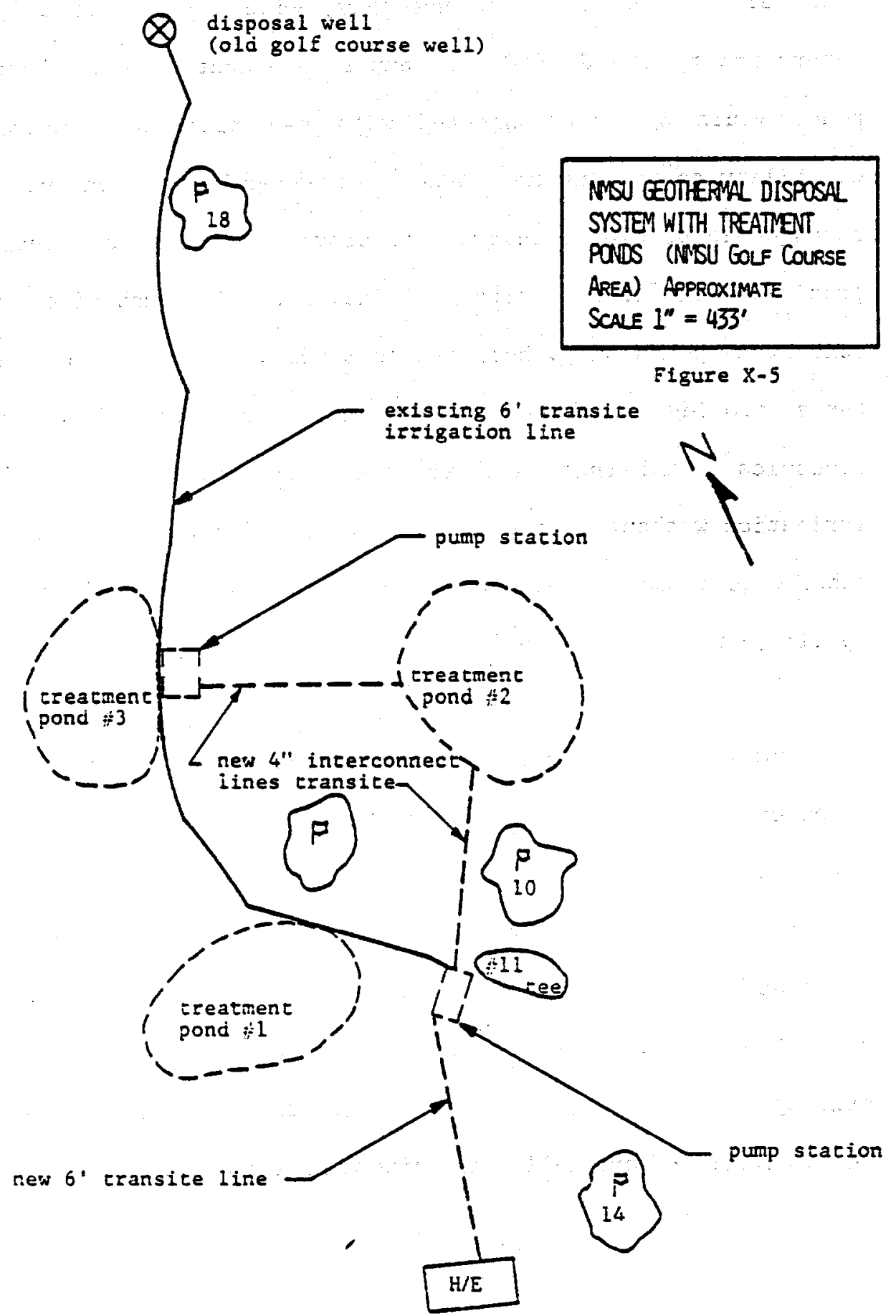




\section{Effects on Domestic Water Supplies}

\section{a. General}

A primary consideration in the use of the Golf Course Well as a disposal well is the potential for degradation of domestic water supplies. If the necessary and sufficient conditions exist to use the golf course well, then long-term effects on potable water supplies are expected to be minimal. These conditions are that the golf course will be in the same aquifer as the geothermal productive wells, and that the reinjected fluids can be confined to that aquifer.

\section{b. Nearby Wells}

A review has been made of all domestic water wells located near the golf course well. This review included Las Cruces City water wells and the domestic wells supplying the NMSU Campus. Consideration was given to all wells within a two-mile radius of the golf course well. Figure X-6 depicts the location of these wells, in relation to the golf course well. Table X-7 provides details on each well, including depth, ground elevation at the well head, dissolved solids as TDS, distance from the golf course well, and other information as available. 
LOCATION OF DOMESTIC WATER WELLS AND GEOTHERMAL WELLS ON AND NEAR NMSU CAMPUS

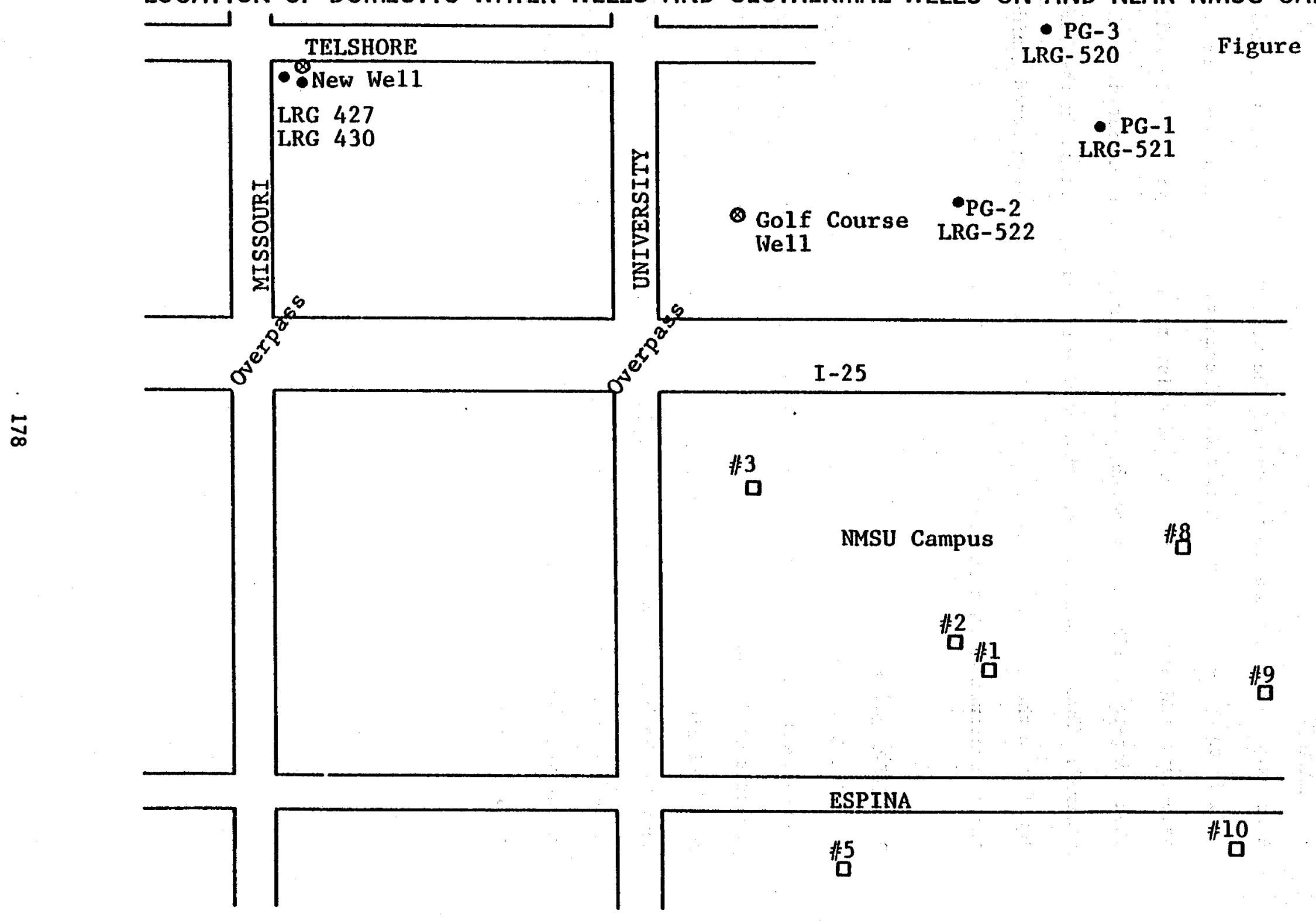


Table $\mathrm{X}-7$

Well Data, Las Cruces Wells and Campus Wells

Distance to

Golf Course

Well No. Depth Elev. TDS We11 (feet)

Remarks

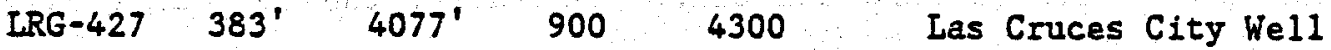

LRG-430 $526^{\circ} \quad 4077^{\circ} 900 \quad 4000 \quad$ Las Cruces City Well, to be abandoned

Current well condition open only to 250

LRG-520 $870^{\prime} \quad 4210^{\prime} 2000 \quad 3700 \quad$ NMSU PG-3, Geothermal production well

\begin{tabular}{llllll}
\hline LRG-521 & $860^{\prime}$ & $4164^{\prime}$ & 2000 & 3535 & NMSU PG-1, Geothermal production well \\
\hline LRG-522 $505^{\prime}$ & $4120^{\circ}$ & 2070 & 2500 & $\begin{array}{l}\text { NMSU Geothermal well for PG-2, } \\
\text { President's Home }\end{array}$
\end{tabular}

NMSU \#1 $385^{\prime} \quad 3900^{\circ} \quad 400-\quad 6150$

Secondary producer of campus domestic weter

NMSU \#2 $485^{\circ} \quad 3903^{\circ} \quad 6000$

This well is used only for an observation well

\begin{tabular}{|c|c|c|c|c|c|}
\hline NMSU $\# 3$ & $678^{\circ}$ & $3985^{\prime}$ & & 3800 & $\begin{array}{l}\text { This well is not used and is question- } \\
\text { able whether it is open at bottom }\end{array}$ \\
\hline NMSU $\# 4$ & $607^{\prime}$ & $4057^{\prime}$ & 1650 & 0 & Golf Course Well \\
\hline NMSU 俳 & $260^{\prime}$ & $3888^{\prime}$ & & 6200 & $\begin{array}{l}\text { Used as an irrigation well, water is } \\
\text { contaminated }\end{array}$ \\
\hline NMSU \#8 & $630^{\prime}$ & $3954^{\circ}$ & $\begin{array}{l}800- \\
900\end{array}$ & 5300 & Not in service at present \\
\hline NMSU \#9 & $525^{\circ}$ & $3932^{\prime}$ & $\begin{array}{l}500- \\
550\end{array}$ & 6400 & $\begin{array}{l}\text { Principal producer for campus } \\
\text { domestic water }\end{array}$ \\
\hline NMSU \#10 & $750^{\prime}$ & 3912 & $\begin{array}{l}400- \\
500\end{array}$ & 7300 & $\begin{array}{l}\text { Principal producer for campus } \\
\text { domestic water }\end{array}$ \\
\hline
\end{tabular}




\section{c. Analysis of possible effects}

From the well logs, driller logs, and analysis of drill cuttings, all of the NMSU geothermal wells have intersected a rhyolite formation. This geological formation consists of weathered to angular rhyolite gravel, interposed with layers of sand and clay. Generally, the formation has become increasingly tight with increasing depth. The entire formation is saturated with water, and the general slope of the formation is a westerly to slightly south-westerly dip of approximately four degrees. This angle of dip is consistent with the well logs for the five wells drilled deeper than 750 feet in an area roughly one-quarter mile long on a north-south axis, and one-half mile on an east-west axis. A recent Las Cruces Test well (located next to IRG 430 on Figure $X-6$ ) intersected this same formation at a depth of approximately 700 feet. All the slim test holes drilled as part of the well completion for the total of six wells showed the same tendency to drift west and south of the true hole center line, consistent with the inferred slope of the rhyolite formation.

These geothermal test wells (and the Las Cruces test well) were logged, and most of the well logs depict a zone of possible lateral flow at a depth of 600 to 700 feet of depth, depending on general elevation at the well head. The presumed direction of lateral flow is east to west, and slightly north to south, consistent with the angle of dip of the rhyolite formation.

From inspection of the well depths listed in Table X-9, the two Las Cruces wells closest to the golf course well are producing from a shallow aquifer 
250 to 350 feet deep. These wells are also located North and East of the golf course well, upstream from the likely water migration in the geothermal field. Hence, it is highly unlikely that use of the golf course we11, with water reinjected at 330 to 600 feet of depth will have any discernable effect on the Las Cruces City Wells.

Considering the NMSU Campus Wells, all three of the currently producing water wells are located more than one mile from the golf course well.

From water chemistry analys is of domestic water wells East and West of I25 highway, the strong possiblity exists that an aquitard underlies the approximate vicinity of I-25. The geothermal wells to the East of I-25 have elevated temperatures $\left(95^{\circ} \mathrm{F}\right.$ to $\left.145^{\circ} \mathrm{F}\right)$, and higher dissolved solids (1450-2000 ppm TDS). On the West side of I-25, the NMSU wells are cold, and have salinity ranging from $370 \mathrm{ppm}$ to $550 \mathrm{ppm}$, with no apparent pattern in this lower salinity value. For example, NMSU \#1, which is 6150 feet due west of the golf course we11, is $450-500 \mathrm{ppm}$, whereas NMSU \#9, located 6400 feet southwest, is in the range of 500-550 ppm. The exact nature of this underground structure is unknown, although data from electrical resistivity and seismic studies tend to confirm the existence of a physical sub-surface structure. This aquitard would tend to limit mixing of the goethermal water with underground Rio Grande River water.

In addition, when well-head elevation and screen setting are taken into consideration, these potable water wells are producing from an aquifer 100 to 300 feet deeper than the reinjection zone at the golf course well. Hence, the long term effects on the NMSU or Las Cruces fresh water wells from reinjection into the Golf Course Well are expected to be minimal. 
Section XI

COST BENEFIT ANALYSIS

\section{General}

In this section, an analysis is presented of the costs and benefits of this geothermal project. The cost determination includes an analysis of the investment costs (installed capital equipment) along with a presentation of likely operating costs. This latter category includes electricity for pumps, depreciation, maintenance and repair, and personnel costs required to service and maintain the installed system. For the benefit portion, an analysis is presented of the cost to produce steam now used, the possible future cost growth, and the potential savings attributable to the geothermal displacement of part of this steam. A more detailed analysis is presented for the domestic hot water system, since that is the primary target. Section XII presents a brief analysis for possible future use of the geothermal water, with research now underway not. expected to provide definitive results until late 1981.

\section{System Investment Cost}

Each of the major system components is discussed in design detail in other sections of this report. In this section, each component is defined in terms of cost, with an allowance for price changes at time of final procurement. Every effort has been made to use written vendor quotations for prices. However, final procurement prices will be set by the competitive bidding process under the State Purchasing Act. In addition, form, fit and functional use during actual construction and installation will reveal hidden costs. For these reasons, the costs presented herein are estimates only. 
A major cost not previously defined is the expended cost attributable to prior research which has paved the way for the current demonstration. This prior research included broad checks for geothermal anomalies conducted under regional studies. Only part of that work can be attributed directly to the MMSU geothermal anomaly. For some research, however, specific work was performed on the NMSU campus. This work included two deep gradient wells (1000 feet and 1200 feet), a cased production test well, electrical resistivity, and gravity and seismic work, and a preliminary engineering feasibility study. For such cases, the entire project, or applicable portions, was attributed to the overall demonstration expended cost.

At Table XI-1 is a summary of the total project costs, along with the source of this funding.

Table XI-1

Total Cost of NMSU Campus Geothermal Project

Fund Source

\section{Category}

Basic Research

Development

Demonstration and
New Mexico

$\$ 30,000$

54,000

125,000

336,000

$1,290,000$

$$
\begin{array}{rr}
\text { plus } & \underline{829,000} \\
\text { TOTALS } & \$ 1,038,000 \\
\text { EXPENDED COSTS } & \$ 741,000 \\
\text { TOTAL NEW COSTS } & \$ 829,000
\end{array}
$$

TOTAL EXPENDED COSTS $\$ 741,000$

Federal (DOE)

Total

$\$ 70,000$

$\$ 100,000$

126,000

180,000

Application$$
\$ 532,000
$$$$
\$ 1,570,000
$$ 
A sumary of remaining capital equipment items is listed in Table XI-2. Each entry in these tables has a supporting exhibit, either included in the appropriate design section of this report, or in the attached tables.

Table XI-2

Installed Capital Equipment Cost Summary

\section{Category}

Pipelines

Gas Separator

Hot Water Storage Tank and Auxiliary Heater

Well Pump and Transmission Power Line

Pump House

Primary Heat Exchanger

Outdoor Pool Heat Exchanger

Equipment Building for Primary Exchanger

Instrumentation and Controls

Building Retrofit

Disposal System and Pumps
Cost

$\$ 350,000$

13,500

$68,800 \quad$ Table XI-4

$50,000 \quad$ Table XI-5

8,600 Table XI-6

$52,300 \quad$ Table XI-7

$6,000 \quad$ Table XI-7

24,000 Table XI-8

$89,000 \quad$ Section IX

$61,800 \quad$ Table XI-9

65,000 Table XI-10
Sub-Total

$\$ 789,000$

Contingency Reserve for Inflation

During 12-month Construction Phase

TOTAL
40,000

$\$ 829,000$ 
Table XI-3

\section{Gas Separator Cost Estimate}

Action

Fabricate Steel Tank

Sandblast and Epoxy Interior

Insulate with 2-inch thickness

of Ureathane Foam

Vapor Barrier \& $\$ 0.50 / \mathrm{ft}^{2}$

Excavation and Burial

Support System

Crane

Equipment Well $10^{\prime} \times 8^{\prime} \times 6^{\prime}$

Sub-Total

Contingency, $10 \%$

TOTAL
Estimated Cost

$\$ 3,200$

800

700

250

1,500

500

350

$\underline{5,000}$

$\$ 12,300$

1,200

$\$ 13,500$ 
Action

Fabricate Steel Tank

Sandblast \& Epoxy $\left(\$ 2.40 / f t^{2}\right)$

Insulation; 2-inch $\left(\$ 1.50 / \mathrm{ft}^{2}\right)$

Vapor Barrier e $\$ 0.50 / \mathrm{ft}^{2}$

Excavation; Burying

Concrete Support Cradles and Piers ( 4 ea.)

Crane

Sub-Total

Contingency, $10 \%$

Sub-Total

Natural gas-fired auxiliary heaters

Extend natural gas line

TOTAL

\section{Estimated Cost}

$\$ 32,000$

6,880

4,300

1,500

2,400

8,880

600

$\$ 56,560$

5,740

$\$ 62,300$

8,000

8,500

$\$ 78,800$ 


\section{Well Pump (PG-3) Specifications and Cost Estimates}

1. Submersible, for hot water with 2,000 ppm TDS.

2. Well characteristics
a. Static level 372 feet
b. Temperature $145^{\circ} \mathrm{F}$
c. Well screen 750 feet
d. Flow rate expected $0-350$ gpm
e. Drawdown level

- at $0 \mathrm{gpm}-372$ feet

- at $350 \mathrm{gpm}-700$ feet

f. Well size: 10-inch ID

g. Screen type: Roscoe-Moss Full-Flo Shutter type

h. Desired characteristics:

350 gpm 700 feet drawdown, with 40 psig back pressure at surface discharge rate of $350 \mathrm{gpm}$

3. Possible source: TRW-REDA

a. Model H350 submersible, 20-stage, with 700 feet of 4.5-inch diameter column. Unit contains a 130 Hp motor.

b. Unit would require 3-phase, 400-480 volt power source, which would be stepped-up through use of an integral $150 \mathrm{KVA}$ transformer to surface voltage of 986 volts.

c. Accessories include the step-up transformer, wire, tubing, well head controls and circuit breaker. 


\section{Table XI-5 (Cont'd.)}

d. Cost: $\$ 35,000$ installed. Lease (rent) purchase agreement if purchased the rental cost applies fully towards purchase. If decision is made to return unit, possible follow-on repair costs to restore the unit to saleable condition will be borne by initial user.

4. Transmission power line extension between NMSU $P G-1$ and $P G-3$; 1200 feet; $\$ 15,000$. 
Table XI-6

Pump House Cost Estimate

Dimensions

Slab $10 ! \times 10^{\prime} \times 6^{\prime}$

Roof $11^{\prime} \times 11^{\prime} \times 6^{\prime}$

2 Walls $10^{\prime} \times 8^{\prime} \times 6^{\prime \prime}$

2 Walls $9^{\prime} \times 8^{\prime} \times 6^{\prime \prime}$

Materials Cost

Concrete:

Estimate $7 \mathrm{yd}^{3}$

Commercial Costs: $\$ 50 / \mathrm{yd}^{3}$

Steel:

Estimate $1,000 \mathrm{ft}$

Commercial Costs: $\$ 3.28 / f t$

Misc. Materials

720

$\$ 4,350$

Materials Costs: $\$ \$ 4,350$

Labor

Forms, steel, and finishing

$\$ 2,500$

Erection labor

$\underline{1,750}$

Labor Sub-total $\$ 4,250$

Total Estimated Cost:

$\$ 8,600$ 
Table XI-7

\section{Primary Heat Exchanger Cost Estimate}

Specifications: Plate-type, counterflow, with $250 \mathrm{gpm}$ hot side at $140^{\circ} \mathrm{F} ; 250 \mathrm{gpm}$ cold side at $65^{\circ} \mathrm{F}$; pressure drop across cold side and hot side not to exceed 15 psig; hot side shall have materials corrosion resistant to geothermal fluid with high chloride content; $10^{\circ} \mathrm{F}$ approach temperature; heat load 13.4 million BTU per hour with 2000 square feet per unit heat transfer area.

Cost Estimate: Based on vendor quotation, cost will be $\$ 41,300$, with probable 10 percent increase since quotation, and 15 per cent installation cost.

$\begin{array}{cr}\text { Unit Cost: } & \$ 41,300 \\ \text { Price Increase: } & 4,200 \\ \text { Installation: } & 6,800 \\ \text { TOTAL } & \$ 52,300\end{array}$


Table XI-8

\section{Equipment Building Cost Estimate}

Dimensions:

Slab $15^{\prime} \times 20^{\prime} \times 8^{\prime \prime}$

Roof $16^{\prime} \times 21^{\prime} \times 6^{\prime \prime}$

2 Walls $15^{\prime} \times 20^{\prime} \times 6^{\prime \prime}$

2 Walls $14^{\prime} \times 19^{\prime} \times 6^{\prime \prime}$

Materials Cost:

Concrete:

Estimate 21.5 cubic yards

Commercial Costs: $\$ 50 / \mathrm{yd}^{3} \quad \$ 1,075$

Steel:

$$
\begin{array}{cr}
\text { Estimate: } & 3,200 \text { feet } \\
\text { Commercial Cost: } \$ 3.28 / \mathrm{ft} & \underline{10,500} \\
\text { Sub-Total } & \$ 11,575 \\
\text { Miscellaneous Materials } & \underline{2,315} \\
\text { Materials Sub-Total: } & \underline{\$ 13,890}
\end{array}
$$

Materials cost $\$ 14,000$ (commercial costs) with amount of materials required, estimate should be lowered by $25-35 \%$ with bulk purchasing. Labor Costs:

Forms, steel forming, finishing: $\quad \$ 5,000$

Labor for erection and weld plates: $\quad \underline{3,500}$

Labor Sub-Total: $\quad \$ 8,500$

Site Preparation and Clean-up: $\$ 1,500$

Total Estimated Cost: $\quad \$ \mathbf{2 3 , 8 9 0}$ 
Table XI-9

Building Retrofit Costs

Pan Am Center

Garcia

WRC

Natatorium

Activity Center

Alumni

Regents

Football Stadium

Rhodes-Garret-Hamiel
$\$ 2,000$

4,025

1,850

6,800

1,475

1,720

15,200

1,800

16,500

$\$ 51,470$

10,294

$\$ 61,764$

These retrofit costs have been estimated by conceptual design of the plumbing system required to interconnect the geothermal system with the existing steam system. They include the price for all of the necessary valving, piping, and insulation, along with the costs of trenching, repaving, and installation labor. The overall picture of the system is a connecting line from the supply line in the utility tunnel to the hot water system of each building, intercepting at the recirculation portion of the particular system, just prior to the heat exchanger inlet. In addition, there will be a small bleed line on the recirculating system to assure continuous flow during nights and cool weather situations, in order to avoid major temperature declines. 


\section{Disposal System Treatment And Storage Costs}

The cost of the domestic water now being used by the golf course is in the range of $\$ 25,000$ per year at $\$ 0.20$ per 1000 gallons (low estimate). If true cost is in the range of $\$ 0.50$ per 1000 gallons, this annual water usage should cost approximately $\$ 62,500$. Two ponds, each one acre in surface area and three feet deep would have to be constructed to use for sedimentation purposes. These ponds would have the capacity for roughly two million gallons, or six days geothermal well supply. Flocculation agents could be added to the water before discharge into the ponds. Use of the flocculation agents would remove approximately 700-800 mg/l of dissolved solids. The concentrations of calcuim, manganese, iron, carbonates $\left(\mathrm{HCO}_{3}\right)$, magnesium, and silicates would be reduced to acceptable levels and the total dissolved solids would be decreased to 1,300 to $1,400 \mathrm{mg} / 1$. This process could result in $35-40$ tons per year of sediment deposited on the bottom of the holding ponds. This would necessitate annual draining and cleaning of the pond. The ponds would be lined with flexible membrane liners used for liquid containment and seepage control. Ponds would be excavated before lining, so as to preclude ground water contamination. Preliminary costs for a variety of treatment and ponding is at Table XI-10. 
Table XI-10

Preliminary Cost Estimates, Water Treatment

Injection Well Pump

Peerless $200 \mathrm{gpm} 50 \mathrm{Hp} \quad$ Cost approximate $\$ 7,000$

Connecting Pipelines

4,000

PVC 20 mil treatment pond liner $20 \% / \mathrm{ft}^{2}$

$$
\begin{array}{ll}
\text { installation } 8-10 \mathrm{f} / \mathrm{ft}^{2} \\
\text { cover } \quad 10-12 \mathrm{c} / \mathrm{ft}^{2}
\end{array}
$$

Installed cost for these ponds would be approximately $\$ 27,000$

Hypolon 36 mil treatment pond liner $52-55 \mathrm{c} / \mathrm{ft}^{2}$

$$
\text { installation } 8-10 \mathrm{c} / \mathrm{ft}^{2}
$$

Installed cost for these ponds would be approximately $\$ 75,000$ Concentrated Sulfuric Acid

$$
\begin{aligned}
& \text { Distributor VNR } \quad \text { Cost } \cong \$ 46 / \text { ton } \\
& \text { Concentration } 95 \%
\end{aligned}
$$

Preliminary analysis indicates the treatment system would require approximately $\$ 35,000$ per year. This, however, might provide water suitable for immediate use.

Dequest 2000 or 2060

$\$ 6,000$ to $\$ 10,000$ per year

Removal of sediments from ponds would require draining the pond, removing sludge, and repairing the liner. Cost estimates based on 40 truckloads per year, at $\$ 150$ cost per truckload, transported to a land fill site. Cost $\$ 6,000$.

\section{Total Cost}

$$
\$ 75,000 \text { to } \$ 133,000
$$




\section{Operating Costs \\ a. General}

Included in this category are the electricity cost of operating the well pumps, the circulating pumps, and electrical controls. This cost is a calculated estimate based on historical data for similar electrical devices. Also included is an allowance for annual maintenance, minor repairs and replacements for valves and controls and expendable supplies used in maintenance. This estimate is based on a general factor expressed as a percentage of investment cost. From other analytical work, this annual cost can range from 1.0 to 2.5 percent of fixed plant investment. A third major factor is a depreciation expense, which for this study is defined as a sinking fund for future replacement, accumulated over the expected lifetime of the component. This cost is a function of the anticipated life of the component, and the yearly amount is the investment cost divided by years of expected life. The fourth major component of operating expense is manpower. Since the installed system will contain three wells, a gas separator complex, a heat exchanger complex, and a hot water storage tank complex, the type and size of equipment involved results in a anticipated need for two full-time maintenance technicians.

\section{b. Electricity Costs}

Based on the current installed and tested well pump, electricity costs are a combination of a demand charge (pegged to installed kilowatt load), a monthly service charge, and an hourly consumption charge determined by operating electrical load, time of operation, at a fixed charge per kilowatt hour of consumption. For the first well pump, assuming 24-hour 
per day operation for a full year, these aggregate costs would be $\$ 8820$ per year. In turn, this is an average cost of $\$ 0.0567$ per kilowatt hour of electricity consumed.

For the second well, with a larger pump and bigger net head requirement, the charge would be in the range $\$ 13,000$ a month if the demand charge of $\$ 6.45$ per installed kilowatt is applied. Consideration is being given to a university funded power line, however, which could eliminate this demand charge. Under that circumstance, the yearly cost would decrease to $\$ 6200$

Since only one of the wells will operate at any one time, the annual cost will be an average cost between the two pumps. For purposes of cost estimating, the current (or historical) value of $\$ 8800$ is used.

In aggregate, a total of 56 horsepower in other circulation pumps will be installed. These pumps will operate almost constantly, and will have an operating load of 20 kilowatts. Using the same kilowatt per hour cost now charged for the first well pump as the cost, provides a cost estimate of $\$ 9800$ per year. Since this cost includes a demand charge, a lower cost is probable considering only the kilowatt hour cost now used, or $\$ 6300$ per year. For purposes of this analysis, the lower value is used. Thus, total expected electricity cost based on 1980 costs, is $\$ 15,100$ per year.

\section{c. Maintenance Costs}

The following table reflects the installed costs of system components for which a reasonable expectation exists for minor maintenance. 
Table XI-11

\section{Projected Maintenance Significant Components}

Component

Primary Heat Exchanger

Pool Heat Exchanger

Well Pumps
Purchase Price

$\$ 45,000$

6,000

60,000

50,000

10

and Circulating Pumps

Hot Water Storage Tank

Transmission Line Components

TOTAL

Instrumentation and Controls

\section{Life (years)}

10

5 years; then

overhaul at $30 \%$ of cost for second five years

Annual Maintenance Expense @ 2.5\% $=\$ 6,300$

d. Equipment Depreciation (Sinking Fund)

From Table XI-11 the lifetime in years of key components can be determined. Not included are the wells, which should have more than a 20-year expected life. Also excluded are the gas separator tank and the water transmission line pipeline, as these components also should last more than 20 years. Given these assumptions, an annual depreciation cost can be estimated. Results are listed in Table XI-12. 
Table XI-12

\section{Projected Depreciation Costs for Significant Components}

\section{Component}

Heat Exchangers

Pumps

Instrumentation and Controls

Hot Water Storage Tank

Transmission Line Components

TOTAL
Annual Depreciation

$$
\$ 5,100
$$

7,800

5,000

3,000

5,000

$\$ 25,900$

\section{e. Manpower Costs}

Based on the assumption that two full-time technicians are required, an annual cost can be calculated. A Grade B Mechanical Technician, with two to three years experience will be qualified to maintain the system. This Grade B technician is paid an hourly rate on the average of $\$ 6.43$ for three years experience, up to $\$ 10.28$ per hour for more than 20 years experience. An hourly rate of $\$ 7.00$ is assumed. On an annual basis of 2080 working hours, with 15.13 percent for fringe benefits, this annual salary would be $\$ 16,750$. With two technicians required, total annual salary cost is $\$ 33,500$. 
f. Summary of Operating Costs

Table XI-13 is a summary of projected annual operating costs. The total of $\$ 80,800$ includes the sinking fund set-aside of $\$ 25,900$. In perspective, the total represents 9.75 percent of the $\$ 829,000$ new investment cost, which is an unusually large allowance toward annual operating costs. A percentage quite commonly used is to assign estimated operating costs as 5 percent of investment costs. Because this demonstration project involves many unknowns, it is believed that the higher percentage is a more realistic assessment.

Table XI-13

Projected Annual Operating Expenses

Category

Electricity

Maintenance

Depreciation

Technician Labor
Annual Cost

$\$ 15,100$

6,300

25,900

33,500

TOTAL 


\section{Cost Growth Factors}

a. General

Each of the major components of operating cost, except the fixed annual sinking fund charge, is subject to future cost growth. Similarly, the steam cost is likely to increase in the future. As to what this cost growth might be can best be categorized as informed speculation. However, in the absence of any other information, use can be made of future years price growth based on national level indices. Such price growth normally is treated as two separate, but to a degree interacting, phenomena. First, increasing scarcity or other factors internal to the commodity normally are considered to result in a real price growth rate. Secondly, the overall economic inflation rate can cause absolute price increases, but all goods and commodities can be assumed to increase at a common rate so that there are no price differentials created.

\section{b. Real Price Growth Rates}

The U.S. Department of Energy, Energy Injormation Agency (DOE/EIA) publishes annual estimates of energy prices and availability. A comprehensive report was released in April 1979, "Energy Supply and Demand in the Midterm: 1985, 1990, and 1995". The report contained a number of possible energy price growth scenarios, keyed to changes in world markets and fuel sources. Of this possible range of scenarios, the median case was chosen for illustration in our report. MMSU is a large, bulk consumer of natural gas, and the price charged per mcf is at the bottom of a declining block rate schedule. This situation is typical of a large industrial user; hence the industrial segment of the median case was used. Under this scenario, natural gas will show an 8.5 
percent real price growth per year through 1990, and 6 percent thereafter. In subsequent reports by the DOE/EIA, other scenarios have assumed availability of gas from new well drilling programs, with large amounts available in the mid-1980's. Accordingly, the authors of this report assumed that real price growth rate would be 8.5 percent per year through 1985, and with partial deregulation in that year, real price growth rate would cease.

The above assumption is consistent with an October 1980 DOE/EIA publication (DOE/EIA-0173(79)/3(SYN) from which the following information was extracted:

TABLE XI-14

Mid Case Projections for Industrial Use Natural Gas Prices (Constant 1979 Dollars)

$1965 \quad \frac{\text { History }}{1973} \quad 1978 \quad 1985 \frac{\text { Projections }}{1990}$
1995

$\begin{array}{lllllll}\begin{array}{c}\text { Supply Price } \\ \text { \$/MMBTU }\end{array} & 0.35 & 0.34 & 2.19 & 2.68 & 3.68 & 4.04 \\ \begin{array}{c}\text { Demand Price } \\ \text { \$/MMBTU }\end{array} & 0.76 & 0.75 & 1.56 & 3.47 & 4.85 & 5.40\end{array}$

The supply price is the average domestic well head price. Demand price is the price paid by large users, which includes distribution costs in addition to acquisition costs. To attain real price listed above, industrial natural gas prices will increase at 8.5 percent per year through 1988, and 2.0 percent per year thereafter. Because of the many uncertainties involving future year supply and availability, the authors of this NMSU report chose to use a lower real price growth rate. If prices actually increase faster, savings from the geothermal system will increase proportionally. 
For other goods and services, the assumption made is that these goods would increase in price at the same real annual growth rate as the Gross National Product. From the October, 1980 DOE/EIA report, this growth would be in the range of 2.5 percent per year.

For purposes of this analysis, the fuel cost increase is analyzed using three different scenarios; namely an NMSU "historic" rate of 33 percent per year, and two different real price growth rates. The first is the modified DOE/EIA projection previously defined. The second rate assumes that the Las Cruces area is sheltered somewhat from national factors.

This lower rate ( 4.5 percent per year real price growth rate through 1985, and zero growth thereafter) is assumed based on Las Cruces historial natural gas prices. During the $1960^{\prime} \mathrm{s}$ and $1970^{\prime} \mathrm{s}$, interstate gas was much less expensive than intrastate, so efforts were made to maximize the purchase of interstate gas. In the period 1975-1980, Las Cruces supplemented the fixed allotment interstate gas, with more costly intrastate gas. Approximately, 80-85 percent was interstate, with the balance intrastate. Increase in interstate gas prices acted to change that balance as illustrated in the following table. Note that the price listed is the price paid by the City of Las Cruces. Users must pay the acquisition cost plus city distribution and administrative costs, which are approximately $\$ 1.00$ per mcf,

TABLE XI-15

Natural Gas Purchase Price, Las Cruces

(\$/mcf)

Interstate

Intrastate $\frac{1977}{1.40}$

1.95 $\frac{1979}{1.90}$

2.21 $\frac{1980}{2.27}$

2.25
1981

2.62

Not used at present 
This tabular data suggests that for interstate gas, Las Cruces had combined real price and inflation price growth rate of 19 percent from 1979 to 1980 , and 15 percent from 1980 to 1981 (thus far). This combined rate is less than the 8.5 percent real price growth, and 12 to 14 percent inflation rate being experienced nationwide. This favorable trend might not continue; but a price growth rate lower than the national average is possible. Accordingly, to establish a lower boundary for possible price growth, the assumption was made that Las Cruces could experience only 4.5 percent real price growth through 1985.

\section{c. Inflation Rates}

Economic inflation has been escalating at more than a double-digit rate for the past several years, and there is little reason to expect 1981 to show a marked decrease. However, the long-term trend is expected (or hoped) to reduce as a result of new fiscal and monetary policies being placed into effect. For purposes of this report, arbitrary assumptions are made that the economic inflation rate will be 12 percent in 1981 , will be reduced to 8 percent per year in 1982 and 1983 , and be further reduced to the long term average of the decade of the 60 's, or a rate of 5 percent per year thereafter. It is necessary to make some such assumptions, because the overall pay-off period of the investment must consider the effects of this inflation rate. If no inflation is assumed, the cost analyst can overlook real cost problems in future years for system maintenance. It is believed to be far more misleading to assume an inflation rate as high as the past several years, because this could result in over-optimism in terms of early pay back of investment. The stated assumption attempts to steer a middle course between these two extremes. 
Table XI-16 is a summary of those price growth scenarios, depicting the several different assumptions made for inflation rate, and for real price growth rates, In turn, Table XI-17 illustrates the compounding effects as an index for each year, of the resulting price escalations.

Table XI-16

Possible Price Growth Scenarios

Component

Case 非 $197 \overline{9-80 \text { cost }}$ of $33 \%$, compounded through 1991.

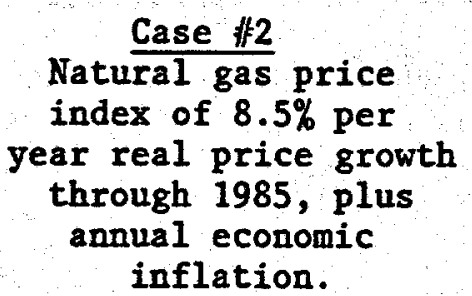
inflation.

\author{
Case $\{3$ \\ Operating cost \\ price index of \\ $4.5 \%$ per year \\ real price growth \\ through 1985, plus \\ annual economic \\ inflation.
}
Inflation Rate
$12 \%$ per year, 1981
$8 \%$ per year, 1982 and 1983
$5 \%$ per year, $1984-1991$

Other Goods Real Price Growth

$2.5 \%$ per year through 1985 ; thereafter constant

Table XI -17

Compounded Price Growth Indices

\begin{tabular}{|c|c|c|c|c|c|c|c|c|c|c|c|}
\hline$\frac{\text { Steam Cost }}{\text { Case } \mathbb{\# 1}}$ & $\frac{81}{1.33}$ & $\frac{82}{1.77}$ & $\frac{83}{2.35}$ & $\frac{84}{3.18}$ & $\frac{85}{4.22}$ & $\frac{86}{5.62}$ & $\frac{87}{7.47}$ & $\frac{88}{9.34}$ & $\frac{89}{13.22}$ & $\frac{90}{17.58}$ & $\frac{91}{23.38}$ \\
\hline $\begin{array}{l}\text { Case 非 } \\
\text { Inflation } \\
\text { Real Growth } \\
\text { Composite }\end{array}$ & $\begin{array}{l}1.12 \\
1.085 \\
1.2152\end{array}$ & $\begin{array}{l}1.08 \\
1.085 \\
1.424\end{array}$ & $\begin{array}{l}1.08 \\
1.085 \\
1.668\end{array}$ & $\begin{array}{l}1.05 \\
1.085 \\
1.901\end{array}$ & $\begin{array}{l}1.05 \\
1.085 \\
2.166\end{array}$ & $\begin{array}{l}1.05 \\
1.0 \\
2.274\end{array}$ & $\begin{array}{l}1.05 \\
1.0 \\
2.388\end{array}$ & $\begin{array}{l}1.05 \\
1.0 \\
2.51\end{array}$ & $\begin{array}{l}1.05 \\
1.0 \\
2.63\end{array}$ & $\begin{array}{l}1.05 \\
1.0 \\
2.76\end{array}$ & $\begin{array}{l}1.05 \\
1.0 \\
2.9\end{array}$ \\
\hline $\begin{array}{l}\text { Case } \mathbb{F} \\
\text { Inflation } \\
\text { Real Growth } \\
\text { Composite }\end{array}$ & $\begin{array}{l}1.12 \\
1.045 \\
1.17\end{array}$ & $\begin{array}{l}1.08 \\
1.045 \\
1.32\end{array}$ & $\begin{array}{l}1.08 \\
1.045 \\
1.49\end{array}$ & $\begin{array}{l}1.05 \\
1.045 \\
1.636\end{array}$ & $\begin{array}{l}1.05 \\
1.045 \\
1.795\end{array}$ & $\begin{array}{l}1.05 \\
1.0 \\
1.88\end{array}$ & $\begin{array}{l}1.05 \\
1.0 \\
1.98\end{array}$ & $\begin{array}{l}1.05 \\
1.0 \\
2.077\end{array}$ & $\begin{array}{l}1.05 \\
1.0 \\
2.18\end{array}$ & $\begin{array}{l}1.05 \\
1.0 \\
2.29\end{array}$ & $\begin{array}{l}1.05 \\
1.0 \\
2.41\end{array}$ \\
\hline $\begin{array}{l}\text { Operating Co } \\
\text { Inflation } \\
\text { Real Growth } \\
\text { Composite }\end{array}$ & $\begin{array}{l}1.12 \\
1.025 \\
1.148\end{array}$ & $\begin{array}{l}1.08 \\
1.025 \\
1.271\end{array}$ & $\begin{array}{l}1.08 \\
1.025 \\
1.41\end{array}$ & $\begin{array}{l}1.05 \\
1.025 \\
1.51\end{array}$ & $\begin{array}{l}1.05 \\
1.025 \\
1.63\end{array}$ & $\begin{array}{l}1.05 \\
1.0 \\
1.71\end{array}$ & $\begin{array}{l}1.05 \\
1.0 \\
1.79\end{array}$ & $\begin{array}{l}1.05 \\
1.0 \\
1.88\end{array}$ & $\begin{array}{l}1.05 \\
1.0 \\
1.98\end{array}$ & $\begin{array}{l}1.05 \\
1.0 \\
2.08\end{array}$ & $\begin{array}{l}1.05 \\
1.0 \\
2.18\end{array}$ \\
\hline
\end{tabular}


d. Steam Cost Growth Rate

At Figure XI-l is a chart of the rapidly escalating cost to produce steam on the NMSU Campus. As can be seen, the cost per 1000 pounds of steam has increased from $\$ 0.88$ in 1973 , to the 1980 cost of $\$ 4.27$. Most of this price hike has been in the natural gas segment, and in 1980 this cost was $\$ 3.54$ per 1000 pounds of steam. The remainder of the steam cost consists of electricity for pumps, make-up water, and water treatment, and minor maintenance and repairs. 


\author{
NMSU CAMPUS \\ COST TO PRODUCE STEAM \\ FY 1973-1980
}

:

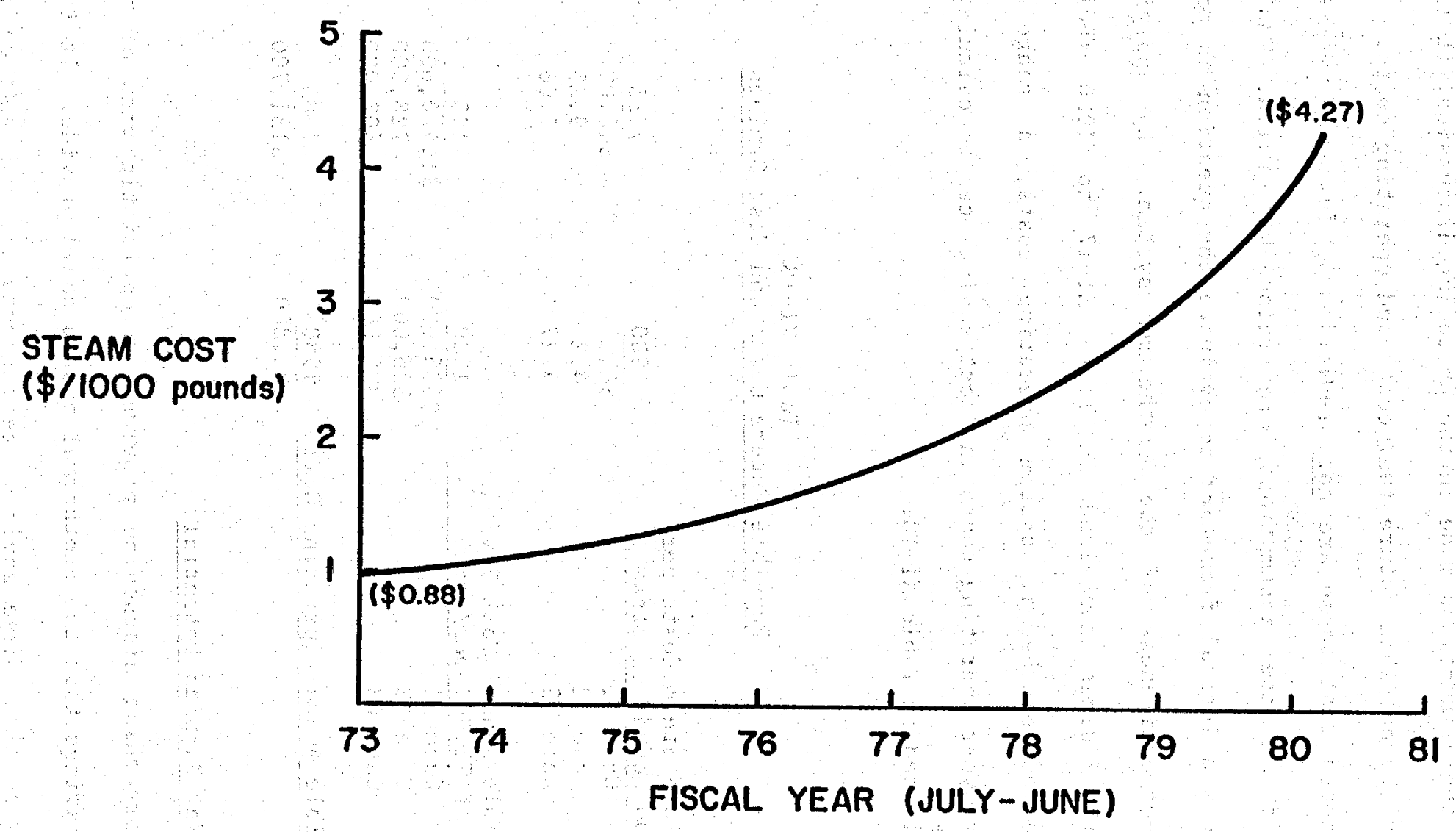

F1gure XI-1 
e. Discussion of Possible Future Costs and Cost Savings

With the assumptions made in the preceding discussion, it is possible to calculate possible future fuel costs and operating costs. The reader is cautioned that these are not predictions. Instead, these are possible prices if the assumptions are reasonably valid. As such, they present a logical framework to evaluate the question as to the overall cost-effectiveness of the geothermal system. By applying the cost growth indices contained in Table XI-17 to 1980 fuel costs and projected geothermal system operating costs, a range of possible future year operating costs and cost savings can be calculated. Results are listed in Table XI-18:

Table XI-18

Possible Future Costs and Cost Savings

Possible Steam Costs per

\begin{tabular}{c}
1000 pounds of steam \\
\hline Case $\# 1$ \\
Case $\# 2$ \\
Case \#3
\end{tabular}

$\$ \frac{1980}{4.27}$

4.27

4.27

Possible Annual Cost Savings,

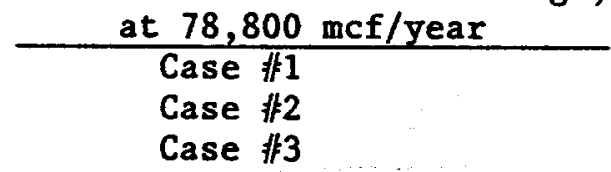

$$
\begin{array}{r}
\$ 3 \frac{1980}{36,000} \\
336,000 \\
336,000
\end{array}
$$

Possible Annual Operating Costs

$$
\$ \frac{1980}{\$ 80,800}
$$

$\$ \frac{1991}{99.84}$

10.29
9.25

7.66

1985

$\$ 1, \overline{420,000}$

728,900

603,000

1985

$\$ \frac{1985}{131,700}$
$\$ 7, \frac{1991}{867,000}$
979,000
810,800

1991

\section{Net Surplus Potential}

The preceding discussion provides an optimistic view of the potential net savings that the geothermal system could provide. It is emphasized, however, that these savings are conjectural, and must be demonstrated. Moreover, these savings are based on the implicit assumption that the investment costs are from appropriated dollars which will not be repaid 
directly, or at most would be repaid through future year decreases in monies appropriated for utility bills. At any event, there is no monthly or annual interest cost on the investment. Accordingly, the NMSU system, although very cost-beneficial, is in a different category than would be a system which required loan amortization and interest payments. With these constraints, and consistent with the assumptions previously made, the potential net fund surplus which the geothermal system possible can provide is depicted in Table XI-19. This surplus could be considered as an offset to other utility costs, for example, electricity for the NMSU campus which requires more than $\$ 900,000$ per year. Conversely, the sinking fund could be used to accumulate resources for future expansion of the system after the initial demonstration has proved itself. In any event, these possible savings must first materialize before any use is made of them.

Table XI-19 compares only the possible price growth from Case 非 and Case \#3. Case \#1 is excluded, because such a price growth rate (a 25-fold increase in ten years) is very remote. In perspective, if energy costs grew this fast, it would be unlikely that the institution would remain open. Hence, Case \#1 is of interest only from an academic perspective, and is not considered further.

Table XI-19

Possible Net Annual Surplus

(After system construction) (Thousands of Dollars)

Case $\$ 2$

Steam Cost $\frac{82}{491}$

Operating Cost 103

Net Savings 388

Case 非

Steam Cost $\$ \frac{82}{455}$

Operating Cost 103

Net Savings 352 $\frac{83}{\$ 576}$

$114 \quad 122$.

$462 \quad 534$

$\frac{83}{\$ 514}$

114

400

$\frac{84}{\$ 564}$

122

442 $\frac{84}{\$ 656}$

$\frac{85}{\$ 747}$

$\frac{86}{\$ 784}$

132

615 $\frac{85}{\$ 619}$

132

487
676

$\frac{87}{\$ 824}$
144
680

$\$ \frac{88}{\$ 866}$

152

714

$\frac{89}{\$ 910}$

160
750

$\frac{90}{\$ 955} \$ 1, \frac{91}{006}$

$\frac{87}{\$ 683}$

144

539 $\frac{88}{\$ 717}$

152

565
$\$ \frac{89}{\$ 752}$

160

592

$168 \quad 176$

$787 \quad 830$

$\frac{90}{\$ 790} \quad \frac{91}{831}$

$168 \quad 176$

622665 


\section{Pay-off Period}

a. General

Conventionally, the payoff or cost break-even period is one of the more significant measures of the overall worth of a project. This demonstration project as funded is financed within a system not available to the private sector. Hence, the payoff period as calculated is not done with the normally accepted discounted cash-flow system. Instead, calculations are based on total taxpayer investments compared with the possible net annual surplus as defined previously. One possibly can argue that research costs should be excluded, because the return on that cost is an increase in the information pool. Because there are several different ways to look at such costs, the payoff period also is calculated using the expended investment cost basis, including research, previously defined. For each investment cost, however, the payoff period is calculated by dividing the summation of investment costs by the summation of net potential surplus.

b. Payoff Period, Varying Investment Categories

From Table XI-1, the investment has been categorized by fund source and program application. Using these categories as a basis the following table reflects the possible payoff period. 
Table XI-20

$\frac{\text { Possible Payoff Period }}{\text { (Years of Operation) }}$

Cost Basis

$\begin{array}{lccc}\begin{array}{c}\text { Category of Investment } \\ \text { Total Investment } \\ (\$ 1,570,000)\end{array} & \frac{1980 \text { Costs }}{6.1} & \frac{\text { Case } \# 3 \text { Costs }}{4.8} & \frac{\text { Case } \# 2 \text { Costs }}{3.3} \\ \begin{array}{c}\text { Committed Funds } \\ (\$ 1,270,000)\end{array} & 5.0 & 3.1 & 2.8 \\ \text { Total New Mexico Funds } & & & \\ \quad(\$ 1,038,000) & 4.1 & 2.4 & 2.4 \\ \text { New Appropriation } & & & \\ \quad(\$ 829,000) & 3.2 & 2.2 & 1.9\end{array}$

\section{Other Benefits}

One of the more significant, but intangible, benefits to a sucessful geothermal demonstration is the impetus this can provide to other applications. In assessing possible new applications, the greenhouse and food processing industries are the most likely targets, because the heat energy needs of these firms match the abundant low-to-moderate geothermal resouces. In addition, both industries are labor intensive and agrarian based, which would fit with the prevailing New Mexico labor market. Moreover, the moderate climate and long growing seasons should facilitate a lower food stock unit cost. At the same time, the moderate climate is a causitive factor in the sun-belt migration, and an expanding market could help in the relocation of such firms to this area. In fact, the successful well-testing program already has spurred a significant level of interest in the southern New Mexico area, with its geothermal potential. Other sections of the Rio Grande rift, which contains the majority of New Mexico's population, also are likely to benefit. 
In terms of natural gas displacement, conserving supplies of natural gas should help preserve these stocks for users who have no near-term alternative. Residential users, large industries, and the eastern U.S. will need natural gas for the indefinite future. It can be argued that preserving New Mexico natural gas for future sale in the interstate market is a more cost-effective solution than burning this gas today.

Moreover, although the current national perspective apparently is a belief that expanded drilling operations resulting from decontrol will result in increases in the proved reserves of natural gas, New Mexico proved reserves still are on a down trend. Hence, these supplies should be conserved for future use if at all possible for those consuming sectors which require natural gas.

Also of direct benefit will be the reduction in air pollution based on the displacement of natural gas. Since the Las Cruces area suffers from below standard air quality during the winter season, a reduction in air pollution is a positive benefit.

Based on standard EPA emission factors for moderate size industrial boilers without emission control (Perkins, 1974) displacement of natural gas could result in reductions in air pollution as shown in the following table.

Table XI-21

Air Pollution Reductions (pounds/year)

$\begin{array}{lccc} & \frac{\mathrm{NO}_{2}}{12-\text { building system }} & \frac{\mathrm{SO}_{2}}{32} & \frac{\text { Particulates }}{(78,800 \mathrm{mcf})} \\ \begin{array}{c}\text { Full system } \\ (170,000 \text { mcf })\end{array} & 17,000 & 1400 & 3000\end{array}$


Figure XI-2 depicts the overall natural gas consumption for the NMSU steam plant, and those portions which can be displaced by the 12-building geothermal system. 


\section{NMSU CENTRAL PLANT GAS CONSUMPTION 1979-1980 \\ VS \\ ESTIMATED POTENTIAL GEOTHERMAL OFFSETS}

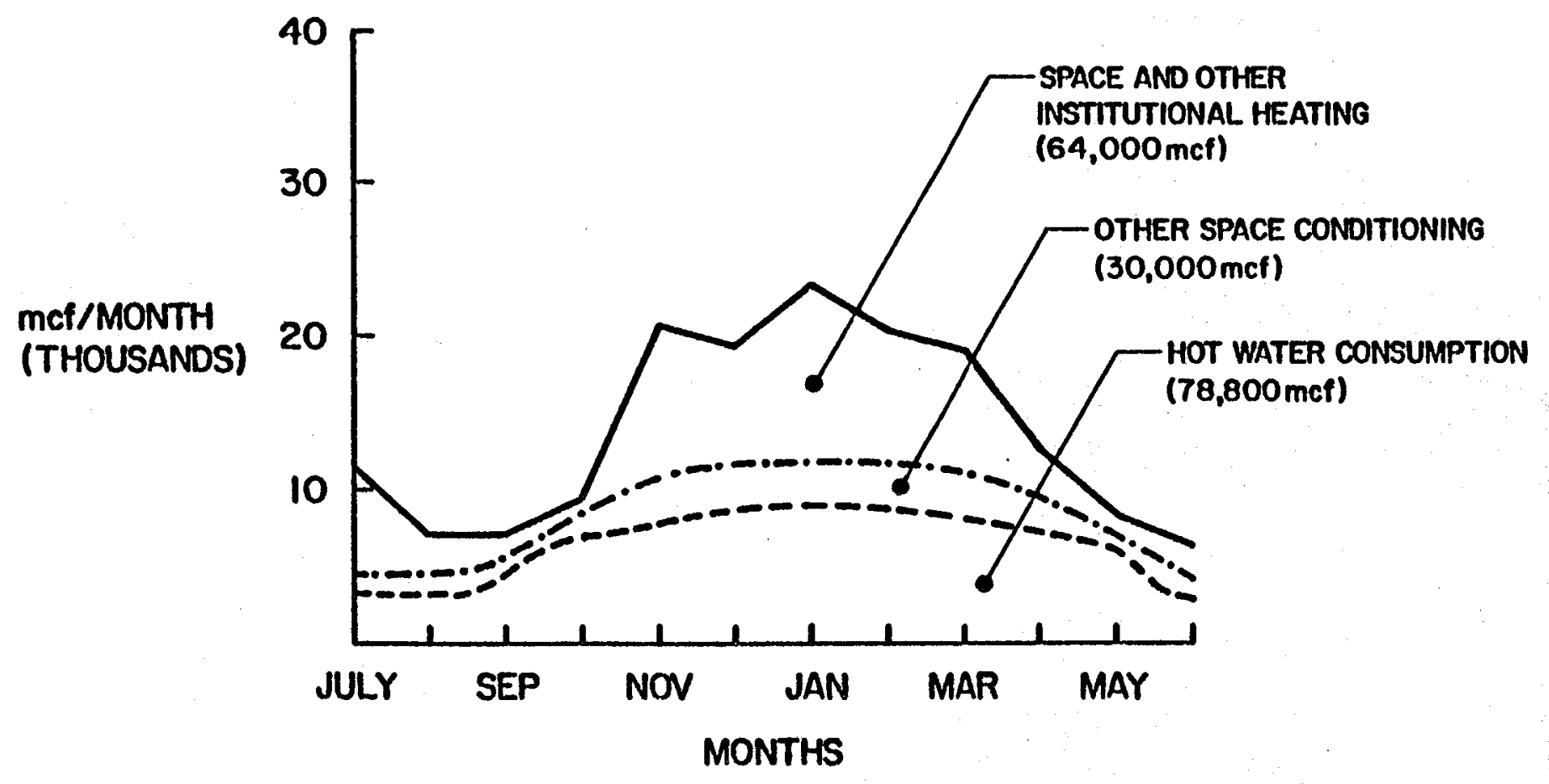

Figure XI-2 


\section{FUTURE EXPANSION}

\section{Non-Heating Season Use of Steam}

As defined earlier in this report, the current geothermal system is designed to displace only domestic hot water consumption in twelve target buildings. However, sixteen other buildings use small amounts of domestic hot water. In addition, six buildings use steem or steam-heated hot water for institutional purposes.

\section{Heating Season Use of Steam}

In reviewing possible routes for a geothermally-heated line, some buildings are so remote from existing utility tunnels that it is not practical to consider the geothermal option. For these buildings now using steam, 5 are connected with burled piping, and a total of 45 buildings are colocated with the existing utility tunnel system. of these 45 buildings, five use a live-steam heating system, four are provided service from another bullding, two use an alternative energy system. The remaining 34 buildings are possible candidates for a future geothermal heating option.

\section{Discussion of Alternatives}

The easiest, and perhaps least expensive option for those smaller uses in 16 buildings now being provided domestic hot water service is through use of a small electric hot water heater. Nine other buildings now use this option. A first approximation is that the total installed cost of sixteen electric hot water heaters would be roughly fifty percent of the single year steam cost now being used. A total economic analysis would 
be necessary, which would address electricity costs, maintenance and replacement costs, and related operating expenses. This analys is will be completed during the construction phase of the 12-building system. Future natural gas price increases especially after deregulation, could make this option a necessity, especially for the seven-month non-space heating season.

In order to facilitate a seasonal shut down of the Central Steam Plant, it would be necessary to replace the steam requirements of specific builidngs dependent on campus steamlines for year-round unit operation with alternative modes of steam/hot water generation. From data acquired relative to total steam consumption, and analysis of that portion of the steam now used for hot water, a clear picture has emerged. During the non-heating season from 15 April through 15 November (seven months), a yearly average of 125,000 mcf of natural gas are consumed. Some 78,000 mcf are used in the twelve target geothermal buildings. Hence, those other non-heating season users are consuming 47,000 mcf per year. In 1980 costs, this consumption represents $\$ 200,000$ per year. The buildings requiring equipment changes and the equipment requiring replacement are depicted in Section II, Tables II-4, II-5, and II-6; a short discussion of replacement cost factors is in the following paragraphs.

The stills and autoclaves listed in the Biology and Agricultural buildings can be replaced by electric models similar to those currently used in Jett Hall and the Physics Department. These replacement stills and autoclaves will not be inferior in performance to those already in use sut would 
in fact be more reliable and efficient than the equipment presently being used. Increased efficiency is the basis for replacing the two dishwashers in the Biology buildings. As an alternative for the steam stills, the academic departments could consider small electric reverse osmosis stills as is done by the Civil Engineering Department and Chemistry building.

Corbett Center operation presents a complex situation in that many alternatives exist for the replacement of the hot water/steam equipment needed by the kitchens. Replacement of the dishwasher currently powered by the campus steam line can be accomplished by an equivalent electric dishwasher at a substantial cost. Another alternative would be to switch the dishwasher from steam to electric. This would require less expense than outright replacement but would necessitate considerable downtime. A commercial hot water heater would be needed to supply the cooling water needed by the epicurean kitchen. It also would be practical to place a natural gas boiler in the equipment room in Corbett Center. This boiler would generate the steam to run all the existing equipment.

The Meat Laboratory would need an electric or gas commercial hot water heater to replace the steam-driven heat exchanger currently used. A commercial heater would be at least as efficient as the current heat exchanger in use.

Inherent in the retrofit possibllities of each building is cost. However, much of the equipment discussed thet would require replacement is quite old and in the near future will require routine replacement. 
Replacing old steam-driven units with more efficient equipment would benefit campus users and would give the university administration the capability to save overall natural gas costs by a seasonal shut down of the Central Heating Plant.

As was indicated at the outset, this non-heating use of steam costs at least $\$ 200,000$ per year in 1980 costs. If the steam plant were operated solely for the uses outlined ebove (after hot water service is displaced by geothermal) the overall system efficiency would diminish, and the total cost of providing the service would increase. In turn, with escalating energy costs acting to drive steam costs upwards, an economic imperative will exist to convert all these users to a non-natural gas energy form.

\section{Geothermal Space Heating}

An analysis of natural gas consumption data provided in Section II indicates that approximately 30,000 to 70,000 mcf per year of natural gas are consumed for space heating needs during the five-month heating season, with most of this consumption in the period late-November through early March. As can be seen by Table XIII-1, an aggregate peak flow of almost $6,700 \mathrm{gpm}$ of water heated by steam heat exchangers is used in spaceheating these buildings. Almost all of these systems were inspected, and the circulating hot water system ranged in temperature from $90^{\circ} \mathrm{F}$ to $160^{\circ} \mathrm{F}$. Thus, a preliminary conclusion is that the geothermal water at a delivered temperature of $125^{\circ} \mathrm{F}$ could satisfy the total heating load for many of the buildings, and at least half of the load for other buildings. With an increased flow rate at the delivered temperature, the entire system could be satisfied. The single imperative is, then, sufficient flow of geothermal water to satisfy this circulating hot water need. 
In order to provide a point of departure, a working assumption is that the ratio to peak and average water flow rates derived for the domestic hot water system applies to the heating systems (a ratio of peak to average flow of 2.2). If this is true, the average flow rate would be in the range of $3,000 \mathrm{gpm}$. As that flow rate, a well field of ten wells would be required to satisfy average demand, and these wells would be used less than ten percent of the time. This approach inherently is not costeffective. Hence, a combination of design approaches is necessary, and the most viable design would appear to be one in which the geothermal heating system provides off-peak heat only, with a small standby boiler system used only for the coldest days of the year to peak the system.

Another approach is to select these building targets which could be accommodated with the facilities installed for domestic hot water. The following table illustrates the likely candidates. 
Table XII-1

Future Expansion Options

\section{Option Building}

\#1 Breland Hal1

$\begin{array}{lr}\text { Regents Row } & 90 \\ \text { Women's Residence Center } & 210\end{array}$

\#2 Breland Ha11 Rhodes-Garrett-Hamiel $\quad 112$

Garcia Dorms $\quad 240$

Alumi Dorms $\quad 160$

Activity Center $\quad 330$

Natatorium $\quad 100$

O'Donnel1 112

PSL

\#3 Remaining Buildings
Peak flow Est. Avg. gpm

120 $\frac{200}{1,554}$

706
Flow (gpm) Source of Hot Water

54 Waste water from exit of outdoor pool heat exchanger. Exit temperature $105^{\circ} \mathrm{F}$, and average flow 80-100 gpm. Located across street from outdoor pool.

(as above)

Expand well pumping to

theoretical maximum rate with two wells, add a third well as backup, add two additional heat exchangers, and a second hot water storage tank, and retrofit costs. Alternatives must be given cost trade-offs. System would use heated water to heat the buildings with a $10-15^{\circ} \mathrm{F}$ temperature drop, and then use the remaining heat for domestic hot water.

Would necessitate exploratory actions to find a deeper, hotter geothermal resource, or closer to campus, or both; in combination with a peaking system. 
5. Because a definitive engineering cost analys is has not been made, it is possible only to make some generalized comments concerning cost and benefits. The following table relects the summary conclusion of the design team based on similar system used elsewhere.

Table XII-2

Future Expansion Cost and Benefits

$\begin{array}{lll}\text { Option } & \text { Cost } & \text { Benefits } \\ \# 1 & \$ 15,000 & 2-3 \text { year pay off at } 1980 \text { costs; save } 275 \mathrm{mcf} / \text { year } \\ \# 2 & \$ 450,000 & 5-7 \text { year pay off at } 1980 \text { costs; save } 15,000 \mathrm{mcf} / \text { year } \\ \# 3 & \$ 1.5 \text { million } \$ 200,000 \text { per year at } 1980 \text { costs; save } 50,000 \mathrm{mcf} / \text { year }\end{array}$


Tabie $\times 11-3$

Summary of Steam Usage. MMSU Central Plant System

\begin{tabular}{|c|c|c|c|c|c|}
\hline Bullaing & Heating Svstem & $\begin{array}{l}\text { Heating system } \\
\text { HW Flow Rate }\end{array}$ & $\begin{array}{l}\text { Hot Water } \\
\text { Generator }\end{array}$ & $\begin{array}{l}\text { No. of Hot } \\
\text { Water Faucets }\end{array}$ & $\begin{array}{l}\text { DHW } \\
\text { Temp }\end{array}$ \\
\hline Agriculture & Steam & $400 \mathrm{GPM}$ & Steam & 98 & $104^{\circ}$ \\
\hline Blology & Steam & $240 \mathrm{GPM}$ & Steam & 64 & $136^{\circ}$ \\
\hline Chemistry & Steam & $240 \mathrm{GPM}$ & Steam & 17 & $131^{\circ}$ \\
\hline Jett & $\begin{array}{l}\text { Double Duct } \\
\text { Steam }\end{array}$ & $240 \mathrm{GPM}$ & Steam & 30 & $150^{\circ}$ \\
\hline Physics & Steam/Hot Wtr. & $400 \mathrm{GPM}$ & Steam & 45 & $131^{\circ}$ \\
\hline Goddard & Steam & 88PGM & Steam & 12 & -- \\
\hline Thomas Brown & $\begin{array}{l}\text { Double Duct } \\
\text { Steam }\end{array}$ & Live Steam Coll & Steam & 23 & $60^{\circ}$ \\
\hline o'Donnel I & Steam & $112 \mathrm{GPM}$ & Steam & 14 & $108^{\circ}$ \\
\hline Kegents Row & Steam & $90 \mathrm{GPM}$ & Steam & 204 & $145^{\circ}$ \\
\hline $\begin{array}{l}\text { Footba I I } \\
\text { Stadium }\end{array}$ & Steam & $112 \mathrm{GPM}$ & Steam & 68 & $130^{\circ}$ \\
\hline $\begin{array}{l}\text { Natatorium } \\
\text { Outdoor Pool }\end{array}$ & Steam & $200 \mathrm{GPM}$ & Stean & 12 & $120^{\circ}$ \\
\hline Alumnl Dorms & Stear: & $160 \mathrm{GPM}$ & Steam & 467 & $131^{\circ}$ \\
\hline Pan Am & Steam & $400 \mathrm{GPM}$ & Steam & 25 & $135^{\circ}$ \\
\hline Meat Lab & Steam & $88 \mathrm{GPM}$ & Steam & 6 & $130^{\circ}$ \\
\hline
\end{tabular}


Table $\left.x\right|^{1-3}$ (Cont'd.)

\begin{tabular}{|c|c|c|c|c|}
\hline Bullding & Heating System & $\begin{array}{l}\text { Heating System } \\
\text { HW flow Rate } \\
\end{array}$ & $\begin{array}{ll}\text { Hot Water } & \text { No of Hot } \\
\text { Generator } & \text { Water Faucets }\end{array}$ & $\begin{array}{l}\text { DHW } \\
\text { Temp }\end{array}$ \\
\hline Baldwin Hall & Steam & $\begin{array}{l}\text { Steam } \\
\text { Radiators }\end{array}$ & Steam & \\
\hline Research Ctr & Steam & Live Steam & Steam & \\
\hline WRC & Steam & $210 \mathrm{GPM}$ & Steam & $131^{\circ}$ \\
\hline Garcia Dorm & Steam & $240 \mathrm{GPM}$ & 734 & $131^{\circ}$ \\
\hline R-G-H Dorms & Steam & $112 \mathrm{GPM}$ & steam & $131^{\circ}$ \\
\hline Branson Hall & Steam & $88 \mathrm{GPM}$ & steam & \\
\hline Computer Ctr & Steam & $112 \mathrm{GPM}$ & Steam & $130^{\circ}$ \\
\hline Activity ctr & Stean & $330 \mathrm{GPM}$ & Steam & $130^{\circ}$ \\
\hline Milton & Steam & $314 \mathrm{GPM}$ & Steam & $130^{\circ}$ \\
\hline Guthrie & Double Duct & $400 \mathrm{GPM}$ & Steam & $60^{\circ}$ \\
\hline Ha rdman & Steam & $224 \mathrm{GPM}$ & $\begin{array}{l}20 \text { (only 1'connected } \\
\text { in custodian's closet) }\end{array}$ & $\begin{array}{c}110^{\circ} \\
60\end{array}$ \\
\hline Ed. Services & $\begin{array}{l}\text { Double Duct } \\
\text { Steam }\end{array}$ & $50 \mathrm{GPM}$ & Steam & $131^{\circ}$ \\
\hline $\begin{array}{l}\text { Little } \\
\text { Theater }\end{array}$ & $\begin{array}{l}\text { Double Duct } \\
\text { Steam }\end{array}$ & Live Steam Coll & Steam & $90^{\circ}$ \\
\hline Corbett & $\begin{array}{l}\text { Double Duct } \\
\text { Steam }\end{array}$ & $400 \mathrm{GPM}$ & Steam & $131^{\circ}$ \\
\hline PSL & $\begin{array}{l}\text { Double Duct } \\
\text { Steam }\end{array}$ & $200 \mathrm{GPM}$ & Steam/Solar & \\
\hline
\end{tabular}




\section{Appendix A}

\section{NMSU GEOTHERMAL PRODUCTION WELLS \\ PUMP TEST ON NMSU-PG-3 AND \\ (January 24-26, 1981) \\ Report by \\ Lokesh Chaturvedi: \\ Conrad G. Keyes, Jr. \\ George A. Mitchell}

COMBINED PUMP TEST ON PG-1 AND PG-3

\section{Details of Tests:}

Figure $A-1$ shows the relative locations of the two NMSU geothermal production wells, PG-1 and PG-3 and the observation well 0 W-1. A series of pump tests were conducted during January 24 to 26,1981 to test the newly drilled well, PG-3, and to further define the characteristics of the Las Alturas geothermal aquifer. The tests consisted of the following stages:

- Well PG-3 was pumped from 6:15 a.m. to 9:00 p.m. on January 24. The pump was stopped to carry out surging and cleaning operation on the well. Drawdown measurements were taken in PG-1 and $O W-1$. Average rate of pumping was 200 gallons per minute.

- Well PG-3 was pumped again from 7:15 a.m. to 9:00 p.m. on January 25. Drawdown was recorded in $0 W-1$. Average rate of pumping was 200 gallons per minute.

- Wells PG-1 and PG-3 were pumped simultaneously for 16.5 hours, from $6: 15$ a.m. to $10: 30 \mathrm{p} . \mathrm{m}$. on January 26 . Drawdown in the observation well was recorded. Again, the average rate of pumping from each well was 200 gallons per minute.

- The temperature of water was $144^{\circ} \mathrm{F}$ from PG-3 and $142^{\circ} \mathrm{F}$ from PG-1. 


\section{Drawdown Data}

Table A-1 shows the drawdown in the observation well due to pumping of PW-3 on January 25. Table A-2 shows the drawdown in the observation well due to simultaneous pumping of $\mathrm{PW}-1$ and $\mathrm{PW}-3$ on January 26. Table A-3 shows the results of three different pump tests and the total drawdown produced in the observation well. The drawdown observations made in PG-1 were erratic due to equipment problems and have not been used.

\section{Aquifer Characteristics}

a. Copper-Jacob Method

Figure A-2 is a semilogarithmic plot of Drawdown vs. Time recorded on the observation well when PG-3 was pumped for 14 hours at approximately 200 gpm on January 25. The following calculations of $\mathrm{T}$ and $\mathrm{S}$ are made from this plot:

$$
\begin{aligned}
\Delta h & =1.26-(-0.5) \text { feet } \\
& =1.31 \text { feet } \\
T & =\frac{264 \theta}{\Delta h} \\
& =\frac{264 \times 200}{1.31} \\
& =\frac{40,305 \mathrm{gpd} / \mathrm{ft}}{(1031)^{2}} \\
S & =\frac{2.25 \mathrm{~T} \mathrm{to}}{\mathrm{r}^{2}} \\
& =\frac{2.25 \times 40,305 \times 120}{60 \times 24} \frac{0.134}{\left(\mathrm{~g} / \mathrm{ft}^{3}\right)} \\
& =\frac{0.00095}{\text { day } \left./ \mathrm{min}^{2}\right)}
\end{aligned}
$$


b. Theis Method

Figure A-2 is a U vs. W(u) type curve. Figure A-3 is a log-log plot of drawdown vs. $r^{2} / \tau$ using the values from Table $A-1$. The following calculations of $T$ and $S$ from this plot are:

Match Point Coordinates

$$
\begin{aligned}
h_{0}-h & =1 \mathrm{ft} . \\
r^{2} / \tau & =2 \times 10^{6}(\mathrm{ft} / \mathrm{day}) \\
u & =0.11 \\
w(u) & =1.7
\end{aligned}
$$

$$
\begin{aligned}
T & =\frac{114.6 \theta}{h--h} w(u) \\
S & =\frac{U T}{1.87 r^{2} / \tau} \\
T & =\frac{114.6 \times 200}{1} \times 1.7 \\
& =\frac{38,964 \mathrm{spd} / \mathrm{ft}}{1.87 \times 2 \times 106} \\
S & =\frac{0.11 \times 38,964}{10} \\
& =\frac{0.001146}{}
\end{aligned}
$$

\section{Discussion of Results}

Previous calculations of Transmissibility using drawdown rate in PG-1, recovery in $P G-1$, drawdown in $0 W-1$ and recovery in $0 W-1$, when only $P G-1$ was pumped, yielded results of $T=6000$ to $6500 \mathrm{gpd} / \mathrm{ft}$. Using those tests, $S=0.00971$ (See our Report of December 15-17, 1980 Test, Appendix B). 
The calculations above, using the observations in $0 W-1$ when $P G-3$ was pumped yields $T \quad 40,000 \mathrm{gpd} / \mathrm{ft}$ and $S=1.0001$. The calculations using Copper-Jacob method could be eroneous due to a large value of u resulting by using the Theis method. The shape of the curves obtained and the close correspondence between the results of two calculations indicates that the values obtained are most likely correct.

\section{Conclusions and Recommendations}

a. It appears that the Las Alturas Geothermal Aquifer has a better Transmissibility and still very good Storage Coefficient compared to estimates previously made. Using the pumping of PG-3 and observations made in $0 W-1,1031$ feet to the south, the latest tests show $T=40,000$ $\mathrm{gpd} / \mathrm{ft}$ and $\mathrm{S}=0.00115$.

b. The observation well is affected almost immediately when PG-1 (240 feet to the west) starts pumping. The total drawdown recorded in OW-1 due to the pumping of PG-1 was 13.75 feet (See Table A-3). However, it took about two hours of pumping PG-3 before $0 W-1$ was affected (1031) feet away) and the total drawdown recorded after 14 hours of pumping was only 1.08 feet. As a result of combined pumping of $P G-1$ and $P G-3$, the observation well showed a drawdown of 18.25 feet after 16.5 hours of pumping.

c. After a permanent pump is installed on PG-3, a properly controlled series of tests using the three wells should be run. The rate of discharge should be kept constant during a test, with minumum fluctuations and no interruptions. 

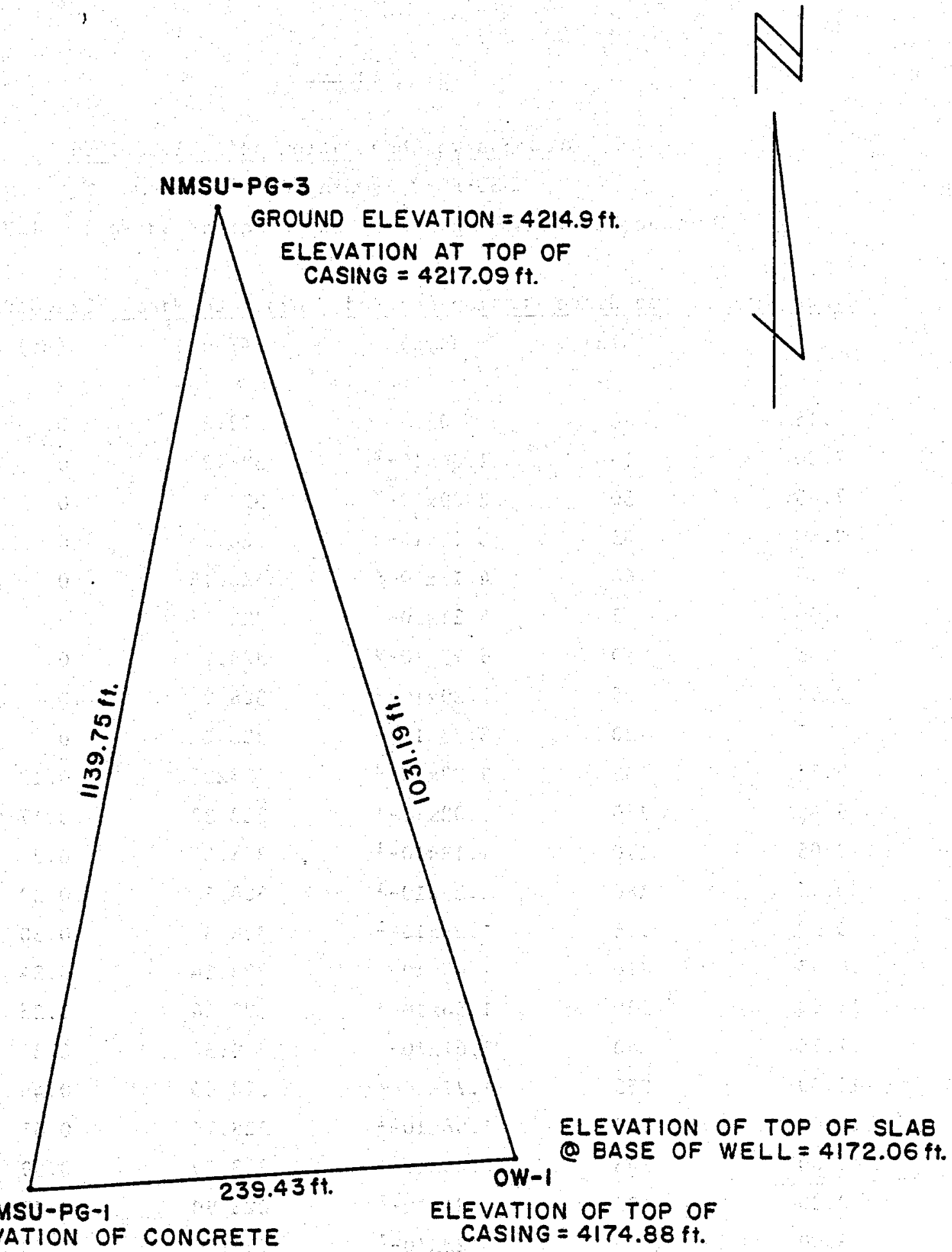

FLOOR NEXT TO PUMP $=4164.15 \mathrm{ft}$. 
Table A-1

Drawdown in Observation Well, 1.25.1981

$$
\text { NMSU-PG-3 Pumping at }=200 \mathrm{pgm}
$$

Distance Between Pumped Well and Observation Well = 1031 feet

$\frac{\text { Clock Time }}{\text { Time Since Pumping Started }}$ (Min) $\frac{\text { Depth to Water }}{\text { (deet) }} \frac{\text { Drawdown }}{(\mathrm{ft})} \frac{\mathrm{r}^{2} / \tau}{\left(\mathrm{ft} \mathrm{f}^{2} / \mathrm{day}\right)}$

\begin{tabular}{|c|c|c|c|c|c|}
\hline 7.15 & 0 & 0 & 328.2 & 0 & 0 \\
\hline 7.30 & 15 & $1.04 \times 10^{-2}$ & 328.2 & 0 & $1.02 \times 10^{8}$ \\
\hline 7.45 & 30 & $2.09 \times 10^{-2}$ & 328.2 & 0 & $5.07 \times 10^{7}$ \\
\hline 8.00 & 45 & $3.13 \times 10^{-2}$ & 328.16 & 0 . & $3.39 \times 10^{7}$ \\
\hline 8.15 & 60 & $4.17 \times 10^{-2}$ & 328.16 & 0 & $2.54 \times 10^{7}$ \\
\hline 8.30 & 75 & $5.21 \times 10-2$ & 328.16 & 0 & $2.03 \times 10^{7}$ \\
\hline 8.45 & 90 & $6.25 \times 10^{-2}$ & 328.2 & 0 & $1.70 \times 10^{7}$ \\
\hline 9.00 & 105 & $7.29 \times 10-2$ & 328.2 & 0 & $1.45 \times 10^{7}$ \\
\hline 9.15 & 120 & $8.33 \times 10^{-2}$ & 328.2 & 0 & $1.27 \times 10^{7}$ \\
\hline 9.30 & 135 & $9.38 \times 10^{-2}$ & $328 \times 33$ & 0.13 & $1.13 \times 10^{7}$ \\
\hline 9.45 & 150 & $1.02 \times 10^{-1}$ & 328.37 & 0.17 & $1.04 \times 10^{7}$ \\
\hline 10.05 & 170 & $1.18 \times 10^{-1}$ & 328.5 & 0.30 & $8.98 \times 10^{6}$ \\
\hline 10.15 & 180 & $1.25 \times 10^{-1}$ & 328.5 & 0.30 & $8.48 \times 10^{6}$ \\
\hline 0.30 & 195 & $1.35 \times 10^{-1}$ & 328.5 & 0.30 & $7.85 \times 10^{6}$ \\
\hline 10.45 & 210 & $1.46 \times 10^{-1}$ & 328.54 & 0.34 & $7.26 \times 10^{6}$ \\
\hline 11.00 & 225 & $1.56 \times 10^{-1}$ & 328.56 & 0.36 & $6.79 \times 10^{6}$ \\
\hline 11.15 & 240 & $1.67 \times 10^{-1}$ & 328.54 & 0.34 & $6.35 \times 10^{6}$ \\
\hline 11.30 & 255 & $1.77 \times 10^{-1}$ & 328.66 & 0.46 & $5.99 \times 10^{6}$ \\
\hline 12.00 & 285 & $1.98 \times 10^{-1}$ & 328.75 & 0.55 & $5.35 \times 10^{6}$ \\
\hline 1.00 & 345 & $2.40 \times 10^{-1}$ & 328.79 & 0.59 & $4.42 \times 10^{6}$ \\
\hline 2.00 & 405 & $2.81 \times 10^{-1}$ & 328.90 & 0.70 & $3.77 \times 10^{6}$ \\
\hline 3.00 & 465 & $3.23 \times 10^{-1}$ & 329.00 & 0.80 & $3.28 \times 10^{6}$ \\
\hline 4.00 & 525 & $3.65 \times 10^{-1}$ & 329.12 & 0.92 & $2.90 \times 10^{6}$ \\
\hline 5.00 & 585 & $4.06 \times 10^{-1}$ & 329.16 & 0.96 & $2.61 \times 10^{6}$ \\
\hline 6.00 & 645 & $4.48 \times 10^{-1}$ & 329.21 & 1.01 & $2.37 \times 10^{6}$ \\
\hline 7.00 & 705 & $4.90 \times 10^{-1}$ & 239.21 & 1.01 & $2.16 \times 10^{6}$ \\
\hline 8.00 & 765 & $5.31 \times 10^{-1}$ & 329.21 & 1.01 & $2.00 \times 10^{6}$ \\
\hline 9.00 & 825 & $5.73 \times 10^{-1}$ & 329.25 & 1.05 & $1.85 \times 10^{6}$ \\
\hline
\end{tabular}


Table A-2

Drawdown in Observation Well, 1.26 .1981

NMSU-PG-1 and PG-3 Pumping at $=200 \mathrm{gpm}$

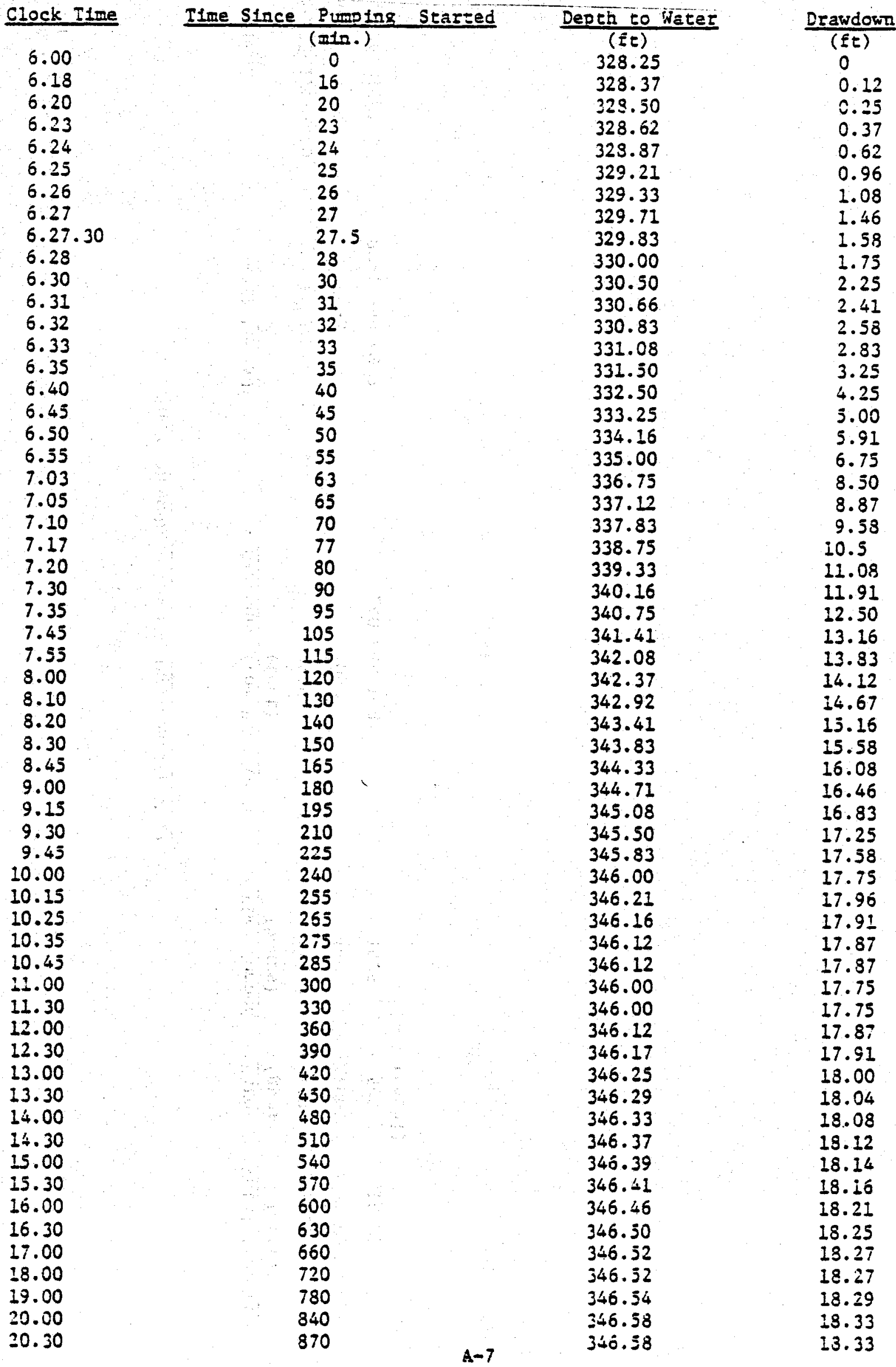


Tab1e A-3

Tota1 Drawdowns in the Observation We11

\section{Date}

Dec 15-17, 1980

Jan 25, 1981

Jan 26, 1981
We11 Pumped

PG-1

PG-3

PW-1 and PW-3

Distance from P.W. to O.W.
(feet)
240
1031
240 and 1031

$\frac{\text { Time Pumped }}{\text { (hours) }}$

44

14

16.5

240 and 1031 $\frac{\text { Rate }}{\text { (gpm) }} \quad \frac{\text { Tota1 Drawdown }}{\text { (feet) }}$

$-149 \quad 13.75$

$=200 \quad 1.08$

$=400 \quad 18.25$

(tota1) 


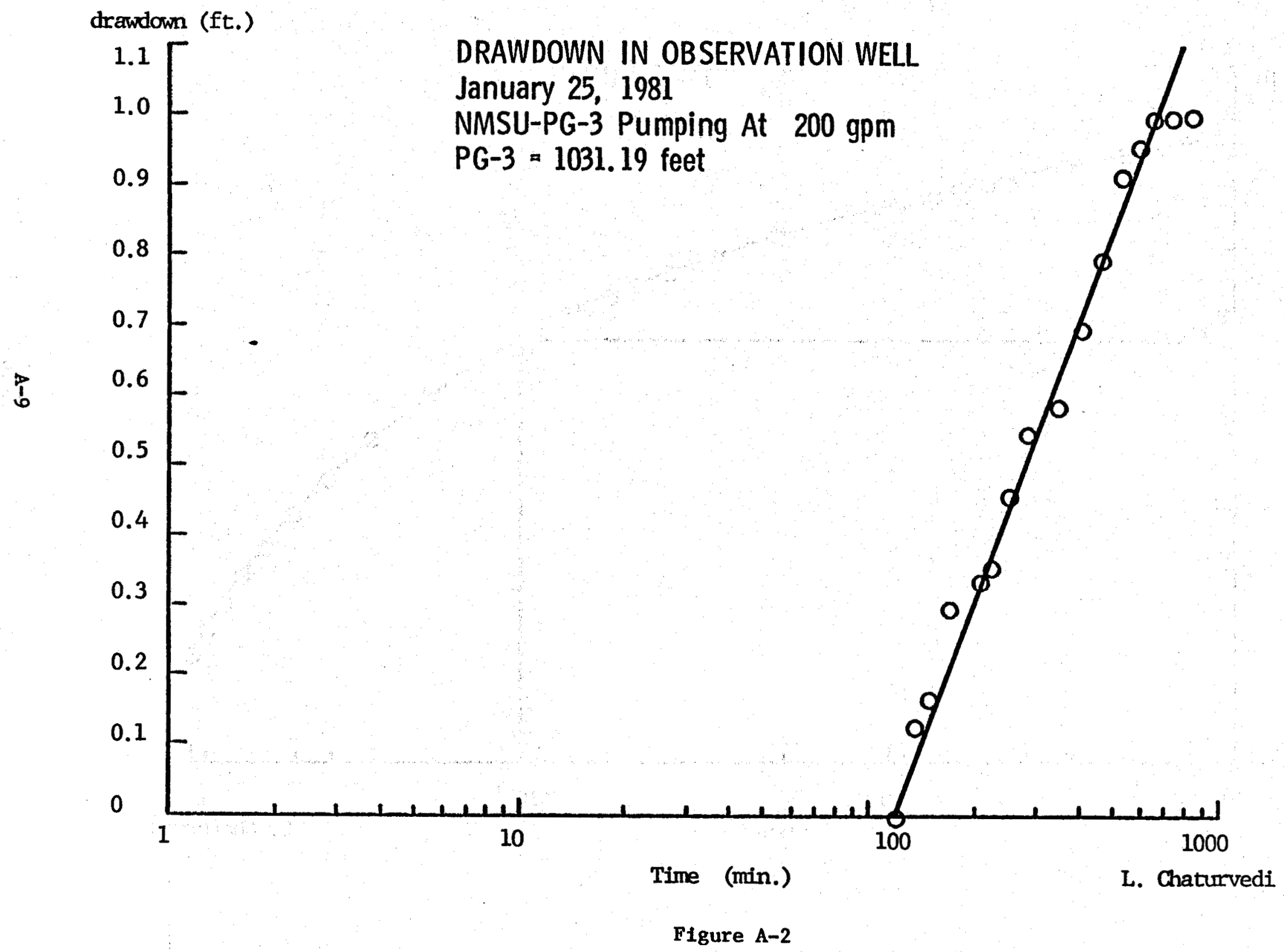




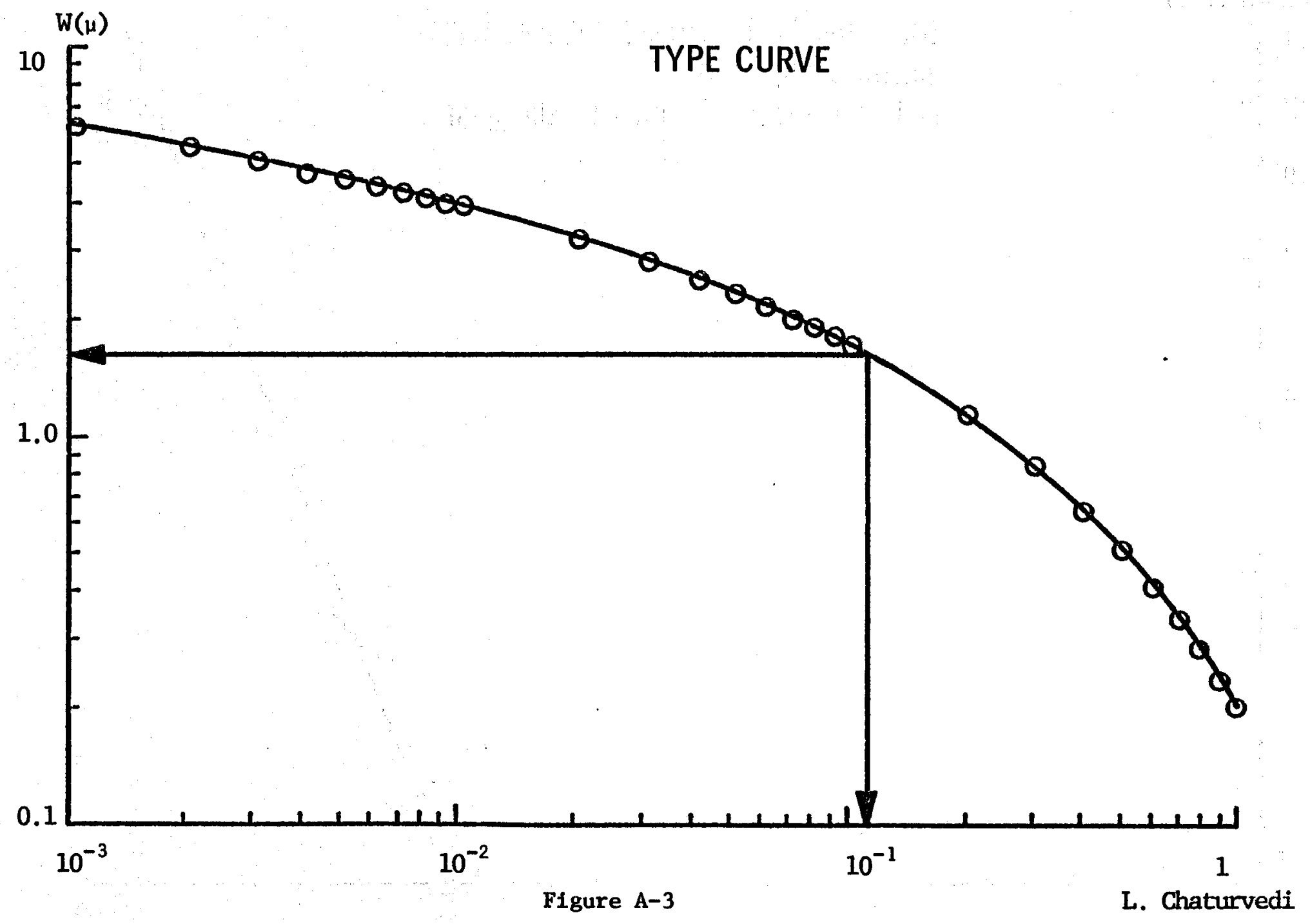




\section{DRAWDOWN IN OBSERVATION WELL}

January 25,1981

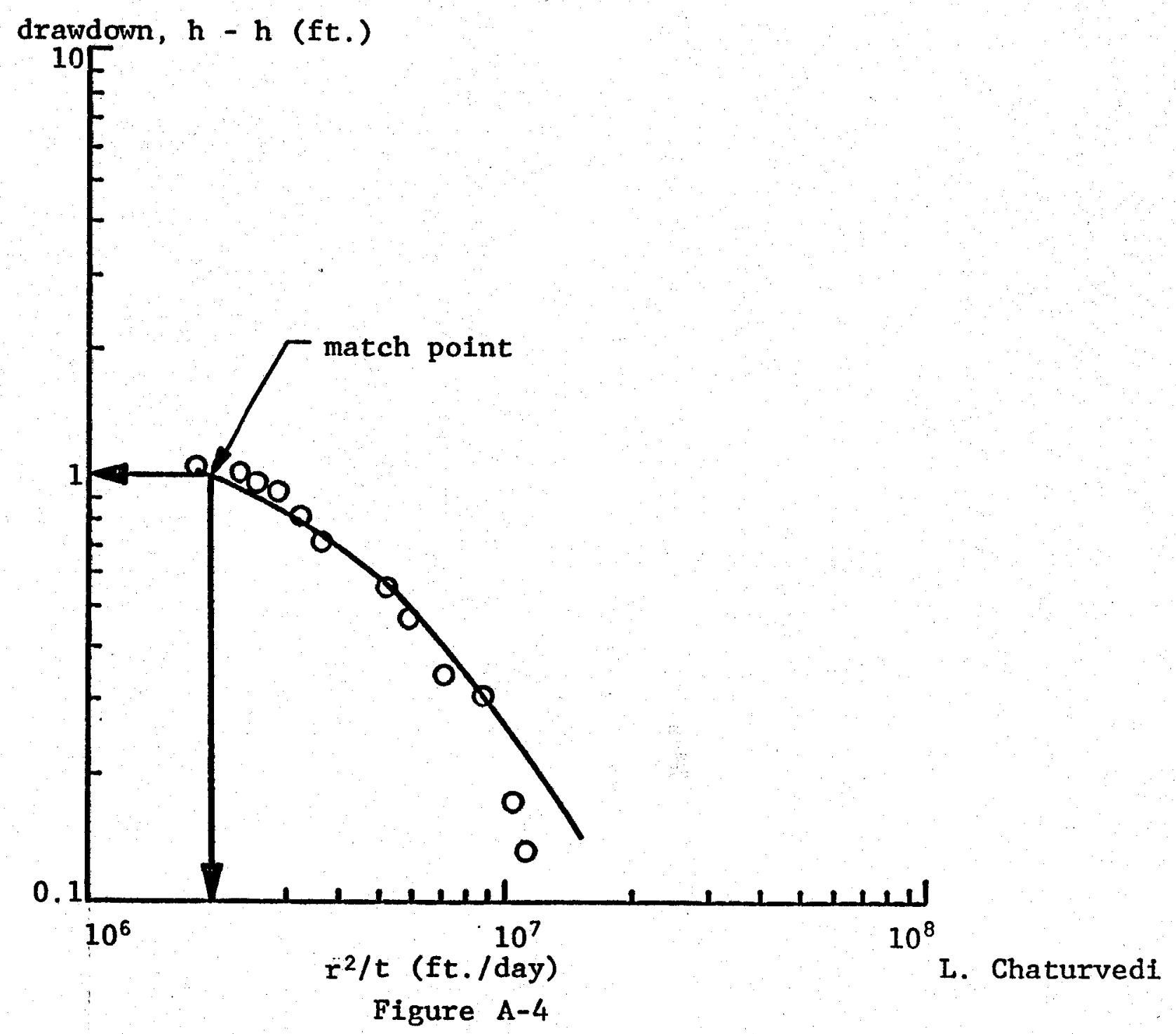


Appendix B

Report of

NEW MEXICO STATE UNIVERSITY GEOTHERMAL PRODUCTION WELL FORTY-EIGHT HOUR PUMP TEST

by

\author{
George A. Mitchel1 \\ Lokesh Chaturvedi \\ Conrad G. Keyes, Jr. \\ Jeffrey K. Lory
}

\title{
1. Purpose of Test
}

The purpose of this test was to obtain additional information on the aquifer characteristics and data to select a site for a second geothermal production well without interference between the two wells.

\section{Background}

The test was conducted using the same 50 h.p. surface driven Peerless pump with 17 turbine stages that was used during the test of this well conducted 12-21 July 1980. The presence of gas in the water discharged from the well was noted at the end of the July test. The pump was pulled from the well in early November 1980. An observation we11 was drilled 240 feet east of the production well in November 1980. Both pump and motor were torn down and inspected. No mechanical deficiencies were found. A down-hole gas separator was installed and the pump and motor were reinstalled in early December 1980 . The tops of the bowls were again set at 600 feet.

After reinstallation tests of the pump and motor, the aqu'fer was not disturbed for a period of 72 hours before starting the 48-hour test. 


\section{Details of the Test}

The test was planned for a 48-hour duration or a minimum of six hours after a stable level of drawdown was reached. The test started at 2:10 p.m., December 15, 1980 and completed at 10:30 a.m., December 17, 1980. The pump was operated at a steady pumping rate of about 149 gallons per minute (gpm) throughout the test. The observed fluctuations were 148-152 8pm. The temperature of the water at the surface was $141^{\circ} \mathrm{F}$ (range $140-$ $\left.142^{\circ} \mathrm{F}\right)$.

Static water level in the production well before and after the pumping test was 324 feet below the collar. Static water level in the observation well was 327 feet below the collar elevation.

Drawdown in both wells stabilized after the production well had been pumped for about 24 hours. Drawdown in the production well stabilized at 114 feet. Drawdown in the observation well stabilized at 13.8 feet. Tables B-1 and B-2 show the time vs. drawdown data for both wells.

Flow was measured with a three-inch turbine flow meter with a direct digital readout and a pen recorder. The meter was calibrated prior to test commencement. During the test, accuracy was checked by timing the filling of a measured tank.

Temperature was recorded continuously as well as manually monitored at regular intervals. 
The water flow from this test was discharged into an arroyo adjacent to the well. A series of four earth check dams were constructed to prevent flow of the water from NMSU property. The water was essentially contained within the first two check dams with only a trickle from the overflow of the second dam.

After completion of pumping, the aquifer water level recovery was monitored for four days. The static water level of 324 feet for the production well was almost completely reestablished about $5 \frac{1}{2}$ hours after pumping stopped. Static water level of approximately 327 feet was reestablished after about six hours at the observation well.

\section{Conclusions}

a. The drawdown vs. time was plotted on semilogarithmic paper for both the pumped well and the observation well (Figures B-1 and B-2). The initial drawdown data for the pumped well indicates an aquifer transmissibility, $T$, equal to about 6,215 gallons per day per square foot (gpd/ft). Data from the observation well indicates $\mathrm{T}=6,500 \mathrm{gpd} / \mathrm{ft}$.

b. Based on the effect of pumped well on the observation well, it is recommended that the second production well should be at least 1,000 feet away from the first production well. 
Pump Test Data (December 15-17, 1980) Drawdown in PG-1

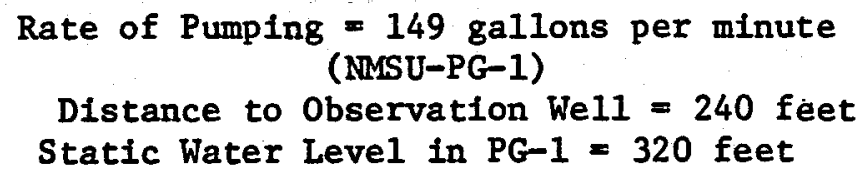

(min.)

(feet) $\quad$ (feet)

\section{CLOCK TIME}

TIME SINCE PUMPING BEGAN

DEPTH TO WATERLEVEL DRAWDOWN

$12 / 15$

$\begin{array}{rr}1410 & -0- \\ 1412 & 2 \\ 1415 & 5 \\ 1420 & 10 \\ 1430 & 20 \\ 1442 & 32 \\ 1457 & 47 \\ 1510 & 60 \\ 1614 & 124 \\ 1707 & 177 \\ 1820 & 250 \\ 1920 & 310 \\ 2230 & 500 \\ 0220 & 730 \\ 0640 & 990 \\ 0825 & 1095 \\ 1030 & 1220 \\ 1420 & 1450 \\ 1800 & 1670 \\ 2200 & 1910 \\ 0610 & 2400 \\ 0950 & 2740\end{array}$

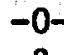

5

455

135

10

430

110

20

420

100

47

422

102

424

425

104

124

427

105

107

428

108

429

429.5

109

310

430

109.5

730

435.08

110

435.17

115.08

432.58

115.17

433.25

112.58

434.5

113.25

433.0

114.5

113.0

433.75

434.0

113.75

114.0

$\begin{array}{ll}12 / 17 & 0610 \\ & 0950\end{array}$

434.25

114.25

$$
\begin{gathered}
\Delta h=h_{0}-h=112.33-106.0=6.33 \mathrm{ft} . \\
T=\frac{264 \times 149}{6.33}=6214.22 \mathrm{gpd} / \mathrm{ft} \\
S=\frac{0.3(6214.22)(0.3)}{(240)^{2}}=0.00971
\end{gathered}
$$




\section{Pump Test Data (December 15-17, 1980) Drawdown In Observation We11 \\ Distance from Pumped Well $=240 \mathrm{ft}$. \\ Static Water Leve1 $=326.58 \mathrm{ft}$. Below the Collar}

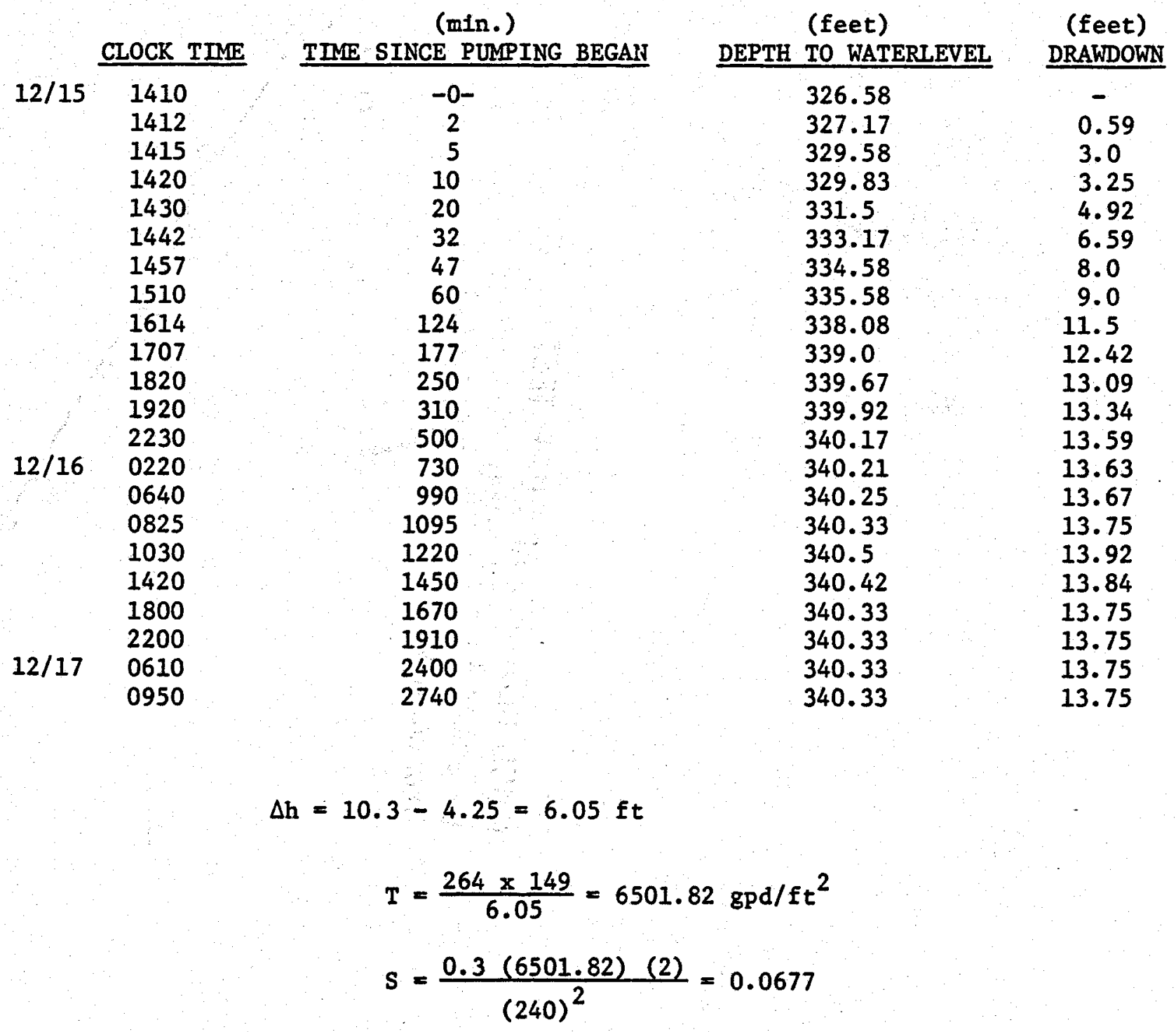




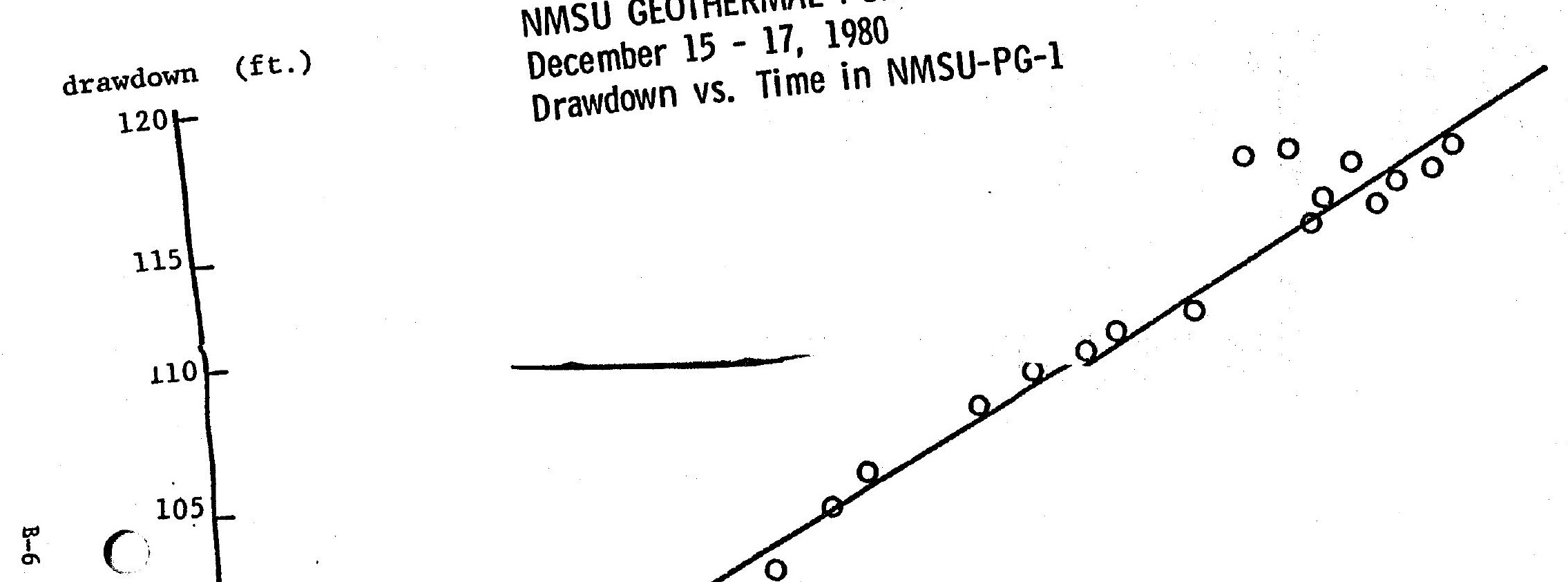




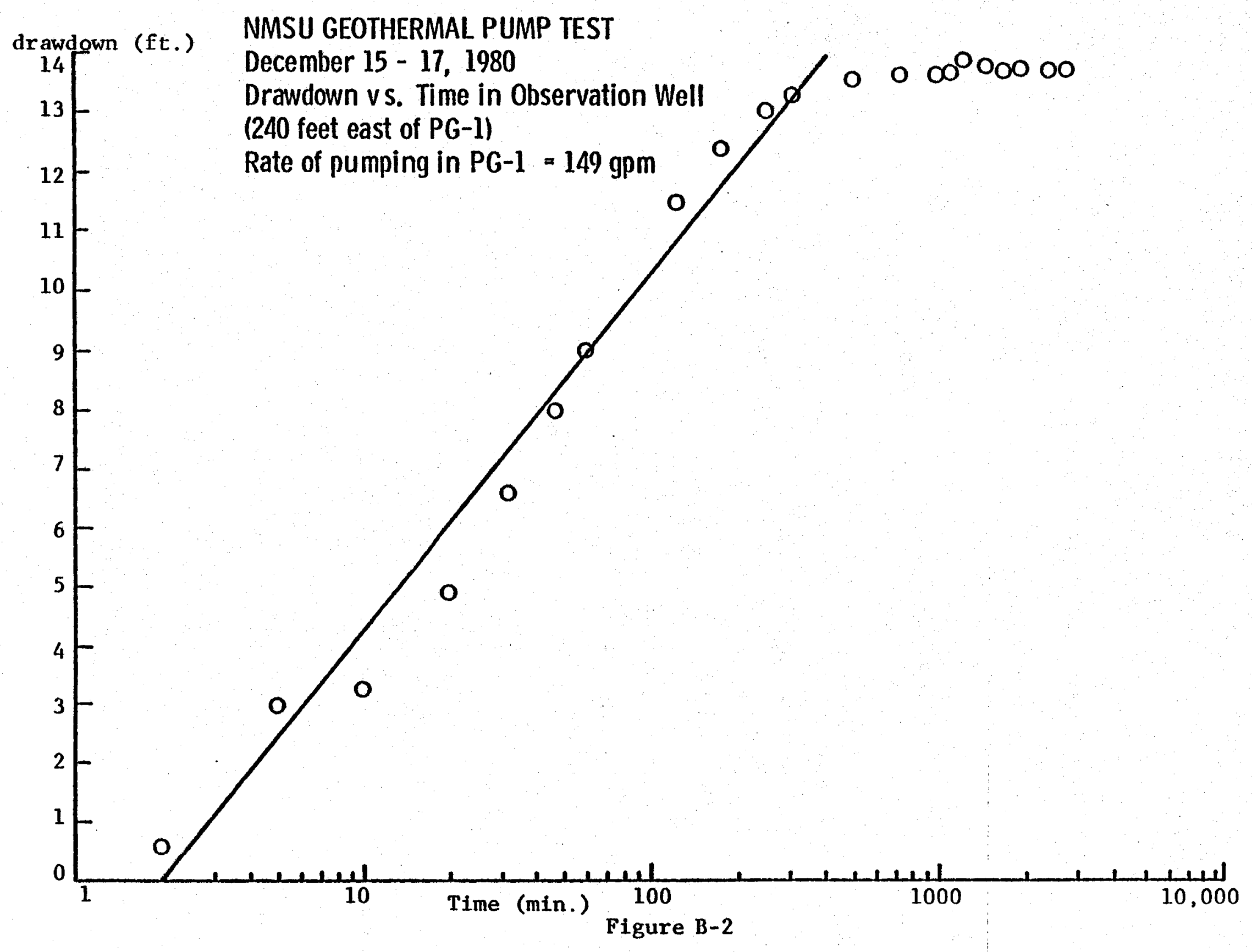


Appendix C

\section{PUMP PERFORMANCE}

The 50Hp Peerless Geothermal pump purchased for use in PG-1 required extensive testing for its performance due to the lack of information on pumping of geothermal water in the Southern New Mexico area. Performence factors selected for study included overall effect of the geothermal water on the pump, pumping pressures and capabilities. After installation of the pump, the field tests began.

The pump was field checked after electricity service was installed on 8 July 1980. These checks were performed under the supervision of Tom Yates, representing the supplier, Alpha Southwest of Albuquerque, New Mexico. Start-up and shut-down procedures were checked, and the time delay safety switch was set at 4.5 minutes. This allows the column of water to drain before the pump can be restarted.

On subsequent days, 9,10 , and $11 \mathrm{July} 1980$, the pump was operated for brief periods to check the instrumentation and surface connections for leaks. Temperature probes were installed to monitor motor housing, pump house, and ambient air temperatures to assure that pump motor temperatures did not exceed the allowable spectfications, which were defined as not more than $45^{\circ} \mathrm{C}$ higher than ambient eir temperatures.

A data collection scheme was devised to acquire data on pump performence, as well as aqvifer evaluation, during the eight to ten day continuous purping test. Key data included hourly recording of motor temperature, 
pump house temperature, ambient air temperature, surface pressure upstream and downstream from the turbine flowmeter, oil gauge, and oil line status. In addition, a continuous record was maintained of geothermal fluid flow rate and temperature using a strip chart recorder, with a visual display also using a digital counter.

The test was started formally at 0900 hours, $12 \mathrm{July} 1980$, and terminated at 1530 hours, 21 July 1980. Flow was varied between 200, 150, and 223 gpm, and a temperature of $141-142^{\circ} \mathrm{F}$ was experienced continuously. Details and observations worthy of mention follows.

On July 12, 1980 at 1530 hours, a noticeable vibration started in the pump. This vibration steadily increased, and as a precaution, at 1930 hours, a stethoscope was used to monitor motor bearings. A noticeable high-pitched noise was detected in the lower motor bearing, and visual observation of the grease fitting indicated the bearing lacked lubrication. Using the stethoscope to monitor the noise, a small amount of Quaker State Multilube lubricant was pumped in, just sufficient to quiet the noise. The vibration also perceptibly lessened, although it did not disappear. The stethoscope was used periodically the next several days, and $e$ slight roughness remained, but no high-pitched sound was detected. It was also noted that at 1930 hours on $12 \mathrm{July}$, the pump motor temperature had increased to $26^{\circ} \mathrm{C}$ higher than ambient air; so a blower fan was positioned to direct ambient air across the motor. The temperature difference dropped to $20^{\circ} \mathrm{C}$ and remained below that level for the balance of the 9.5 day test. 
Drawndown depth, flow and fluid heat, during the entire test were also measured. The total drawdown depth stabilized at approximately 501 feet through the first 24 hours of the test, then re-stabilized at 482 feet. Constant flow of $200 \mathrm{gpm}$ was maintained over the total of 96 hours. During the period, the fluid heat at the pump discharge declined steadily from an initial value of 32 psig to 27.5 psig.

At 0640 hours on $16 \mathrm{July}$, a temporary power flicker stopped the pump. Power was off for roughly two seconds; the automatic pump cutoff switch then shut down the pump. The pump was restarted at 0705 hours, and pumping continued at $200 \mathrm{gpm}$ unt 111200 hours. Drawdown depth was 482 feet, and pump discharge pressure was $26.0 \mathrm{psig}$.

At 1230, $16 \mathrm{July} 1980$, the flow was increased to pump maximum, which proved to be $223 \mathrm{gpm}$. Flow was maintained at this rate for 75 hours, until 1530 hours on 19 July. Drawdown depth was stable at 482 feet. At that draw-down, the pump performance curve indicates the pump could have delivered $290 \mathrm{gpm}$. From preliminary transmissivity data, the well should be capable of producing approximately 260 to $275 \mathrm{gpm}$ at a drawdown depth of 550 feet; whereas the pump performance curve indicates at least $250 \mathrm{gpm}$ at 550 feet of draw-down. Thus, the pump performance was a minimum of 27 gpm below specifications, with a probable deviative of up to $48 \mathrm{gpm}$.

At a flow rate of $155 \mathrm{gpm}$, and drawdown depth of 431 feet, the pump discharge pressure was $70 \mathrm{psig}$. This is equivalent to field head of 600 feet, which is within pump specifications for a flow of $200 \mathrm{gpm}$. Thus, the pump was performing approximately $25 \%$ below manufacturers specificaticns. 
At 1230 on $20 \mathrm{July}$, flow rate was increased to $199 \mathrm{gpm}$, and drawdown depth stabilized at 463 feet. Pump outlet pressure decreased steadily to 26.0 psig shortly before the test was terminated.

With Tom Yates of Alpha Southwest present, a shut-in test was conducted at 1530 hours on $21 \mathrm{July}$ in two stages. Initially, the flow was gradually reduced to attain pump discharge pressure of $42 \mathrm{psig}$, which is the specified outlet pressure at a flow of $200 \mathrm{gpm}$ and drawdown of 485 feet. At that pressure, the pump was able to deliver only $151 \mathrm{gpm}$. A complete shut-in was then conducted, and flow was shut off while the pump continued to run. Maximum pump discharge pressure fluctuated between 70 and 90 psig, whereas discharge pressure should have been approximately 106 psig at static water level of roughly 323 feet. The pump was then turned off at 1545 hours on 21 July 1980.

Overall, the pump performance was disappointing. However, an analys is of the pump performance data, in comparison to pump specifications and performance curves and observations of the geothermal water discharge revealed that the poor pump performance possibly could be attributed to gas contained in the geothermal fluid. Accordingly, a gas trap was fabricated and installed on the discharge line. This gas trap was used to collect gas samples under carefully controlled conditions. These samples were analyzed by gas chromatograph and a mass spectrometer, and both analyses indicated the presence of carbon dioxide and nitrogen. (See Section VI, Gas Separator). 


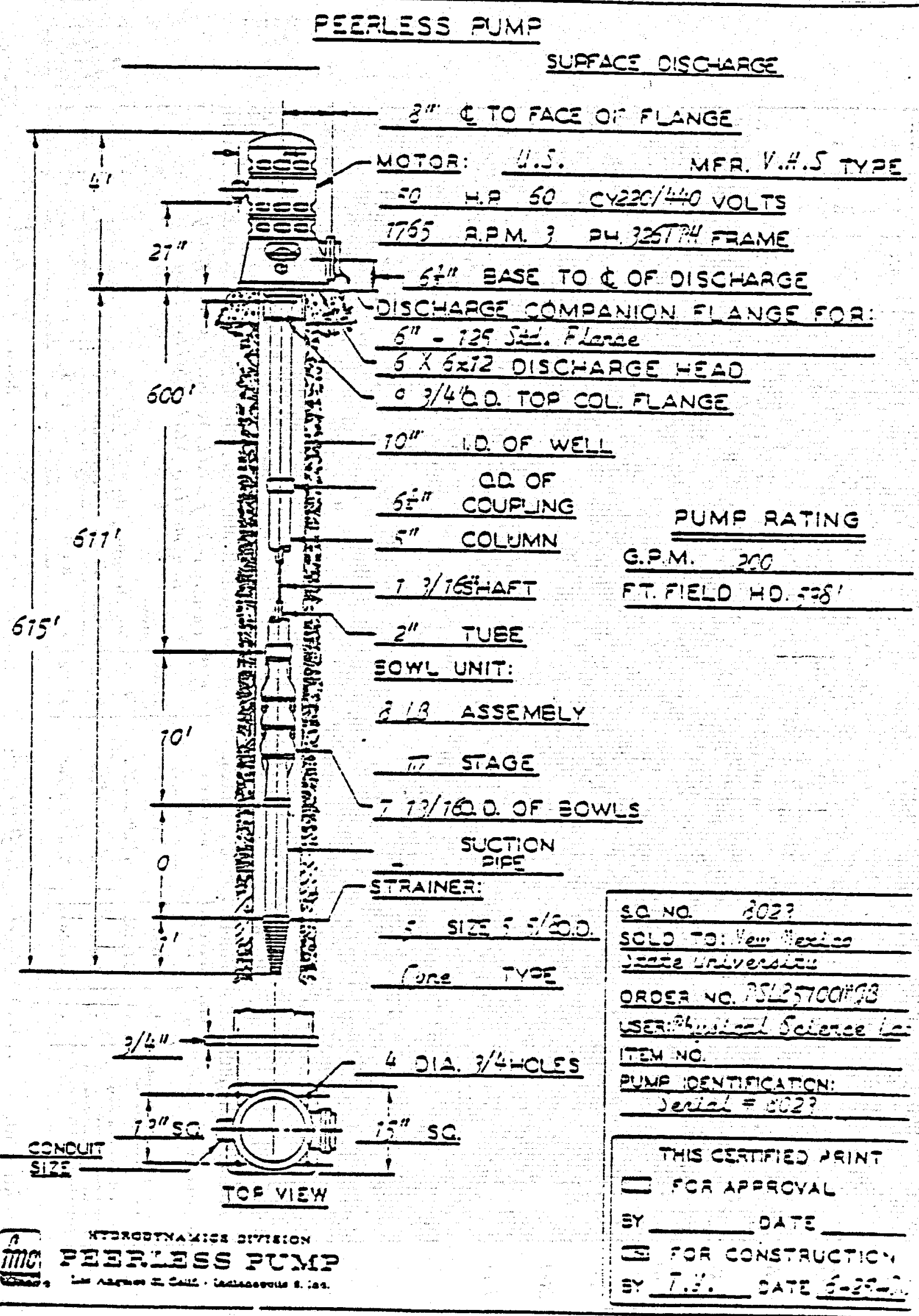

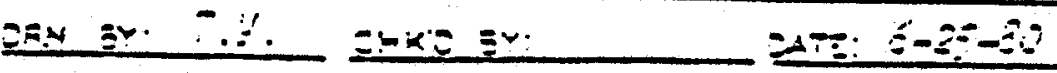




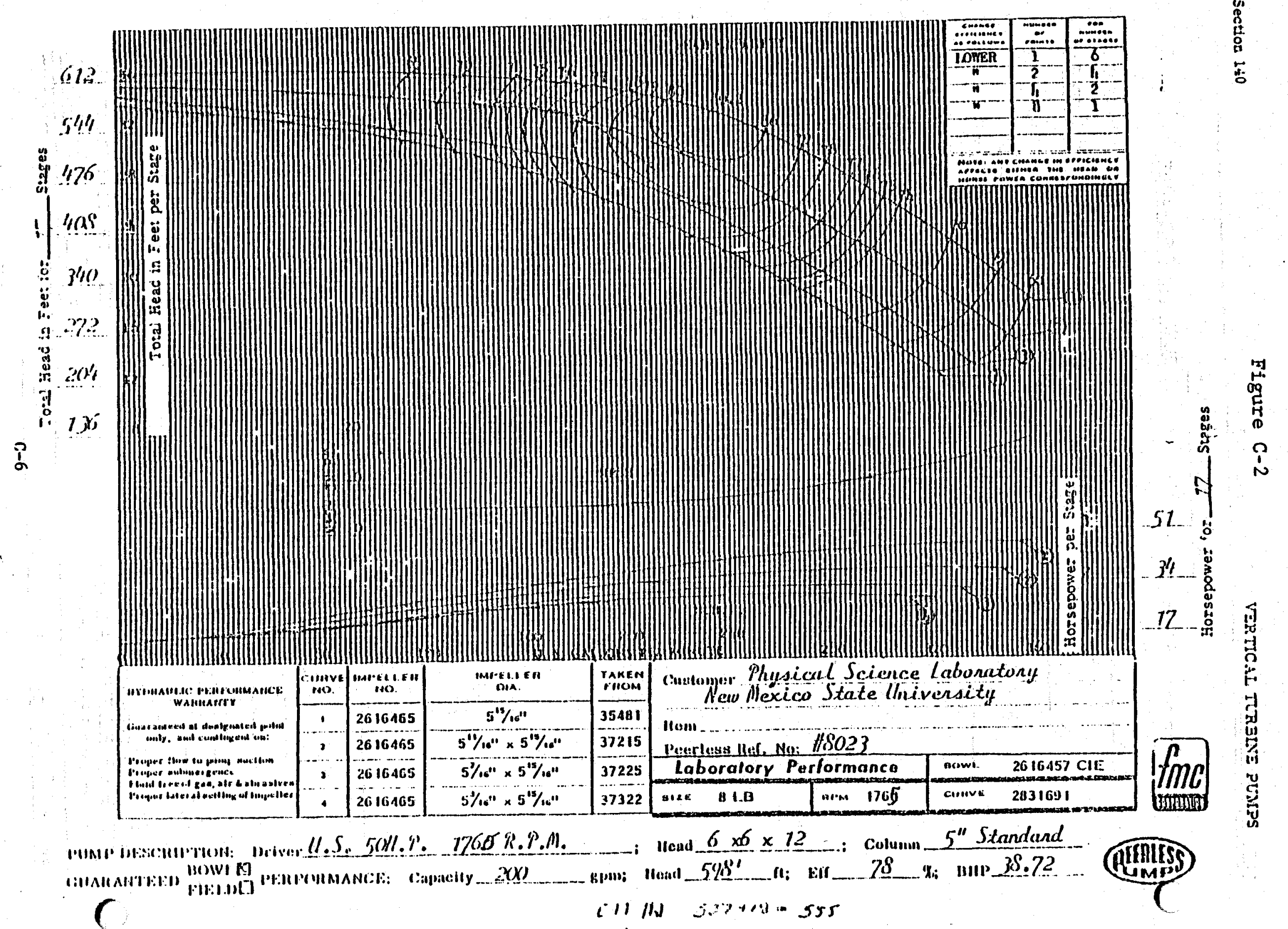

